
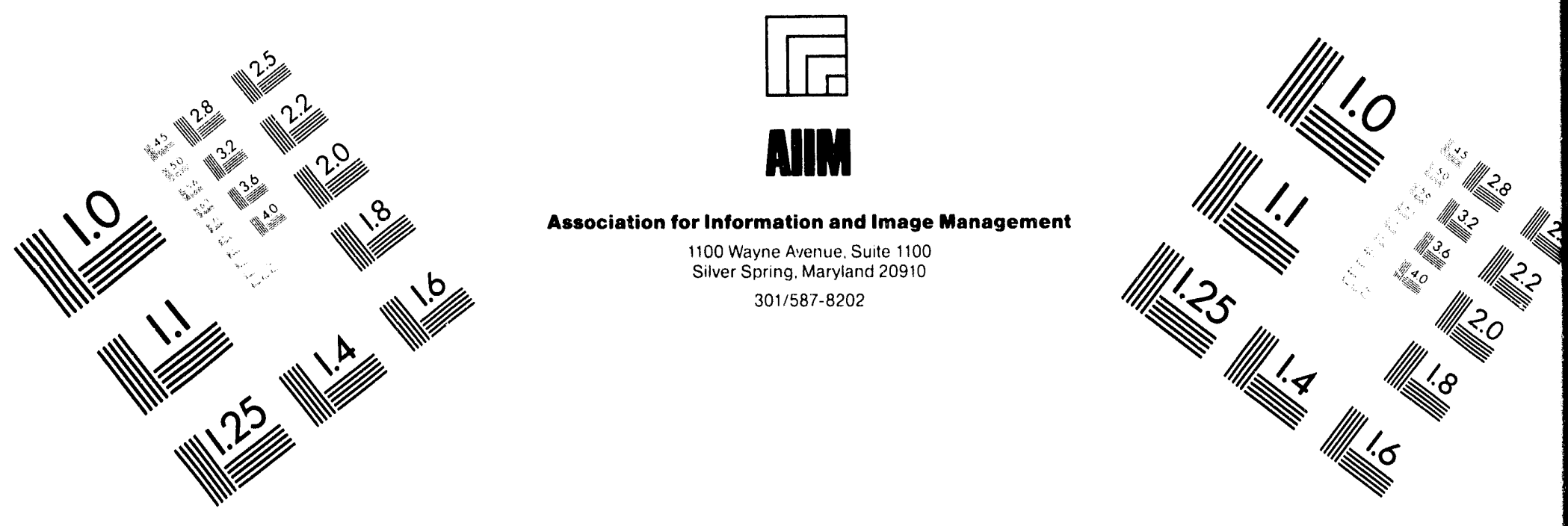

\title{
Centimeter
}

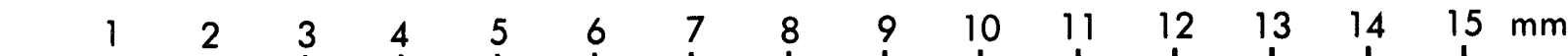

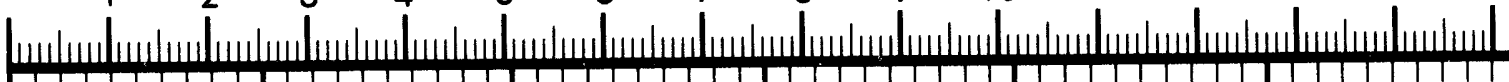

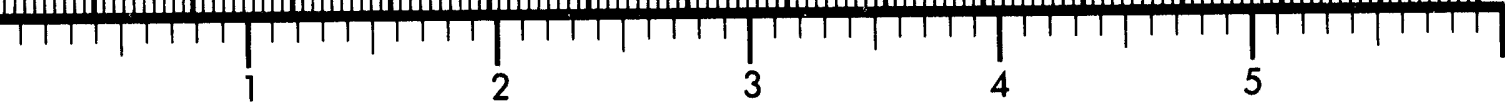
Inches
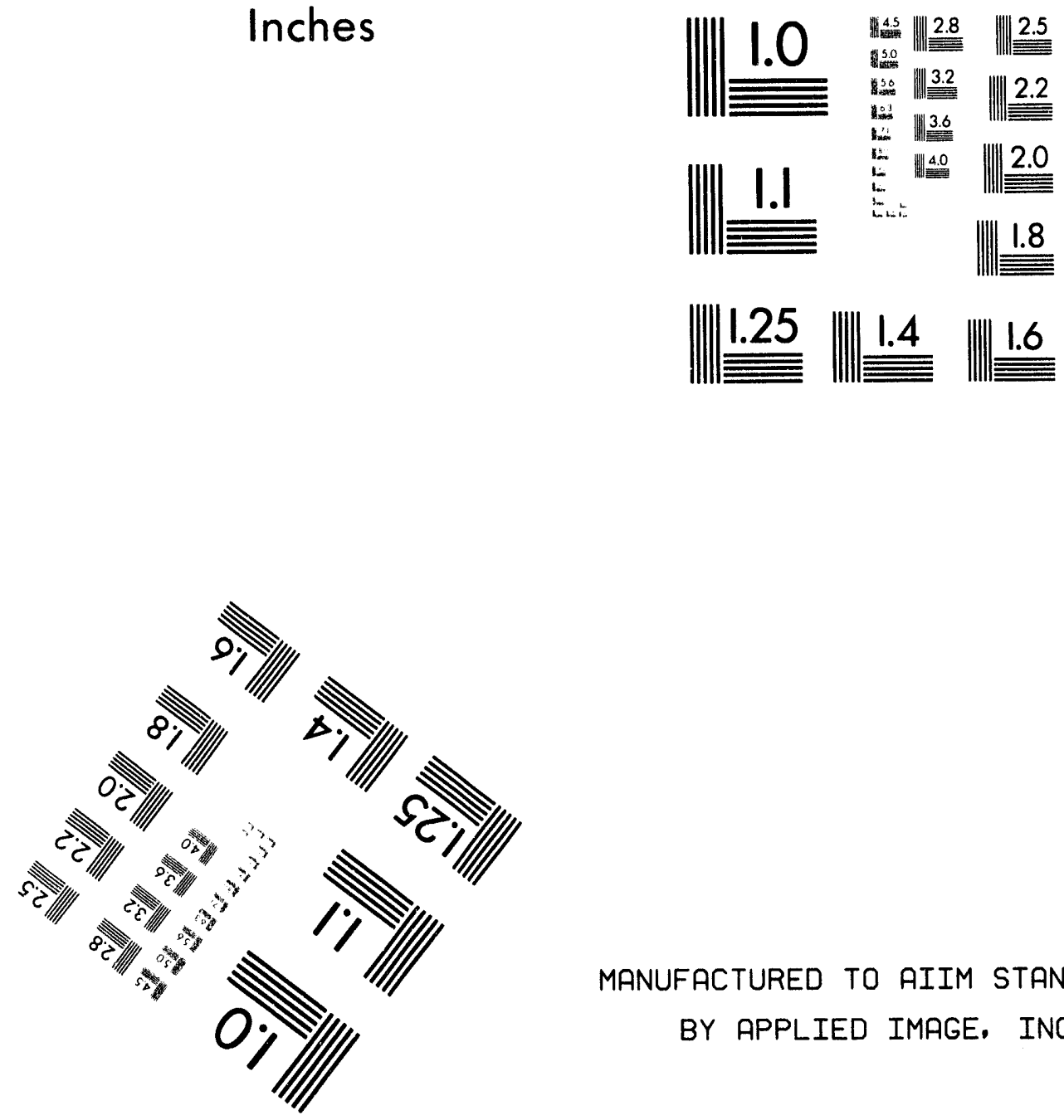

MANUFACTURED TO AIIM STANDARDS

BY APPLIED IMAGE, INC.

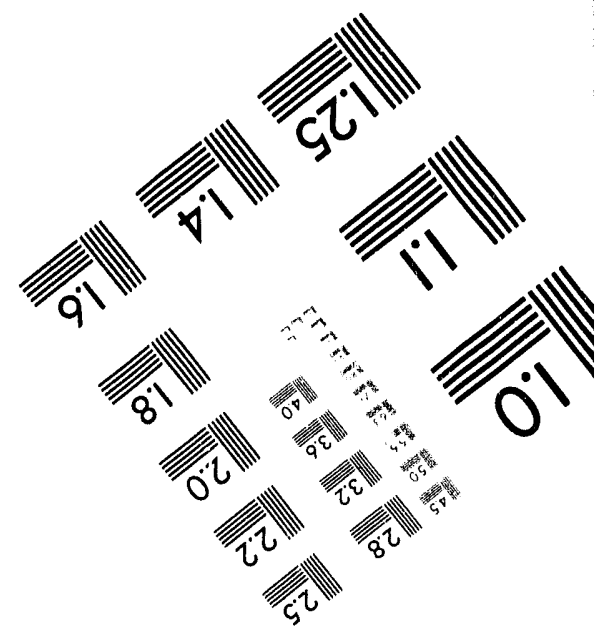



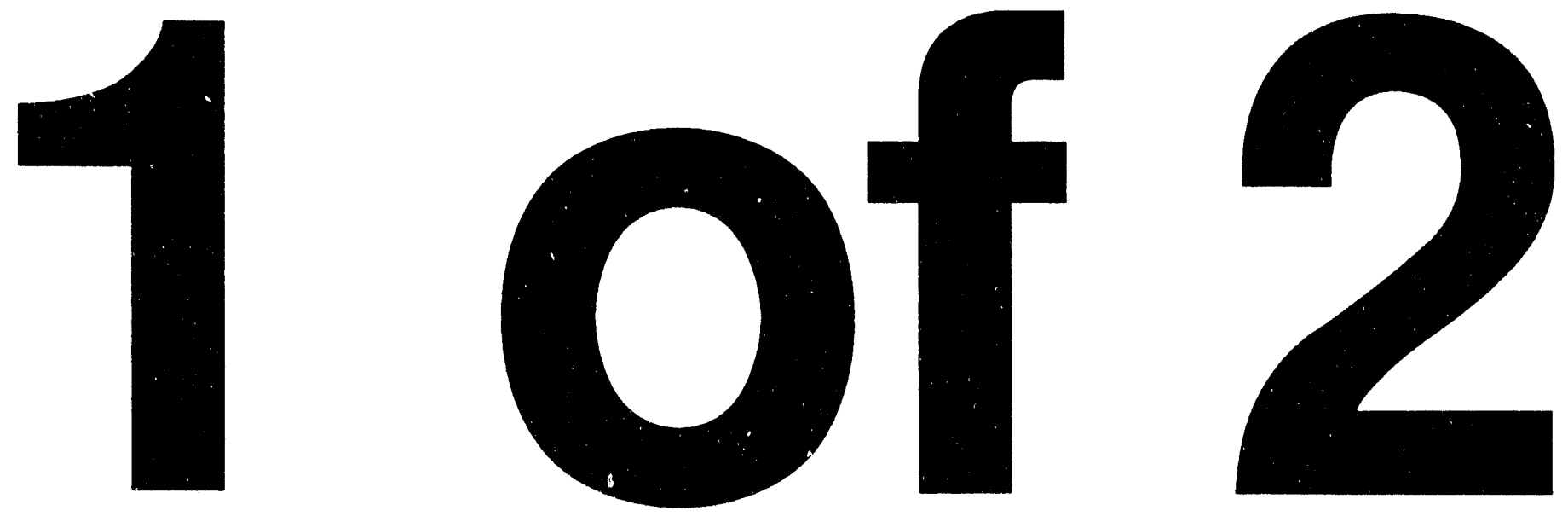


\section{Anaylsis of Deep Seismic Reflection and Other Data from the Southern Washington Cascades}

\section{Final Report}

September 15, 1992 - December 31, 1993

W. D. Stanley

S. Y. Johnson

V. F. Nuccio

December 1993

Work Performed Under Contract No.: DE-AT21-92MC29267

For

U.S. Department of Energy

Office of Fossil Energy

Morgantown Energy Technology Center

Morgantown, West Virginia

By

Interior Department of Geological Survey

Denver, Colorado 


\section{DISCLAIMER}

This report was prepared as an account of work sponsored by an agency of the United States Govemment. Neither the United States Govemment nor any agency thereof, nor any of their employees, makes any warranty, express or implied, or assumes any legal liability or responsibility for the accuracy, completeness, or usefulness of any information, apparatus, prochuct, or process disclosed, or represents that its use would not infringe privately owned rights. Reference herein to any specific commercial product, process, or service by trade name, trademark, manufacturer, or otherwise does not necessarily constiutte or imply its endorsement, recommendation, or favoring by the United States Covemment $o$ any agency thereof. The views and opinions of authors expressed herein do not necessarily state or reflect those of the United States Govemment or any agency thereof.

This report has been reproduced directly from the best available copy.

Available to DOE and DOE contractors from the Office of Scientific and Technical Information, P.O. Box 62, Oak Ridge, TN 37831; prices available from (615) 576-8401.

Available to the public from the National Technical Information Service, U.S. Department of Commerce, 5285 Port Royal Rd., Springfield, VA 22!61, (703) $487-4650$. 


\title{
Anaylsis of Deep Seismic Reflection and Other Data from the Southern Washington Cascades
}

\section{Final Report}

September 15, 1992 - December 31, 1993

\author{
W. D. Stanley \\ S. Y. Johnson \\ V. F. Nuccio
}

Work Performed Under Contract No.: DE-AT21-92MC29267

\author{
For \\ U.S. Department of Energy \\ Office of Fossil Energy \\ Morgantown Energy Technology Center \\ P.0. Box 880 \\ Morgantown, West Virginia 26507-0880 \\ By \\ Interior Department of Geological Survey \\ Box 25046 \\ Denver, Colorado 80225
}

December 1993 


\section{Table of Contents}

List of Illustrations 2

Preface $\quad 3$

Executive Summary $\quad 3$

Introduction 5

Geological-Tectonic Setting $\quad 8$

$\begin{array}{ll}\text { Chehalis Basin } & 14\end{array}$

Magnetotelluric Results $\quad 19$

Gravity and Magnetic Data $\quad 21$

Lithology of Rocks in the SWCC $\quad 22$

Seismic Reflection Data 26

Seismicity and Strike-Slip Faults $\quad 35$

Tectonic Models: Subduction or Pull-Apart $\quad 38$

Morton Antiform Stratigraphy and Sedimentology 41

What Rocks Underlie the Morton Antiform? 47

Morton Antiform Hydrocarbon Play 49

Summary and Conclusions $\quad 52$

Acknowledgments $\quad 53$

References $\quad 54$

Appendix A-Stratigraphic section and vitrinite reflectance data A1-A52

Appendix B.Shotpoint and velocity information $\quad$ B1-B27

Appendix C-MT and Seismic Physical Properties C1.C3

Appendix D.Details of the Magnetotelluric Method Di.D3 
List of Illustrations

Figure $1\left(p .4 f^{*}\right) \cdot$ Index map of western Washington and northwestern Oregon with seismic profiles.

Figure 2(p.6f)-Simplified geological map for western Washington.

Figure 3(p.9f)-Detailed geological map for SWCC region with seismic reflection shotpoints and MT profiles.

Figure 4(p.9ff)-Index geological map for the Chehalis Basin with three interpretive transects.

Figure 5(p. 13f)-Stratigraphic correlation chart for southwestern. Washington.

Figure 6(p. 13ff)-Stratigraphic section for profile AA', Chehalis Basin.

Figure 7(p. 15f)-Stratigraphic section for profile BB', Chehalis Basin.

Figure 8(p. 16f)-Stratigraphic section for profile CC', Chehalis Basin.

Figure 8(p. 16ff)-Seismic reflection section for DOE line 4.

Figure 10(p.17f)-Details of reflection data from line 4 near interpreted faults.

figure 11(p. 18f)-Computer models for MT profiles $A A^{\prime}, B^{\prime}, C^{\prime}$.

figure 12(p. 19f)-Model for MT profile EE'.

Figure 13(p. 20f)-High-resolution aeromagnetic map for SWCC region.

Figure 14(p. 20ff)-Aeromagnetic profile across the SWCC with geological section.

Figure 15(p. 29f)-Combined sonic log, stacking velocity, shale velocity/depth curve for velocity analysis.

Figure 16(p. 31f)-Seismic reflection section for DOE lines 1 and 2.

Figure 17(p. 32f)-Details of portion of seismic lines 1 and 2, Morton antiform.

Figure 18(p. 32ff)-Seismic reflection section for DOE line 3.

Figure 19(p.33f)-Detail of DOE line 3, east end.

Figure 20/p. 33ff)-Detail of portion of seismic line 3 near interpreted thrust fault.

Figure 21(p.34f)-Seismic reflection section for DOE line 5.

Figure 22(p. 34ff)-Seismic reflection section for DOE line 6.

Figure 23(p. 35f)-Seismicity for SWCC/Puget Sound region with interpreted strike-slip zones.

Figure 24(p. 36f)-MT model across Carbon River antiform.

Figure 25(p. 36ff)-Seismic reflection data from Carbon River antiform.

Figure 26(p. 36fff)-Seismicity plot along reflection profiles 1,2, and 3 with interpretive geological section.

Figure 27(p. 38f)-Final interpretive geological section across Chehalis Basin and SWCC region. Figure 28(p. 39f).Paleotectonic reconstruction for SWCC region.

Figure 29(p. 41f). Details of Morton antiform geology with location of stratigraphic sample sections.

Figure 30(p. 42f)-Morton antiform paleocurrent data.

Figure 31(p. 44f)-Stratigraphic correlation section with variable Northcraft level.

Figure 32(p. 45f)-Stratigraphic correlation section with fixed Northcraft level.

- denotes pere followion toxe exere 


\section{PREFACE}

This report describes results of a synthesis of geological, geophysical and geochemical data from a largely volcanic rock covered region in southwestern Washington that has been identified as a underlain by thick marine sedimentary rocks. The work was funded by the Deep Source Gas projects at the Morgantown Energy Technology Center. The subproject which resulted in this report is centered in the Branch of Geophysics, U.S. Geological Survey in Denver. A lengthy period of cooperation between METC and the USGS has involved one task focused on the application of geophysical methods to the study of phenomena associated with fossil and active subduction zones and non-subduction suture zones that may have deeply emplaced sedimentary rocks. This report represents a summary synthesis of several geophysical and geological data sets.

\section{EXECUTIVE SUMMARY}

Limited possibilities exist for new hydrocarbon exploration regimes in the Pacific Northwest. Our goal in this presentation is to outline recent knowledge concerning a possible new exploration environment in the State of Washington. This frontier area occurs in southwestern Washington where extensive geophysical studies have been used to outline a proposed sedimentary basin hidden beneath volcanic rocks in the southern Cascades region (Stanley et. al, 1992). Electrical geophysical imaging using the magnetotelluric (MT) method first detected thick, electrically-conductive sequences believed to be associated with Eocene to Oligocene marine sedimentary rocks. The conductive section occurs at depths from about $1 \mathrm{~km}$ to $10 \mathrm{~km}$ in the southern Cascades region with thicknesses up to $10 \mathrm{~km}$. Careful consideration of physical properties and the correspondence of the morphology of the units to known fold sets suggests that the high conductivities are related to lithologic/stratigraphic units rather than to variations in physical properties. Our preference for the lithology of the anomalous section, based upon a study of regional geology and structure, is one dominated by marine shales of Eocene and older in age. Other possible lithologies that have been evaluated for the conductive section include non-marine sedimentary units of Tertiary age, highly altered volcanic flows, and pre-Tertiary metasedimentary rocks with large percentages of graphite. We refer to this anomalously conductive region as the southern Washington Cascades conductor (SWCC, Fig. 1).

Based upon evidence from the MT surveys, a large scale seismic reflection program was implemented by the Department of Energy. The surveys utilized a 1000 channel sign-bit recording system with five Vibroseis source units as energy. Downsweeps of the vibrators was employed with recording out to 15 seconds, although there was generally very little useable information in the seismic data below 
Figure 1-Location index for western Washington with seismic profile locations.

about four seconds two-way travel time. The data have been released on CD-ROM (Zilman, 1992) as USGS Open File Report 92-714. In addition, a high-resolution aeromagnetic survey of the suspected marine basin region has been completed and is available as USGS Open File Report No. 92-251 (Abrams, 1992). Although no new gravity data have been acquired, modeling of existing data has proved useful in examining certain aspects of the geology in the region.

The region in question has been examined using several types of data in addition to MT, seismic, magnetic, and gravity. Specific geological mapping tasks have been completed through funding by the Department of Energy and the USGS in the western part of the proposed basin near Morton, WA. Other regional geological studies using wells and outcrops done as part of the USGS Evolution of Sedimentary Basins programs have added information that constrain the possible nature of the SWCC rocks and their tectonic setting. Recently, evaluation of patterns of seismicity in the SWCC region has demonstrated the likelihood of several parallel and step-over strike-slip faults that may have produced the proposed basin or altered its geometry. In addition, the seismicity patterns trace the axis of key anticlinal structures and thrusts.

The nature of the SWCC is still largely a mystery in spite of our inferences regarding the rock types, as well as other factors that are important in evaluating the region for hydrocarbon potential. Tracing the conductive rocks to the surface in the area near Morton, WA and close to the surface just west of Mount Rainier suggests a correlation of the anomalous units with rocks like those of the Raging River, Carbonado, and McIntosh Formations, all of middle Eocene age.

The Morton antiform near Morton, WA, a main structure within the SWCC region, is cored with Eocene Puget Group sedimentary rocks of both marine and nonmarine origin interpreted from surface measurements, seismic reflection and MT data. These units were largely deposited in a series of interconnected basins east of the terrane boundary between the Coast Range province (underlain by Eocene marine basaltic basement) and the Cascades/Pre-Tertiary province (underlain by a diverse basement of pre-Tertiary rocks). Puget Group strata exposed in the core of the antiform are deltaic in origin and consist of alternating intervals of nonmarine and shallow marine rocks. Elsewhere in the region, the Puget Group rocks are underlain by fine-grained marine strata of the Raging River Formation (Johnson, 1992); similar and older marine rocks probably underlie the Morton area. Samples of the Raging River Formation contain significant amounts of organic matter, but are overmature and do not yield reliable petroleum source-rock data. Occurrence of numerous coals indicates some possibility for methane sourced from the coals.

Vitrinite reflectance data from an AMOCO stratigraphic test well in the Morton 


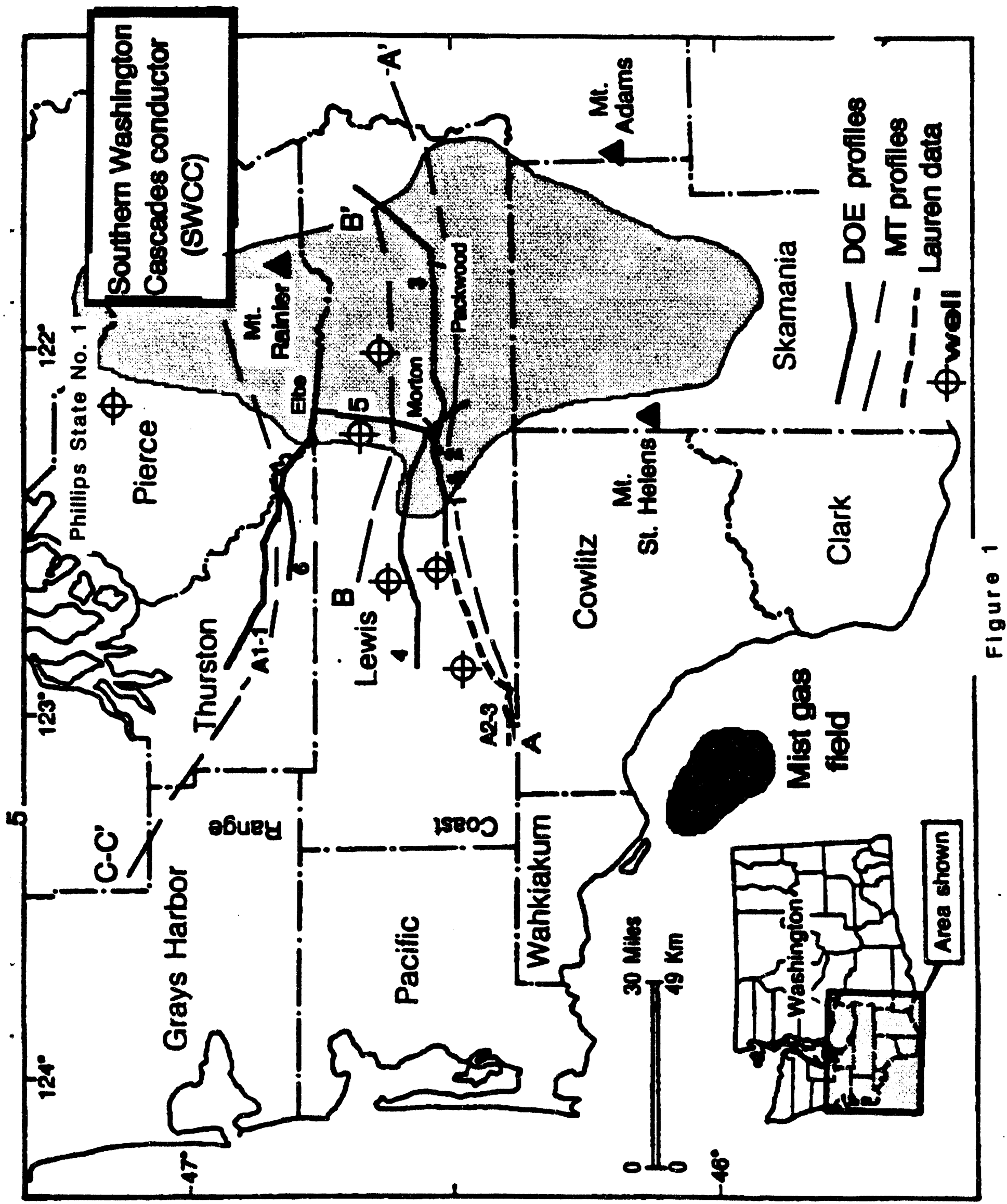


antiform range from $R_{0}=1.34$ to 0.96 percent (depths of $524 \mathrm{~m}$ and $171 \mathrm{~m}$, respectively). Samples from two surface sections on the west flank of the antiform have $R_{0}$ values of 0.59 to 0.78 percent. Samples from a section in Coal Canyon on the east flank of the antiform have values ranging from 0.40 to 0.52 percent. Samples collected adjacent to small intrusions have elevated vitrinite reflectance values ranging up to 2.21 percent. Coal-rank data (Walsh and Phillips, 1982) show predictable increases in maturation eastward across the region as the Cascades magmatic arc is approached.

Preliminary petrographic analysis indicates that sandstones from the Morton antiform are largely plagioclase-rich, arkosic arenites, with variable porosity controlled by calcite cement and clay minerals. Unsubstantiated reports of secondary porosity in Puget Group units mapped in mines in the Morton area may be an indication of possible reservoir potential. However, extensive evidence for transpressive deformation, fracturing, and faulting of the Morton antiform must be considered negative factors for the occurrence of a suitable reservoir. Such considerations, along with the limited evidence for adequate source rocks, make the Morton antiform area a high risk exploration target, but possibly one of the few remaining to be tested in western Washington.

\section{INTRODUCTION}

The Deep Source Gas project is part of the Unconventional Gas Resources program in the Department of Energy. In 1982, deep gas research evolved as a natural outgrowth of research on geologically complex natural gas reservoirs (Gwilliam, 1990). Such natural gas resources require long-term, high-risk research and development. The level of risk is such that little or no private sector research is being done. Deeply sourced gas is defined as methane that is generated at depths greater than $10 \mathrm{~km}$ (30,480 feet). The Deep Source Gas project was the result of a workshop held in Morgantown, West Virginia in 1982, where it was recognized that the role of methane in the nation's energy budget was increasingly significant. This workshop reviewed deep methane sources from the perspective of three mechanisms for its development:

- Abiogenic gas-Gas of nonbiologic origin, emplaced primordially in the Earth's mantle.

- Subducted, organic carbon gas-Gas from hydrocarbon-generating marine sediments, deeply emplaced in the Earth's crust and mantle through plate tectonic movements in the Earth's crust.

- Deep Sedimentary Basin gas-Gas generated from known and unknown, deeply emplaced sedimentary rocks within basins.

Supportable estimates of a large component of carbon entering the mantle at subduction zones (Hilde, 1983) led to a more intense examination of key active and fossil subduction zones, especially to evaluate the processes active in such region as they impact methane generation. It was believed that there might be areas where 
large sections of partially subducted or otherwise tectonically emplaced sedimentary rocks might occur at depths where active methane sourcing would occur. This deeply sourced methane might be trapped in overlying, possibly younger, structures. The complex environments which would be indicated for such regions make the application of normal seismic reflection methods difficult and expensive. Another geophysical technique, magnetotelluric (MT) sounding, was employed as a reconnaissance tool to investigate the occurrence of deeply emplaced sedimentary complexes, combined with gravity and magnetic methods, and followed by deep seismic reflection surveys in two instances.

The western borderland of the U.S., particularly in Washington, Oregon, northern California, and Alaska, was selected as the region to attempt to locate previously unidentified deep sedimentary systems that might serve as methane sources. Reconnaissance MT surveys and gravity/magnetic studies were carried out across the Klamath Mountains suture zone in northern California and southwestern Oregon, the Mist gas field area in northwestern Oregon, across Eocene suture zones in western Washington, and Cretaceous suture zones in the Methow Trough in northwestern Washington and the Alaska Range of Alaska (Stanley and others, 1990). Results from the Klamath Mountains region indicated a very low probability for deeply emplaced sedimentary rocks in the suture zone, and although the Methow Trough survey indicated deep, carbonaceous sedimentary rocks the thermal maturity data suggested that this region was not promising from a gas generation standpoint. The study in the Alaska Range found dramatic evidence foi large-scale underthrusting of carbonaceous sedimentary rocks, but little is known about the thermal maturity (metamorphic state) of the hypothesized sedimentary rocks. In addition, because of the lack of commercial interest in irontier exploration for methane in Alaska, this study area was not deemed immediately appropriate for further research. The western Washington study, however, proved to be very interesting, with a possible thick marine sedimentary sequence found in the southern Washington Cascades. Many lines of evidence point to this sequence as being a possible good source for methane, as

Figure 2 (following page-Generalized geologic Index map of western Washington, with swCC, Mist gas field, and location of MT and DOE seismic profiles.

detailed in the body of the report. The western Washington study area was also attractive because of nearby Mist gas field (Figure 2), northwest of Portland, Oregon, the lack of industry exploration in the area, and the existence of an established gas pipeline network nearby. Thus much of the effort in deep source gas exploration in the western U.S. using geophysical methods was focused upon this area and no further research was carried out in the other regions. 


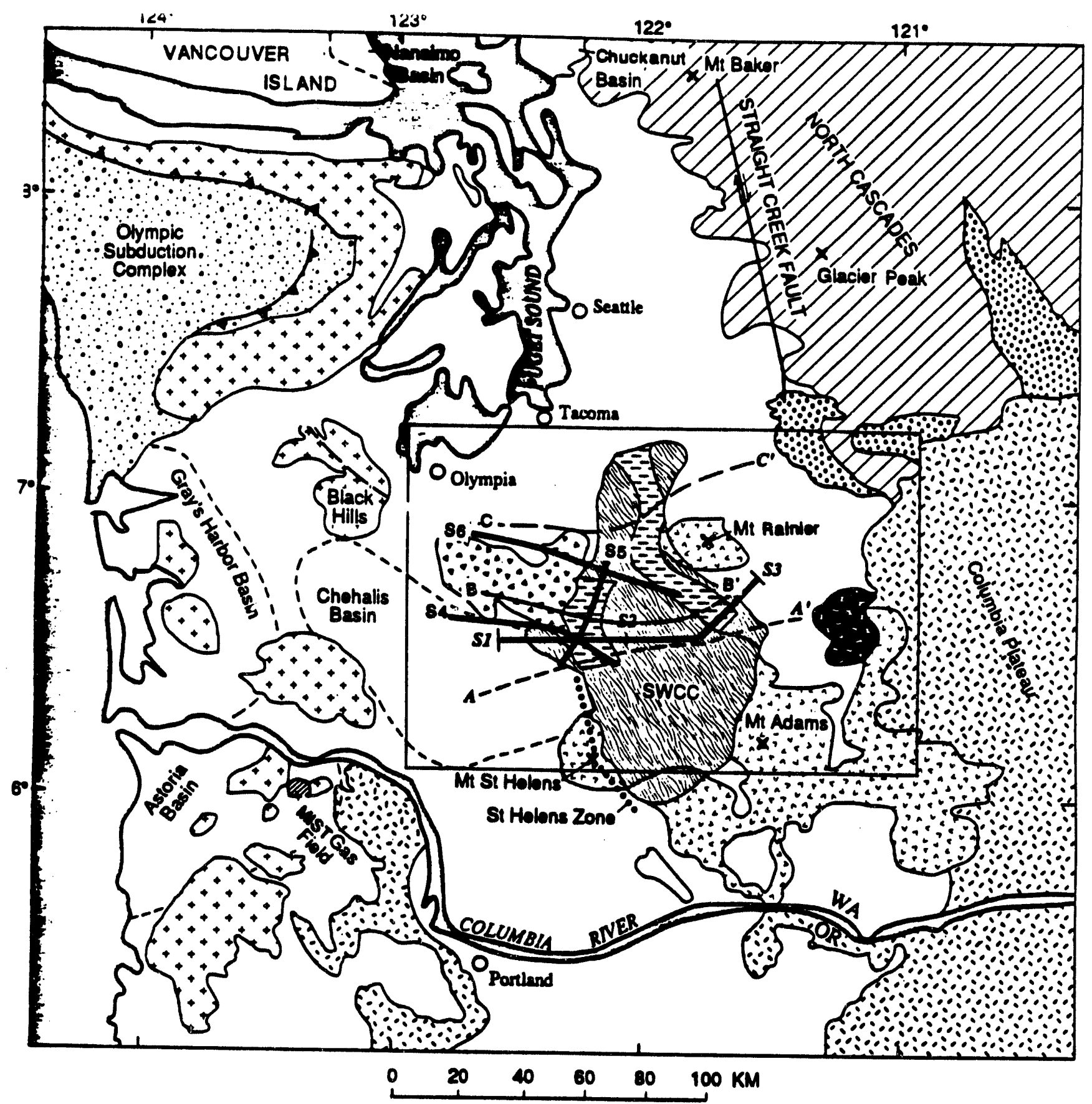

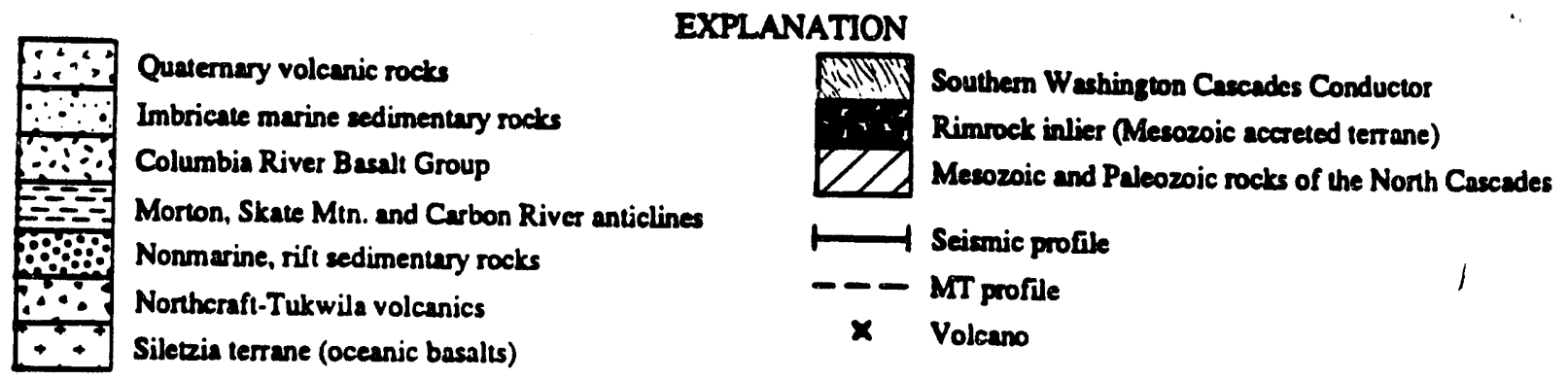

Figure 2 


\section{Overview of Hydrocarbon Exploration History in the Region}

The Pacific Northwest states of Oregon and Washington encompass a region of complex geological settings in which petroleum exploration has been largely unsuccessful because of a variety of geological factors and the low quality of typical seismic data. The system of late Tertiary sedimentary basins west of the Cascades (Fig. 2) has been interpreted as containing largely immature source rocks, but with some good reservoir rocks (Armentrout and Suek, 1985). These basins formed on basement consisting of oceanic basalts of the Coast Range province, and are filled with $3.5 \mathrm{~km}$ of marine sandstones, shales, and minor volcanic rocks. The only producing field with ongoing development in the Pacific Northwest is the Mist gas field, wes, of Portland, Oregon (Fig. 2).

Eocene to Miocene sedimentary units in the Olympic Peninsula appear to contain good source rocks (Snavely, 1987) and some oil has been produced from the coastal zone of the Peninsula and in the Grays Harbor basin to the south (Braislin and others, 1971). Methane is venting from a fault zone on the north side of the Olympic Peninsula (Kvenvolden and others, 1987). Organic geochemical analyses by Kvenvolden arid others (1987) suggest that the deep parts of the Olympic melange assemblage are mature for oil and gas, and Snavely (1987) suggests that the highest potential for oil and gas generation in the western Washington region occurs in the thick, accretionary melange-wedges of the Olympic Peninsula.

Drilling in the Puget Lowland of Washington (Fig. 2) has not resulted in production, but many wells have produced shows of oil and/or gas. Gas seeps in the Black Diamond, WA area (Mullineaux, 1970) and elsewhere in the Puget Lowland are believed to derive from coal bed methane at shallow depths. Testing of the Phillips State No. 1 well drilled east of Tacoma extracted a measurable quantity of highparaftin oil at depths of 7060-7120 feet (Brown and Ruth Laboratories, 1982).

Extensive hydrocarbon exploration has been carried out in the Columbia River Plateau (Fig. 2), based upon initial, non-commercial, gas discoveries by Shell Oil Co. (Northwest Oil Report, 1983). This gas appears to have come from Tertiary nonmarine sediments in which flow is restricted by porosity-plugging authigenic minerals derived from volcanic clasts. Much speculation has developed concerning the possibility that the Plateau is underlain by Mesozoic sedimentary rocks similar to those that crop out in the Blue Mountains, Oregon (Kleinhaus and others, 1984; Miller, 19891 . 


\section{GEOLOGICAL/TECTONIC SETTING}

The SWCC occurs partially within the Cascade Range that extends from northern California to British Columbia; volcanos of the Cascades (Fig. 2) represent the magmatic arc associated with post $36 \mathrm{Ma}$ subduction of the Juan de Fuca plate and its predecessors. The Cascades magmatic arc may have begun to develop about 44 Ma with andesitic dikes that intruded the Crescent Formation (Snavely, 1987) and certainly was well established by $36 \mathrm{Ma}$ at the time of eruption of the thick Ohanapecosh Formation volcanic flows near Mt. Rainier (Fig. 2). Pre-Tertiary crust in the region is composed of Mesozoic and older accreted terranes, volcanic arcs, and underplated magmatic rocks. This older accreted crust is exposed in the North Cascades (Fig. 2) of Washington and in the Blue Mountains and Klamath. Mountains of Oregon.

A key feature of the geology of the Pacific Northwest margin is a terrane of oceanic basalts (Fig. 2), called "Siletzia" by Irving (1979), that forms the basement in western Oregon and Washington. The oceanic basalt assemblage is represented by the Siletz River Volcanics in Oregon (Snavely, MacLeod, and Wagner, 1968), Crescent Formation in Washington (Cady, 1975), and Metchosin volcanics on southern Vancouver Island (Muller, 1977) and is estimated by Duncan (1982) to have a volume of $250,000 \mathrm{~km}^{3}$. Gravity and magnetic data have been analyzed by Finn (1989) who, along with Stanley and others (1987 and 1989), interpret that the Siletzia units extend underneath the region between the Black Hills and Mount Rainier (Fig. 2).

Crescent Formation basalts and similar rocks in Oregon that form the basement rocks west of the Cascades are now widely believed to have formed in a continentalmargin rift setting (Wells and others, 1984; Snavely, 1987; Babcock and others, 1992). Consistent with this interpretation, Johnson $(1984,1985)$ and Johnson and others (1994) suggested that the eastern margin of this rifted terrane was a dextral strike-slip fault, the Puget fault. Northward motion of the Coast Range block along the Puget fault. was accommodated to the north by south-directed thrusting on southern Vancouver Island (Clowes and others, 1987) and by folding and faulting within the Coast Range block in the Straits of Juan de Fuca and on the northern Olympic Peninsula (Snavely, 1987). Johnson $(1984,1985)$ suggested that most strike-slip motion on the crustal boundary occurred prior to the late Eocene, after which strike-slip motion diminished and was distributed on several fault zones in the southeastern Puget Lowland (Johnson and others, 1994).

Synchronous with Eocene rifting in the Coast Range province, the eastern preTertiary basement province experienced significant transtensional deformation, characterized by dextral strike-slip faulting, formation of rapidly subsiding sedimentary basins, and uplift and(or) intrusion of crystalline rocks (Johnson, 1985). Eocene sedimentary rocks form units as thick as $6,000 \mathrm{~m}$ or more occur in these pull-apart structures and comprise some of thickest nonmarine sequences in North America (Johnson, 1985). Pull-apart basins are rifts or graben structures caused by the effects of differential movement on strike-slip faults. Other terms roughly synonymous with 
pull-apart structures are "rhombochasm" (Carey, 1958) and wrench grabens (Belt, 1968); terminology and a review of tectonic aspects of this type of structure is given in Mann and others (1983). Subsidence in the Coast Range province following extrusion of the Crescent Formation was much slower and probably of thermal origin (Johnson and Yount, 1992).

Due to their different histories, there are significant contrasts in Eocene basin geology across the Cascades-Coast Range crustal boundary. In the Seattle area,

Figure 3-Detailed geologic map of central swCC region and DOE seismic reflection profiles. The location of WT profile EE $P$ is also indicated. Geologic base was digitally scanned from walsh and others (1987) and shotpoint maps for the reflection lines plotted from data on CD-ROM produced by Zilman (1993). The decade numbers on the seismic lines represent each tenth shotpoint. Actual shotpoint numbers are contained in Appendix c. Legend for selected units from Walsh and others (1987) is shown in the lnwer part of the figure.

Johnson and others (1994) describe major differences in thickness and facies of early and middle Eocene strata from west to east across the crustal boundary. In the southwest Washington area of the DOE seismic survey, there is also a major increase in thickness of Eocene strata from west to east across this zone. In the Chehalis basin (see discussion below) west of the zone, the thickness of the Eocene section from the Crescent basaltic basement to the base of the Northcraft Formation is about $2 \mathrm{~km}$. In the Morton antiform east of the zone, there is as much as 4-8 km of Eocene strata below the base of the Northcraft Formation. This thickness contrast and other aspects of the regional geology of southwest Washington area are described later in this report in sections on the Chehalis basin and the Morton antiform.

Figure 4- Schematic geologic map of the Chehalis Basin and bounding uplifts. $A-A^{\prime}, B-B^{\prime}$, and $C-C^{\prime}$ show lines of cross section shown in Figures 6, 7, and 8. Abbreviations as follows: $\mathrm{A} 5$ - AMOCO wC-83-5 borehole; $B C=$ Bear Canyon; $B M=$ Bergen Mountain stratigraphic section; $C e=$ Centralia; $C h=$ Chehalis; $K=$ Earl F. Siler and J.W. Tanner Kostick No. 1 borehole; $M$ = Norton; MA - Morton antiform; MS = Mineral stratigraphic section; $\mathrm{NL}=$ Newaukum Lake eruptive center for Northcraft Formation of Hagen

In the area of the DOE seismic survey (Fig. 3), Stanley and others (1987, 1992) used diverse geophysical data sets to suggest this boundary occurs in the vicinity of Bear Canyon on the east flank of the Chehalis Basin (Fig. 4), and coincides 
$122^{\circ} 30$

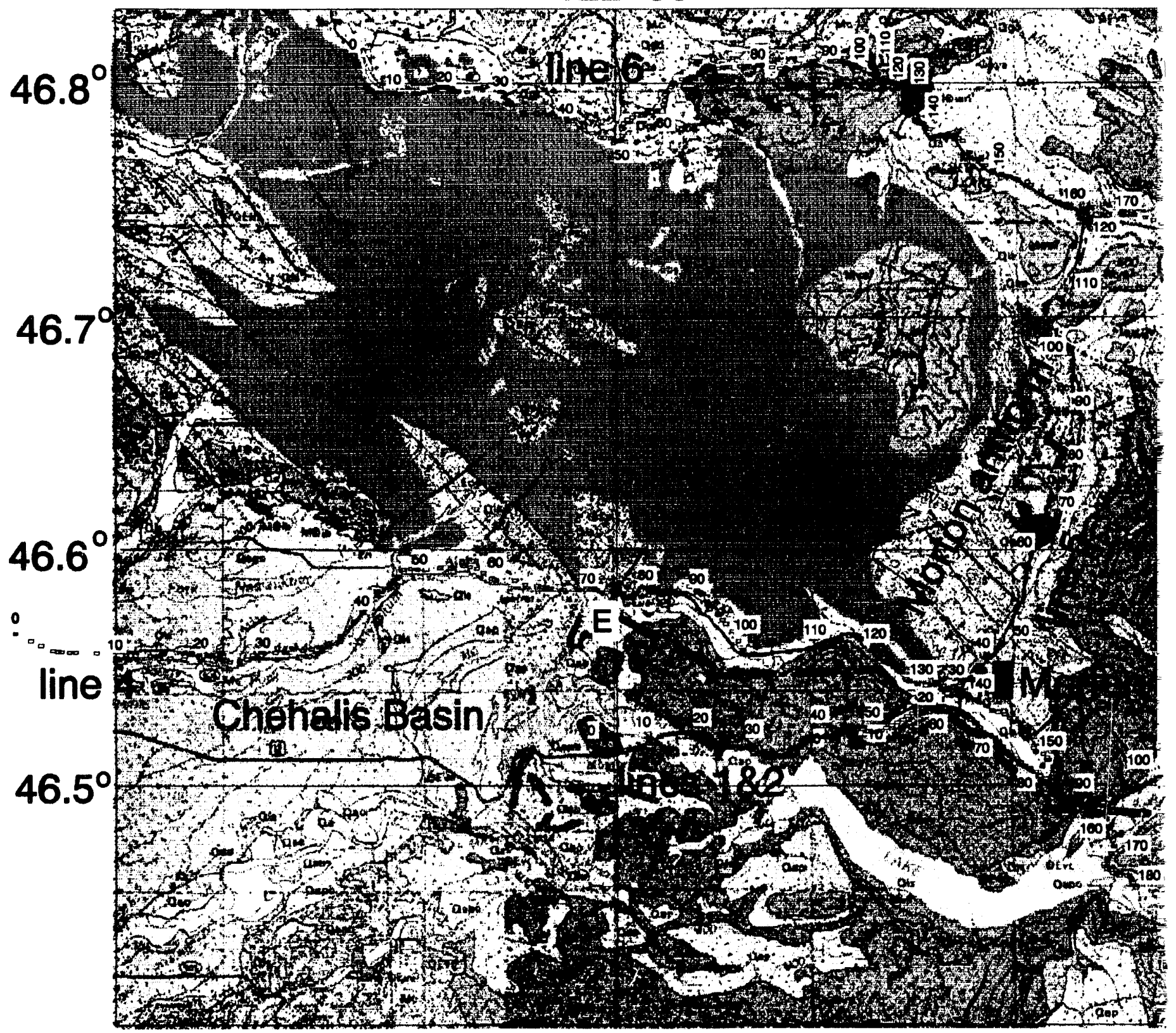

$122^{\circ} 30$

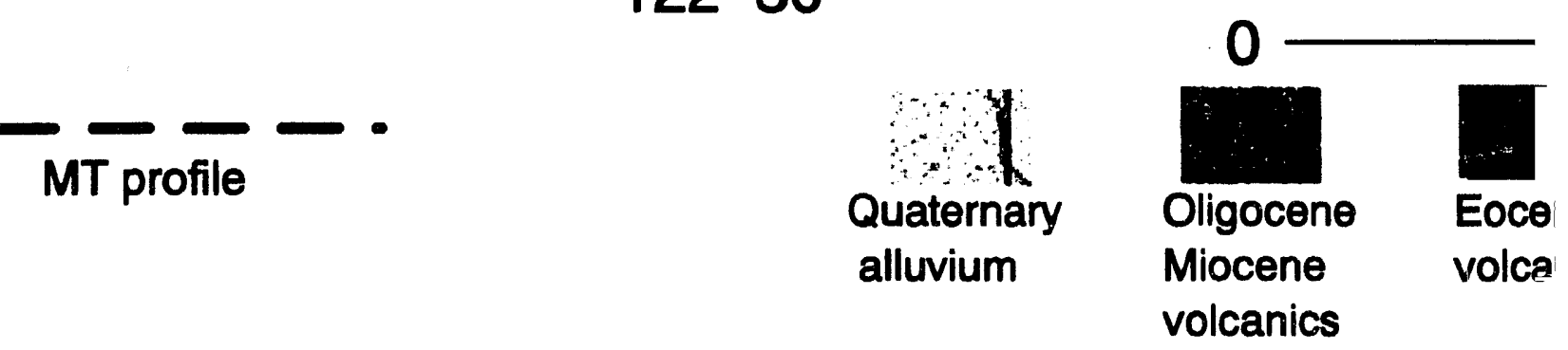




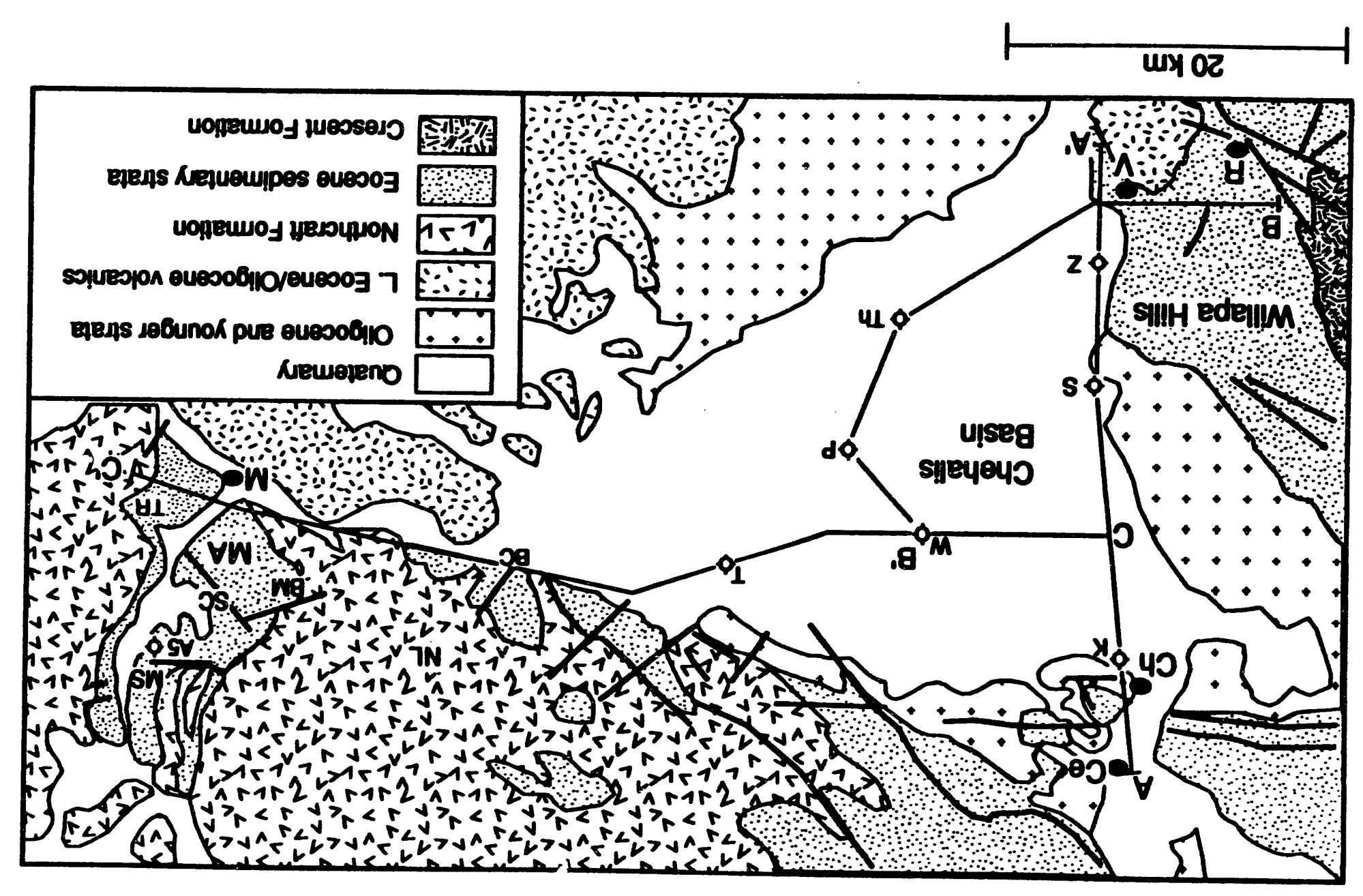


approximately with the Saint Helens zone (SHZ) of Weaver and Smith (1983). The DOE network of seismic reflection lines in southwest Washington transects this major north-trending crustal boundary between basement rocks of the pre-Tertiary Cascade province to the east and the Eocene Coast Range province to the west, with the proposed sedimentary complex of the SWCC caught between. This contact is covered by late Eocene and younger rocks and can be located and characterized only on the basis of geophysical data.

Western Washington lies at the southern end of a belt of dextral slip related to oblique convergence of the Juan de Fuca plate and its predecessors, such as the Kula and Farallon plates. From several hundred to several thousands of km of strike slip have been postulated for the borderland terranes of British Columbia, the Yukon Territories, and Alaska in post-Cretaceous time (Irving, 1983; Irving and others, 1980; Jones and others, 1977). Misch (1977) and Davis and others (1978) postulated that the Straight Creek fault (Fig. 2) might have about $190 \mathrm{~km}$ of right-lateral displacement. Price and others (1985) suggest that the Fraser Fault (northern extension of Straight Creek fault) had about $70 \mathrm{~km}$ of offset since the mid-Cretaceous. Motion of the fault system must have ceased by time of intrusion of the Chilliwack batholith in Oligocene time (Price and others, 1981). Detailed study of the southern end of the Straight Creek fault by Tabor and others (1984), found a Tertiary history of dominantly vertical movement. However, they interpret that horst-and-graben structures and en-echelon fold axes in the Eocene Swauk Formation suggest early Eocene right-lateral shear along the Straight Creek fault.

Paleomagnetic data document significant block rotations of the Coast Range (Simpson and Cox, 1977; Globerman and Beck, 1979; Magill and others, 1981; Wells, 1989). There is agreement among these various authors that the Coast Range has undergone a relative clockwise rotation with respect to the North America craton of about $25^{\circ}$ in the north and up to $75^{\circ}$ in the south. There have been several models proposed by Simpson and Cox (1977) and Wells (1989) to explain this rotation. The most current analysis by Wells (1989) includes paleomagnetic data from the Black Hills (outcrops of Siletzia) near Olympia, Washington (Fig. 2); this information indicates that much of the overall rotation of the Coast Ranges was taken up in individual block rotations, probably associated with dextral shear.

In the middle Eocene, feldspathic-quartzose deltaic sediments (Armentrout and Suek, 1985) prograded across Oregon and Washington, filling the gaps between the seamounts. Isolated, but active volcanic centers developed within the prograding delta system, leading to eruption of the basalt to andesitic Tukwila and Northcraft Formations (Fig. 2). Marine shales and siltstones of units such as the Mclntosh and Raging River Formations (Snavely and others, 1958) formed the basement for this deltaic system. The Cascades magmatic arc was the source of voluminous felsic lavas and ash flows of Oligocene age like the Ohanapecosh Formation that filled a continental depression in the area of the present Cascades and eastern Puget Lowland (Fig. 2). The Miocene Columbia. River Basalt Group (Fig. 2) erupted from 17 to 6 m.y.b.p. (McKee, Swanson, and Wright, 1977), flooding the continental-sedimentfilled, backarc basin east 
Pre-Tertiary basement rocks of the Cascades include diverse metamorphic, igneous, and sedimentary rocks that comprise several distinct crustal terranes with allochthonous and(or) exotic origins. Final stages of accretion/assembly of these crustal terranes occurred by the Late Cretaceous, after which these rocks formed the "stable tiamework" of the Washington continental margin. The southernmost exposures cf pre-Tertiary rocks in the Washington Cascades occur in the Rimrock Lake inlier (Miller, 1987; Miller and others, 1993), south-southeast of Mount Rainier and about $15 \mathrm{~km}$ east of the east end of DOE seismic line 3 (Fig. 3).

\section{Deep Well Information}

Several deep wells near the SWCC provide the best information about deeper parts of the Eocene stratigraphic section. The deepest well in the SWCC region is the Phillips State No. 1 (TD 12,920') that was completed east of Tacoma (Fig. 1). The well penetrated alternating sequences of sandstones, siltstones, shale, and coals of the Puget Group, interpreted in a report by Brown and Ruth Laboratories (1982) to be marginal marine facies. The upper 7120 feet of the section contains about $50 \%$ sandstone/siltstone and $50 \%$ shale. From 7120 to 7660 feet, greenish-gray, volcanic rocks of the Tukwila Formation weres encountered. Below 7660 feet shales dominate, traces of coal start to appear, and zeolites fill most of the fractures. Greenish-gray volcanic rocks were also noted at 9320-9540 feet. Below 12,560 feet to TD, the well section consists of $100 \%$ shale. The induction electrical $\log$ for the Phillips well indicates resistivities for the upper 7200 feet of $40-60 \mathrm{ohm}-\mathrm{m}$. Resistivities decrease rather steadily below this point to $15-20 \mathrm{ohm}-\mathrm{m}$ at the bottom of the well. This pattern is to be expected from the changes in the ratio of sandstones to shale; zeolites below 7660 feet also contribute to lowered resistivities.

An organic geochemical study of core and cuttings from the Phillips well (Brown and Ruth Laboratories, 1982) showed that the upper 7800 feet of the well had vitrinite reflectances of approximately $0.4 \%$ to $0.6 \%$, whereas the section below this depth had reflectances more typically near $1 \%$. The vitrinite reflectance values of the section below 7800 feet reflect maturity of the organic material compatible with oil generation (Tissot and Welte, 1980). This increase in thermal maturity of the organic material may be due to a thermal pulse connected with the Tukwila volcanic center. Measurable quantities of a high-paraffinic oil were extracted from the interval 7060 7120 and probably migrated in from below the measured section, because the zone in which they were found is thermally immature. The high vitrinite-reflectance values below 7200 feet in the well may increase with depth so that underlying pre-and lower Eocene marine units may be increasingly mature, but this scenario is dependent upon whether the maturation recorded in the Phillips well is indeed due to volcanism from the Tukwila magmatic center (Eocene) and later Cascades plutonism and not just to deep burial. Walsh and Phillips (1983) present evidence from coal rank data for increased thermal maturation associated with the Oligocene to Holocene Cascades magmatic arc. The Phillips State No. 1 well is within $30 \mathrm{~km}$ of Mount Rainier, the largest volcanic center in the Cascades, and the combined thermal effect of this 
volcano, earlier Cascades vents, and the Tukwila volcanic center was just enough to put the rocks at depths greater than $7200^{\circ}$ in the oil window. This observation suggests that the thermal maturation problem must be evaluated carefully.

Oil and gas shows have been documented in other drill holes in the area northwest of Mount Rainier. Mullineaux (1970) describes a large number of oil and gas shows from drilling on the Black Diamond anticline, a small structure sub-parallel to the Carbon River anticline (Figs. 2,3). Mullineaux states that wells in the area of the Black Diamond anticline produced oil and gas shows from all parts of the Puget Group. Although the documented evidence for Mullineaux's statements are not available, a gas well drilled at Flaming Geyser on the Black Diamond anticline produced salt water and continues to produce open flow of minor amounts of methane, although this gas has been thought to be produced largely from coal beds (pers. comm., T. J. Walsh, Washington Dept. of Natural Resources). In addition to hydrocarbon shows from wells in the region, a small oil seep has been noted in the Bear Canyon (Fig. 4) area (Hedges, 1949).

Snavely and others (1958) report on a drillhole of $6000^{\circ}$ depth in the Tenino area that penetrated the complete section of Puget Group rocks and an extensive section of the Mclntosh Formation. No information is available on hydrocarbon shows in the well, but it is safe to assume that there were no producible horizons. This well is important because of the stratigraphic information recorded on the Mclntosh Formation, to be discussed in a subsequent section. A 10,820' TD well completed in the Chehalis Basin, the Shell Thompson No. 1 (Fig. 4) penetrated 7300 feet of coalbearing, marginal marine clastic rocks of the Eocene Skookumchuck Formation (Fig. 5 ) and $3500^{\prime}$ of Northcraft volcanic rocks.

A $8200^{\circ}$ depth drillhole was completed in September, 1989 by Meridian Oil Company approximately $10 \mathrm{~km}$ NE of Morton, WA. Information from this hole is still proprietary, but it is likely that the drill was still in volcanic rocks, because the interpretation of MT profile BB' (Fig. 2) indicates resistivities of about $150 \mathrm{ohm}$-m to depths of 3-4 km in the vicinity of the drillhole. In addition, the geologic map of Walsh and others (Fig. 3) indicates that the well was drilled in a syncline where it would encounter thick Stevens Ridge or Ohanapecosh Formation volcanic rocks.

The focus of hydrocarbon exploration in western Washington has been largely upon Eocene to Oligocene marine sedimentary systems. The rocks in these basins are mostly too thermally immature to be hydrocarbon sources (Armentrout and Suek, 1985). The search for other sedimentary systems with mature source rocks has brought us to investigate the possibility that proposed sedimentary rocks in the southern Washington Cascades conductor (SWCC) constitute such viable source rocks. In order to evaluate the SWCC as a possible location for hydrocarbon source rocks, it is necessary to evaluate the available constraints upon lithology, thermal history and paleotectonics of the SWCC. We will attempt these tasks in the following sections, and discuss the details of recent seismic reflection data as they relate the SWCC anomaly. However, to understand essential stratigraphic controls that are needed to interpret the geophysical data, we will begin with a detailed discussion of the nearby Chehalis Basin. 


\section{CHEHALIS BASIN}

The Chehalis basin is a $\sim 500-600 \mathrm{~km}^{2}$, three-sided depression of Quaternary sediments bounded to the north, west, and southeast by bedrock uplifts (Fig. 4). We discuss this basin in detail because it provides key stratigraphic information needed to understand the SWCC and details of the main hydrocarbon play identified in the

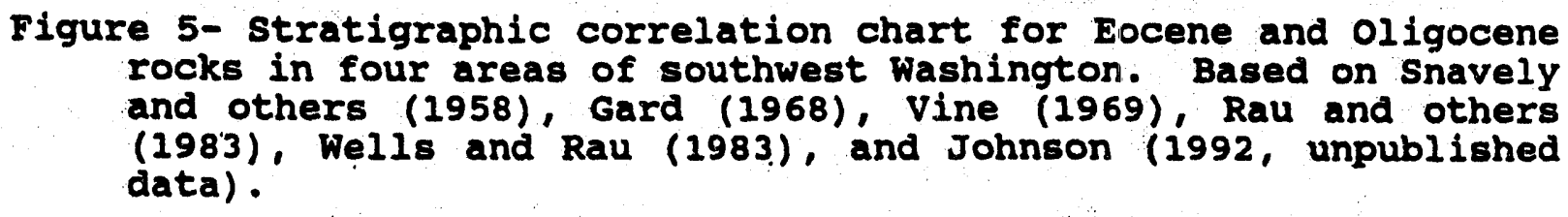

Figure 5- Stratigraphic correlation chart for Eocene and Oligocene rocks in four areas of southwest Washington. Based on snavely and others (1958), Gard (1968), Vine (1969), Rau and others (1983). Wells and Rau (1983), and Johnson (1992, unpublished data).

Morton antiform (to be discussed in later stages of the report). The Chehalis basin is bounded to the north and separated from the Puget Lowland by an uplift of Paleogene rocks that extends eastward from the Centralia-Chehalis area to Bear Canyon. The

Figure 6- Schematic north-south cross section $A-A^{\prime}$ across the western Chehalis basin. Iine of sectios is shown in Figure 4.

Willapa Hills, on the west flank of the Chehalis basin, are underlain by Paleogene and minor Neogene rocks. The southeast flank of the basin, underlain by Paleogene volcanic rocks and Neogene sedimentary strata, extends from Vader to the Bear Canyon area. Two large rivers, the Cowlitz and the Newaukum, flow west out of the Cascades and across the Chehalis basin. Geologic relationships in the Chehalis basin and on its northern, western, and eastern flanks are shown in the schematic cross sections of Figures 6, 7, and 8. These schematic cross sections are based largely on data from outcrop and borehole studies, seismic reflection profiles, and magnetotelluric surveys. We use the stratigraphic chart of Figure 5 as a guide to the interpretation. Schematic Cross Section AA'

Schematic cross section A-A' (Fig. 6) extends south from Chehalis to Olequa, across the west flank of the Chehalis basin. The cross section roughly parallels Lauren seismic reflection profile A2-1. Geologic control is provided by outcrops near Centralia and Chehalis and in the eastern Willapa Hills, and by analysis of samples and logs from the Shell Sturdevant No. 1, Shell Zion No. 1, and Earl F. Siler and J.W. Tanner Kostick No. 1 boreholes (W.W. Rau, written commun. to Johnson, 1992, and S.Y. Johnson, this study). 


\begin{tabular}{|c|c|c|c|c|c|c|}
\hline $30 \neg$ & & & $\begin{array}{l}\text { Willapa } \\
\text { Hills }\end{array}$ & $\begin{array}{l}\text { Centralia- } \\
\text { Chehalis } \\
\end{array}$ & $\begin{array}{l}\text { Morton- } \\
\text { Carbonado }\end{array}$ & $\begin{array}{c}\text { Tiger } \\
\text { Mountain }\end{array}$ \\
\hline $35-$ & 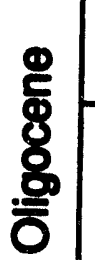 & 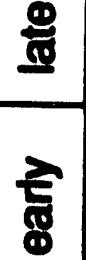 & $\begin{array}{l}\text { Lincoln } \\
\text { Creok } \\
\text { Formation }\end{array}$ & $\begin{array}{l}\text { Lincoln } \\
\text { Creok } \\
\text { Formation }\end{array}$ & $\begin{array}{l}\text { ecosh } \\
\text { ition }\end{array}$ & $\begin{array}{l}\text { unnamed } \\
\text { marine } \\
\text { strata }\end{array}$ \\
\hline & \multirow{4}{*}{ 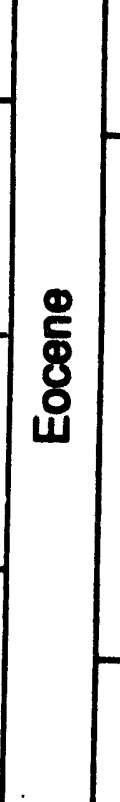 } & $\stackrel{\mathscr{0}}{\mathbb{1 0}}$ & $\begin{array}{l}\text { Cowlitz } \\
\text { Formation }\end{array}$ & $\begin{array}{l}\text { Skookum- } \\
\text { chuck } \\
\text { Formation }\end{array}$ & \multirow{2}{*}{ 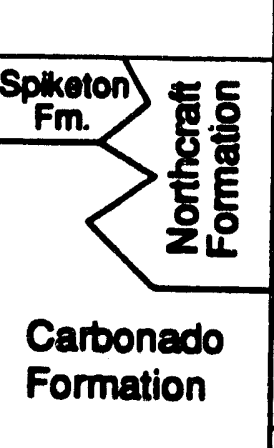 } & \multirow[b]{2}{*}{$\begin{array}{c}\text { Tiger } \\
\text { Mountain } \\
\text { Formation }\end{array}$} \\
\hline \multirow{3}{*}{$\begin{array}{c}45-1 \\
50-1\end{array}$} & & \multirow[t]{2}{*}{$\frac{0}{\frac{0}{3}}$} & $\begin{array}{l}\text { Molntosh } \\
\text { Formation }\end{array}$ & $\begin{array}{l}\text { Mclntosh } \\
\text { Formation }\end{array}$ & & \\
\hline & & & \multirow{2}{*}{$\begin{array}{l}\text { Crescent } \\
\text { Formation }\end{array}$} & \multirow{2}{*}{$\begin{array}{l}\text { Crescent } \\
\text { Formation }\end{array}$} & \multirow{2}{*}{$\begin{array}{l}\text { SWCC } \\
\text { marine } \\
\text { strata }\end{array}$} & $\begin{array}{l}\text { Raging } \\
\text { River } \\
\text { Formation }\end{array}$ \\
\hline & & 롱 & & & & $\begin{array}{l}\text { basement } \\
\text { not exposed }\end{array}$ \\
\hline
\end{tabular}

Figure 5 


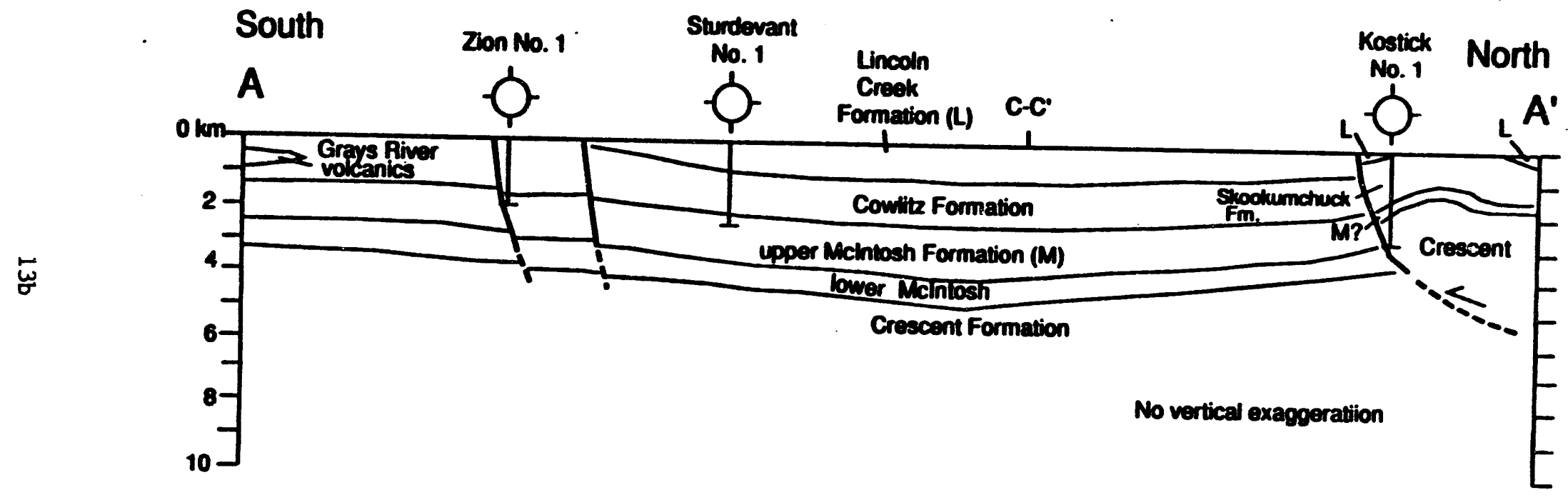

Figure 6 
At its south end, the section above the Crescent Formation basaltic basement consists of the early Middle Eocene Mclntosh Formation and the late Middle to Late Eocene Cowlitz Formation, which includes interbeds of the volcanic rocks of Grays River (Henriksen, 1956; Wells, 1981; Walsh and others, 1987). Using seismic reflection data, Ise (1985) designated part of what is here considered to be the lower Mcintosh Formation as "unknown marine sediments". Krehbeil (1993b) adapted Ise's interpretation of the seismic data in a similar cross-section. In making this designation, Ise and Krehbiel correctly pointed out this almost certain marine section pinches out in the subsurface of the Chehalis Basin, is nowhere locally exposed, and has not been penetrated by boreholes. We prefer to designate these strata as a lower part of the McIntosh Formation, keeping with established stratigraphic nomenclature for rocks overlying the Crescent Formation elsewhere in southwest Washington (e.g., Wells and Rau, 1983; Rau and Armentrout, 1983; Rau and others, 1983).

To the north in the west-central part of the Chehalis basin, the Cowlitz Formation is overlain by a section as thick as about $500 \mathrm{~m}$ consisting of mainly Oligocene marine rocks of the Lincoln Creek Formation and lesser Quaternary strata. Basinal strata dip very gently into the center of the basin where Oligocene and younger strata reach their greatest thickness. Use of stratigraphic nomenclature for late Middle to Late Eocene sedimentary rocks changes at the northern basin margin; Cowlitz Formation-equivalent rocks are assigned to the Skookumchuck Formation in the Centralia-Chehalis area (Fig. 5) following Snavely and others (1958) and Rau and others (1983).

The northern end of schematic cross section $A-A^{\prime}$ shows a thrust fault along the northern basin margin. This fault is a continuation of a structural zone that forms the south flank of the Doty Hills to the west and is here referred to as the Doty fault. Based on interpretation of seismic reflection data, the block north of the Doty fault is characterized by a decreased depth to Crescent Formation basement and a much thinner Eocene section than in the Chehalis basin. This relationship suggests that the block north of the Doty fault was part of an Eocene basement high. We infer that this high was part of a basaltic seamount centered in the Black Hills to the north, where the Crescent is overlain by the Oligocene Lincoln Creek Formation and Eocene sedimentary rocks are absent. Eocene sedimentary rocks may have originally thinned over this uplift in the same way that they thin and pinch out over the Willapa Hills volcanic high of Crescent Formation on the southwest margin of the basin (see schematic cross section B-B'; Boswell and others, 1988; ise, 1985). The amount of vertical displacement on the Doty fault (about $1700 \mathrm{~m}$ ) shown on the cross section thus probably reflects a combination of faulting and original basement topography. Faulting is Eocene and younger in age.

\section{Schematic cross section B-B'}

Schematic cross section B-B' (Fig. 7) extends east through the eastern Willapa Hills from the Ryderwood area to Vader; then northeast along the Cowlitz River into the southern part of the Chehalis basin; then north into the central part of the basin. The western three-quarters of the cross section roughly parallels the western part of 
Figure 7- Schematic southwest-northeast cross section B-B' through part of the Chehalis basin. Line of section is shown in Figure 4.

Lauren seismic reflection profile A2-3. Geologic control is provided by outcrops in the eastern Willapa Hills, and by analysis of samples and logs from the Shell Thompson No. 1, Humble Oil and Refining Company Roscoe B. Perry No. 1, and the SelburnWashington Oil Corporation Wulz No. 1 boreholes (W.W. Rau, Written commun. to Johnson, 1992, and S.Y. Johnson, this study). Boswell and others (1988) have described seismic facies on the western portion of the Lauren seismic line, which parallels this section. Krehbiel (1993b) used all of Lauren A2-3 line in a regional schematic cross section that extends from the Willapa Hills into the central Cascade Mountains.

As in line $A-A^{\prime}$, the stratigraphy above Crescent basement in the eastern Willapa Hills and southern Chehalis basin consists of the lower McIntosh Formation (unknown marine sediments of Kreihbiel, 1993), the upper Mclntosh Formation, the Cowlitz Formation, the Lincoln Creek Formation, and a thin layer of Miocene to Quaternary sediment. Both Mclntosh units onlap the Crescent basement in the Willapa Hills, indicating this area formed an Eocene basement high attributed to seamount topography at the top of the Crescent Formation. From the Willapa Hills, Crescent basement dips gently northeast into the central part of the Chehalis basin.

Use of stratigraphic nomenclature in this section changes from southwest to northeast across the line based on the appearance of the volcanic Northcraft Formation at the stratigraphic level of the upper Mclntosh Formation (Fig. 5). Following Snavely and others (1958) and Rau and others (1983), strata above the Northcraft at approximately the same stratigraphic level as the Cowlitz Formation are referred to as the Skookumchuck Formation. By stratigraphic convention (Snavely and others, 1958; Rau and others, 19831, strata below the Northcraft are assigned to the Mclntosh Formation. The cross section compiled by Krehbiel (1993b) along the same transect violates this convention by designating considerable strata below the Northcraft as part of the Skookumchuck Formation. The proportion of volcanic rocks of the Northcraft Formation increase to the north and northeast, reflecting proximity to Northcraft volcanic centers (Hagen, 1987). In addition, Krehbiel (1993b) interpreted Lower Oligocene volcanic rocks of the Goble Formation to occur above the Skookumchuck Formation in the central part of the Chehalis Basin. This occurrence is unlikely, since the vents for the Goble Formation are considerably further to the south, near the Columbia River.

Schematic cross section C.C:

Schematic cross section C-C' (Fig. 8 ) is a regional line that extends east across 
Southwest

B

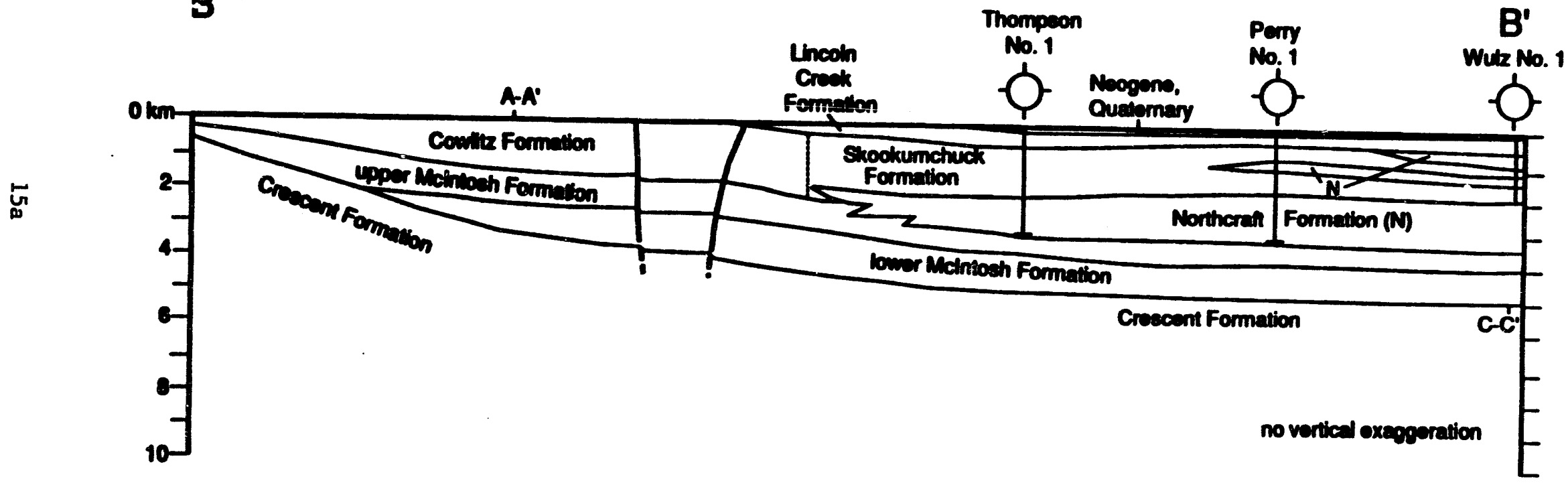

Figure 7 
the entire Chehalis basin to the Morton antiform. The cross section roughly parallels the eastern part of Lauren s6ismic reflection profile A2-4, and DOE line 4 (Figs. 2, 3)

Figure 8- Schematic west-east cross section $C-C^{\prime}$ across the Chehalis basin and into the Cascade foothills to Morton. Iine of section is shown in Figure 4.

Geologic control is provided by outcrops on the northern margin of the Chehalis basin, along the Tilton River, and in the Morton antiform, and by analysis of samples and logs from the Everett Trust and Savings Bank Trustee No. 1 and the Selburn-Washington Oil Corporation Wulz No. 1 boreholes (W.W. Rau, written comm. to Johnson, 1992, and S.Y. Johnson, this study). Ise (1985) constructed a cross section of the Chehalis Basin slightly to the south using the Lauren A2-3 data and Krehbiel (1993b) adapted Ise's interpretation combined with interpretations of DOE 1 and 2 seismic lines. We think that geologic and geophysical controls are far better along our line C-C', particularly in the area corresponding to the eastern part of Lauren A2-3, because data quality on the eastern end of the Lauren profile was very poor. The western part of this line intersects schematic cross sections $A-A^{\prime}$ and $B-B^{\prime}$ (Figs. 7,8).

The geology of the Chehalis basin on the western end of line $C$ - $C^{\prime}$ is similar to that described on lines $A-A^{\prime}$ and $B-B^{\prime}$. Strata are relatively horizontal and cut by a few smaller faults, and a change in stratigraphic nomenclature is shown based on the presence of the volcanic Northcraft Formation. In the eastern part of the Chehalis basin, basinal strata are cut by a series of high-angle faults. These faults appear to line up with both northwest- and northeast-trending structures mapped by Schasse (1987) and Walsh and others (1987) at and west of Bear Canyon. Cumulative eastside-up displacement on these structures is inferred to be about 2,000 to $2,500 \mathrm{~m}$, based on offset of the presumed base of the Northcraft Formation. Faults clearly imaged on DOE line 4 occur at about CDP's (common-depth-point) 12510, 12200, 11940 , and 11300. The gray-scale amplitude plot of the complete profile is shown in

Figure 9-Gray scale amplitude plot of seismic data from DoE line 4.

Figure 9 and details of the data at the CDP's where faults were interpreted are shown in Figure 10. A discussion of processing and display procedures for the seismic data appears in a later section, but we introduce line 4 at this point because of its importance to the stratigraphic interpretation. Between the noted structures on the seismic line, there is a combination of noise interspersed with panels of coherent reflectors. The inferred uplift of Crescent basement within this zone corresponds 


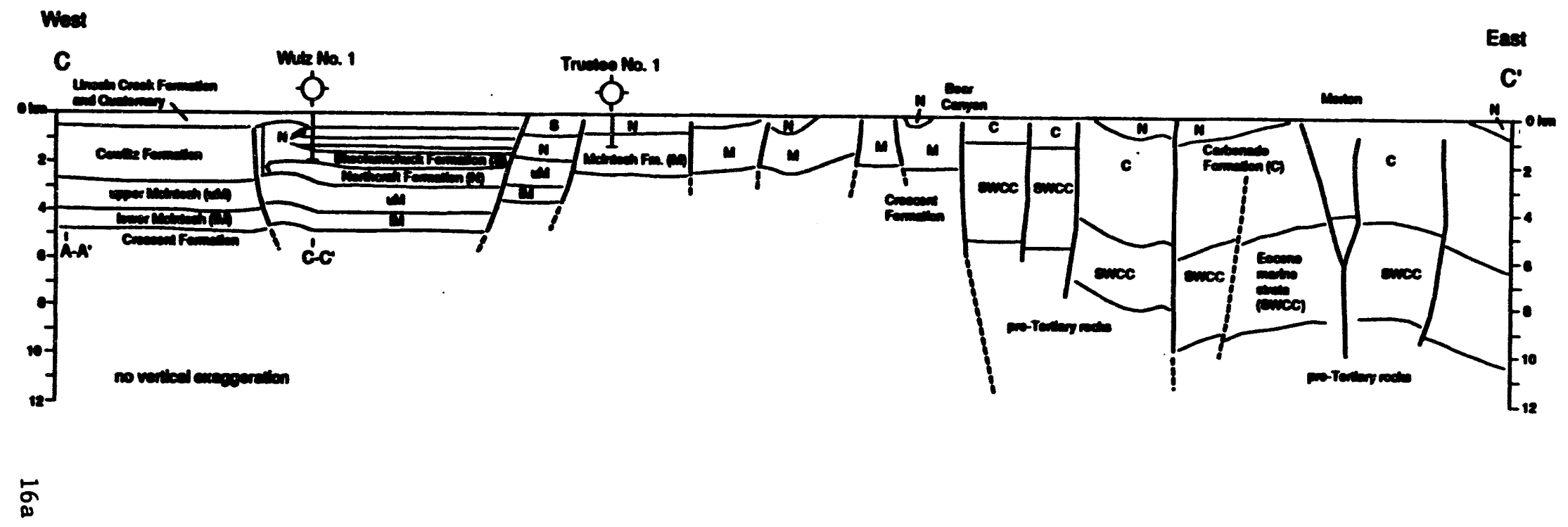

Figure 8 


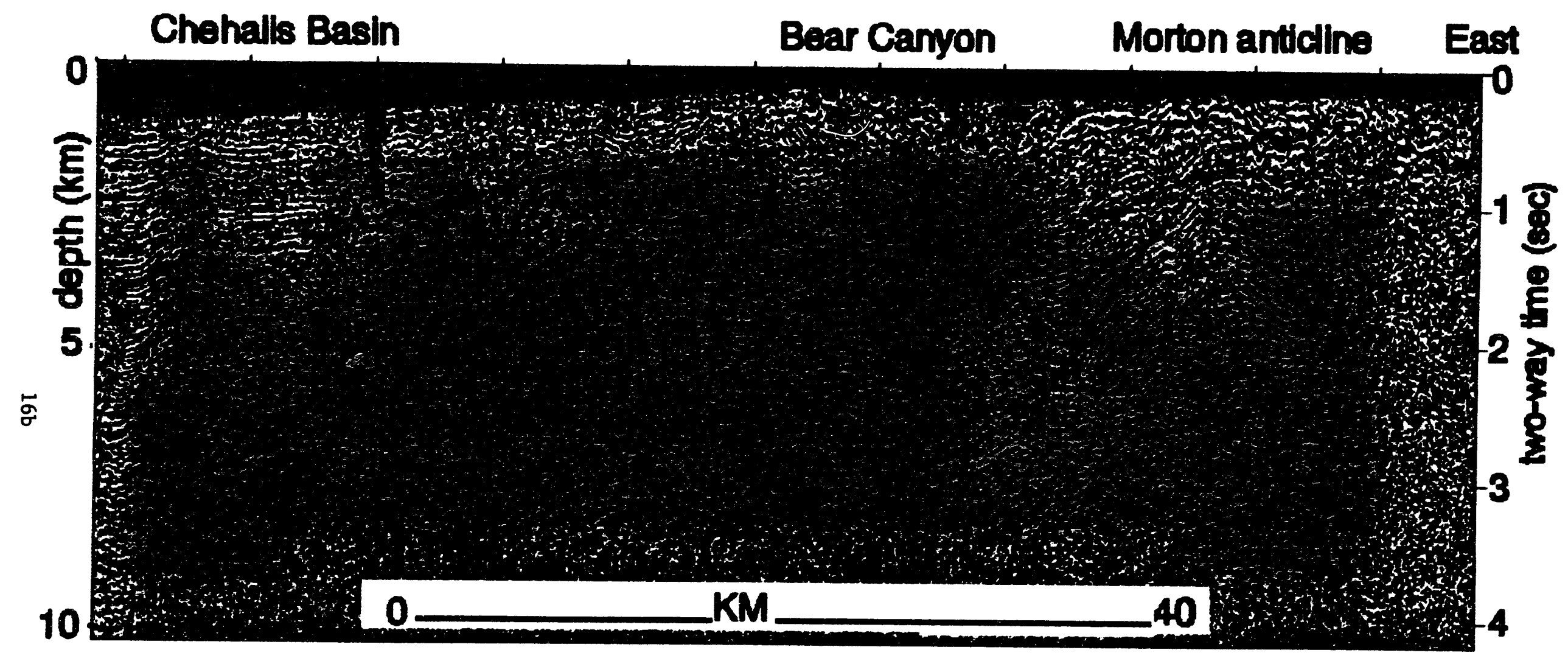

Figure 9 
roughly to the horst-like uplifts of Crescent basement shown by Stanley and others (1992) on their lines $A-A^{\prime}$ (MT sounding 22) and E-E' (MT sounding 13) based on magnetotelluric

data.

East of this network of faults, DOE line 4 images the crustal boundary between uplifted basement of the Chehalis Basin (Crescent Formation) and unknown basement of the main part of the SWCC to the east. This boundary occurs in the Bear Canyon area. From aeromagnetic and gravity interpretation, the Crescent bssement is inferred to extend some distance beneath the Morton antiform in the SWCC, but the actual basement beneath most of the SWCC is unknown. A deep, west dipping set of reflections may image the base of this basement slice, suggestive of a thrust wedge bounding the Morton antiform on the west side. In a later section, we will point out that this thrust is apparently seismically active and may interact in a complex manner with other regional faults.

East of this uplifted margin of the Chehalis Basin, the upper $3-4 \mathrm{~km}$ of strata

Figure 10a,b,c-Details of seismic data at CDP's on Iine 4 referenced in text.

beneath the Northcraft Formation are nonmarine and deltaic in origin (see section on the Morton antiform) and more similar to the Carbonado Formation to the north in the Carbon River antiform (Figs. 2, 3; Gard, 1968) than to the Mclntosh Formation to the west. Strata beneath the Carbonado Formation and above pre-Tertiary basement are inferred marine strata based on magnetotelluric data (Stanley and others, 1992) and are probably contemporaneous with the Crescent Formation (see discussion of the Morton antiform below). These rocks are referred to on the schematic cross section as part of the SWCC.

The net displacement across the transition zone from the Chehalis Basin to the Morton antiform is east-side down, however much if not all of the displacement occurred before deposition of the Northcraft Formation. There are no markers to quantify displacement. Offset of the basement cannot be used because much of the

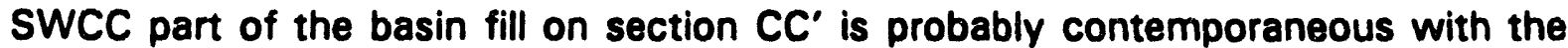
Crescent Formation basement of the western crustal block (Fig. 8). There are numerous faults within the eastern crustal block, some of which have clear reverse or thrust displacement (for example, in the Morton antiform). These faults, which originated as normal faults during Eocene tranștensional deformation and basin subsidence, have no doubt been reactivated throughout the Cenozoic. 


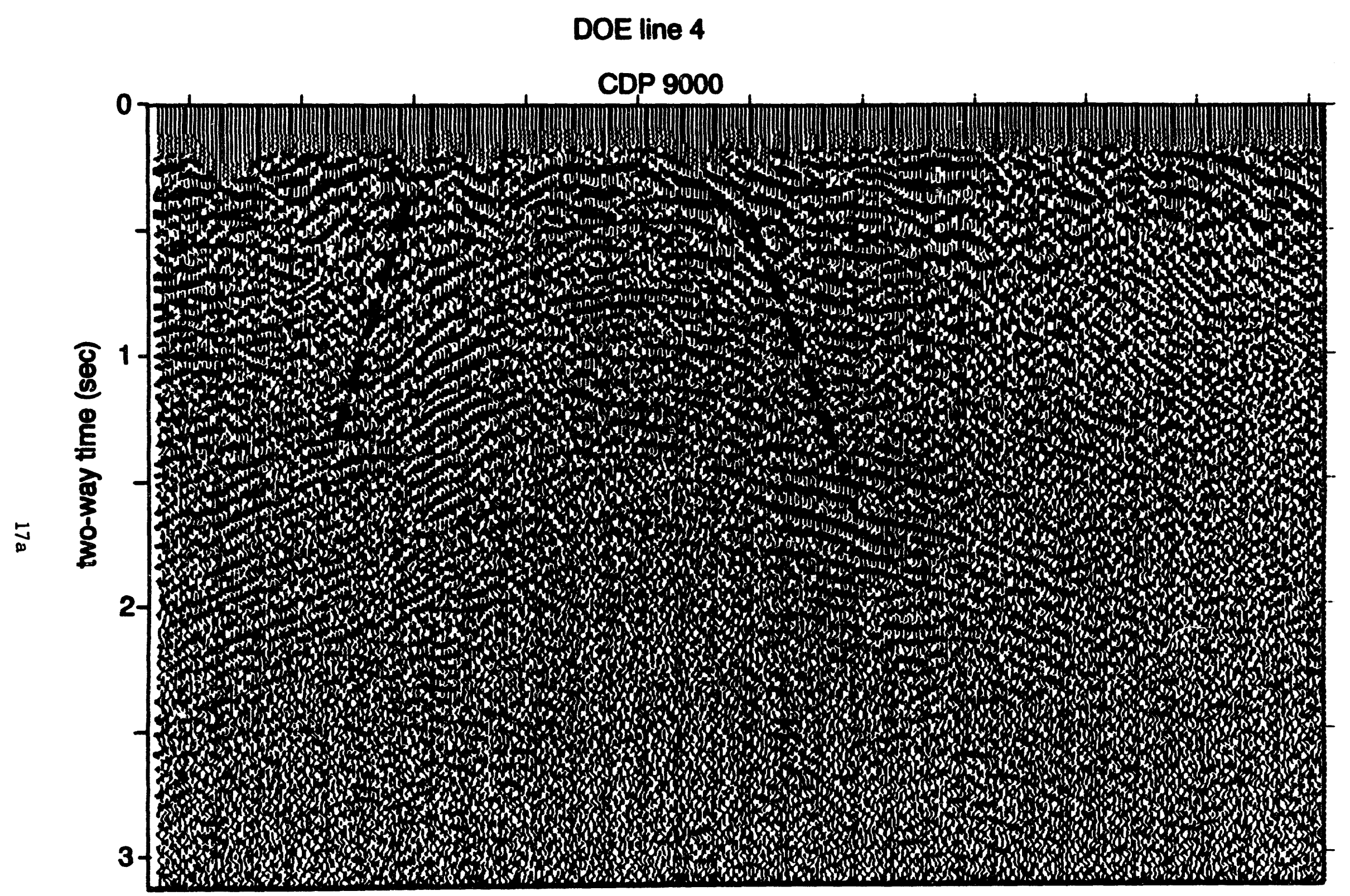

Figure 10 a 


\section{DOE line 4}

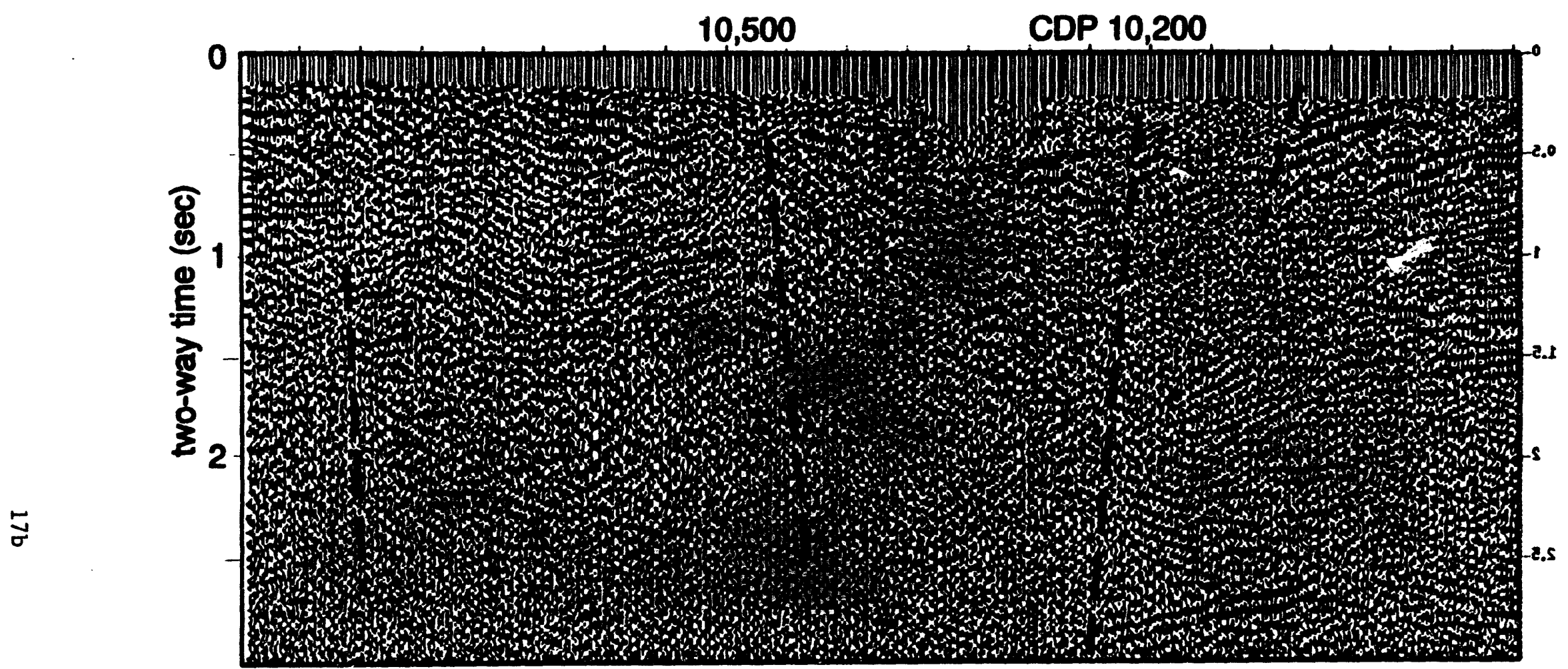

Figure $10 b$ 


\section{DOE Line 4}

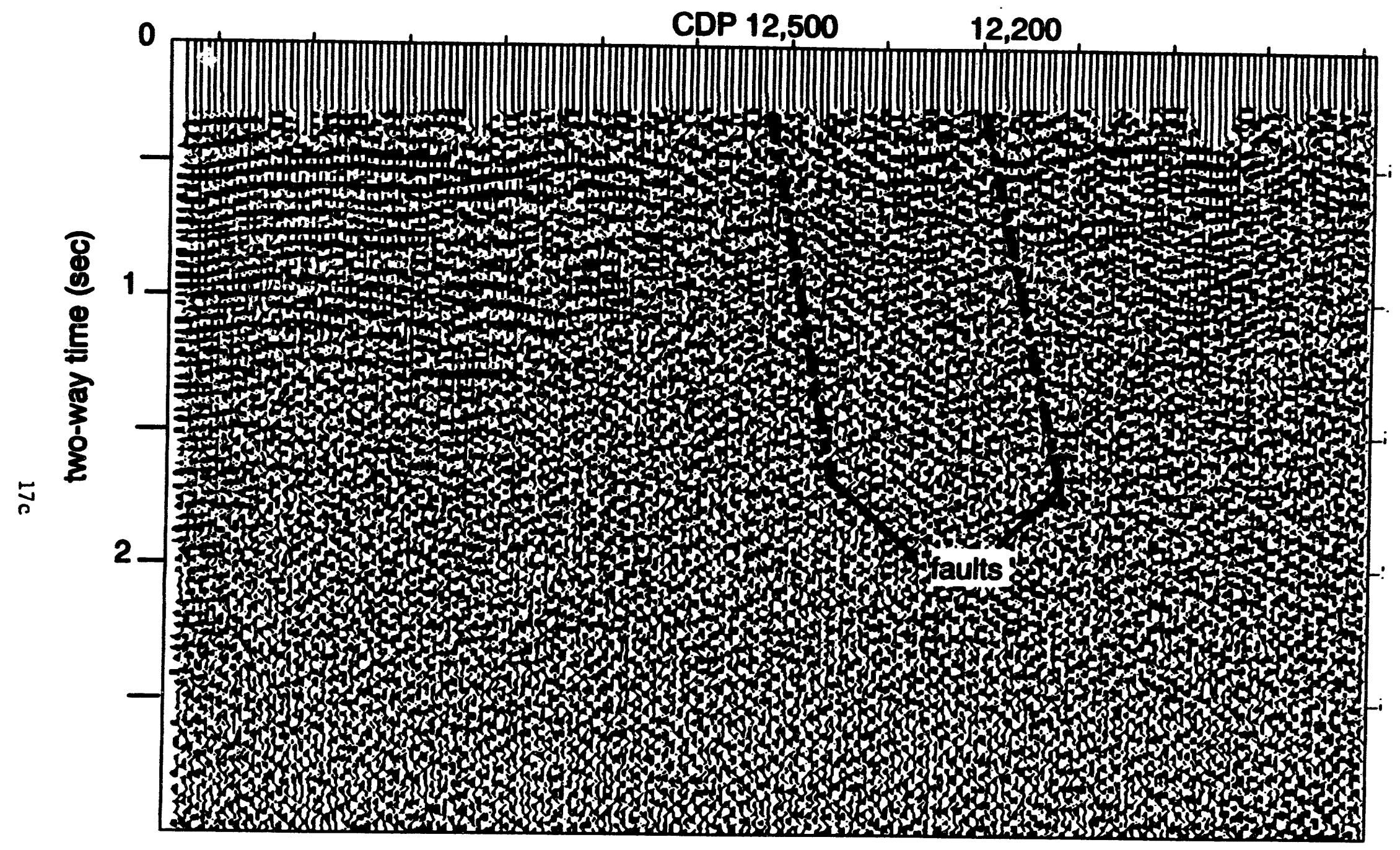

Figure $10 \mathrm{c}$ 


\section{MAGNETOTELLURIC RESULTS}

Three regional MT model cross-sections are shown in Figure 11 and a detailed model of the Morton area in Fig. 12 (locations of profiles in Fig. 2). These profiles represent one-dimensional (layered) interpretations of MT soundings done in the region of the SWCC, but two-dimensional interpretations of profiles $A A^{\prime}$ and CC' have also $^{\prime}$ been completed, as described in Stanley and others (1987). The two-dimensional models provide more accurate constraints on deeper structures, such as the base of the conductive SWCC units (2.5 ohm-m resistivities) on profiles CC' and $A A^{\prime}$ ', but the upper surface configuration of the SWCC is more accurately determined on the onedimensional models. In two-dimensional modeling using finite-element algorithms, it is impractical to model all aspects of the geology in the upper few kilometers because of the requirement for a very large model-grid; thus, most of our discussion will center around details of the one-dimensional models as they relate to structure on the upper surface of the SWCC.

Units of $30-500 \mathrm{ohm}-\mathrm{m}$ from the surface to depths of $5 \mathrm{~km}$ on the model for

Figure 11-NT model sections based upon one-dimensional modeling for profile $\mathrm{AA}^{\prime}(\mathrm{a}), \mathrm{BB}^{\prime}(\mathrm{b})$, and $\mathrm{CC}^{\prime}(\mathrm{c})$ (locations in Fig. 3 ). Interpreted resistivities for the various model layers are indicated by the patterns in the explanation. OLP=olympic Peninsula, CR-Carbon River anticline, NC-North Cascades, $\mathrm{PB}=$ Puget Iowland Basin, MAmorton ant ICline, SY=Skate Mountain anticline, CB=Chehal is Basin, GR=Goat Rocks pluton, CRP=Columbia River Plateau. Numbered, inverted triangles are MT sounding locations. Vertical exaggeration is $1: 1$.

profiles $\mathrm{AA}^{\prime}$ and $\mathrm{BB}^{\prime}$ (Fig. 11 ) largely correspond to volcanic rocks of the Eocene Northcraft Formation the Oligocene Ohanapecosh Formation and the Miocene Stevens Ridge Formation (Vance and others, 1987). Very thick units with resistivities of 100$500 \mathrm{ohm}-\mathrm{m}$, averaging about $150 \mathrm{ohm}-\mathrm{m}$ on the west ends of profiles $A A^{\prime}$ and $\mathrm{CC}^{\prime}$ correspond to gravity and magnetic highs and were interpreted by Stanley and others (1987) to be made up of Siletzia seamounts or other oceanic basalts. Wannamaker and others (1989) interpreted that equivalent oceanic basalts in the Oregon Coast Range had resistivities of about $100 \mathrm{ohm}-\mathrm{m}$ or slightly less. Rocks with resistivities of 500-5000 ohm-m that reach within $2 \mathrm{~km}$ of the surface on the east end of profiles $A A^{\prime}, B B^{\prime}$, and $C^{\prime} C^{\prime}$ correspond to Tertiary plutons and North Cascades crystalline 


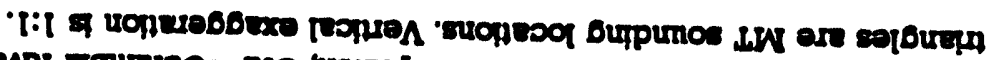

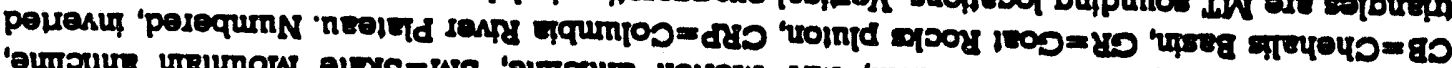

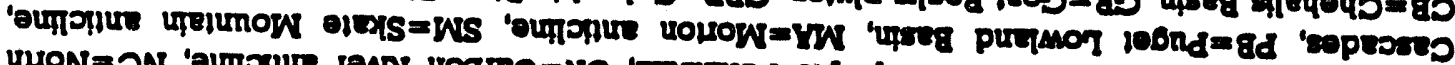

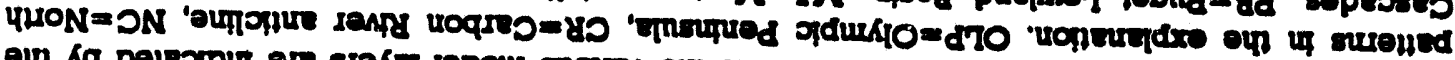

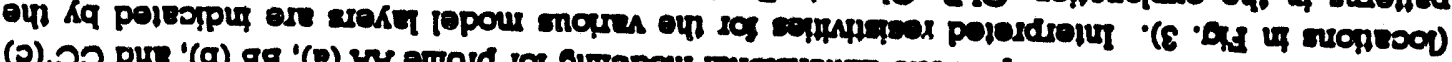

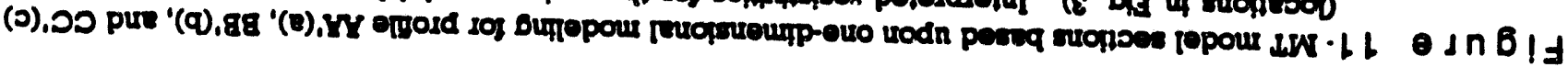

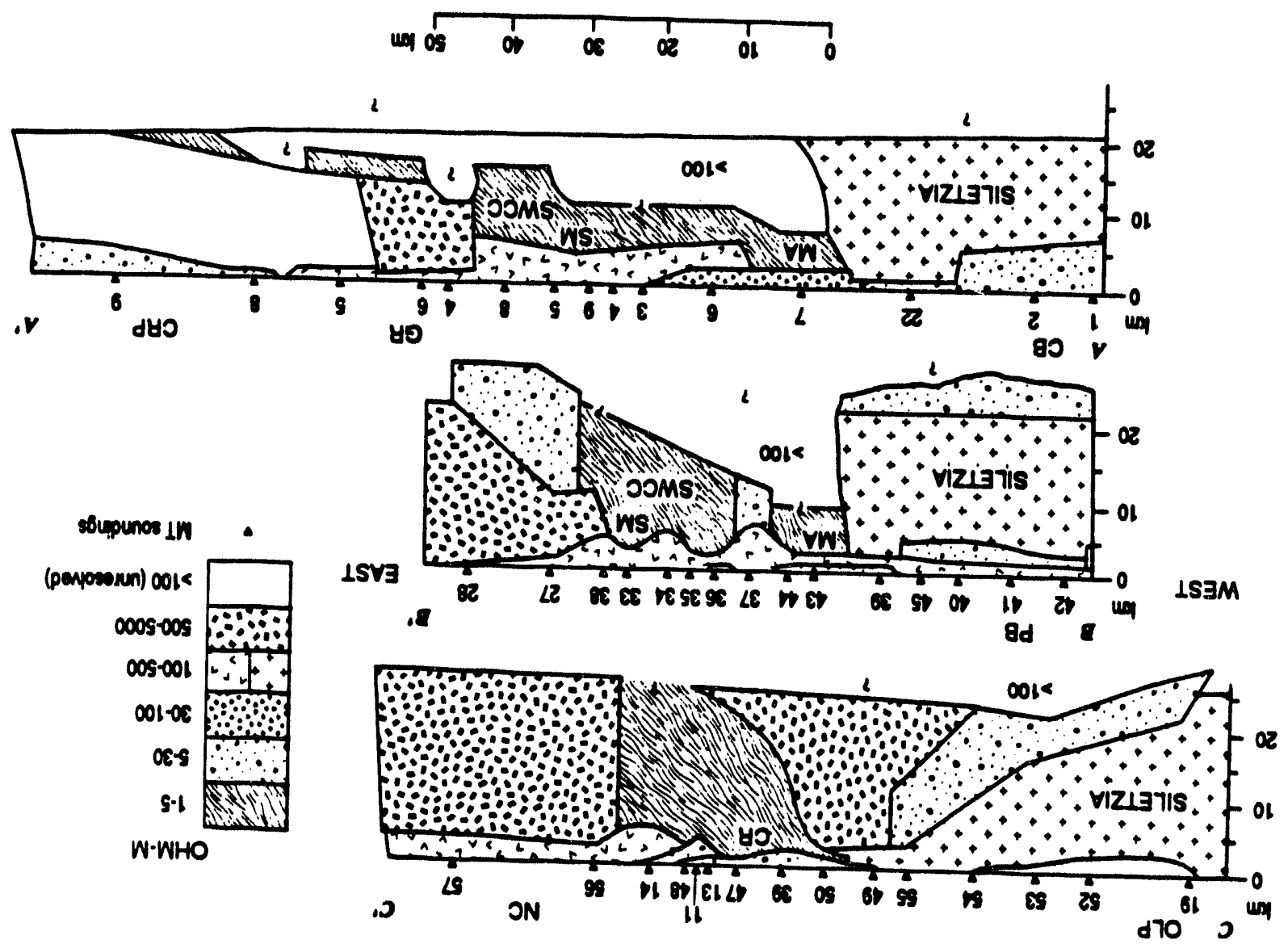


rocks. It is not clear what high resistivity units beneath soundings B55 to B39 on profile CC' signify; they may represent intrusions connected with Siletzia or younger intrusions, probably of Oligocene or Miocene age. The most significant feature of the three MT profiles is the thick, conductive section with resistivities of 1.5 (averaging about 3) ohm-m. The top surface of this conductive package (SWCC) occurs at depths of only $1-3 \mathrm{~km}$ near the axis of the Carbon River (profile $C C^{\prime}$, station 47). Skate Mountain (profile BB') and Morton (profile $\mathrm{AA}^{\prime}$, stations 3 and 7 , and profile $\mathrm{EE}^{\prime}$ ) antiforms. The conductive rocks also appear to crop out west of Morton in the Bear Canyon area where they are represented by marine sandstones and siltstones of the McIntosh Formation (Fig. 8). Because of the large thickness and low resistivity of the conductive section, all of the MT soundings did not penetrate to its lower boundary, but enough did so to enable approximate modeling of the lower surface. Resistivities beneath the conductive section are poorly determined, but must be greater than 100 ohm-m. It is apparent from the MT sections of Figure 11 that the SWCC units are thicker and less laterally extensive on profile $C C^{\prime}$ than to the south on profiles $A A^{\prime}$ and BB'; this geometry is interpreted to be due to greater horizontal compression on the north end of the proposed sedimentary sequence.

A layered model for detailed MT profile EE' is shown in Figure 12. The thick conductive (3-6 ohm-m) section on the west end of the profile becomes shallower near Bear Canyon, where Eocene marine rocks of the McIntosh/Carbonado Formation crop out. The Mclntosh/Carbonado Formation (Hedges, 1949; Snavely and others, 1951) is overlain by nonmarine Puget Group sedimentary units $(20-80 \mathrm{ohm}-\mathrm{m})$ and Northcraft Formation volcanic rocks $(100-300 \mathrm{ohm}-\mathrm{m})$. We interpret the section of conductive rocks (3-6 ohm-m) as contemporaneous with, and older than, the Carbonado Formation (see cross-section in Fig. 8) and equivalent to the $1.5 \mathrm{ohm}-\mathrm{m}$ section on the models of Fig. 11. The high-resistivity (>1000 ohm-m) units beneath sounding 13 may correspond to Oligocene to Miocene intrusive units that crop out $12 \mathrm{~km}$ west of Bear Canyon (Waish and others, 1987), but probably is related to massive mafic units

Figure 12-Magnetotelluric 1D-model cross-section EE' (Fig. 2). Numbers in the cross-section are interpreted resistivities for the model layers and numbered, inverted triangles are MT sounding locations. Vertical exaggeration is 1:1. Iocation of profile shown in Fig. 2.

in the core of the uplifted Crescent basement. The relatively steep contact portrayed between the $1000 \mathrm{ohm}-\mathrm{m}$ unit and conductive (assumed Mcintosh Formation) units reflects uplift of the Crescent Basement along a fault also mapped in the seismic reflection data (Figs. 8,9 ). 


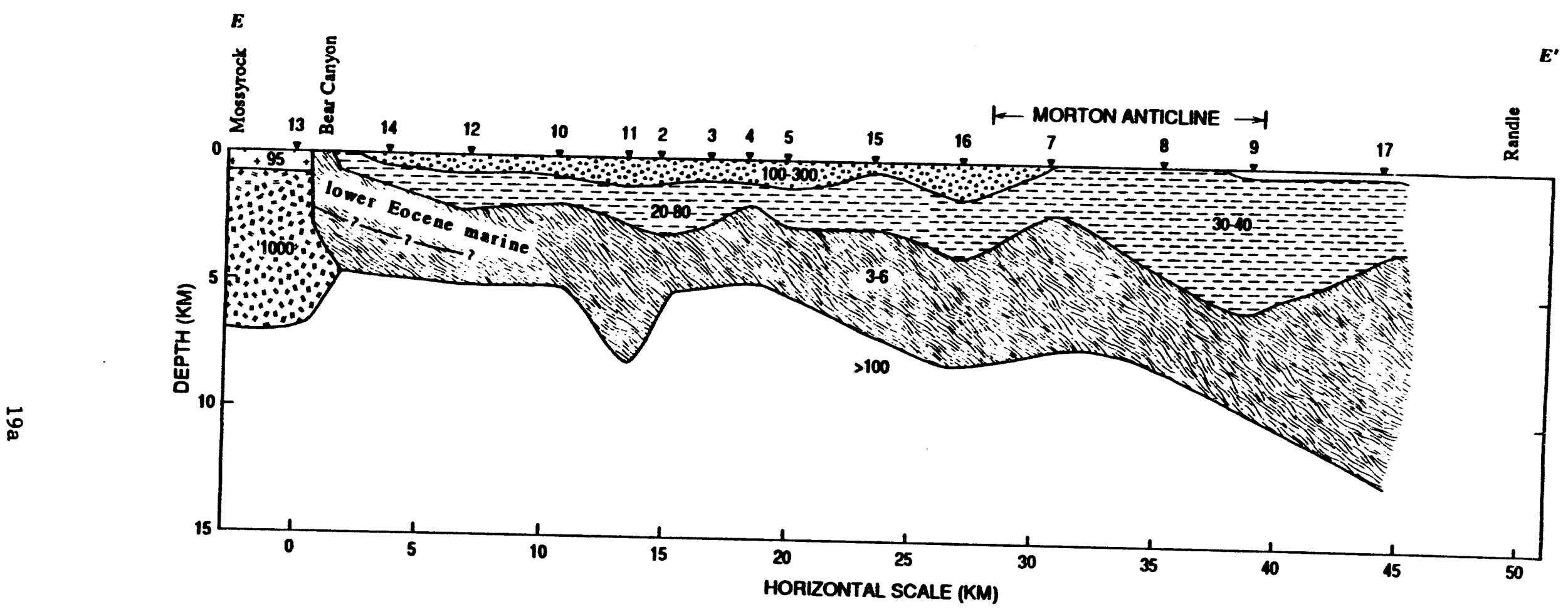

Figure 12 


\section{Gravity and Magnetic Data}

Analysis of gravity and magnetic data have played a key role in understanding the nature of the SWCC and related geological units, such as Siletzia, as reported in Stanley and others (1987) and Stanley and others (1992). The mafic units of Siletzia are readily mapped with both gravity and magnetic data and Finn (1989, and in Stanley and others, 1987) has used computer models to calculate the regional boundaries of this units, as well as its thickness and physical properties. The magnetic data are especially useful because of the large magnetization contrasts provided by the Eocene and younger volcanic rocks and Crescent Formation with the sedimentary units, which are very low in magnetization. It was found by that the extension and details of the key antiforms in the region could be mapped with magnetic data, because of the thinning of volcanic rocks over their crests (Stanley and others, 1987; 1992); key faults were also evident in the magnetic data, possibly due to the effects of alteration and offsets of highly magnetic units. For these reasons, a high resolution aeromagnetic survey was acquired under DOE funding (Abrams,

Figure 13-High resolution aeromagnetic map for swcc region from Abrams (1992).

1992). The data and some of the details regarding faults and antiformal structures are shown in Figure 13. The Skate Mtn. and Morton antiforms are clearly outlined in the

Figure 14-Geologic cross-section compiled by Phillips and others (1989) with an aeromagnetic profile obtained approximately along the seismic profile $51-53$ shown in the upper part of the figure. Bold lines are key reflection packages noted by stanley and others (1992).

data, as are several key faults, and vents for the Northcraft Formation. Further details are better investigated with profiles from the survey data, as indicated in Figure 14, where an aeromagnetic data profile is displayed from a transect that parallels the DOE reflection lines 1,2 , and 3 across the SWCC. The accompanying geological section (from Walsh, 1989) reveals that the details of the magnetic data are probably related to the thickness of the volcanics, as well as topography where these magnetic rocks were closer to the aircraft level. 


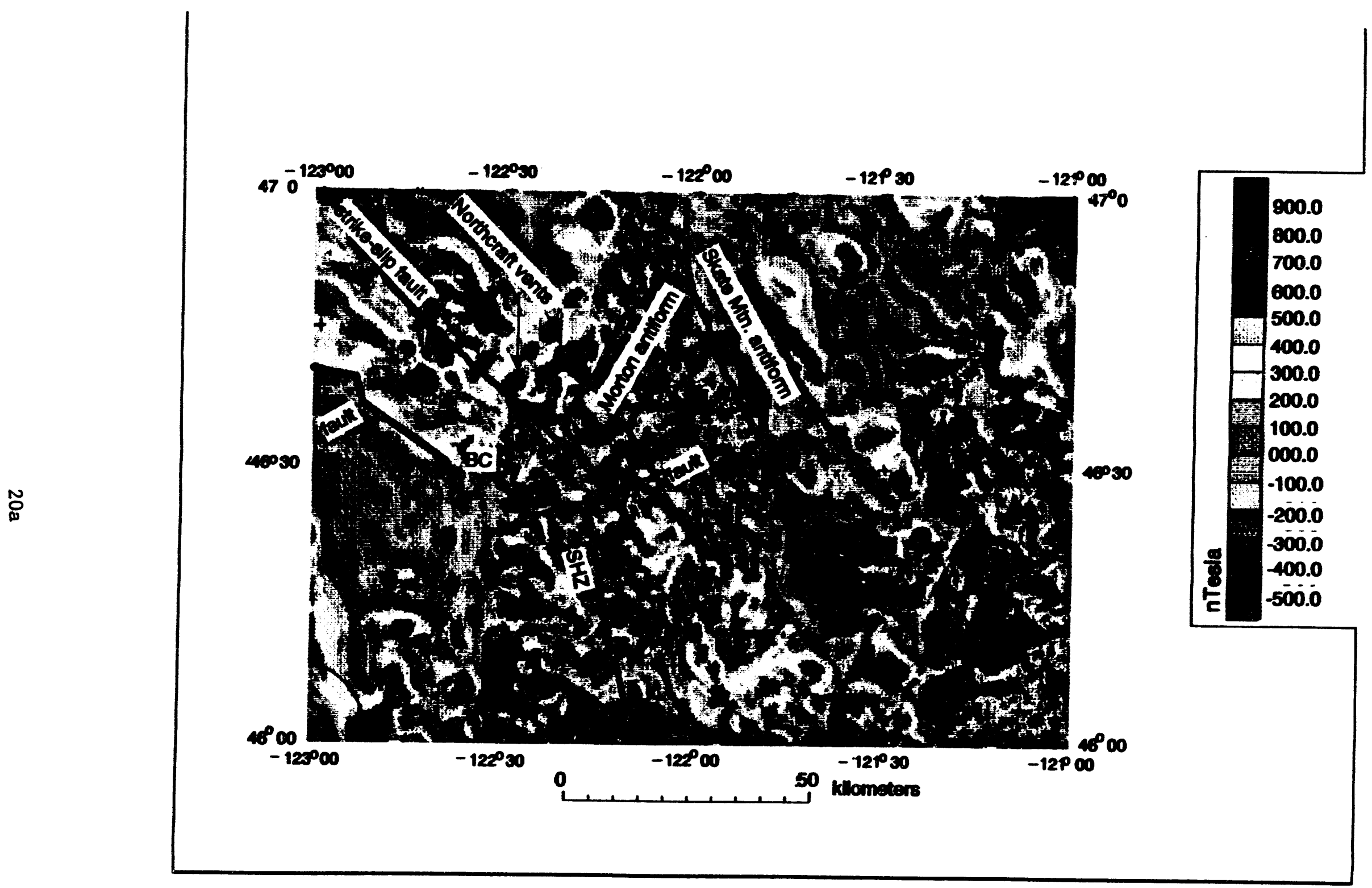

Figure 13 


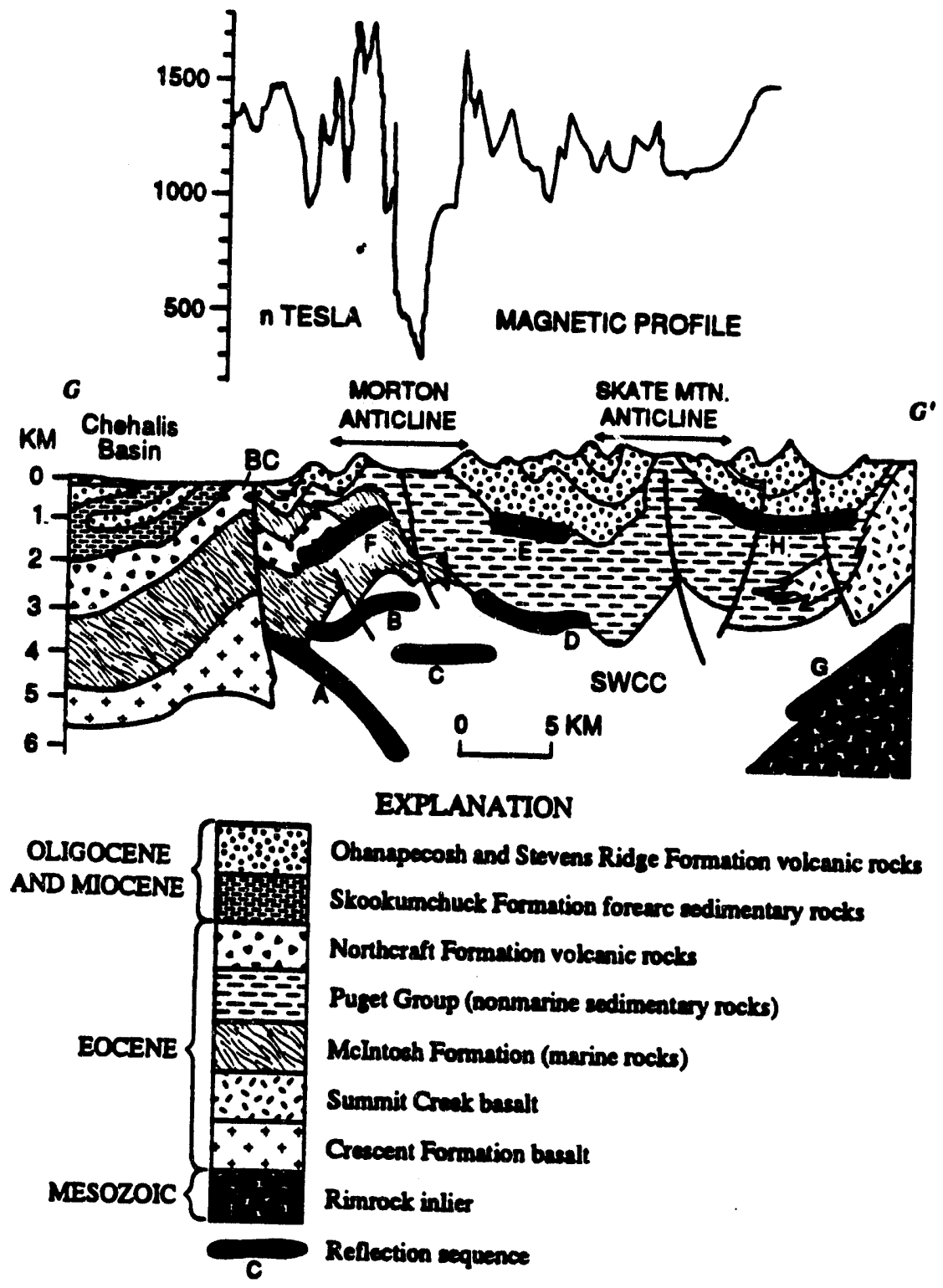

Ceologic crosis-eection compiled by Phillipa and others (1889). Added for purposes of this paper are main seismic redection events (bold dotted linea, $\mathrm{A}-\mathrm{H}$ ) from foure 6. We have added Crescent Formation haser are main ceismic Cheilalis Basin according to our tinterpretation and that of Ise (1883). Faults (bold colid lines) are from Phillipe and others figure.

Figure 14 


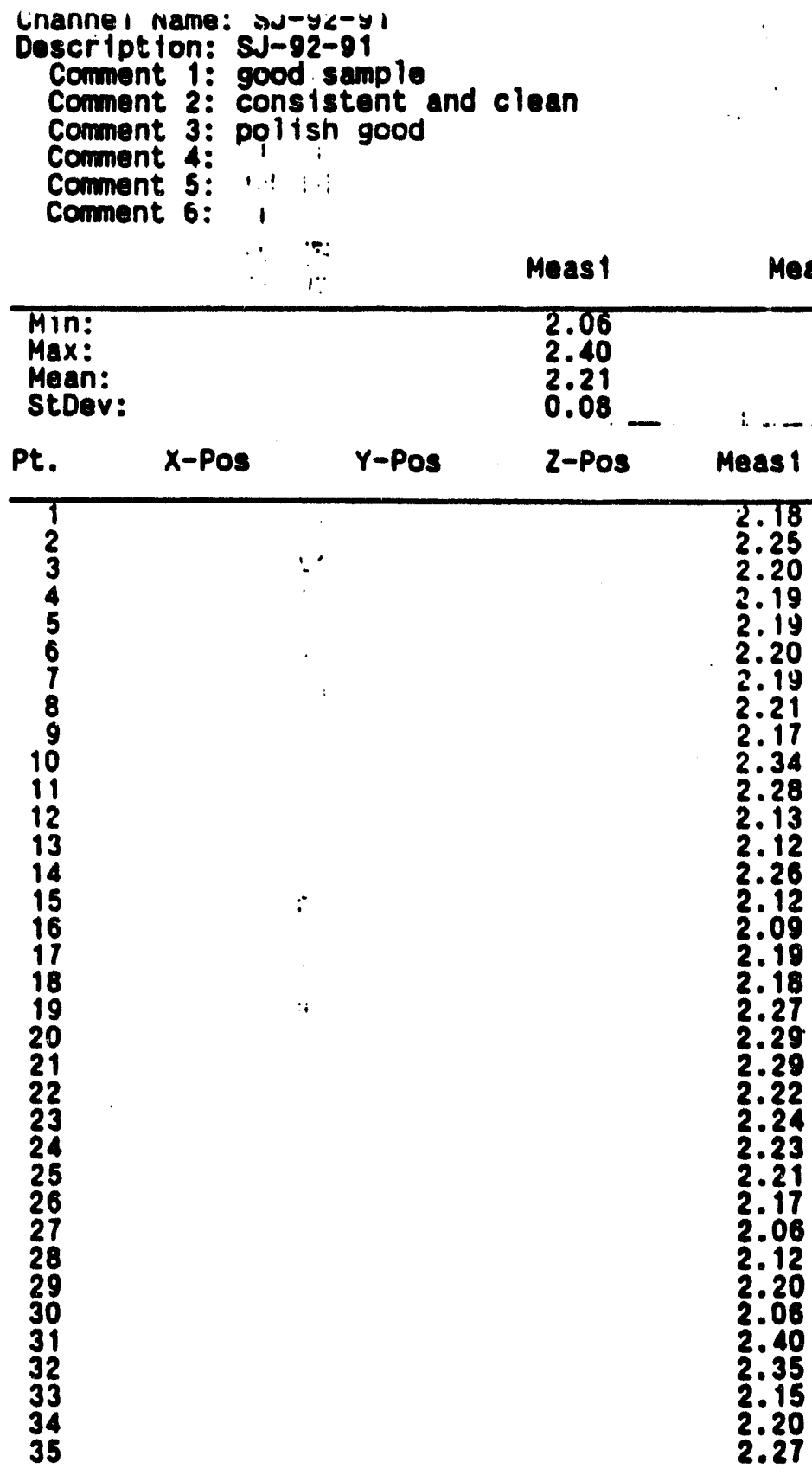

$\because$ 


\section{LITHOLOGY OF ROCKS IN THE SWCC}

We have hypothesized (Stanley and others, 1992) that the conductive units of the SWCC are composed largely of marine sedimentary rocks based upon several observations:

(1) Interpreted resistivities of the SWCC units are about $2.5 \mathrm{ohm}-\mathrm{m}$ in most locations. These resistivity values are very typical of marine shales and shaley sandstones, as evidenced in MT soundings and well logs from Tertiary basins to the west of the SWCC region. Resistivities of nonmarine and transitional-marine sedimentary units are in the range 15$60 \mathrm{ohm}-\mathrm{m}$ in the few deep wells in the SWCC region, including the Phillips State No. 1 and Shell Thompson wells. Even some shales, such as in the marginal-marine Carbonado Formation in the bottom of the Phillips State No. 1, are not as low in resistivity as Tertiary marine units found further to the west (Cowlitz Formation, for example), as determined by wells logs and MT soundings in the Mist gas field and Chehalis basin. We assume this is due to the fact that the Carbonado Formation sampled has been flushed of marine brines in the highly disturbed environment of the Carbon River anticline and the Cowlitz Formation occurs in a stable basin environment where marine waters are still in place.

(2) Shallow depths to the conductive rocks correlates well with the location of antiforms cored with transitional marine facies of the Puget Group and marine units such as the Mclntosh Formation. In addition, the conductive rocks appear to surface near Bear Canyon (Fig. 4,12) coincident with outcrops of the Mclntosh Formation. There is broad evidence in recent studies for an extensive marine depositional period during and before the Mclntosh Formation deposition (see discussion below on the Morton antiform).

(3) Ise (1985) used reflection data from a profile paralleling the Toutle River in the Chehalis Basin to demonstrate approximately $11,000^{\prime}$ of additional reflective rocks beneath the bottom of a deep (10,000' TD) well near Toutle. The well had bottomed in the Mclntosh Formation. Ise interpreted these reflectors to be sedimentary rocks of the Mclntosh and older formations, and assumed about 5000' of this unmapped section to be the McIntosh Formation and the remainder of the sections to be older units. 


\section{ALTERNATE LITHOLOGIES FOR SWCC UNITS}

\section{Nonmarine Sediments}

North and east of the SWCC region, a number of fault-bounded basins are filled with thick nonmarine sediments (Johnson, 1985; Evans and Johnson, 1989). These fault-bounded, or pull-apart (Mann and others, 1983) basins are interpreted to have been caused by oblique slip on the Straight Creek, inferred Puget (Johnson, 1984a), Leavenworth, Entiat, and Eagle Creek fault systems ( Tabor and others, 1984; Johnson, 1985; Evans and Johnson, 1989). Syntectonic fill of the Swauk, Naches, Roslyn, Chuckanut, and Chumstick Formations in these Washington pull-apart basins is up to $6 \mathrm{~km}$ thick and consists of conglomerate, sandstone, shale, fanglomerate, and ironstone (Tabor and others, 1982). Resistivities in these nonmarine sediments are believed to be greater, in most instances, than the 2-5 ohm-m measured for the SWCC and too high to be the cause of the low resistivities in the SWCC. The Swauk, Naches, and Chumstick Formations are contemporaneous with the Puget Group, but strictly nonmarine. There is no surface evidence for marine sediments in any of these pull-apart systems, but older marine sequences related to such basins probably form part of the SWCC. However, some of the thick, nonmarine complex may have been subsequently invaded by marine fluids, especially in the near vicinity of the coastline. Such post-deposition, subsurface invasion by seawater may explain the high salinities recently (Hurst, 1991; Hurst, oral comm., 1993) found in the Chuckanut (nonmarine) Formation in the Bellingham Basin flanking Puget Sound (Fig. 2).

\section{Geothermal Fluids}

It is highly probable that low resistivities in deeper parts of the SWCC are partially due to geothermal fluids. Increased ionic mobility due to high-temperature geothermal fluids can increase the conductivity of sedimentary rocks by several hundred percent. The behavior of resistivity with temperature and salinity is well documented (Olhoeft, 1985). Resistivities of porous rocks such as those of the Swauk and Chumstick Formations can be lowered to the 1-3 ohm-m range with formation salinities of 30,000 ppm or greater; such salinities might be present in these nonmarine units if playa conditions existed during phases of basin development, deep brines were forced upward into the section, of if the sedimentary section was subsequently invaded by seawater. For the porosities of less than $10 \%$ that would be typical for sandstones at depths of greater than $5 \mathrm{~km}$, a combination of temperatures of about $250^{\circ} \mathrm{C}$ and salinities of $10,000 \mathrm{ppm}$ would be required to produce the resistivities of less than $5 \mathrm{ohm}-\mathrm{m}$ measured in the SWCC. Shale-rich parts of the Puget Group such as the Carbonado and Spiketon Formations (Buckovic, 1979) would have to be influenced less by temperature or increased salinities to be relatively conductive (as required by the SWCC) due to presence of clay minerals in the rocks.

The effect of temperature on resistivity in the SWCC region has been considered thoroughly because of the presence of three major volcanic centers: Mount Rainier, Mount St. Helens, and Mount Adams. Heat flow in the Washington Cascades has been studied by Blackwell and others (1985), who found that temperature 
gradients in the region of the SWCC are about $30^{\circ} \mathrm{C} / \mathrm{km}$; thus, temperatures of 200$300^{\circ} \mathrm{C}$ might exist in units of the SWCC at depths of $7.9 \mathrm{~km}$. On the east side of the SWCC region, near Packwood (Fig. 3), higher gradients of $>50^{\circ} \mathrm{C} / \mathrm{km}$ have been mapped by Bainett and Korosec (1989); thus, even higher subsurface temperatures are expected on this part of the cross-section. However, we believe that the correlation of highs on the top of the SWCC with antiforms that bring Tertiary marine units to shallower depths is an indication that the main cause of the upper part of the SWCC is lithologic in nature. The Phillips State No. 1 well is instructive to study, since it is located only about $30 \mathrm{~km}$ from Mount Rainier. Although the pervasive zeolitization of the lower section of the well probably indicates past geothermal activity, there is no evidence of abnormal formation temperatures in this $4.2 \mathrm{~km}$ hole. We believe the present thermal effect of the volcanos in the southern Washington Cascades is limited to the area very near them, as characterized by more extensive heat flow data from the Oregon Cascades volcanoes (Blackwell and Steele, 1983). The correspondence of the top surface of the SWCC to the structure of antiforms in the region argues against the concept of increased temperatures being the primary cause of low resistivities in the anomalous region, because we would expect low resistivities to become shallower to the east where subsurface temperatures are higher. However, resistivities in the deeper parts of the SWCC are very likely influenced by increased temperatures, especially in the area near Packwood and eastward where Barnett and Korosec (1989) have mapped high thermal gradients.

Stanley and others (1990) have discussed the role of similar high thermal gradients in the Oregon Cascades (where heat flow is even higher) in producing deep crustal conductors. Such conductors in Oregon are pseudo-horizontal and occur regionally at depths of $11.20 \mathrm{~km}$. There is a clear association of this Oregon horizontal conductor with midcrustal seismic velocities of $6.4-6.6 \mathrm{~km} / \mathrm{s}$. This association and other factors were used to suggest the cause of the regional conductor as metamorphic fluids and partial melt. There is no way to distinguish such a thermallyrelated conductor from the conductor that occurs in the southern Cascades, except for the factors of morphology of its upper surface, correspondence to seismic reflectors, and relationship to tectonic features. The most recent MT profile completed was done across the south flank of Mt. Rainier las part of a USGS Volcano Hazards project), largely within the National Park using a backpack MT system. The west end of the profile (XX', Fig. 3) started on Eocene transitional marine rocks of the Carbonado Formation in the Skate Mtn. antiform and the east end of the profile was beyond the axis of the Cascades volcanos. This profile has not been completely modeled, but indicated that the SWCC units dip almost eastward almost monotonically to depths of about $25 \mathrm{~km}$, where they disappear on the east. There is no apparent shallowing near Mt. Rainier, suggesting that our assumption that the conductor is largely caused by a specific lithology and pore fluid is correct; higher geothermal gradients do not appear to affect the depth to this anomalous conductor.

Authigenic Minerals

It is possible that desper parts of the SWCC may correspond to altered volcanic 
rocks that are conductive due to development of authigenic minerals such as zeolites and smectites. We have earlier mentioned the presences of zeolites below 7200 feet in the Phillips State No. 1 well (Fig. 2). Volcanic flows with high percentages of ash generally become quite conductive when hydrothermally altered, because the high silica content and large surface-area of ash allows rapid conversion to zeolites and smectites. These authigenic minerals are highly conductive due to their ability to maintain high ion-transfer capability. Electrical geophysical studies in Newberry volcano, Oregon and Long Valley caldera, California, by Fitterman and others (1988) and Stanley and others (1976) show that tuffaceous volcanic flows can have resistivities as low as $2-8 \mathrm{ohm}-\mathrm{m}$. These resistivities are approximately equal to those in the SWCC and although the Tertiary volcanic rocks studied electrically in the region have resistivities of about $30-500 \mathrm{ohm}-\mathrm{m}$, this does not exclude older, more ash-rich flows at depth as a constituent of the SWCC. The development of zealites and smectites can lower the resistivities of marine and nonmarine sedimentary rocks, as well as volcanic rocks. The extensive zeolites in the lower part of the Phillips State No. 1 lower resistivities, but not dramatically, probably because they mainly fill fractures; in ash-rich volcanic or sedimentary rocks where the ash is in depositional layers, the continuous, layered distribution of the authigenic minerals is more effective in lowering resistivities.

\section{Pre-Tertiary Conductive Rocks}

Conductive rocks older than Tertiary could be the cause of the SWCC, because unmetamorphosed marine shales and mudstones of any age are generally quite conductive (2-20 ohm-m) and graphitic metasedimentary rocks can be very conductive (1-5 ohm-m, Stanley, 1989; Stanley and others, 1990a). The only pre-Tertiary rocks mapped in the region of the SWCC are those in the Rimrock Lake inlier (Ellingson, 1972; Miller, 1989). The Rimrock Lake inlier (Figs. 2,3) consists of a Jurassic igneous complex of trondhjemitic to gabbroic rocks, some metamorphosed to amphibolite grade, and a Jurassic-Cretaceous tectonic melange of mainly arkose and mudstone. Somewhat similar rocks, generally occurring as phyllites, are found along the western margin of the North Cascades (Fig. 2). MT soundings on the melange portion of the Rimrock Lake inlier indicates high ( $>200 \mathrm{ohm}-\mathrm{m}$ ) resistivities at depths greater than $0.5 \mathrm{~km}$, suggesting these units are thin and are probably underlain by more metamorphosed versions of the melange or by intrusive rocks. On the western flank of the North Cascades, other Mesozoic metasedimentary units have resistivities of 200-600 ohm-m, thus are probably not a cause of the SWCC.

\section{Summary of Lithologies}

In the preceding discussion regarding lithology, we outlined reasons for our preferred interpretation that conductive rocks in the SWCC correspond to Eocene, and possibly older, marine sedimentary rocks. These marine sedimentary rocks could have been deposited as part of a forearc basin/accretionary prism or in a marine pull-apart structure. Slightly less probable for the proposed lithology of the SWCC units, in our view, is that of highly alterad volcanic rocks. Ranking third in probability for the SWCC 
lithology is a section of nonmarine sediments beneath the lower part of the Puget Group. Of lowest probability for the SWCC lithology are Mesozoic metasedimentary units like those in the Rimrock Lake inlier or other older rocks. High temperature geothermal fluids and possibly even partial melt may play a role in reducing resistivities in the deepest part of the SWCC, but the distribution and attitude of the highly conductive rocks are such that we believe that these factors are less impcrtant than lithologic ones, at least for hydrocarbon exploration depths.

\section{SEISMIC REFLECTION DATA}

\section{Acquisition and Processing}

In order to study details of the SWCC, a deep reflection profiling program was initiated in the region. The survey was done along six profiles (Figs. 1,3 and Appendix B) by Geophysical Systems, Inc. under contract to the U.S. Department of Energy using a 1000-channel, sign-bit system (Zoback and Wentworth, 1986; Gimlin and Smith, 1980). Five vibrators with a peak force of $27,240 \mathrm{lbs}(12382 \mathrm{~kg})$ were used with a modified downsweep from $8-32$ or $8.48 \mathrm{~Hz}$. Vibrator point spacing ranged from $40 \mathrm{~m}$ to $120 \mathrm{~m}$. Receiver-group spacing was $30 \mathrm{~m}$ on line 1 and $20 \mathrm{~m}$ on the remainder of the DOE seismic lines. After the initial test survey involving line 1, raytrace models of deep structure appearing in the data was done to more effectively plan the later surveys across the SWCC. Data processing generally followed the flow chart below: 


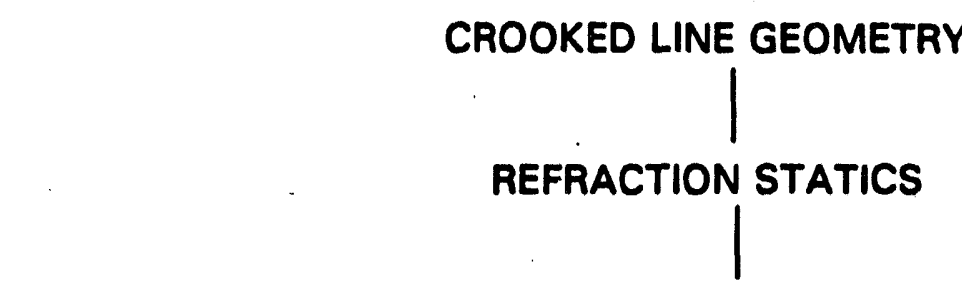

SPHERICAL DIVERGENCE AND INELASTIC ATTENUATION CORRECTION

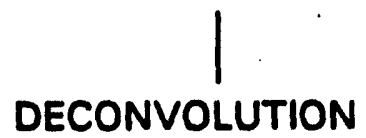<smiles>CC</smiles>

CDP SORT

I

VELOCITY ANALYSIS

RESIDUAL STATICS CALCULATION

VELOCITY ANALYSIS

|

RESIDUAL CALCULATION

1

COMMON MID-POINT STACK

1

F-X SPATIAL DECONVOLUTION

PHASE CORRECTION TO ZERO PHASE

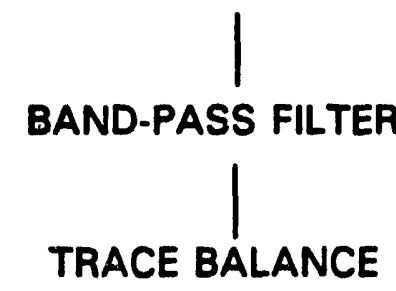

Data were stacked with a maximum of 256-fold coverage, following the steps above with two or mcre passes of residual statics and including horizontal 
deconvolution (F-X deconvolution) for some of the data (lines 1-3). The latter technique is a predictive method to correlate events from trace to trace and produces a minimum numbers of artifacts when compared to the coherency filtering sometimes applied to poor-quality reflection data. Crooked line geometry corrections were important because of the irregular profiles, and this correction failed to clean up some of the data, notably on line 6.

In addition to the Vibroseis surveys, minor testing was done with dynamite sources; these latter tests proved promising, but the difficulties and costs involved with dynamite surveys in this region of high tourism made extensive dynamite surveying impossible. Crustal scale seismic refraction surveys have also been completed by the USGS along a north-south profile across the northern pert of the SWCC, but the data were very poor over the volcanic covered area and interpretations have not been completed to date

Shotpoint and CDP (common-depth-point, Sheriff, 1984) locations for the seismic survey are contained on the CD-ROM (Zilman, 1992). The complete shotpoint data set is shown on Figure 3, with each tenth shotpoint labeled. The decade numbers on Figure 3 can be correlated with the tables in Appendix $C$ to derive actual shotpoint numbers. The CDP path for each of the seismic profiles are quite complicated because of the non-linear nature of the profiles, thus the seismic sections actually follow a ground path that cuts across the bends in the highways used for the data acquisition and the CDP track is very wide, averaging a great deal of the subsurface. Because of the degree of geological complexity, this CDP averaging is the cause of the some of the poor data quality, and only a dense 3D survey would adequately image the complex structures. An approximate 3D survey was constructed in the region of the Morton antiform using the CDP's from lines 1, 2, 4, and 5 , but because the survey had not been acquired as a 3D survey, the decimation in fold caused by selection of 3D CDP bins caused the data to be incoherent below 1 sec travel time. Thus, the constructed 3D data along the nine lines was not useable for study of structural aspects of the Morton antiform, as had been hoped. A possible approach to conducting surveys like that across the SWCC in future studies in the region or in similar areas might be the use of wide-line-profiling (WLP) as described by Michon (1993). This method uses a sequence of shotpoints offset from a linear profile to produce a modified 3D survey at a much lower cost than a normal 3D survey. The resulting data is processing in terms of calculated dip for coherent horizons. The advantage in this method is that complex sets of reflection sequences can be separated into events from unique horizons. It seems to us that the irregular access roads normally found in mountainous regions like that of the SWCC would lend themselves well to this type of modified 3D survey. We intend to investigate the possibility of applying the WLP processing methods to selected portions of the Washington DOE data.

Velocity analysis for the stacked record sections was done using automated normal moveout (NMO) and dip-move out (DMO) routines, tested by common midpoint (CMP) stacking (Sheriff, 1984; Cordier, 1985). It was found that this autornatic velocity analysis was not completely satisfactory due to the geological complexity that 
made the CMP stacks of poor quality in some sections. Considerable fine tuning of the automatic picks was done to try to improve the data coherency. This generally amounted to fixing the velocities over time bands and along trace spans to remove some of the variability introduced by the automatic velocity analysis. This appeared to help the data coherency in several instances, especially on lines 1 and 2 where most of this adaptive velocity picking was done.

Grau (1993) has addressed the problem of obtaining seismic velocity information from reflection data in complex regions. He defines a complex region as

Figure 15-Averaged velocity profile from several key wells west of the swCC (solid line), with average velocity profile from stacking velocities in the Morton antiform area (dashed Iine), and velocity versus depth curves for Eocene shales from Gregory (1977).

one in which CMP stacking and post-stack migration make if difficult or impossible to conduct conventional processing operations. He recommends a variety of techniques to assist in complex regions, including pre-stack migration. In spite of the obvious difficulties in obtaining coherent reflection horizons and deriving good velocity models, pre-stack migration was not attempted on the Washington data because of the very large computer expenditures required for this process on 1000 channel data. Such processing might improve portion of the data, but no tests have been done to date.

The actual velocities for most of the survey are poorly known because of the lack of wells in the SWCC region. Only wells from the nearby Chehalis Basin were available for sonic log studies. Sonic logs from several of these wells are included in Appendix $C$. The best of these logs for velocity analysis is the relatively deep Thompson No. 1 (location in Fig. 4). This sonic log is provided in Appendix $C$ and is shown in Figure 15 along with stacking velocity profiles from the automatic picker at four selected CDP's. The log in Figure 15 has been scaled vertically to a velocity of 12,000 feet/sec to display with the stacking velocities. The sonic log indicates velocities in the Lincoln Creek/Skookumchuck marine sandstones and shales of 813,000 feet/sec down to a depth of about $8000^{\circ}$ where volcanic flows of the Northcraft Formation have higher velocities of 14,000-19,000 feet/sec. Below the Northcraft, the Mcintosh Formation has velocities of about 15,000 feet/sec. The exponential increase in velocity with depth in the sedimentary rocks reflects the compaction of the sandstones and shales and increased cementation with depth. Older sedimentary rocks will also have higher velocities than younger ones, reflecting the time rate of compaction and metamorphism. Higher temperatures will also increase the metamorphism of sedimentary rocks, generally leading to higher velocities. All of these factors make it difficult to assign accurate velocities to deep sedimentary units in the study area. However Gregory (1977) has used empirical formulas to attempt to quantify the effects of fluids, depth, and age on the velocity 


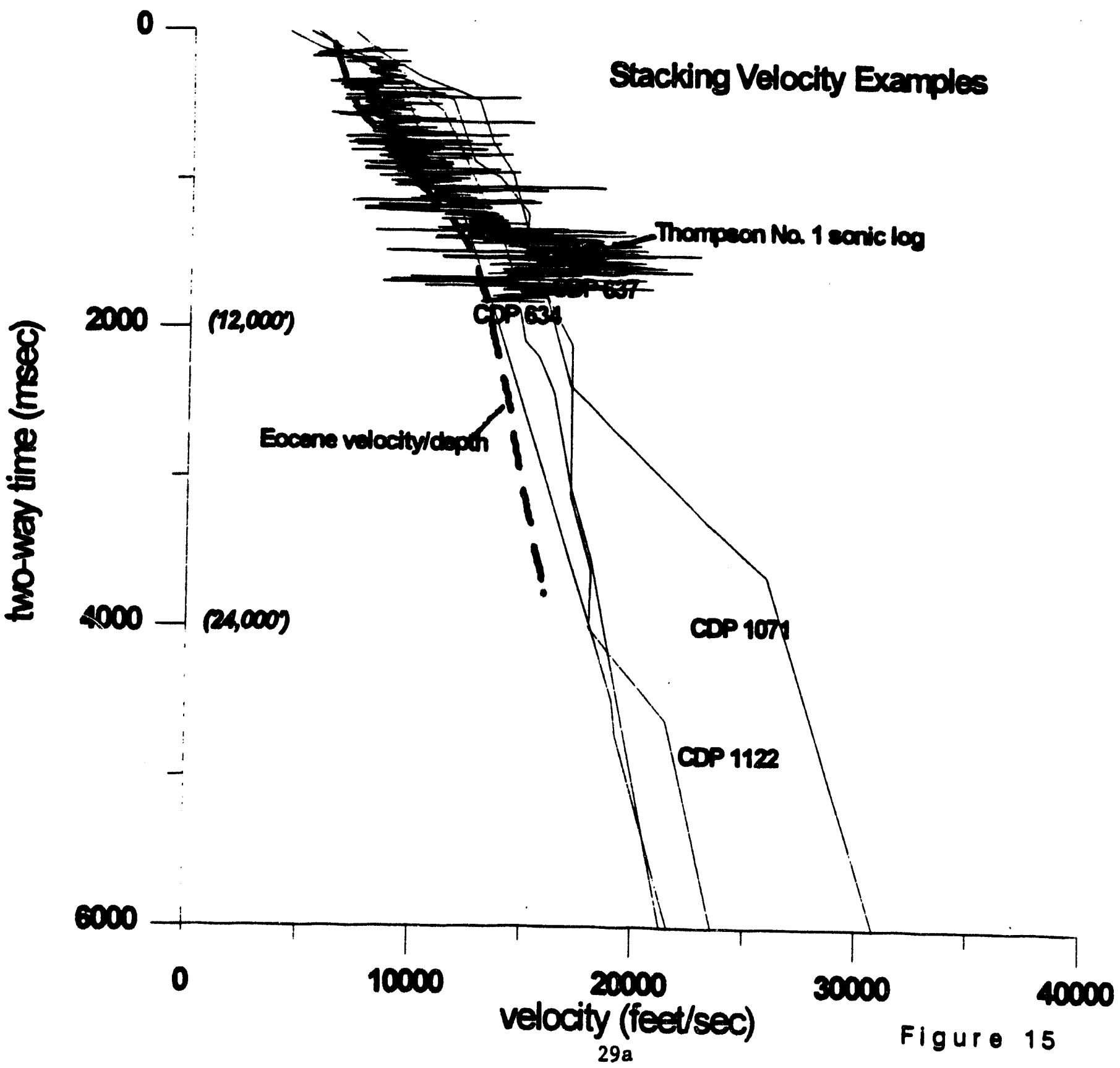


of sandstones and shales. The dashed curve in Figure 15 shows a plot of velocity/depth using the formulas of Gregory (1977) for an Eocene shale. The fit to the upper part of the Thompson well is reasonable (much of the section is Oligocene, rather than Eocene) and the deeper part suggests that some of the automatic velocity picks from the processing software are reasonable, but others are clearly out of line. For the remainder of our discussion, we will assume a velocity of $5 \mathrm{~km} / \mathrm{s}$ for approximate depth conversions in the seismic sections, since our main interests are in the deeper parts of the data that correlate with the SWCC. Exact depths are not at issue in this report, but the tectonic and stratigraphic interpretation of the seismic data is the important factor.

\section{Reflection Records Sections and interoretations}

Additional processing of the DOE reflection data was made possible with the aid of the CD-ROM developed by Nick Zilman (USGS Open File Report 92-714) which contains all of the CDP and location data. Software developed at the Colorado School of Mines Center for Wave Phenomena (Stockwell, 1993) called SU facilitate processing and display of the seismic data. This software operates under the $X$ windows environment on UNIX workstations and does many of the processing and display operations available with commercially available software packages. In addition, several innovative migration and 2D/3D modeling routines are available. For the seismic sections discussed in this report, we have fine-tuned the original data provided by the processing contractors in minor ways through band-pass filtering of some of the data and additional agc and trace balancing. As discussed in a later section, we have also begun 3D modeling of line 3 data to investigate sideswipe or out-plane-reflections that appear to influence the data. The data in following sections are displayed as gray-scale (256 level) amplitude plots of the processed CDP files.

A gray-scale amplitude representation of the stacked CDP record section from combined seismic lines 1 and 2 is shown in figure 16. An expanded section of a portion of the profile in the Morton anitform is shown in figure 17. The data were recorded to 15 seconds, but only the upper 6 seconds of data are shown because no coherent events were observed in the remainder of the record. The data quality is generally not adequate for interpretation at travel-times greater than 3-4 seconds. This degradation in data quality was caused by traffic noise, poorly-defined velocity functions, the presence of surface volcanics, structural complexity, and non-linear survey routes. Regardless of a lack of reflections below 3-4 seconds at increasing time, this survey represents the first reflection data suitable for intermediate-depth (down to about $8 \mathrm{~km}$ ) structural interpretation from the Cascades. A standard exploration seismic profile across the central part of the Chehalis Basin was described by Ise (1985), but the DOE survey represents the first public domain deep-reflection data for the Washington Cascades.

We have drawn three lines on the section that represent the possible level in the reflection section of key geological horizons, (1) the base of Eocene-Miocene volcanic rocks, (2) the base of nonmarine units of the Puget Group, $(3)$ the base of the SWCC units mapped with MT soundings. The volcanic units can be distinguished partially by 
the highly variable reflectivity, with examples of very high reflectance in the upper 1 second, and by the meshing, or irregular shingling of individual reflectors. The largely nonmarine, deltaic units of the Puget Group (largely Carbonado Formation on this section) can be recognized by a variety of mildly sigmoidal, divergent reflectors characteristic of delta front/delta plain environments (Brown and Fisher, 1979, Table 1, p. 42). The units identified as related to the SWCC are probably Mclntosh Formation equivalent marine units as discussed in an earlier section with the variable (low to high) reflectivity, parallel to slightly divergent stratiforms, and high continuity suggestive of distal fan delta deposits (Brown and Fisher, 1979, Table 1, p. 42).

Hunt Oil Company has applied for a permit to drill a $15,000^{\circ}$ hydrocarbon test well in section 1 just east of the town of Morton. This location is indicated on Figure 14 and the well will sample key parts of the SWCC and packages of bright reflections indicated on the seismic section. The bright, somewhat horizontal reflection at about 1.8s travel time may be related to fluid anomalies such as overpressured brine or gas/water interfaces. However, with the inability to study the phase relationships of the seismic data with Vibroseis, we had no opportunity to evaluate this possibility. The large contrasts in reflectivity may be related to uncomformities in the assumed

Figure 16-Gray scale amplitude plot for DOE line 1 and 2 combined. The location of a proposed $15,000^{\prime}$ drill test by Hunt 0 il $c o$. is also indicated.

mostly marine units, but more likely is related to changes in subsidence rates and sediment supply for the distal fan delta system. Another factor in rapid lateral changes in reflectivity may be the thinning of the volcanics over the Morton antiform, which would result in better energy penetration in the region of the brightest reflections.

Detailed plots of data from seismic line 1 are shown in Figure 17 across the east flank of the Morton antiform. The layered basement reflections may be attributable to Crescent Formation basalt flows and interbedded sediments. These reflections suggest a rather monotonic dip down to travel times of about 4 seconds. The section represents unmigrated results, as most of the migration experiments for all of the seismic lines were not very satisfactory becasue of a the highly variable velocity field and poor reflection quality. Locally some good final migration sections were obtained, but for the most part, the unmigrated data proved more useful for stratigraphic interpretations. In the case of the dipping reflections on the right side of Figure 16 at 2.5-4 seconds travel time, migration pulls the most steeply dipping portion back to the left (west), but the sense of structure is the same. Also on this figure, a significant strike-slip zone is evident in the abrupt transition between two major reflective zones at 1.2 seconds on the right to three zones at similar depths on the right. This interpreted strike-slip zone probably is the continuation of the St. Helens zone (SHZ), and pcssibly connects to the fault interpreted in the magnetic data 
$9 \operatorname{\theta esn} 6 ! t$

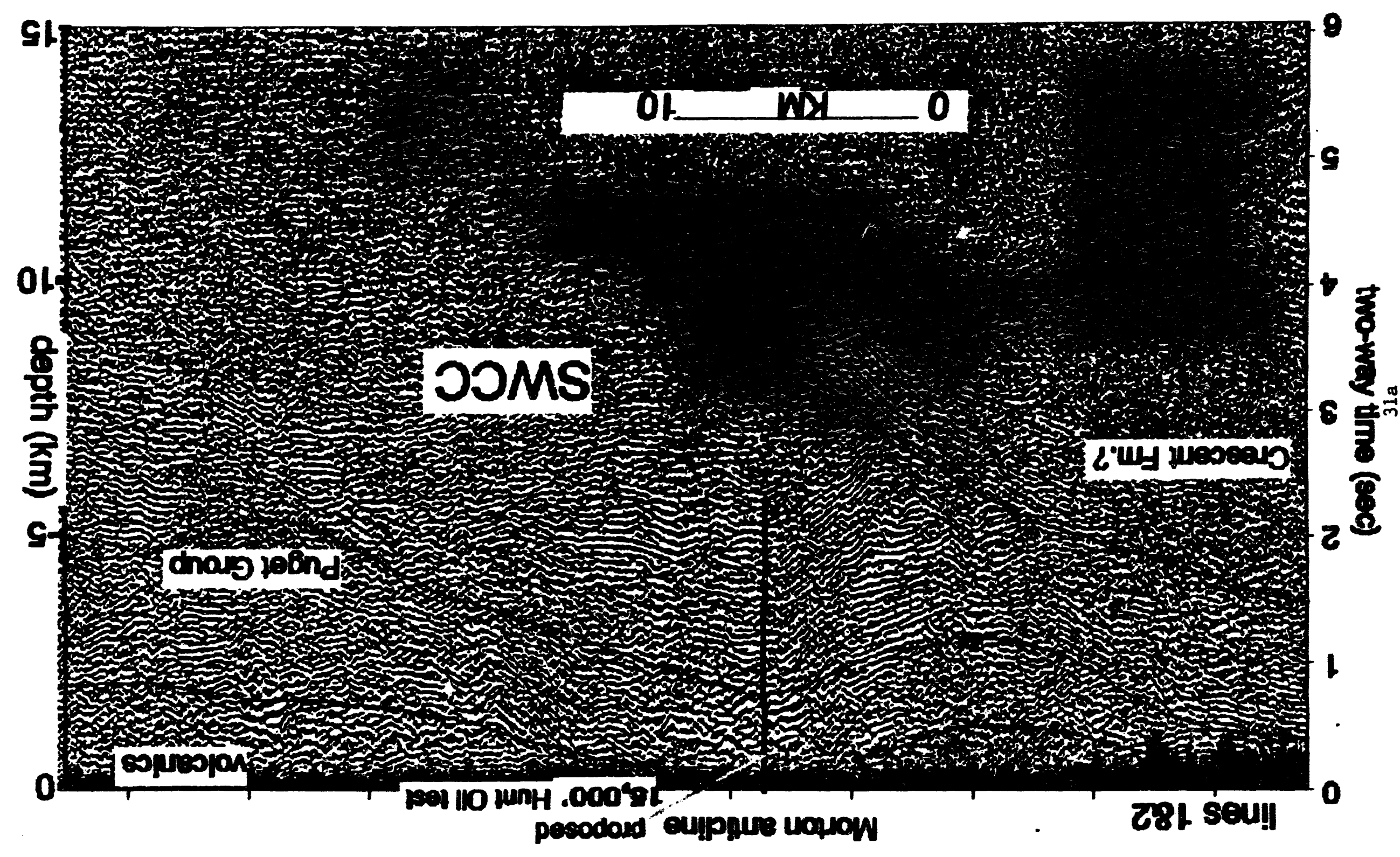


of Figure 13.

Gray-scale, amplitude data from DOE seismic line 3 are shown in Figure 18. This section indicates a number of interesting features not observed in such quantity on the other five profiles. An interpreted deep volcanic basin filled with Ohanapecosh

Figure 17-Expanded plot of DOE line 1 for yorton antiform. An obvious strike-slip zone is indicated by the symbols.

Formation flows occurs on the east end of the line (just right of Packwood location) extends to travel times of $1.9 \mathrm{~s}$. Velocities in the volcanic rocks are probably similar to those of the Northcraft Formation indicated on sonic logs (Appendix C) of $>16,000$ feet/sec. With these velocities the bottom of the volcanic pile is interpreted to be at about $15,000^{\prime}(4.6 \mathrm{~km})$. The thickening. of the flows in the center of the basin suggests that their was syndeposition of the volcanics during downdropping of the basement. A west dipping fault can be interpreted in the volcanics just below the "0o" in the word Packwood. Part of the reason for interpreted this complete section as Ohanapecosh volcanic rocks is that the westward extention of the reflectors is discordant from a dipping section of reflectors beneath that we interpret in the next paragraph to be Eocene sedimentary rocks. . However, there are minor outcrops of Eocene mudstones in the town of Packwood that would be hard to fit in with the interpretation of the reflection data. These mudstones may be landslides that came from local uplifts related to the large Oligocene/Miocene intrusions in the Packwood area (both north and southeast, Fig. 3). Outcrops of Eocene mudstones have been noted on the tops of the Tatoosh pluton just south of Mt. Rainier. In addition, geological mapping by Don Swanson, USGS (oral comm., 1993), in this region indicates a regional east-west fault that follows the Cowlitz River valley, which also shows up on the aeromagnetic data in the western Cowlitz valley (Fig. 12). These complications make it difficult to have confidence in a simple interpretation of the seismic data, but the data themselves appear relatively simple in the upper 1-2 seconds.

Below the interpreted volcanic basin, a thick monoclinally folded section of reflectors that we interpret to be associated with Eocene sedimentary rocks extends to travel times of nearly 4 seconds, where several west-dipping reflections are associated with the pre-Eocene basement. The sedimentary rocks are assumed to be nonmarine units like those that crop out in the Summit Creek area just northwest of the end of seismic profile and to Puget Group units like the Carbonado to the west (Fig. 3). Several of the deep, linear reflections on the east end of the profile were interpreted as multiples by Stanley and others (1992). There is a repetitive character to the last two events at about 4 and 5 seconds travel time, respectively; however,

Figure 18-Gray scale amplitude plot of data for DOE line 3. 


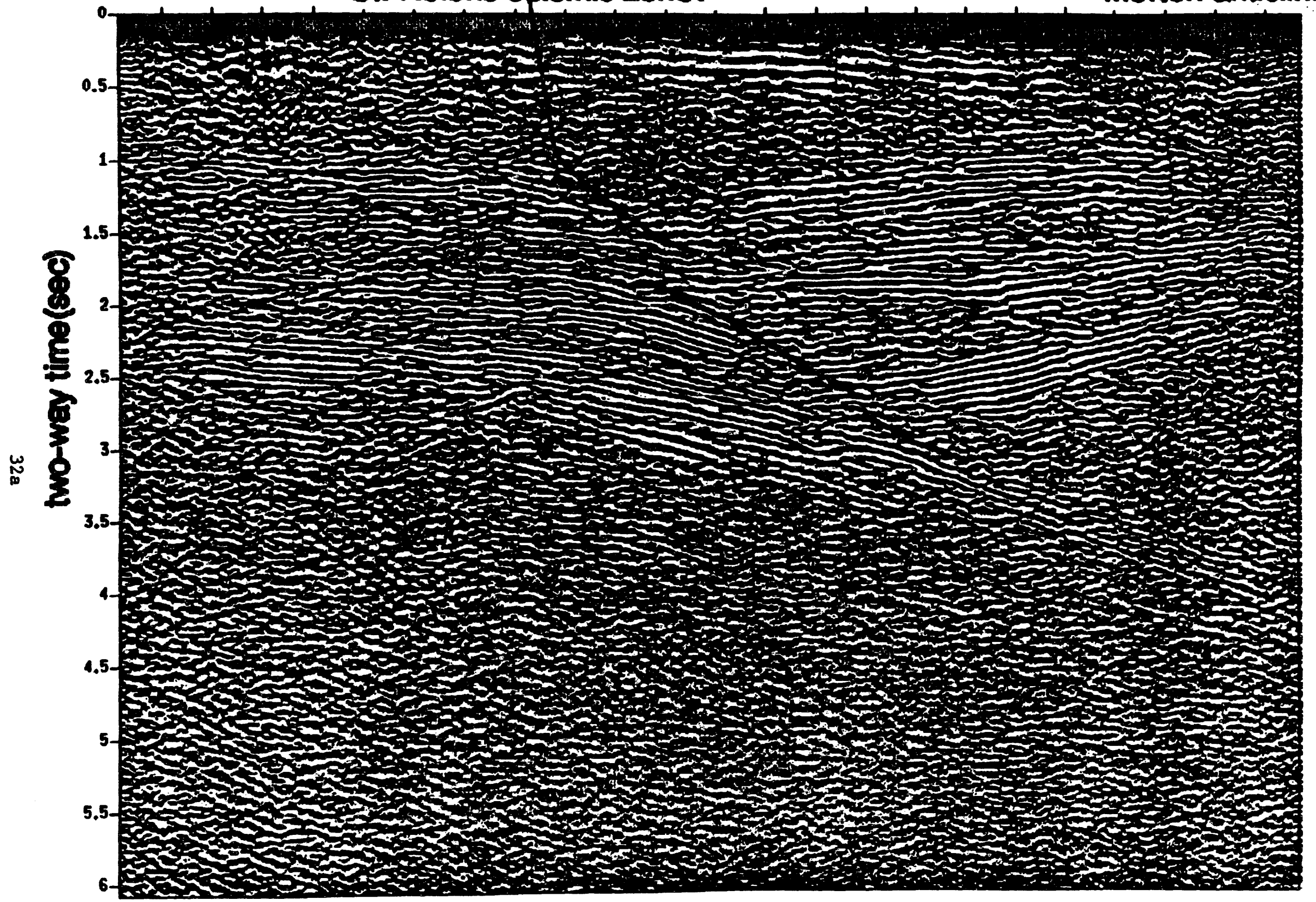




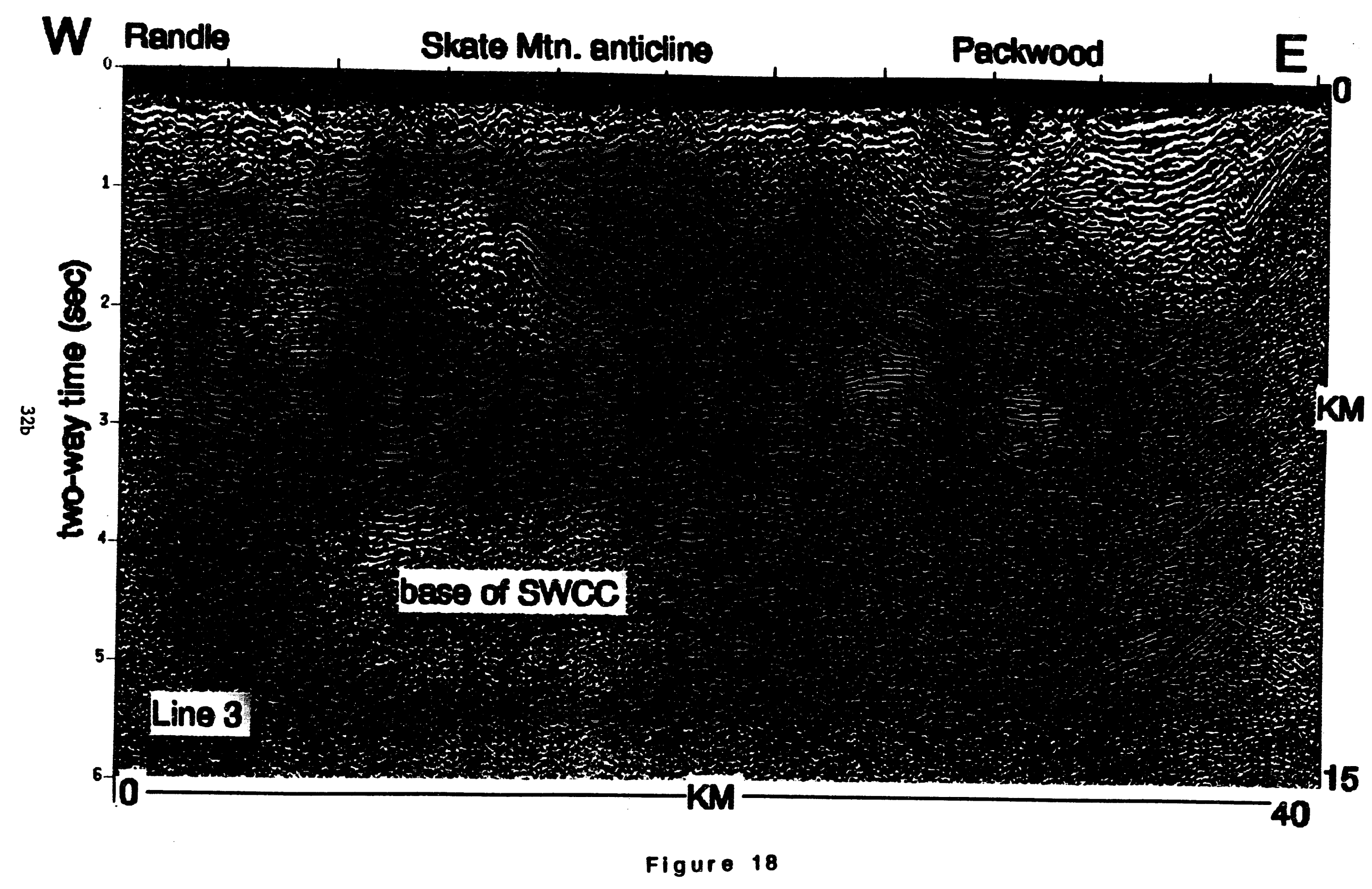


by projecting the folded reflectors to the west back toward these two events, we have now assigned the reflector at 4 seconds to pre-Tertiary basement. Details of the reflection data in this area are shown in Figure 19 from Stanley and others (1992), but we now interpret the basement as occurring at the reflection starting at the letter " $/$ "

Figure 19-Expanded plot of the east end of DOE Iine 3 from stanley and others (1992).

in "MULTIPLES" (at 3.2 seconds). With velocities chosen from the synthetic curve of Figure 14, the section from 1.9 seconds to 4 seconds would have an average velocity of about 15,000 feet/sec. The pre-Tertiary basement below the basin near Packwood is at about $10 \mathrm{~km}$ depth using the postulated velocities for the volcanic and sedimentary rocks.

There is an abrupt transition from the eastern folded reflectors under the Packwood area to nearly horizontal reflectors west of the Skate Mtn. anticline/antiform. From the seismic data, it is clear that the "anticline" is truly an antiform that is in actuality the upthrust flank of the synform to the east. The defining thrust is clearly imaged just below the word "Skate" on the section. Detail of the data near the thrust fault is shown in Figure 20. In a later section, we will show that this thrust has currently been reactivated as part of a strike-slip zone defined by

Figure 20-Expanded plot of DOE line 3 data for skate ktn. antiform.

earthquakes recorded since 1980. Hypothesized marine sedimentary rocks and hightemperature zones associated with the SWCC occupy the portion of the seismic section from 2 to 4 seconds on the west and about 3-6 seconds on the east, with a pronounced uplift in the MT model (Fig. 11) for profile $A^{\prime}$ near the Skate Mtn. antiform. A bright, cross-cutting series of reflections just west of the word "Packwood" at 2-2.6 seconds travel time may be related to side-swipe, or out-of-plane reflections, caused by major plutons that occur north and south of the seismic profile. We are currently modeling this geometry with SU (Stockwell, 1993) to study the effect.

Krehbiel (1993a) suggested that the reflectors on the east end of DOE line 3 might be connected, past the Cascades, to Eocene sediments tested under the Columbia Plateau in deep wells there. He also stated that "Since the correlation is interrupted primarily by the Miocene-aged Cascades, this correlation seems plausible." Although the case might be made for some nonmarine units such as those at Summit Creek (Stanley and others, 1992; Vance and others, 1987) extending further to the east, it is not likely that any of the marine units do so. The nonmarine sediments 


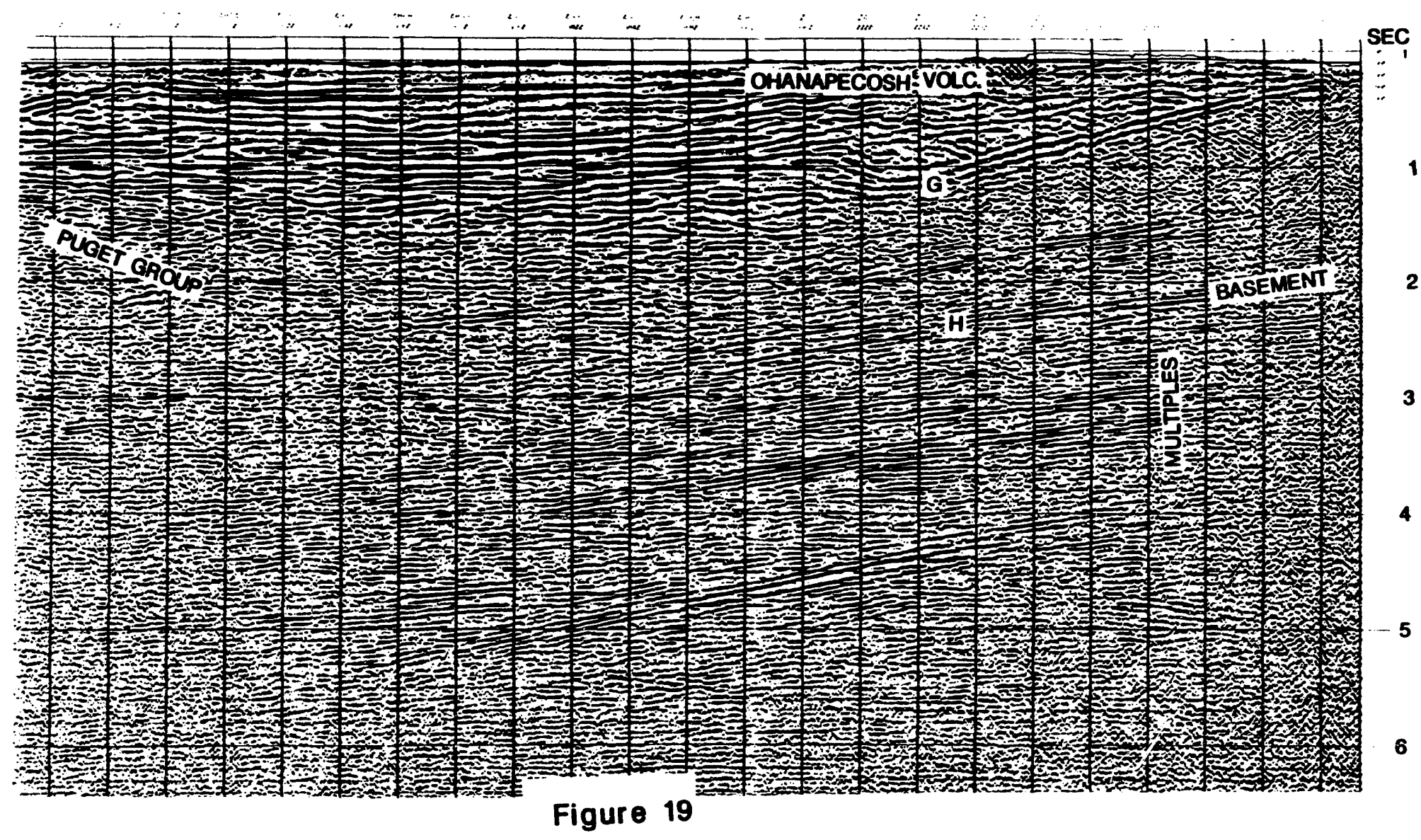




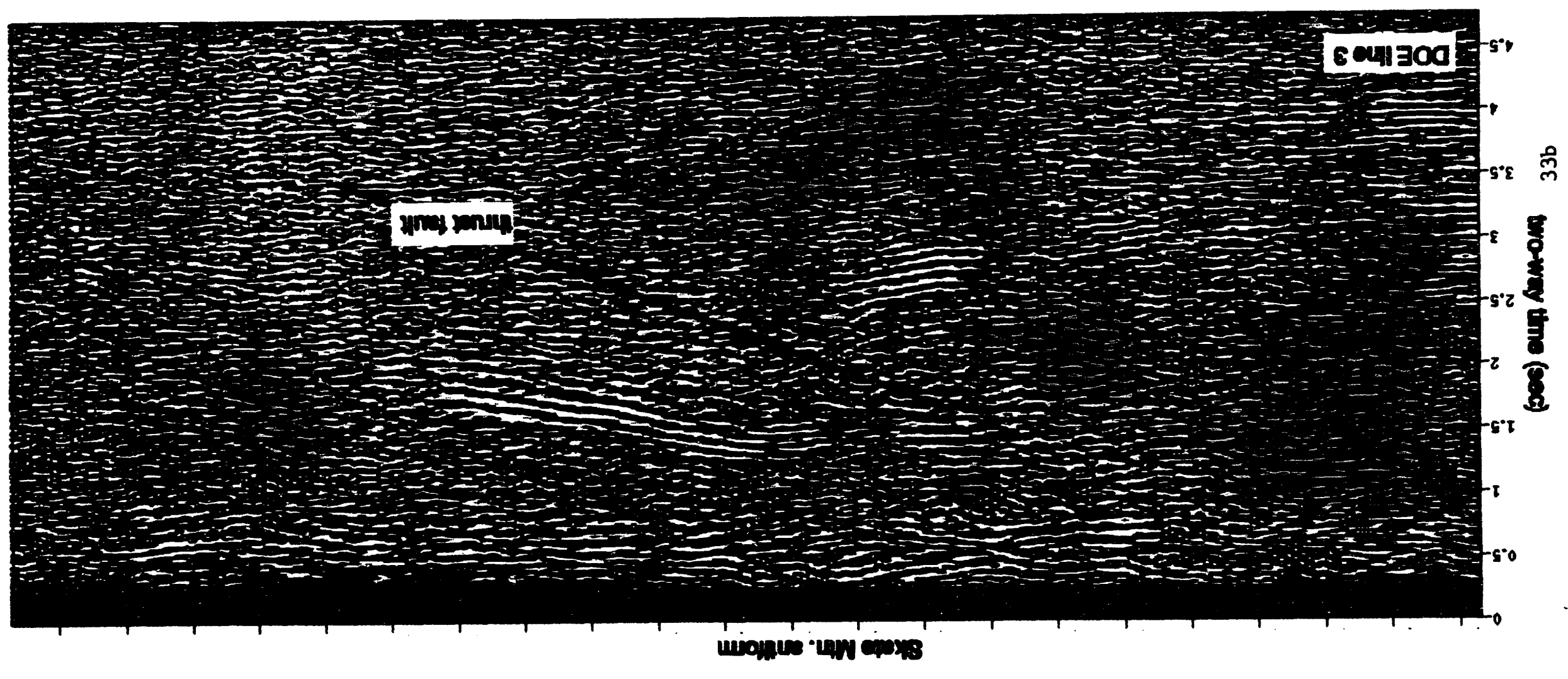


beneath basalts in the Columbia Plateau may be partially correlated stratigraphically with Eocene nonmarine units in the Swauk and other basins in northwestern Washington, but there is no evidence in any of the deep wells drilled in the Plateau for similar age marine units. Additionally, the deep reflecting units that we correlate with conductive marine units in the eastern part of the SWCC dip downward to depths greater than $20 \mathrm{~km}$ until they disappear at the western margin of the Columbia Plateau; therefore, there it is not likely that there is any association with the Tertiary sediments in the Plateau.

Data from seismic profile 5 are shown in Figure 21. This profile (Fig. 3) crosses

Figure 21-Gray scale amplitude plot of seismic data from DOE 1 ine 5.

the Morton antiform somewhat along strike and the data are much poorer overall than on lines 1, 2, and 3. The Morton antiform upper surface is clearly imaged, as is the dipping basement sequence (see events on Figs. 16 and 17). The southwest end of line 5 actually coincides with line 1 and the appearance of the sections is the same. The Morton antiform appears to plunge to the north, as suggested by rather poor evidence in the reflection data. Data from line 6 are shown in Figure 22. These data were the poorest of the overall survey with contributing factors being use of an active

Figure 22-Gray scale amplitude plot of seismic data from DOE line 6 .

logging road, very crooked profile geometry (Fig. 3), and even more complicated geological structures than occurred on the other lines. There is very little worth noting on the section for line 1 other than the rather obvious crooked geometry problem on the west end of the section (which has been highlighted). This part of the data was obtained from the shotpoints sequences 50-80 in Figure 3.

In addition to the interpretations of the seismic reflection data by Stanley and others (1992) and in this report, others have used some of the data for slightly different views of the SWCC region. The earliest of these reports is that of Boswell and others (1988). These authors interpreted stratigraphy along the west end of Lauren (then StrataSearch) seismic profile A2-3 in the Chehalis Basin (Fig. 1). The main thrust of their study was development of a seismic stratigraphy based upon the reflection data and several key well along the profile. They utilized sonic logs to compute synthetic seismograms for comparison with the profile information. Their synthetic seismograms do not provide a great deal of confidence about using synthetic seismograms for stratigraphic picks in the Chehalis Basin over long distances, and such data could not be usad for stratigraphic analysis in the SWCC region because of 


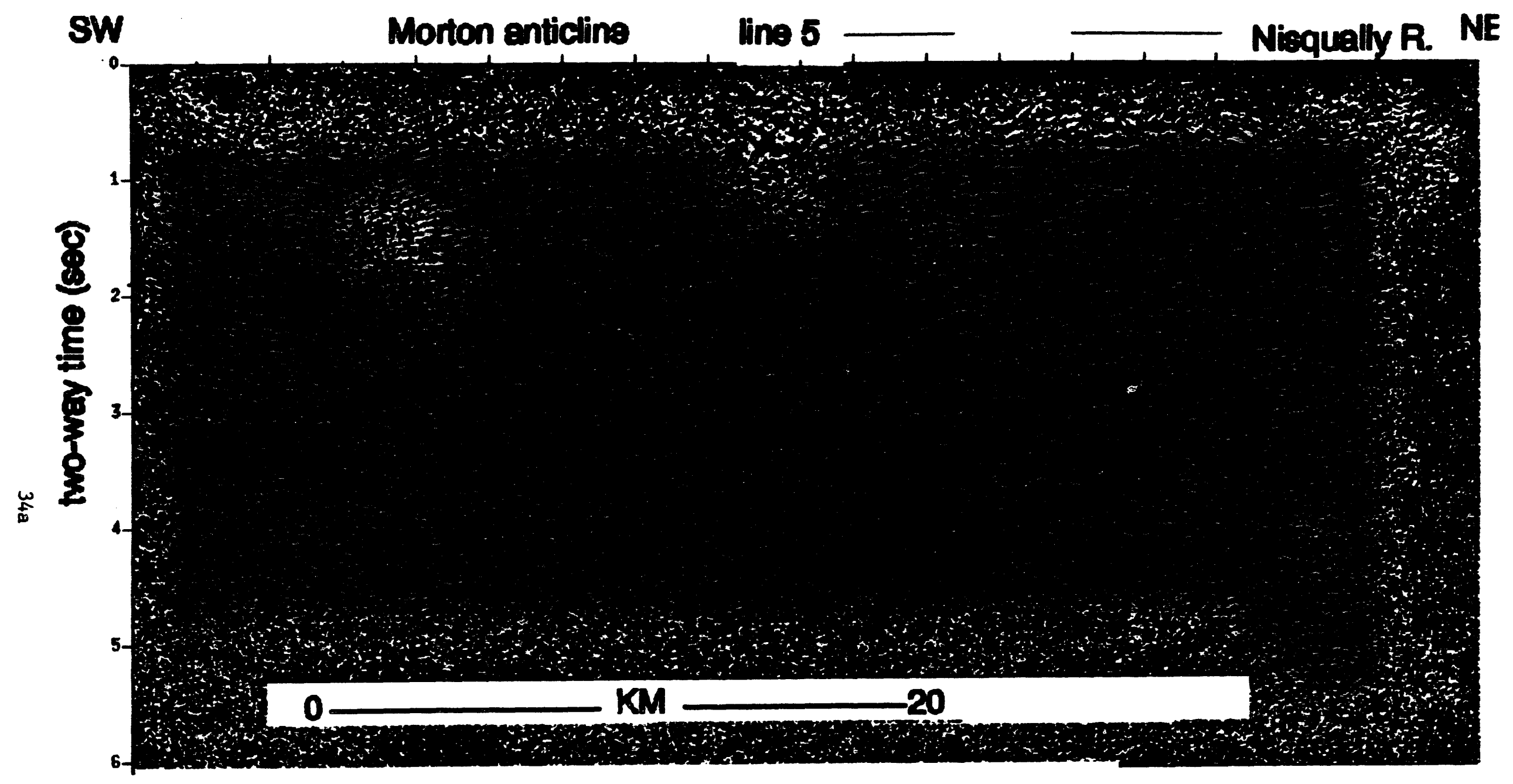

Figure 21 


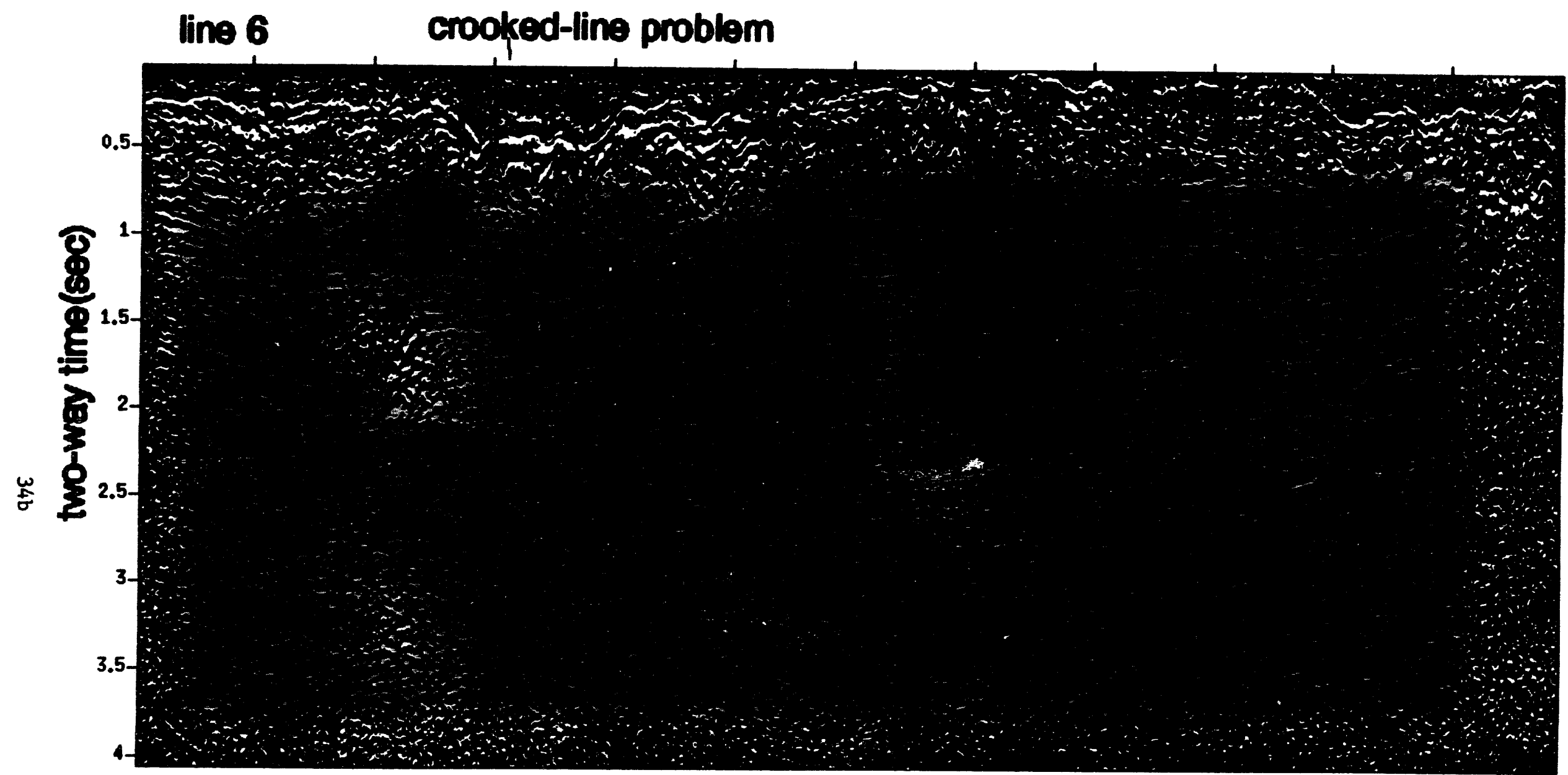

Figure 22 
the lack of wells. Their main contribution involved defining depositional facies from downlap, onlap, and clinoform packages of reflectors. From these determinations they concluded that the data fit well the third-order sea-level curve of Vail and others (1987) for the Eocene-Oligocene time period, but recognize that there is disagreement by Armentrout and Suek (1987). Stratigraphic interpretation of StrataSearch data from the Chehalis Basin and DOE lines 1, 2, and 3 by Krehbeil (1993b) contained serious problems in the Chehalis Basin, as noted above. Krehbeil (1993a) interpreted the seismic data for Line 3 to indicate a large, vertical pluton in the area where we have indicated a reactivated thrust (Figs. 17,18), but the reflection horizons are continuous within the area he outlined as an intrusion, making his interpretation implausible.

\section{SEISMICITY AND STRIKE-SLIP FAULTS}

It was recognized in Stanley (1984) and Stanley and others (1987) that the structures related to the SWCC had a direct bearing on the seismicity patterns in southwestern Washington. The prominent SHZ belt of strike-slip seismicity (Fig. 23) was noted to occur on the western margin of the SWCC, along a crustal boundary discussed above between Siletzia basement and the overlying Chehalis Basin with possible pre-Tertiary basement and intervening Eocene and older marine sedimentary rocks. This boundary and the eastern boundary of the SWCC, possibly at the preTertiary continental margin, appear to localize both earthquakes and the location of the three regional stratovolcanoes (Fig. 23). Further details of the seismicity can be noted in Figure 23, on which we have drawn lines where linear belts of seismicity and focal mechanism suggest strike slip faults. Besides the SHZ, another belt of linear seismicity occurs coincident with the Carbon River and Skate Mtn. antiforms west of Mt. Rainier and is known as the western Rainier seismic zone (WRSZ). Both these zones have mainly right-lateral strike-slip motion. Another, less distinct zone connects the northern part of the SHZ with the WRSZ, and contains left-lateral events. Another, minor zone of left-lateral slip occurs in the upper part of the Cowlitz River Valley and is thought to be related to the Cowlitz River fault noted by Don Swanson, USGS, discussed above. The strike-slip pattern is reminiscent of sets of anastomosing strike-slip faults in a transpressive environment typical of parts of the San Andreas fault system in southern California (Nicholsen and others, 1986). The left-lateral

Figure 23-seismicity in the swCC and puget sound region with interpreted stike slip faults and location of WT and seismic profiles across the Carbon River antiform.

motion in a predominantly dextral, oblique stress environments is explained by Nicholsen as the result of interior block distortion and rotation within a transpressive regime. 


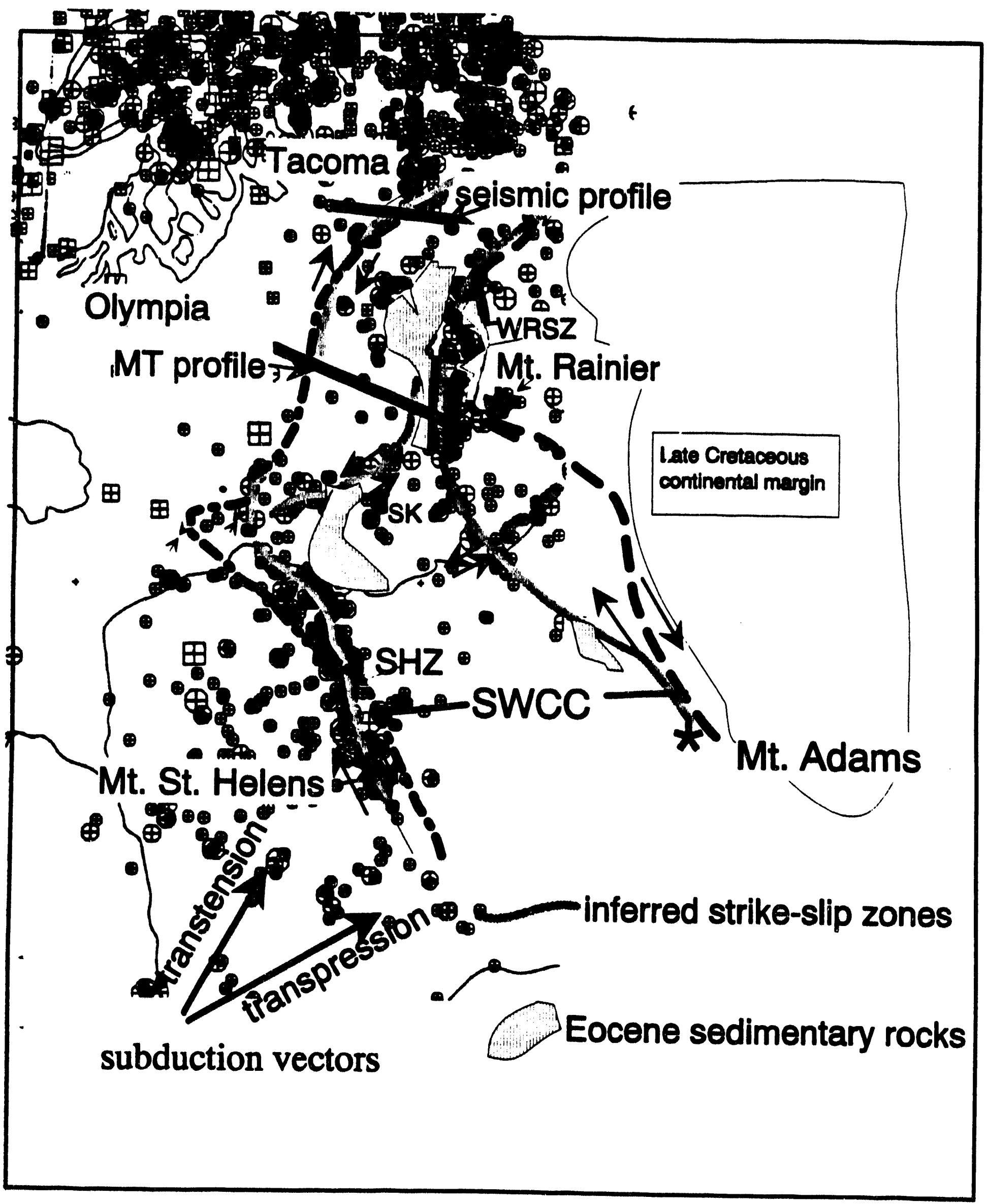

Figure 23 
As part of regional earthquake hazards studies, a detailed MT profile was completed across the WRSZ (see Fig. 23 for location). A 2D inversion of the data from

Figure 24-NT profile model across the Carbon River anticline.

this profile is shown in Figure 24, with the SWCC conductive units shown interrupted by an interpreted pluton of probable Oligocene/Miocene age. Earthquakes occur at depths of $5.15 \mathrm{~km}$ in the WRSZ, mostly within the SWCC and generally are probably related to reactivated internal thrusts, as we will discuss below, but a cluster of earthquakes was found to be directly related to the boundaries of the pluton.

Figure 25 shows a segment of an industry seismic line (courtesy of $L$. B. Industries, Denver) that crosses the trace (approximate location in Fig. 23) of the Carbon River antiform where it plunges north below Quaternary deposits (tinted part of seismic data) of the Puget Lowland. The seismic data reveal a complex zone of

\section{Figure 25-selsmic data section from the Carbon River anticline}

reverse and thrust faults, consistent with the inferred transpressional origin of the antiform (Johnson and others, 1994).

To further use seismic events to study the SWCC region, we plotted seismicity along the transect formed by seismic lines 4, 1, 2, and 3 lapproximately along U.S. Highway 12). The east-west transect for the seismicity plot was 0.25 degrees wide and centered at $\mathbf{4 6 . 5 5}$ degrees north latitude (Fig. 3), representing data in the University of Washington catalog from 1977-1992. All events deeper than $2 \mathrm{~km}$ and with magnitudes greater than 1.5 were used and are plotted in Figure 26 on a simple geological cross-section constructed from the MT and seismic reflection interpretations. On the west end of the profile a deep cluster of events forms the expression of the NNW trending SHZ of Figure 23. However, in this cross-section, there appears to be a west-dipping zone of events that connects the deep cluster to the core of the Morton antiform. We interpret this zone as related to the thrusted lower surface of the Crescent Formation basement block discussed above in relation

Figure 26-Seismicity cross-section along DOE lines 1,2 , and 3 with geological section background. Seismic events for a north-south span of 0.25 degrees were projected onto the east-west profile.

to Figure 8 (seismic line 4). We infer that there may be a vertical strike-slip fault that 


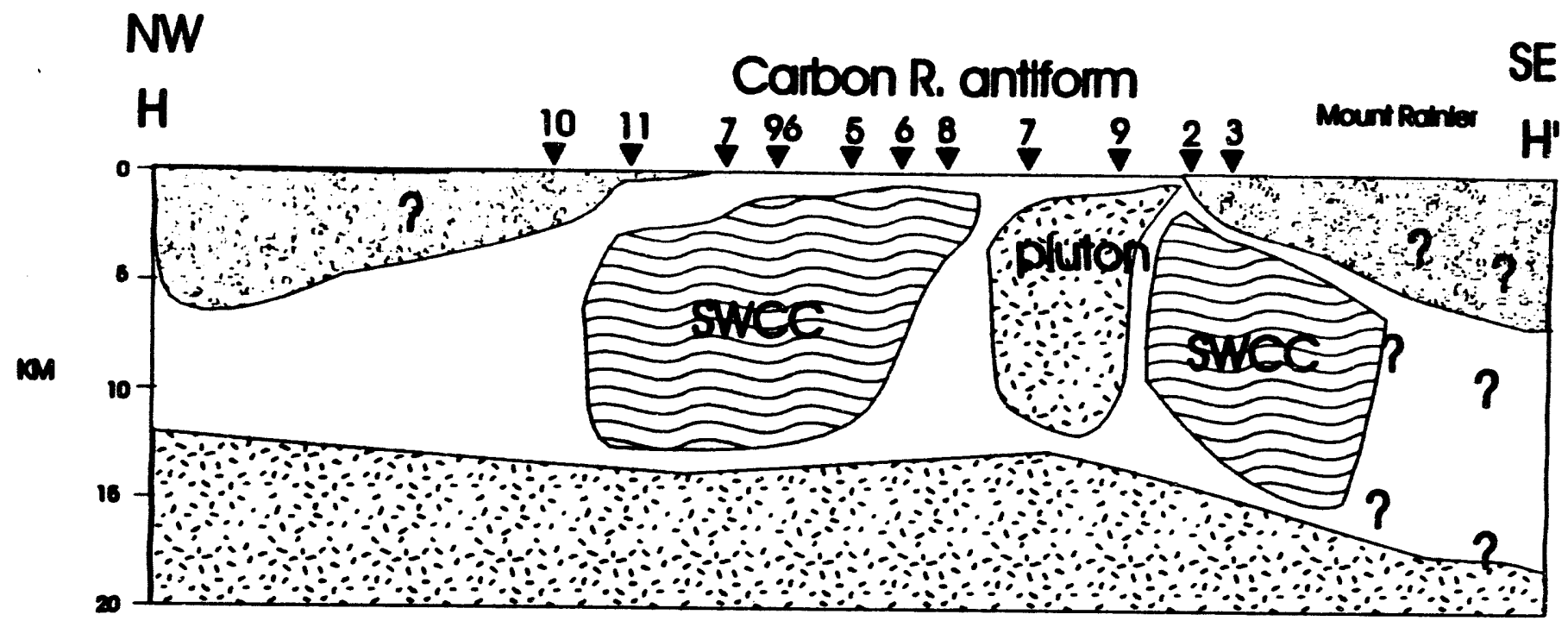

\begin{tabular}{llllll}
0 & 5 & 10 & 15 & 20 & 25 \\
\hline
\end{tabular}

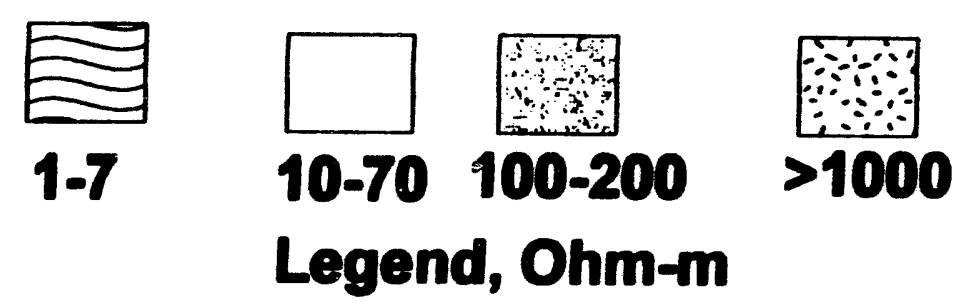

Figure 24 


\section{Carbon R. antiform}

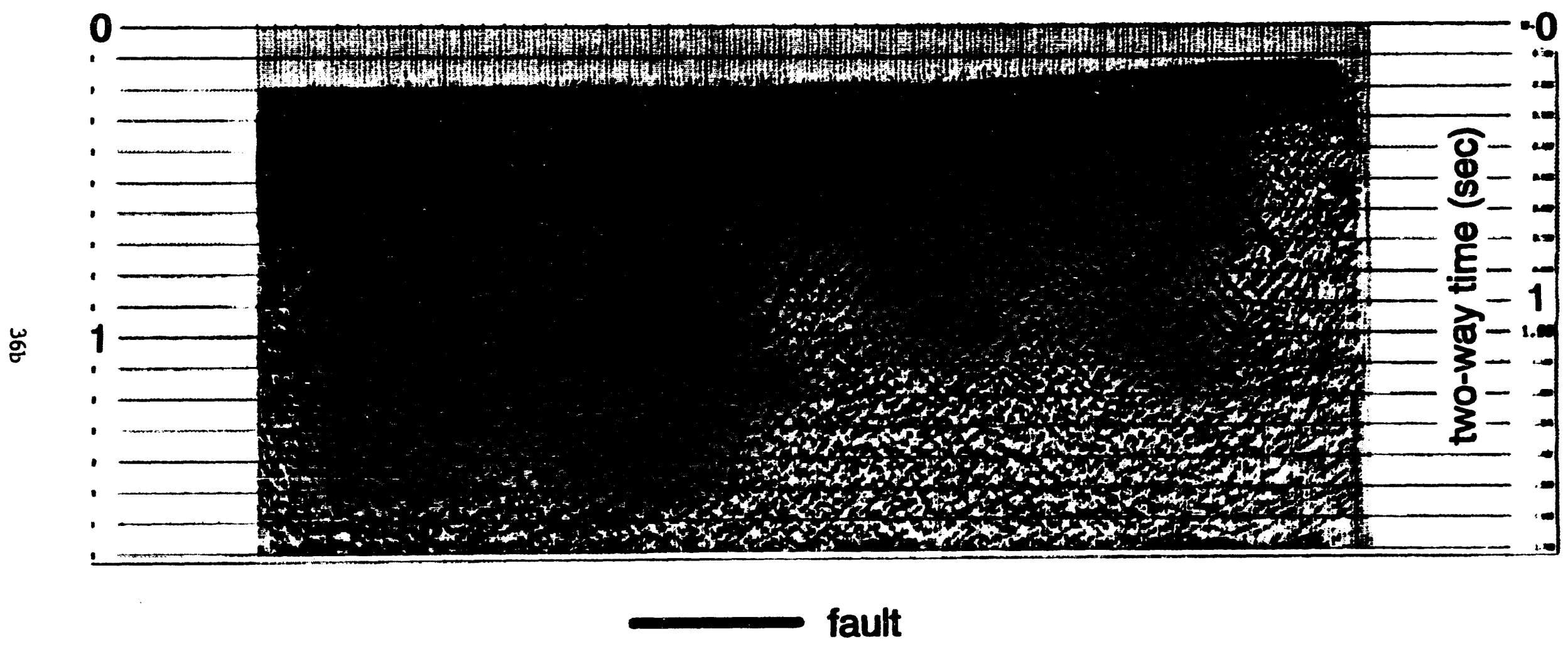

Figure 25 


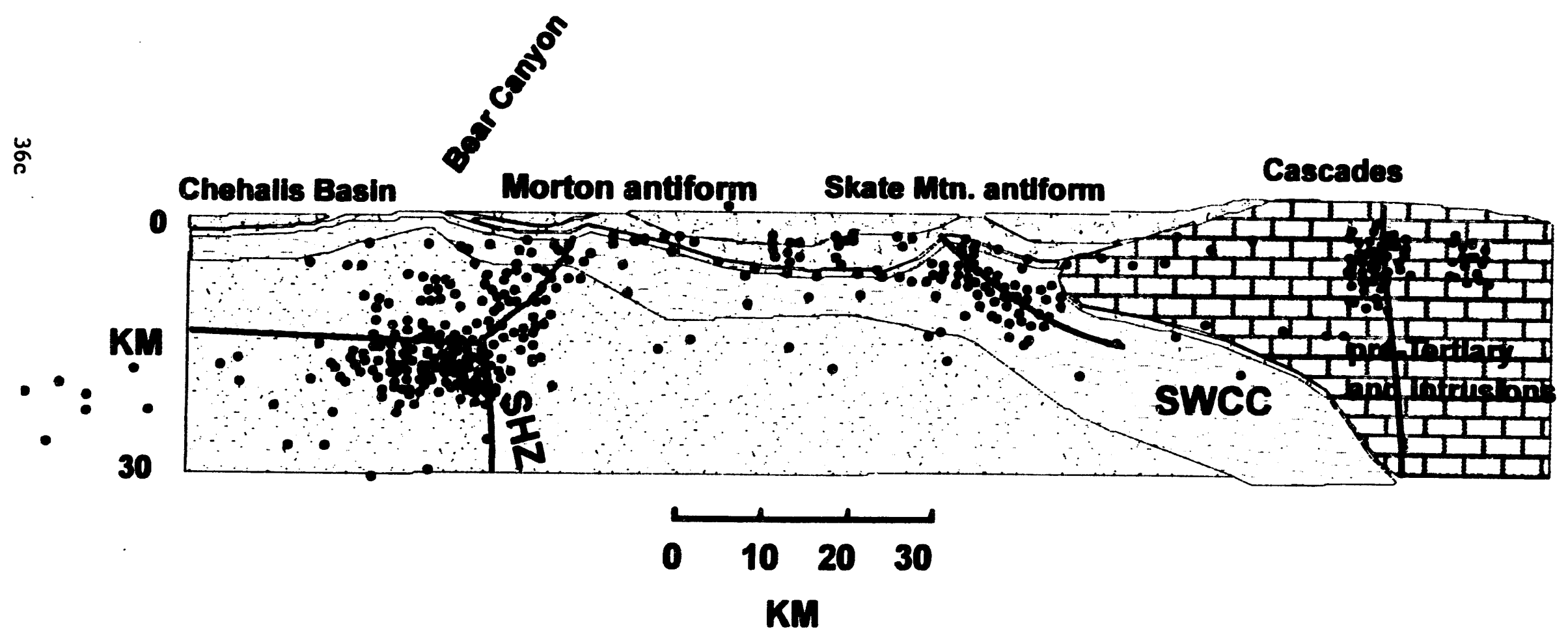

Figure 26 
couples the upper-crustal part of the $\mathrm{SHZ}$ to the underlying plate; however, there are no details in the seismicity to confirm this and other configurations of the deep part of the SHZ are possible.

An east-dipping zone of seismicity is indicated in the core of the Skate Mtn. antiform and we interpret that this zone is related to the thrust fault interpreted on seismic line 3 (Figs. 18,19). The thrust probably formed in Late Oligocene to Miocene compression and has been reactivated under current right-lateral slip. Along the eastern margin of the Cascades a belt of seismicity occurs along a bounding strike-slip zone that is best expressed near the Goat Rocks volcano area southeast of Packwood, WA. 


\section{TECTONIC MODELS: SUBDUCTION AND/OR PULL-APART?}

A summary tectonic model using the latest stratigraphic, MT, seismic reflection, seismicity, gravity, and magnetic information is shown in Figure 27. Development of the Chehalis Basin was apparently by downwarping rather than uplift of the surrounding region, as indicated by the low thermal maturity of the sedimentary rocks in the basin. The basement of the Chehalis Basin is composed of the Crescent

Figure 27-Final interpretive geological section across the Chehalis Basin and swce.

Formation flows and possible underlying oceanic crust, and has been uplifted through a series of normal faults to a shallow position near Bear Canyon. Significant strike-slip faults in this area make it impossible to complete accurate stratigraphic correlations from the Chehalis Basin into the Morton antiform area, but regional studies of sedimentary rocks suggest that the conductive rocks at depth in the antiform are probably like those of the Mclntosh and Raging River Formations. They are overlain with thick, largely nonmarine sedimentary rocks of the Carbonado and equivalent formations. Oligocene/Miocene volcanic rocks of the Stevens Ridge Formation are in contact with Eocene volcanic of the Northcraft Formation due to the basement uplift west of Bear Canyon. Gravity and magnetic data suggest that portions of Crescent basement occur east of the Bear Canyon area. In addition, the clearly banded, continuous dipping reflections beneath the Morton antiform (Figs. 17,18) suggest a possible interlayered volcanic/sedimentary sequence or other type of layered basement rocks below the interpreted thick marine sedimentary section. Although it possible that these reflectors are associated with the Crescent Formation, other geologic units are also compatible with the reflection data. Regardless it is highly likely that at some point east of the axis of the Morton antiform, pre-Tertiary basement of allochthonous origin probably underlies the SWCC. A very thick volcanic basin developed during deposition of the Ohanapecosh volcanic flows, possibly enhanced by east-west compression that finally caused a major thrust fault in the core of the present Skate Mtn. antiform.

Most of the conductive section under the Morton antiform is probably clearly related to deposition in a pull-apart basin similar to others in Western Washington, but with probable marine deposition (see detailed discussion below on Morton antiform lithology). However, the mapped thrusting of the conductive rocks beneath the preTertiary basement on the eastern margin of the SWCC indicates that the depositional model of a pull-apart basin for the overall conductive section may be overly simplistic. We suggest again, as in Stanley and others (1992) that the deeper parts of the section in the eastern half of the aromalous region may be related to an accretionary complex 


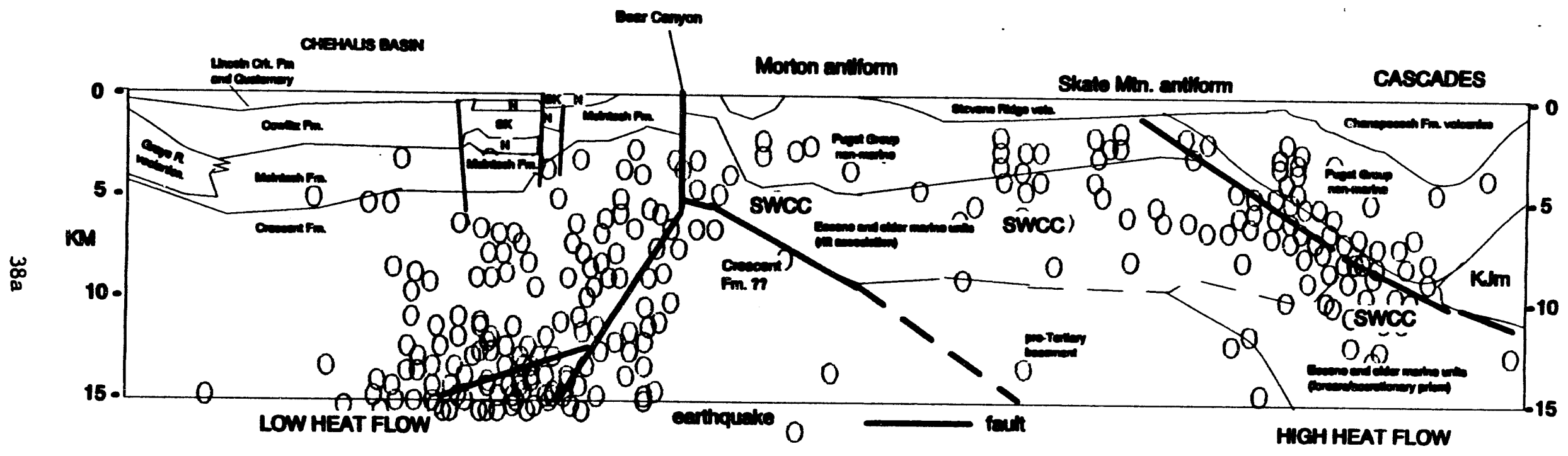

Figure 27 
not exposed at the surface or in wells in this locality. Nevertheless, along the continental margin of British Columbia, including Vancouver Island, both Cretaceous forearc and post-subduction (after suturing) sediments, as well as marine and nonmarine rift sediments are found in the Queen Charlotte and Georgia basins (Yorath, 1987). The Cretaceous marine sedimentary units are part of a subduction-related and post-suture sedimentary sequence that extends from central California to Alaska, and probably also occurred in western Washington.

Up to $5 \mathrm{~km}$ of a Neogene rift assemblage, both marine and nonmarine, occurs in the Queen Charlotte Basin on top of unknown thicknesses of upper Cretaceous, post-suture marine and nonmarine sedimentary rocks (Yorath, 1987). The basin basement is formed by lower Cretaceous subduction units that have been thrust over Wrangellia (an accreted terrane that extends from Vancouver Island to southcentral Alaska; Jones and others, 1977). In the southern Georgia Basin, along the east side of Vancouver Island, about $3 \mathrm{~km}$ of upper Cretaceous to Paleocene, Nanaimo Group marine and nonmarine sedimentary rocks are overlain by $3 \mathrm{~km}$ of nonmarine Eocene Chuckanut sedimentary units (P. D. Hurst, oral comm., 1993). Eisbacher (1985) interprets the Nanaimo Basin (southern part of Georgia Basin) as part of a forearc system dominated by strike-slip, and that coeval, distal trench deposits were removed by dextral slip or subducted beneath the continental margin. We envision that the mix of trench and marine/nonmarine pull-apart sedimentary units found in the Queen Charlotte and Georgia Basins may also occur in the SWCC, with the largest volume being marine.

We suggest that the SWCC first developed as portrayed in Figure 28 during oblique subduction of the Kula plate beneath North America as part of a typical accretionary prism and forearc basin. By Paleocene; the dextral-slip component of

Figure 28-paleotectonic development of the swcc region from stanley and others (1992).

oblique subduction probably led to a pull-apart environment for the forearc region. The formation of pull-apart structures in the forearc region led to thick marine, rift sediments being deposited upon late Cretaceous-Paleocene accretionary sediments. This transtensional environment may have interacted in a complex manner with a local, small spreading center to cause a thick build-up of oceanic basalts and seamounts (Siletzia), forming a rew forearc basement. Allochthonous terrane slices of pre-Tertiary rocks may also have been transported northward into contact with the rift/accretionary assemblage; remaining forearc sediments of late Cretaceous age migrated northward along with other margin components to the present Vancouver Island region. Local volcanic centers erupted the Eocene Tukwila and Northcraft Formations. An accretionary prism/forearc basin system formed outboard of the Siletzia complex; thereafter, thick volcanic flows of the Ohanapecosh Formation 


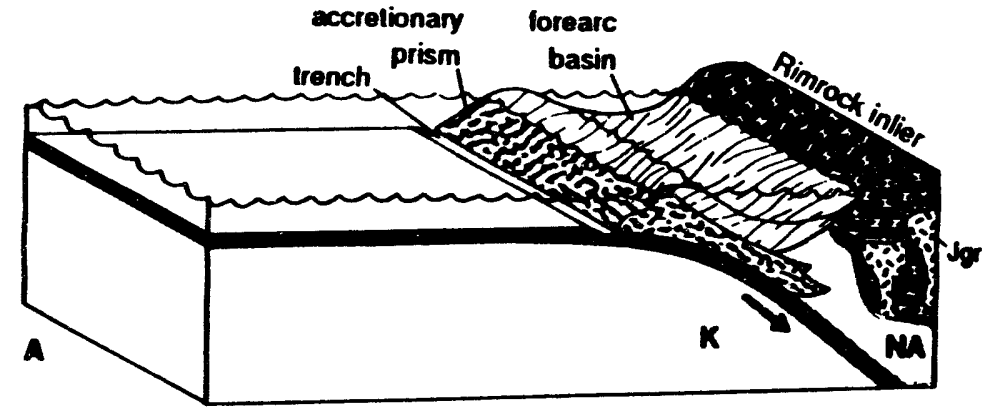

LATE CRETACEOUS - PALEOCENE

$\underset{\infty}{\omega}$

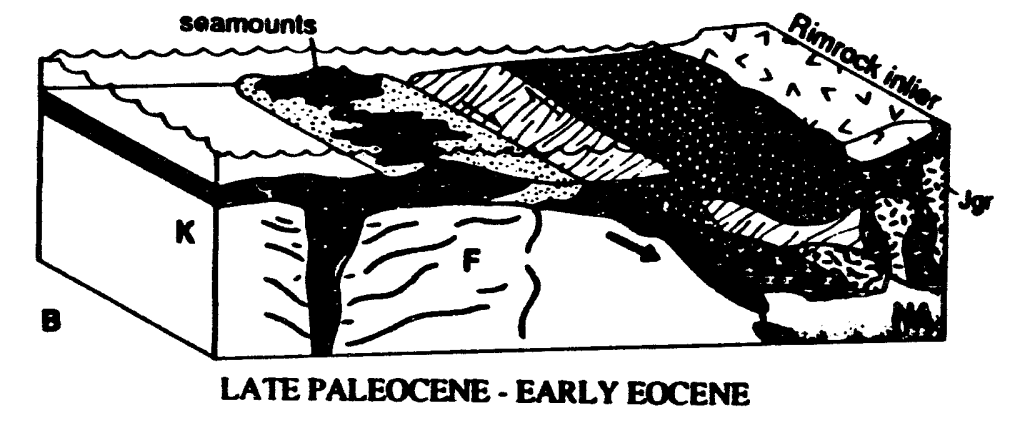

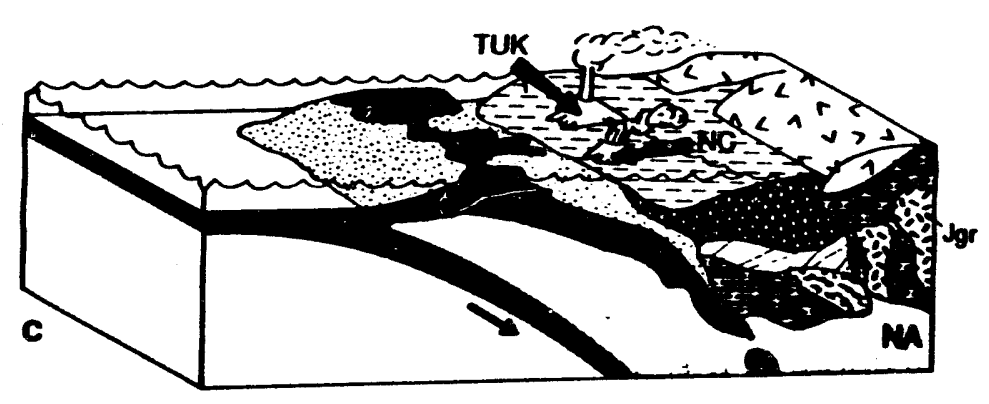

EARLY TO MIDDLE EOCENE

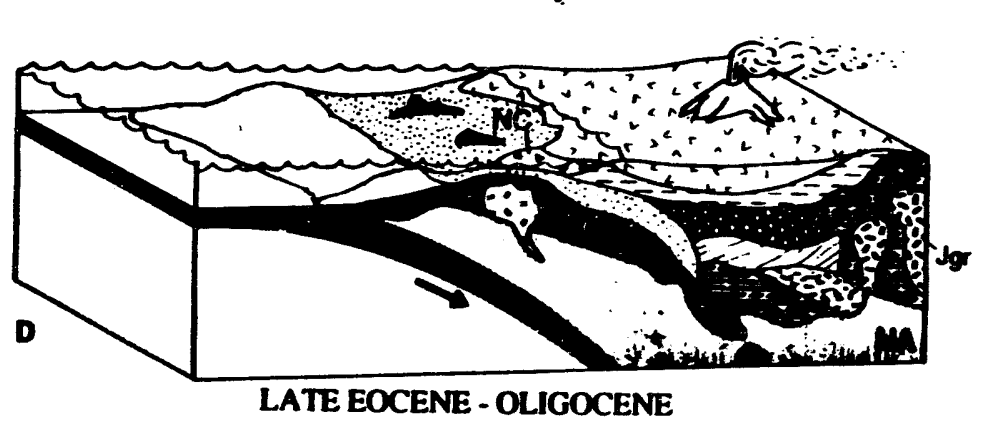

EXPLANATION

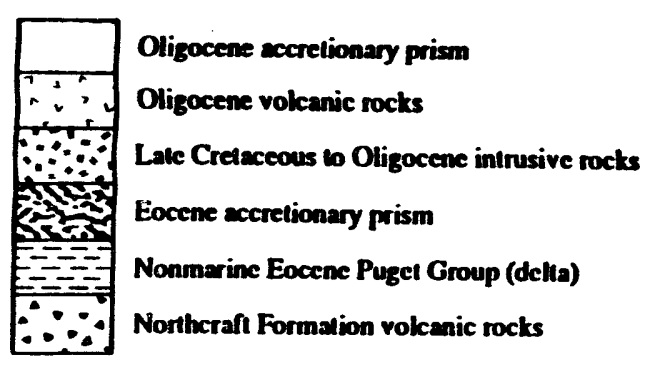

Marine pull-apart sedimentary rects
and proximal sediunentary rocks
Late Paleocene - carly Eocene volcanic rocks
Late Cretaceous - Palcocene forearc basin
and accretionary prisan
Rimrock inlier and other accreted terranes
(Jgr = Juressic intrusive rocks)

-Our interpretation of tectonic development of westem Washington from late Cretaceous to Oligocene adapled from Armentrout and Suek (1985), Ise (1985), Snavely (1987), Eisbacher (1987), and Johnson (1987). See text for explanation.

\section{Figure 28}


signaled the establishment of the Cascades volcanic arc associated with the new subduction zone.

This concludes our discussion on the regional tectonics of the SWCC region, and we turn in the next section to a detailed analysis of the most obvious hydrocarbon exploration target in the area, the Morton antiform. 


\section{MORTON ANTIFORM STRATIGRAPHY AND SEDIMENTOLOGY}

Five stratigraphic sections through portions of the upper part of the Carbonado Formation were measured in the Morton antiform llocations in Figs. 4,29 and Appendix A) ranging in thickness from approximately $110 \mathrm{~m}$ to $500 \mathrm{~m}$. Figure 28 is used as an index only, since our geological mapping (Fig. 4) has revised some of the contacts represented on the original map of Walsh and other (1987). A 33-m-thick section was also measured from outcrops at Bear Canyon. Appendix $A$ includes 1) maps showing exact locations of the measured sections; 2) plots of the measured sections; and 3) raw vitrinite reflectance data collected for samples from within the sections. Rocks in these sections consist of interbedded intervals of mainly nonmarine rocks and mainly shallow to marginal marine rocks. Volcaniclastic and volcanic rocks form significant parts of two sections. Rocks are referred to as the Carbonado Formation (Fig. 5), following the stratigraphic usage of Willis (1898) and Gard (1968) for rocks of similar age and facies exposed along strike to the north in the Carbon

Figure 29-Details of the Morton antiform region geology and location of measured stratigraphic sections. Section paths are shown on detailed topographic maps in Appendix A.

River antiform.

\section{Lithology and sedimentology}

Lithology and sedimentology of strata exposed in the Morton antiform and cored in the AMOCO 83-5 borehole are briefly discussed below and will be described in detail in future publications. These strata consist of mainly of siliciclastic and less common volcaniclastic rocks deposited in nonmarine to shallow- or marginal-marine environments.

\section{Nonmarine deposits}

Nonmarine intervals within the section dominate, comprising about 67 percent of the measured sections. Strata are of inferred fluvial channel and overbank origin. Fluvial channel deposits consist of trough crossbedded, low-angle to horizontal bedded, ripple-laminated, and structureless, very light gray to very pale orange, fineto coarse-grained sandstone and rare conglomerate. Fluvial sandstone bodies are typically 5 to $20 \mathrm{~m}$ thick; the $70-\mathrm{m}$ sandstone body of inferred fluvial origin at the top of the South Fork of the Tilton River section is an anomaly. Sandstone bodies of inferred fluvial origin generally have sharp erosive bases. Upper contacts of sandstone bodies with overlying fine-grained strata are both graded and sharp. Sandstone bodies contain abundant internal low-angle scour surfaces indicating vertical aggradation was an important process in sandstone body development. Conversely, no structures suggestive of lateral accretion (e.g., thick sets of low angle crossbeds) were 


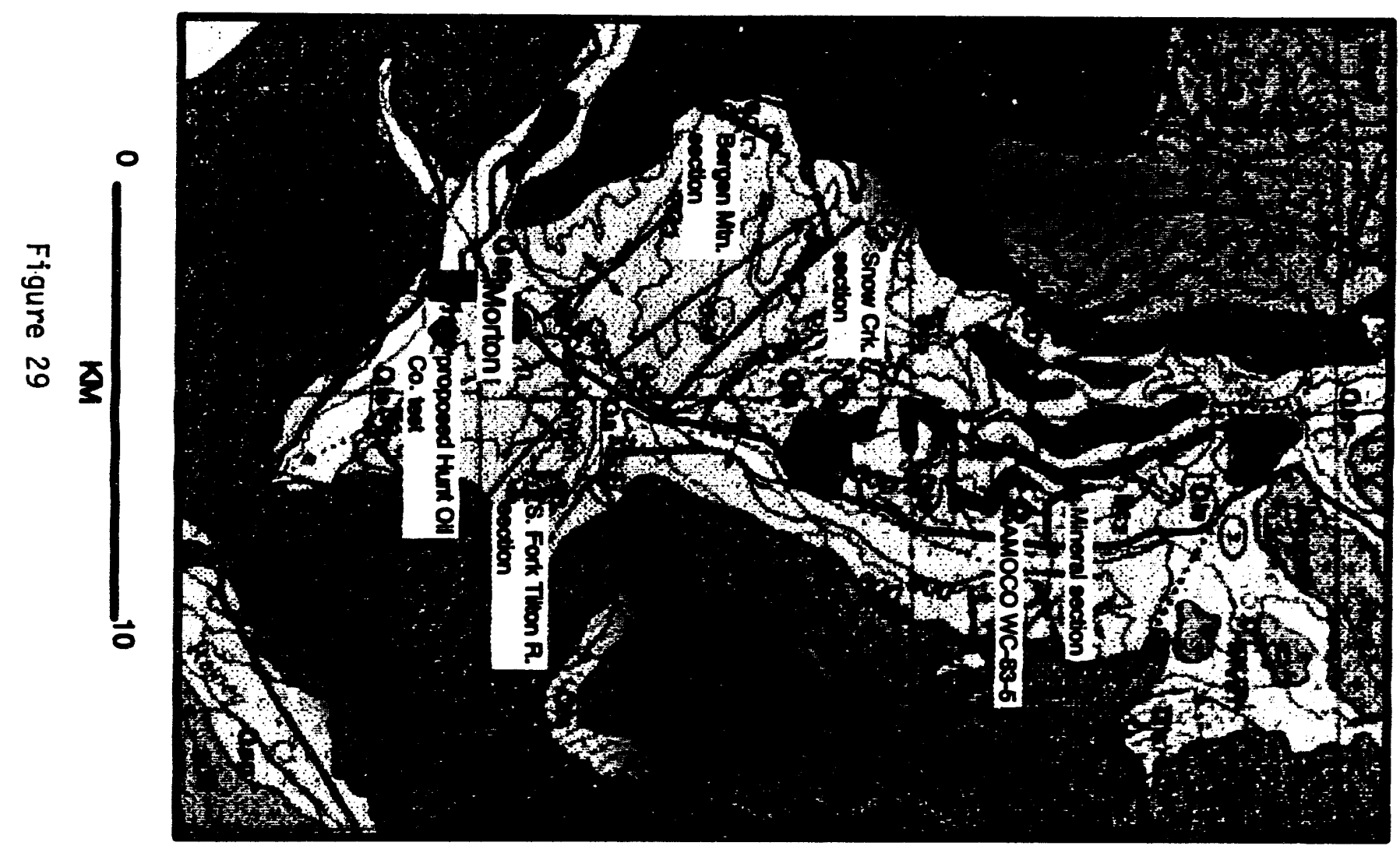


recognized. These structures may never have formed or, alternatively, the quality and scale of outcrop might preclude their recognition. Sandstone bodies could generally not be traced laterally because of limited outcrop and gentle to steep structural dips. However, one fluvial sandstone body in the Mineral section (Appendix) that could be traced laterally thinned dramatically from $14 \mathrm{~m}$ to just $5 \mathrm{~m}$ in just $100 \mathrm{~m}$, suggesting

Figure 30-Paleocurrent data for measured sections in the yorton antiform.

a ribbon geometry. Paleocurrent data (Fig. 30) indicate sediment transport was to the west $\left(X=280^{\circ}, n=113\right)$.

Three lines of evidence suggest that at least some of these fluvial sandstone bodies formed as distributary channels on a delta plain: (1) The alternating marinenonmarine character of the stratigraphic sections; (2) evidence for significant vertical aggradation within sandstone bodies; and (3) the apparent ribbon geometry of at least some sandstone bodies. Both (2) and (3) suggest channels occupied the relatively straight courses typical of distributary channels.

Strata interpreted as nonmarine overbank deposits (includes levee, floodplain, shallow lake, floodplain channel, crevasse splay, and peat swamp environments) consist of mudstone to fine-grained sandstone, and less common carbonaceous shale and coal. Parallel and (or) ripple lamination are common, however in many cases primary sedimentary structure has been partly or wholly destroyed by burrows, root traces, and pedogenesis. Fossil plant material (wood and leaf fragments) is common in these beds. Within thick fine-grained intervals, (1) uncommon lenticular beds of ripple-laminated, horizontal bedded, and trough crossbedded very fine to fine grained sandstone (generally less than $1 \mathrm{~m}$ thick) are inferred floodplain channel deposits; and (2) sheet-like beds of ripple-laminated and horizontal bedded very fine grained to fine grained sandstone (generally less than $50 \mathrm{~cm}$ thick) are inferred crevasse splay deposits. Beds of carbonaceous shale and coal (representing peat swamp deposition) range in thickness from a few $\mathrm{cm}$ to about $3 \mathrm{~m}$.

\section{Marginal- to shollow-marine deposits}

Strata of inferred marginal to shallow marine origin comprise about $33 \%$ of the measured stratigraphic sections. These rocks typically consist of parallel-, ripple-, or wavy-laminated very fine to coarse-grained sandstone, and less common parallel- to ripple-laminated mudstone with thin $(<1 \mathrm{~cm})$ sandstone laminations. Both currentand vave-ripple lamination were recognized, and many ripple sets include thin $m$ stone drapes. Primary stratification has been partly to completely destroyed in most beds by bioturbation. Burrow diameters range in scale from a few millimeters to several centimeters. The most common burrow forms are Skolithos. Ophiomorpha, Scoyenia, Asterosoma, and Teichichnus. Both shell fragments (pilecypod and gastropod) and plant fragments are common. Concentrated shell lags are rare and 


\section{Morton antiform paleocurrent data}
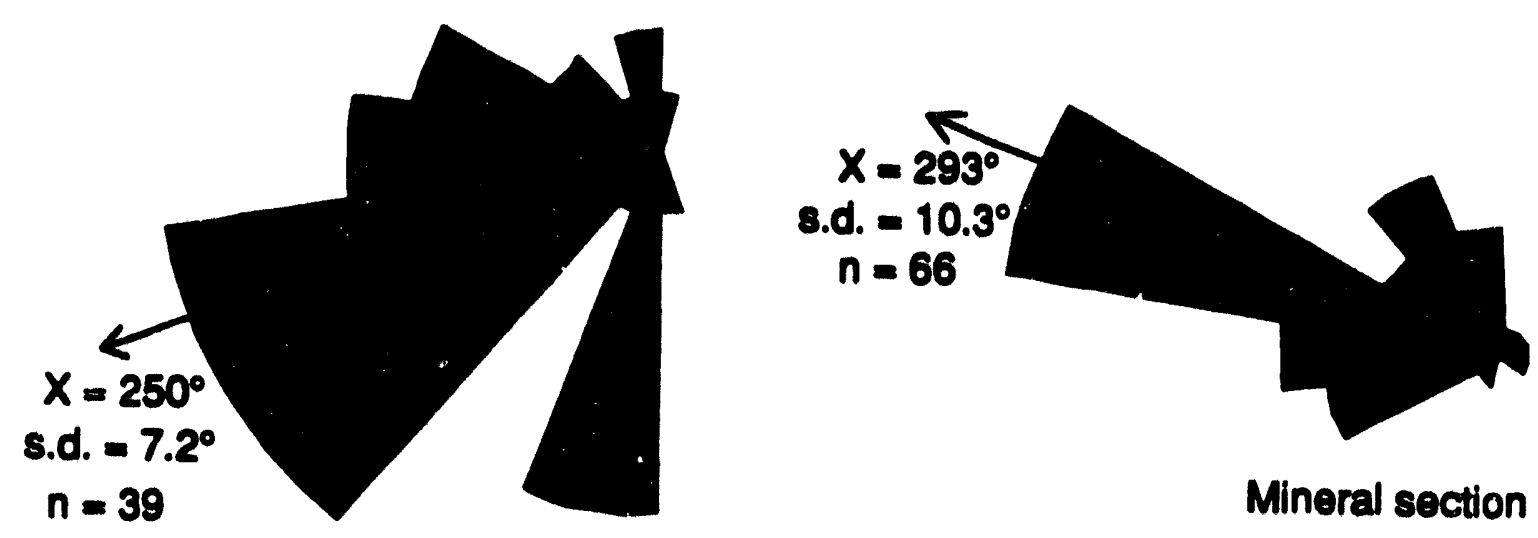

Mineral section

Bergen Mountain section
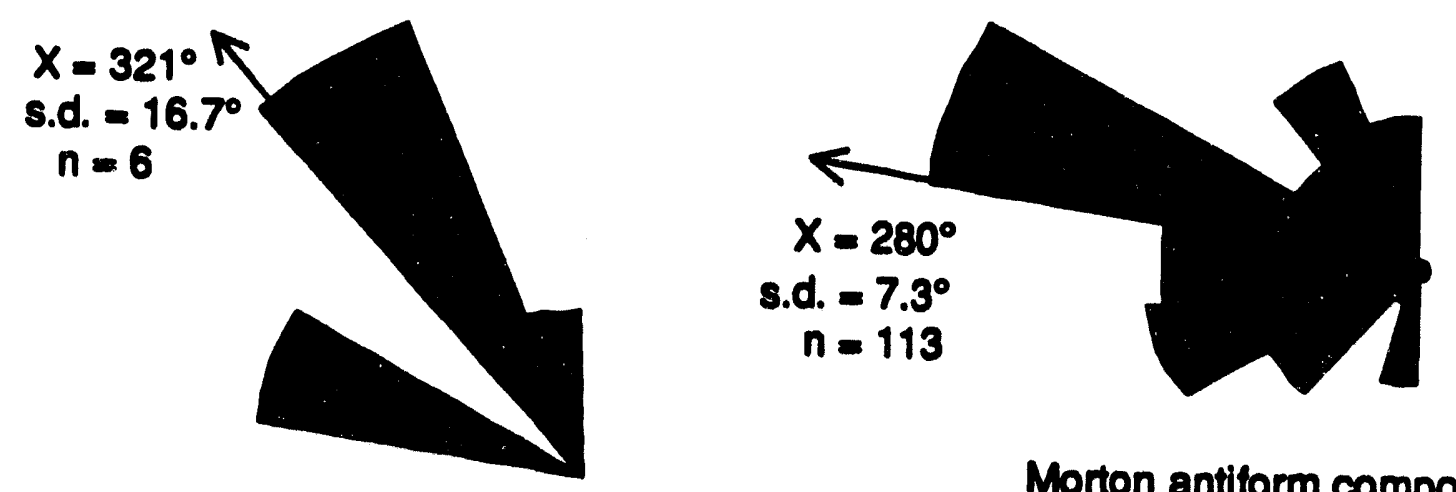

South Fork of Tilton River section

Morton antiform composite

Figure 30 
typically thin $(<15 \mathrm{~cm})$. Oval concretions occur in both mudstone and sandstone. Bioturbated sandstone beds range in color from yellowish gray to greenish gray to light bluish gray and are commonly mottled. This range of colors is distinctly different from the typical very light gray to very pale orange color of sandstone in fluvial sandstone bodies. Mudstone beds are typically medium gray to grayish black. Primary stratification, bioturbation, and fossil content indicate these sandstone and mudstone facies are marine in origin. Their alternating occurrence in sections that include thick fluvial/distributary channel sandstone bodies suggests they formed in a delta front to prodelta setting. The abundance of plant fragments suggests that these facies were not significantly reworked by waves or tides.

\section{Volcaniclastic and pyroclastic deposits}

Volcaniclastic rocks are common in the Mineral and AMOCO WC-83-5 measured sections (Appendix). Volcaniclastic strata include tuffaceous sandstone, tuff, tuffaceous conglomerate, and tuffaceous breccia-conglomerate. Volcanic sandstone is typically olive gray to olive black, in strong contrast to the much lighter color of fluvial sandstone bodies. Beds are as thick as $8 \mathrm{~m}$, generally massive, can not be traced laterally, and are commonly poorly exposed (and) or heavily weathered. Grains are fine-grained to granular, typically subrounded, and moderately sorted. Many beds have erosive lower contacts. Crude horizontal stratification and(or) grading is reflected by grain size variations in a few beds. Relatively thin $(<30 \mathrm{~cm}$ ) lenses of volcanic conglomerate are present in several volcanic sandstone beds. These conglomerate beds typically have moderately sorted, subrounded clasts, and are both clast- and matrix-supported. The texture and structure of most beds of volcaniclastic sandstone suggest they formed by redeposition of primary volcanic deposits in fluvial environments. It is possible that a few poorly exposed beds formed as pyroclastic flows.

Lithic to vitric tuff (fine tuff to lapillistone) beds are as thick as about $100 \mathrm{~cm}$ and range in color from white to greenish gray. Lighter colored beds are commonly more vitric rich, have sheet-like geometry with sharp, parallel, upper and lower contacts, suggesting origin as fallout. Darker beds are more lithic rich, commonly lenticular, and mainly formed as pyroclastic flows.

Two beds (290 to $320 \mathrm{~cm}$ thick) of valcanic breccia conglomerate are present in the Mineral section (Appendix). These beds include a mix of angular to rounded volcanic clasts (as large as $25 \mathrm{~cm}$ ) dispersed in a fine to coarse ash matrix. The presence of a thin baked zone below one of these beds suggests origin as a pyroclastic flow.

\section{Depositional model}

Carbonado Formation strata exposed in the Morton antiform and in the AMOCO WC-83-5 borehole include facies suggesting deposition in mixed nonmarine and marginal- to shallow-marine environments. The presence of thick fluvial sandstone bodies indicates these environments occupied a delta-plain to prodelta setting. Paleocurrent data indicate that drainage was to the west. The presence of 
volcaniclastic and pyroclastic strata indicate that nearby active volcanoes contributed sediment to the delta. This general model is consistent with that proposed by Buckovic (1978) for a larger area in southwest Washington. Within this type of deltaic setting, the major nonvolcanic controls on siliciclastic facies deposition are sediment supply, eustasy, and subsidence. Nonmarine deposition occurred when the combination of these factors led to a relative lowering of base level; shallow- to marginal-marine deposition occurred during relative rises of base level. At a smaller scale, autochtohnous processes (e.g., abandonment of delta lobes) can also affect marine-nonmarine patterns of deltaic deposition.

\section{Correlation of Morton antliform sections}

Reconstruction of the stratigraphy of the Carbonado Formation in the Morton antiform area is problematic for several reasons: (1) The area is densely vegetated. As a result, outcrops are sparse and mainly restricted to cuts on recently built logging roads and to exposures in stream channels; (2) The area has not been geologically mapped in detail. Existing published maps (Fisher, 1957; Schasse, 1987) are of a reconnaissance nature. (3) The Morton antiform is structurally complex, characterized by many faults and small-scale folds (e.g., Fisher, 1957; Schasse, 1987). Offsets on faults can be significant; for example, geologic relationships indicate that a fault in the alluvium-filled valley between Morton and Mineral valley (the valley of the Tilton River and Roundup Creek) has a minimum displacement of about $800 \mathrm{~m}$. Some of these structures may have been syndepositional (e.g., Johnson, 1985, Johnson and others, 1994), creating local differential subsidence and (or) uplift. (4) Marker beds within stratigraphic sequences have not been recognized, and there was no doubt complex interfingering of nonmarine, shallow- to marginal-marine, and volcanic depositional facies. There may have been more than one active volcanic center contributing volcanic detritus to the Carbonado Formation in the Morton area. (5) The location of the contact between the Carbonado and Northcraft Formation is not straightforward. For example, the contact in the area of the Mineral measured section (Appendix A) used in this report is significantly lower in the section than that mapped by Schasse (1987).

Figure 31 highlights the problem of stratigraphic correlation and the lack of marker beds. The figure shows schematic stratigraphic columns for the Mineral,

Figure 31-stratigraphic correlation section with fixed Northcraft level.

Bergen Mountain, and South Fork of the Tilton River measured sections (Appendix). All three sections are overlain by sections of mainly volcanic rocks and therefore are inferred to represent the top of the Carbonado Formation in the Morton antiform. Alignment of the sections on this contact, however, shows that the general stratigraphy for each column defined by the alternating marine and nonmarine intervals 


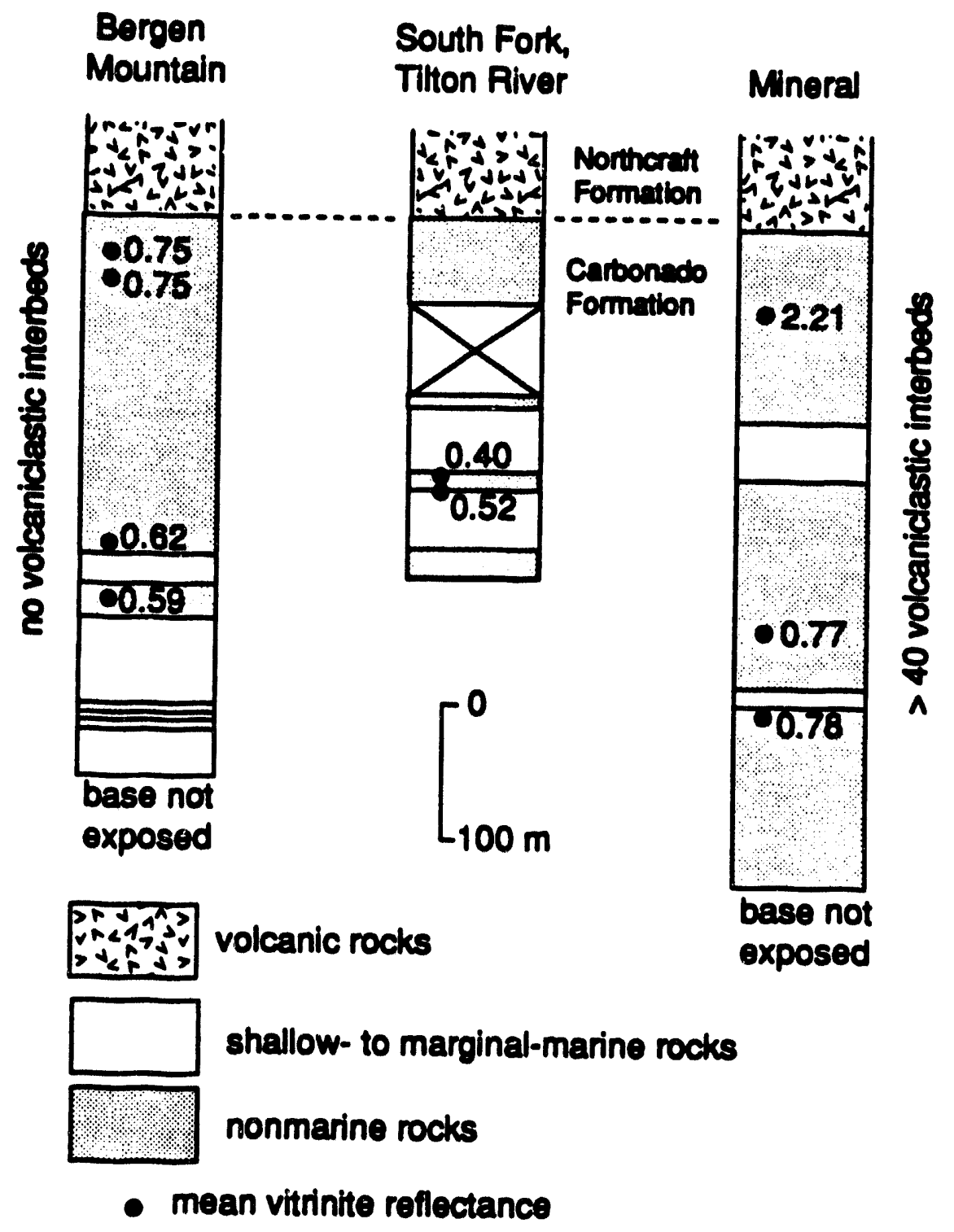

Figure 31 
cannot be matched from one column to the next. For an area as small as the Morton antiform, one would expect that the thicker marine intervals (indicative of significant transgressions) should be correlative. Moreover, the Mineral section includes more than $\mathbf{4 0}$ interbeds of volcaniclastic rocks (including many units of inferred airfall origin) while no volcaniclastics were recognized in the Bergen Mountain and South Fork of the Tilton River sections. These problems illustrate the stratigraphic complexity of the Carbonado Formation, and indicate that stratigraphic correlation in even a small

Figure 32-stratigraphic correlation section with variable Northcraft level.

structurally complex area can be difficult with a limited data base.

Figure 31 provides a more realistic correlation of the five measured stratigraphic sections, the present best guess based on rationale outlined below. The Mineral surface section and the AMOCO WC-83-5 borehole section are approximately $1 \mathrm{~km}$ apart. The local area between the two sites is structurally complex (Schasse, 1987), so simple projection of structural attitudes from one site to the other does not demonstrate absolute stratigraphic position. The Mineral section forms the top of the local Carbonado section and therefore must at least partly overlie the AMOCO WC-835 borehole section. A distinctive, thick, purplish-gray volcaniclastic unit occurs at the base of the Mineral section and was not recognized in the borehole core. Therefore, there is no duplication between the two sections; the amount of missing rock between the two sections cannot be determined based on outcrop data.

Farther south, the Bergen Ma I Intain and Snow Creek sections are about $4 \mathrm{~km}$ apart, but separated by faults Ids (Schasse, 1987). The Bergen Mountain section is overlain by volcanic f the Northcraft Formation and is therefore at least locally at the top of the Caruonado section. Map patterns (Schasse, 1987) indicate the Snow Creek section must lie well below the Bergen Mountain section, but there is insufficient data to calculate its absolute stratigraphic position.

Although both the Mineral and Bergen Mountain sections (about $12 \mathrm{~km}$ apart) are overlain by the volcanic Northcraft Formation, direct correlation of the two sections seems highly unlikely because (as discussed above) of the significant difference in the number of volcanic interbeds (Fig. 30 and Appendix A) and the lack of correlation between marine and nonmarine intervals in the two sections. Mapping by Hagen (1987) indicates that the main intrusive center for the Northcraft Formation was centered in the southwestern portion of T. 14 N., R. 3 E. (secs. 28, 29, 30, 31, $32,33)$, approximately $11 \mathrm{~km}$ from the Bergen Mountain section and $19 \mathrm{~km}$ from the Mineral section (Fig. 3). Therefore, the effects of Northcraft volcanism should have been recorded earlier in the Bergen Mountain section than the Mineral section. We infer that these effects resulted in deposition of thick Northcraft flows in the Bergen Mountain area (with only minor significant siliciclastic deposition) synchronous with continued deltaic deposition (with increasing volcanic input) to the north in the Mineral 

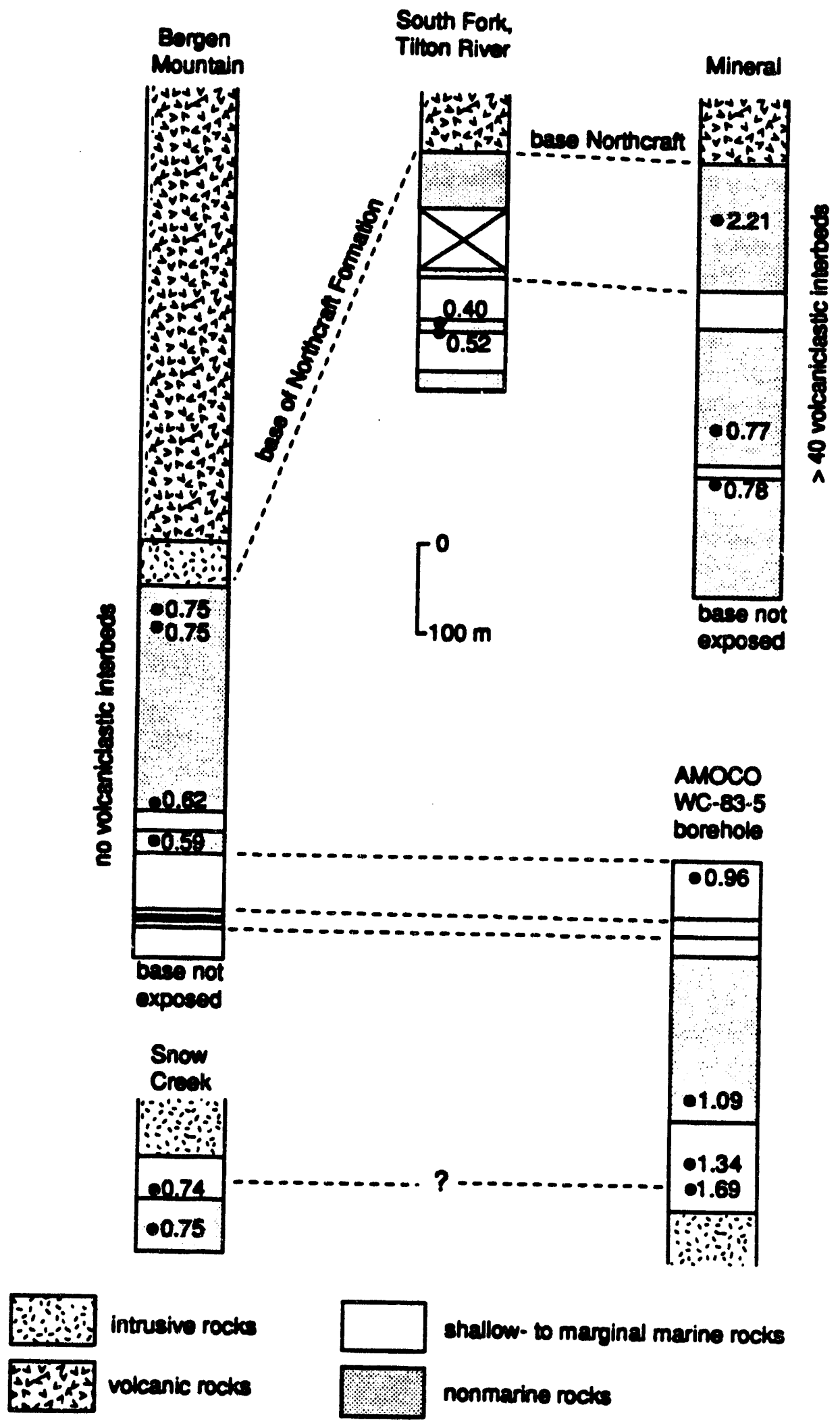

- mean vitrinite roflectanco

Figure 32 
area. This relationship is shown in Figure 32.

Correlation of the lower part of the Bergen Mountain section with the upper part of the AMOCO WC-83-5 borehole (Fig. 31) is based on a similar sequence of marinenonmarine-marine depositional intervals in the two sections. If this speculative correlation is correct, there is approximately $310 \mathrm{~m}$ of unmeasured strata between the Mineral section and the AMOCO WC-83-5 borehole section. Given these matches, the highest stratigraphic position that the Snow Creek measured section could occupy (Figure 34) is equivalent to the base of the AMOCO WC-83-5 borehole section. It could occur significantly lower in the stratigraphic sequence.

The South Fork of the Tilton River section is located $11 \mathrm{~km}$ from the Bergen Mountain section, $13 \mathrm{~km}$ from the Mineral section, and about $22 \mathrm{~km}$ from the Northcraft volcanic center of Hagen (1987; Fig. 2). Using the logic applied above regarding proximity to the Northcraft volcanic center, one might infer that the Carbonado-Northcratt contact in the South Fork of the Tilton River section should be higher than in the Bergen Mountain section. Placement of this contact at the same position as in the Mineral section is supported by a similar position of the highest nonmarine-marine facies boundary. This placement is also consistent with relatively low vitrinite reflectance values from the South Fork of the Tilton River section, indicating relatively less heating from burial and intrusions (despite a more eastern location closer to the axis of the Cascade Mountains) than in the Bergen Mountain section. Two factors argue against the high stratigraphic position of the South Fork of the Tilton River section: (1) The marine interval in the Mineral section is thinner than in the dominantly marine part (includes both marine intervals) of the South Fork of the Tilton River section. This contrast could reflect a major facies change, with a marine embayment lying south (South Fork Tilton River area) of a west-flowing delta lobe to the north (Mineral area). (2) The South Fork of the Tilton River section apparently lacks volcaniclastic interbeds. However, in that most of the well-exposed strata in this section have a marine origin (the upper nonmarine interval is very poorly exposed) and were subjected to significant sediment mixing by currents and bioturbation, this would not be unexpected.

Given these tentative correlations, there is a minimum of about $1200 \mathrm{~m}$ of stratigraphic section of the Carbonado Formation exposed at the surface or in the relatively shallow subsurface in the Morton antiform. 


\section{WHAT ROCKS UNDERLIE THE MORTON ANTIFORM?}

The discussion above indicates there is a minimum of about $1200 \mathrm{~m}$ of the Carbonado Formation exposed at the surface or in the relatively shallow subsurface in the Morton antiform. Three DOE seismic reflection lines $(1-2,4,5)$ cross the Morton antiform and reveal about 2.5 to 3 seconds of coherent reflectors beneath the Morton antiform. At typical expected velocities for these rocks (see earlier section on seismic velocity analysis) these reflectors probably represent about 4-5 kilometers of stratigraphic section. Structural complexity in the region makes analysis of seismic facies (e.g., Sangree and Widmier, 1977) difficult. Reflectors in the upper 2 seconds below the Morton antiform are continuous to discontinuous, have moderate to high amplitudes, and tabular to wedge-shaped external forms (Figure 17). These characteristics typify delta-plain-to-shelf depositional environments in which there is significant interbedding of different lithologies (i.e., mudstones and sandstones), a setting similar to that inferred above for the rocks at the surface and shallow subsurface in the Morton antiform. Seismic, surface outcrop, and borehole data thus indicate there is at least $4 \mathrm{~km}$ of Eocene deltaic strata in the Morton antiform.

The quality of seismic data below 2 seconds in the Morton antiform does not permit seismic facies analysis, nor does it allow accurate placement of the contact of the sedimentary sequence and its basement. Based on magnetotelluric data, Stanley and others (1992) showed a 3-4 km thick upper unit (30-40 ohm-m) in the Morton antiform (see MT model in Fig. 12) that is here interpreted as the deltaic sequence described above. Below this interval, Stanley and others (1992) recognized a thick (3-5 km) highly conductive (1-5 ohm-m) unit (Figs. 11 and 12) which they suggest is comprised of marine sedimentary rocks and corresponding to the SWCC. Regional geology and stratigraphy provide clues as to the nature of this lower unit in the Morton antiform area.

In the Tiger Mountain area about $100 \mathrm{~km}$ north of the Morton antiform, fluvialdeltaic rocks of the late middle Eocene Tiger Mountain Formation, similar in age and lithology to the Carbonado Formation in the Morton antiform, overlie early middle Eocene rocks of the Raging River Formation (Vine, 1969; Johnson, 1992; Fig. 5). The Raging River Formation consists of a diverse assemblage of rocks including fluvial conglomerates and relatively deep marine (upper to middle bathyal; water depths of $50 \mathrm{C}-2,000 \mathrm{~m}$ ) mudstones. The Raging River Formation has a minimum thickness of about $1,000 \mathrm{~m}$; its base is not exposed.

Snavely and others $(1951,1958)$ described the stratigraphy of the McIntosh Lake area, about $40-45 \mathrm{~km}$ west-northwest of the Morton antiform. In this area, the Mclntosh Formation ( $1.000 \mathrm{~m}$ thick, base not exposed) coarsens upward from dominantly marine mudstone in the lower part of the unit to fluvial-distributary channel deposits (i.e., the Tenino Sandstone) at the top of the unit. When compared with the benthonic foraminifera biofacies lists of Ingle (1980), foraminifera recovered from the Mclntosh marine mudstones suggest upper bathyal deposition (water depths of 150 to $500 \mathrm{~m}$ ) for the marine mudstones. The McIntosh Formation is overlain by volcanic rocks of the Northcraft Formation and deltaic rocks of the Skookumchuck 
Formation.

Relationships in both the Tiger Mountain and Mclntosh Lake area support both a regional and local (for the Morton area) paleogeographic model in which Eocene deltaic facies prograded to the west and southwest over fine-grained marine rocks. This transition occurred earlier in the Tiger Mountain area than in the Mclntosh Lake area because of its more northeastern location (Figs. 5). Fine-grained marine rocks of the Raging River and Mclntosh Formations are analogs for the deeply buried conductive rocks in the Morton antiform.

Could the entire SWCC in the Morton area and elsewhere be composed of these Eocene marine mudstones? If so, a complete section of Eocene strata at Morton would be at least $8 \mathrm{~km}$ thick. Correlative Eocene basins (for example, Swauk Basin, Chuckanut Basin, Puget Basin) in the Washington Cascades have transtenional origins and are characterized by thick sedimentary fills (commonly more than $5 \mathrm{~km}$ ) and rapid sediment accumulation rates (Johnson, 1985). These basins do not form major conductive anomalies, however they contain mainly norımarine rocks and they have been uplifted and eroded. Given a more outboard paleogeographic position and a different Neogene tectonic history (burial below the Cascades), they would be characterized by similar conductive anomalies. Regional relationships are thus consistent with origin of the Morton portion of the SWCC as a deeply buried Eocene marine mudstone unit in a transtensional basin. However, as discussed earlier, the deep units that appear to be thrust well eastward beneath pre-Tertiary rocks could be associated with a pre-Eocene subduction complex. 


\section{THE MORTON ANTIFORM HYDROCARBON PLAY}

Prospective hydrocarbon plays should include good (organic-rich and thermallymature) source rocks, reservoir rocks, and a viable trap and seal. In the following section we discuss these aspects of the Morton antiform area.

\section{Source rocks}

In the Morton area, the most likely source rocks are the Eocene marine mudstones that form at least the upper part of the SWCC. As discussed above, these strata were probably deposited at bathyal water depths in a prodeltaic setting. Strata of the Raging River Formation to the north and the McIntosh Formation to the west provide surface exposures of these facies (Fig. 5). There are very limited organic geochemical data from the Raging River Formation (Johnson, 1992), and no available data from the McIntosh.

For the Raging River Formation (Johnson, 1992), rock-eval pyrolysis shows that unit 3 bathyal mudstone from the AMOCO WC-83-14 core are now overmature with respect to hydrocarbon generation $\left(T_{\max }=533^{\circ}-542^{\circ}\right.$ for three samples) and thus cannot be reliably evaluated as petroleum source rocks (Peters, 1986). Vitrinite reflectance values in five samples from this core range from $1.96 \pm 0.33$ (depth of $498 \mathrm{~m}$ ) to $1.65 \pm 0.08$ (depth of $69 \mathrm{~m}$ ) and similarly indicate overmaturity. Despite these indicators of high thermal maturity, there is still as much as 0.8-0.9 percent total organic carbon in fine-grained marine rocks of the Raging River Formation. This remnant organic content is an indication that the rocks were once more organic rich and capable of generating hydrocarbons. The common occurrence of terrestrial organic matter in the organic-rich mudstones is consistent with their inferred prodeltaic setting, and suggests they would be gas-prone source rocks.

Coals and carbonaceous shales in the deltaic upper sedimentary unit of the Morton antiform might also be viable gas-prone source rocks. These mainly nonmarine organic-rich rocks do not represent a large volume of strata in the measured sections (Appendix B).

The thermal maturity of organic-rich rocks in the Morton antiform is both laterally and vertically variable and appears to be related to heat sources from burial, local intrusions, and possibly heating from overlying volcanic flows. Vitrinite reflectance values from the measured sections (Fig. 8; Appendix A) illustrate this complex thermal regime. In samples from the AMOCO WC-83-5 borehole, there is a rapid decrease in mean vitrinite reflectance $\left(R_{m}\right)$ above the intrusion that occurs at the base of the borehole, from 1.69 percent at about $30 \mathrm{~m}$ above the intrusion to 1.09 percent about $130 \mathrm{~m}$ above the intrusion. The steep thermal gradient associated with this intrusion was also noted by Esposito (1993) based on clay-mineral reactions. $R_{m}$ in a sample from near the top of the $400 \mathrm{~m}$ core 10.96 percent) indicates a much lower paleo-geothermal gradient that was probably mainly controlled by burial. This burial-related gradient appears to continue upward and include the two samples in the overlying Mineral section ( $R_{m}=0.77$ and 0.78 percent). However, the highest sample in that section yielded a $R_{m}$ of 2.21 percent. The only viable explanation for 
this anomalously high value is proximity to a nearby, concealed intrusion.

Farther south, the lowest four samples in the Bergen Mountain-Snow Creek area (Fig. 34) suggest a shallow paleo-geothermal gradient that was mainly controlled by burial (values of 0.74 to 0.62 percent). There does not appear to be a significantly elevated paleo-geothermal gradient associated with the thick intrusion $(>130 \mathrm{~m})$ that caps the short Snow Creek section. In contrast, the 45-m-thick intrusion that caps the Bergen Mountain section has resulted in a notable inversion of Rm, with higher values at 25 and $50 \mathrm{~m}$ below the top of the section $(0.74$ and 0.75 percent) than at about 250 and $300 \mathrm{~m}$ below the top of the section (0.62 and 0.59 percent). These $\mathrm{Rm}$ measurements indicate that the thermal effects of different intrusions in the Morton area varies significantly, based on a combination of intrusion depth, thickness, and composition.

The lowest $R_{m}$ values in the Morton antiform are from the South Fork of the Tilton River section (0.40 and 0.52 percent). These samples lie closest to the axis of the Cascade Range and therefore should have been subjected to the highest regional thermal gradients (Walsh and Lingley, 1991). Their relatively low values indicate that they were either not buried as deeply or that they have been consistently isolated from centers of intrusive activity, such as that associated with the volcanic Northcraft Formation (Hagen, i987).

Although thermal maturity varies significantly in rocks at or near the surface in the Morton antiform, most rocks are near the lower part of or well within the hydrocarbon-generating wiridow (Tissot and Welte, 1978). Based on limited data, thermal maturity in the Morton antiform locale appears to increase westward, possibly controlled by proximity to the intrusive center for the Northcraft Formation. Depending on their depth of burial and proximity to intrusions, source rocks in the Morton antiform subsurface might yield either wet or dry gas. Maximum burial and gas generation/migration probably occurred in the late Oligocene or early Miocene (Walsh and Lingley, 1991). Possible deeper source rocks may exist to the east in the lower parts of the SWCC that are inferred to include subduction complex units. For these hypothesized units a higher heat flow and deeper burial mean that the units would have been sourcing hydrocarbons during and prior to the late Oligocene and Miocene, but likely at highest rates prior to formation of the Morton antiform. For the latter reasons, it may be unlikely that any hydrocarbons sourced from these deeper, eastern sedimentary rocks were retained within the Morton antiform.

\section{Reservoir rocks}

Beds of fine- to coarse-grained sandstone of fluvial-distributary channel origin (see above) comprise the best reservoir rocks in the strata exposed at the surface or in the shallow subsurface. These channel bodies are typically 5-20 m thick, but can be as thick as $70 \mathrm{~m}$. Given their inferred deltaic setting, they probably have ribbon geometry, elongate east to west. Shallow-marine sandstone beds within the described section are typically heavily bioturbated and less viable source rocks. There could be bathyal turbidite sandstones in deeper subsurface (the SWCC) below the Morton antiform, but this hypothesis can only be tested by drilling.

No quantitative porosity and permeability data have been collected from the 
fluvial-distributary channel sandstone bodies in the described sections. In four of the five measured sections, these bodies are typically well cemented. In the South Fork of the Tilton River section, however, sandstone bodies are notably friable and porous.

Preliminary petrographic analysis of just 4 samples from fluvial-distributary sanidstone bodies in the AMOCO WC-83-5 borehole reveals arkosic compositions (mean QFL of 38, 39, 23) consistent with compositions of Eocene fluvial and deltaic sandstones elsewhere in western Washington (Buckovic, 1978; Frizzell, 1978; Johnson, 1985). Lithic fragments are primarily volcanic and sedimentary in origin. These samples have minimal porosity ( $<5$ percent) and significant calcite cement and clay pseudomatrix. Pseudomatrix was mainly produced by alteration of lithic fragments and detrital mafic minerals.

Given the available data, it is difficult to predict porosity and permeability in the subsurface. Sands of similar composition interbedded with rocks of low thermal maturity $\left(0.5\right.$ percent $>R_{m}$ ) are gas reservoirs at the Mist Field in northwestern Oregon (Armentrout and Suek, 1985) and gas-storage reservoirs in the nearby Chehalis Basin (Fig. 4). One would expect greater breakdown of detrital grains and increased circulation of cementing diagenetic fluids with higher thermal maturities and proximity to intrusions, factors that appear to characterize most of the Morton antiform. It may be that secondary porosity is needed to produce viable reservoirs in the subsurface of the Morton antiform.

\section{Trap and seal}

The Morton antiform is not a simple anticline. Rather, it is a structurally high area where middle Eocene sedimentary rocks have been brought to the surface through a complex network of folds and faults (Schasse, 1987). Several relatively small-scale structural traps might be present along crests of small.anticlines or in small fault blocks as at the Mist gas field in northwest Oregon (Armentrout and Suek, 1985). The maximum closure based upon the seismic data interpretation (Fig. 31) is about 2000', but actual traps are likely thinner than this. Stratigraphic traps or combined structural-stratigraphic traps might be present where fluvial-distributary channel sandstones pinchout against interbedded fine-grained rocks.

Prior to Miocene and younger uplift and erosion, volcanic rocks of the Northcraft and Ohanapecosh Formations covered the Morton antiform area and would have provided a highly effective seal. After removal of this regional seal, local seals might have been provided by impermeable mudstone and volcaniclastic strata, and by intrusions. The abundant faults in the Morton antiform would have a negative impact on preserving the integrity of both traps and seals. 


\section{SUMMARY AND CONCLUSIONS}

Extensive geophysical studies have outlined a anomalous part of the Earth's crust in the southern Washington Cascades region. Seismic reflection surveys were designed from MT, gravity, and magnetic models. The seismic data were obtained where there were no previous results, and although the data were of marginal quality much was learned about the application of seismic methods in volcanic areas. Future studies in such areas should involve mole testing of dynamite source methods, wideline-profiling, wide-angle shooting, and other innovative techniques designed to obtain deep images of the earth in complex geological settings. Standard industry exploration methods will not achieve the type of information required in frontier areas such as that of the SWCC region.

The effectiveness of the MT method was well demonstrated and models computed for this complex geological region were found to essentially agree with key details of an extensive deep seismic reflection survey. In areas where no wells were available it would have been impossible to sort out any lithological information from the seismic data alone, but with a combination of MT, gravity, magnetic, seismicity, and seismic reflection data, a detailed tectonic/stratigraphic model has been developed. This model draws heavily upon geological and geophysical information from the Chehalis Basin and other nearby basins, but remains to be tested with drilling. A proposed 15,000' drill hole to be completed by Hunt Oil Co. in 1994 should answer key questions about the Morton antiform in detail and provide ground truth for our proposed broader models of the region. Maximum benefit from this well could be obtained by intensive analysis of core and cuttings as well as geochemical sampling while drilling of both gases and bore fluids. Hunt Oil has suggested that it will provide core and cuttings to the USGS for future studies. In addition, the USGS can be available for continuous gas sampling during the drilling and completion of the hole.

A detailed stratigraphic and play analysis of the Morton antiform area was completed for this report, using new data acquired under the USGS Evolution of Sedimentary Basins program. This particular play analysis represents the end member in a program of frontier research using reconnaissance geophysics to identify areas where deeply sourced methane may be trapped in shallow structures. It seems likely that there are viable gas-prone source rocks beneath the Morton antiform and possible deeper units may occur to the east in lateral parts of the SWCC. The presence of reservoir-quality sandstones in the deeper (>1,000 m?) subsurface of the Morton antiform is probably dependent on isolation from intrusions and(or) developmer $\hat{\imath}$ of secondary porosity. The abundant small-scale deformation iri the Morton antiform has probably had a strong negative effect on hydrocarbon trapping and sealing mechanisms. 


\section{ACKNOWLEDGMENTS}

The authors wish to thank a number of individuals who contributed to our understanding of the SWCC region and more directly to materials used in this report. Bill Lingley and Tim Walsh, Washington Department of Natural Resources, provided a great deal of essential information on well locations, well reports, and general geological information. Carol Finn, USGS, has worked for several years on analyzing gravity and magnetic data for the region and provided most of the models for these data sets referenced in this and earlier reports on the region. Gerda Abrams, USGS, reduced and processed the aeromagnetic survey funded by DOE. Gary Latham and Keith Westhusing planned much of the seismic survey and bird-dogged the field acquisition. Rick Steinik and others at Golden Geophysical played a key role in allowing high-quality processing of DOE seismic lines 1,2, and 3. John Contino, Geotrace Technologies was responsible for processing seismic lines 4,5, and 6. Tom Ise, Consulting Geologist, aided our initial understanding of the Chehalis Basin with his 1985 publication and personal discussions. We are grateful to L. B. Industries for providing seismic reflection data in the Carbon River antiform. Tom Mroz, DOE, provided digitized sonic logs from key wells. Nick Zilman, USGS, produced the very useful seismic data CD-ROM and associated users software. Lastly and most importantly, W. J. Gwilliam Deep Gas Project manager, made this research, possible with his unflagging enthusiasm for the potential of finding large volumes of unknown gas source rocks in the western U.S. Cordillera. 


\section{REFERENCES}

Abrams, Gerda, 1992, Aeromagnetic survey of the Morton, Washington are: U.S. Geological Survey Open-File Rept. 92-251.

Acuna, M. H., Searce, C. S., Seek, J. B. and Scheifele, J., 1973, The MAGSAT vector magnetometer-a precision fluxgate magnetometer for the measurement of the geomagnetic field: Technical Memorandum No. 79656, NASA Goddard Space Flight Center, Greenbelt, Maryland, 18 pp.

Anstey, Nigel A., 1977, Seismic interpretation: the physical aspects: International Human Resources Development Corporation, Boston, MA, 625 p.

Armentrout, J.M., and Suek, D.H., 1985, Hydrocarbon exploration in western Oregon and Washington: American Association of Petroleun I Geologists Bulletin, v. 69, p. 627-643.

Babcock, R.S., Burmester, R.F., Engebretson, E.C., an 1 Warnock, A., 1992, A rifted origin for the Crescent basalts and related rock: in the northern Coast Range volccinic province, Washington and British Coluınbia: Journal of Geophysical Research, p. 6,799-6,821.

Barnett, D. B. and M. A. Korosec, 1989, Results of the 1988 geothermal gradient test drilling project for the State of Washington: Washington Division of Geology and Earth Resources, Open-File Report 89-2, 54 p.

Belt, E. S., 1968, Post-Acadian rifts and related facies, eastern Canada: in Zen, E-An, White, W. S., Hadley, J. B., and Thompson, J. B., eds., Studies in Appalachian geology, Northern and Maritime, New York, Interscience, p. 95-113.

Blackwell, D. D., J. L. Steele, and S. A. Kelley, 1985, Heat flow and geothermal studies in the State of Washington: U.S. Department of Energy Report ID/12307-1, 77pp.

Blackwell, D. D., and J. L. Steele, 1983, A summary of heat flow studies in the Cascade Range: Transactions of the Geothermal Resources Council, v. 7, p. 233-2j6.

Boswell, R., Wilson, T.W., and Donaldson, A.C., 1988, Evaluation of a seismic line across the Puget downwarp, southwestern Washington: DOE Final Report, 24 p.

Braislin, D. B., D. D. Hastings, and P. D. Snavely, Jr., 1971, Petroleum potential of western Oregon and Washington and adjacent continental margin: in Future Petroleum Provinces of the United States-Their Geology and Potential: American Association of Petroleum Geologists Memoir 15, v. 1, 229-238.

Brown, L. F., Jr., and W. L. Fisher, 1979, Principles of seismic stratigraphic interpretion; Interpretaion of depositional systems and lithofacies from seismic data: Seismic stratigraphic interpretation and petroleum exploration: AAPG Continuing Education Course Notes Series \#16, University of Texas at Austin, $56 \mathrm{p}$.

Brown and Ruth Laboratories, Inc., 1982, Pacific Northwest Regional petroleum geochemistry of the onshore and offshore sediments of Washington and Oregon-Pan American Petroleum Company OCS-P-0141, offshore Jefferson 
County, Washington:

Buckovic, W.A., 1978, The Eocene deltaic systm of west-central Washington, in Armentrout, J.M., Cole, M.R., and TerBest, H. Jr., Cenozoic Paleogeography of the western United States: Society of Economic Palentologists and Mienralogists, Pacific Section, p. 147-164.

Cady, W. M., 1975, Tectonic setting of the Tertiary volcanic rocks of the Olympic Peninsula, Washington: U.S. Geological Survey Journal of Research, v. 3, p. 573-582.

Carey, S. W., 1958, A tectonic approach to continental drift: in Carey, S. W., ed., Continental drift: A symposium, University of Tasmania, p. 177-355.

Clarke, J., Gamble, T.D., Goubau, W.M., Koch, R.H. and Miracky, R.F., 1983, Remote-reference magnetotellurics: equipment and procedures, Geophys. Prospecting, 31, 149-170.

Clowes, R.M., Brandon, M.T., Green, A.G., Yorath, C.J., Sutherland Brown, A., Kanasewich, E.R., and Spencer, C., 1987, LITHOPROBE - Southern Vancouver Island: Cenozoic subduction complex imaged by deep seismic reflections: Canadian Journal of Earth Sciences, v. 24, p. 31-51.

Cordier, J. -P., 1985, Velocities in Reflection Seismology: Reidel, Dorcrecht, 201 pp.

Davis, G. D., J. W. H. Monger, and B. C. Burchfiel, 1978, Mesozoic construction of the Cordilleran "Collage", central British Columbia to central California: in Mesozoic Paleogeography of the Western United States: Pacific Section, Society of Economic Paleontologists and Mineralogists, Pacific Coast Paleogeography Symposium 2, Los Angeles, p. 33-70.

Dietz, Lynn D., and W. L. Ellsworth, 1990, The October 17, 1898 Loma Prieta, California, earthquake and its aftershocks: geometry of the sequence from highresolution locations: Geophysical Research Letters, v. 17, no. 8, p. 1353-1359.

Dobrin, M. B., and Savit, C. H., 1988, Introduction to Geophysical Prospecting: Fourth Edition, McGraw-Hill, New York, 867p.

Eisbacher, G. H., 1985, Pericollisional strike-slip faults and synorogenic basins, Canadian Cordillera: in Biddle, K. T., and Nicholas Cristie-Blick, eds., Strike-slip Deformation, Basin Formation, and Sedimentation, Society of Economic Paleontologists and Mineralogists Special Publication 37, p. 265-282.

Ellingson, J. A., 1972, The rocks and structure of the White Pass area, Washington: Northwest Science, v. 46, p. 9-24.

Ellingson, J. A., 1972, The rocks and structure of the White Pass area, Washington: Northwest Science, v. 46, p. 9-24.

Esposito, K.J., 1993, Thermal effects of thin igneous intrusions on the illitization reaction in a Tertiary basin, southwestern Washington state [M.S. thesis]: Golden, Colorado School of Mines, 142 p.

Evans, J. E., 1988, Depositional environments, basin evolution, and tectonic significance of the Eocene Chumstick Formation, Cascade Range, Washington: unpublished Ph.D. thesis, University of Washington, Seattle, 325 p.

Evans, J. E., and S. Y. Johnson, 1989, Paleogene strike-slip basins of central Washington: Swauk and Chumstick Formations: in N. L. Joseph and others, 
eds., Geologic Guidebook for Washington and Adjacent Areas, Washington Division of Geology and Earth Resources Information Circular 86.

Finn, C. A., 1989, Structure of the convergent Washington margin: in Proceedings of the Workshop XLIV Geological, Geophysical, and Tectonic Setting of the Cascade Range, U.S. Geological Survey Open-File Rept. 89-178, p. 291-317.

Fisher, R.V., 1957, Stratigraphy of the Puget Group and Keechulus group in the ElbePackwood area of southwestern Washington [Ph.D. thesis]: Seattle, University of Washington, 157 p., 10 plates.

Fitterman, D. V., W. D. Stanley, and R. J. Bisdorf, 1988, Electrical structure of Newberry volcano: Journal Geophysica; Research, 93, p. $10120-10131$.

Frizzeli, V.A., Jr., 1978, Petrology of Paleogene nonmarine sandstones in Washington, in Armentrout, J.M., Cole, M.R., and TerBest, H. Jr., Cenozoic Paleogeography of the western United States: Society of Economic Palentologists and Mienralogists, Pacific Section, p. 113-118.

Galloway, W. E., 1974, Deposition and diagenetic alteration of sandstone in northeast Pacific arc-related basins: implications for graywacke genesis: Geological Society of America Bulletin, 85, 379-390.

Gamble, T.D., Goubau, W.M. and Clarke, John, 1979, Magnetotellurics with a remote reference, Geophysics, 44, 53-68.

Gard, L.M., 1968, Bedrock geology of the Lake Tapps Quadrangle, Pierce County, Washington: U.S. Geological Survey Professional Paper 388-B, p. B1-B33.

Gimlin, D. R. and J. W. Smith, 1980, A comparison of seismic trace summing techniques: Geophysics, v. 45, p. 1017-1041.

Globerman; B. R., and M. E. Beck, Jr., 1979, Cenozoic tectonic rotations in the western cordillera: new evidence from the Washington Coast Range: EOS, Transactions of the American Geophysical Union, 60, 816.

Grau, G., 1993, Seismic velocities in complex media: Journal of Applied Geophysics, $29,271-284$.

Gregory, A. R., 1977, Aspects of rock physics from laboratory and log data that are important to seismic intepretation: in Seismic Stratigraphy -Applications to Hydrocarbon Exploration, p. 15-46, ed. C. E. Payton, AAPG, Tulsa, Memoir 26.

Gwilliam: W. J., 1990, Deep Gas Technology Status Report: Morgantown Energy 'Tecinnology Center Report 90/0271, U.S. Department of Energy.

Hagan, R.A., 1987. The geology and petrology of the Northcraft Formation, Lewis Bounty, Washington [M.S. thesis]: Eugene, University of Oregon, 252 p.

Fiv. P. D., 1991, Petroleum geology of the Bellingham Basin, Washington and evaluation of the AHEL and Partners Birch Bay No. 1 well: Washington Geology, 19, 16-18.

Hedges, Joseph W., 1949, A geology of the Bear Canyon area: M.S. Thesis, College of Puget Sound.

Henriksen, D.A., 1956, Eocene stratigraphy of the lower Cowlitz River-easterin Willapa Hills area, southwestern Washington: Washington Division of Mines and Geology Bulletin 43, 122 p.

Hilde, T. W.C., 1983, Sediment subduction versus accretion around the Pacific: in 
Tectonophysics, Convergence and Subduction, T.W.C. Hilde and S. Uyeda, eds. Ingle, J.C., Jr., Cenozoic paleobathymetry and depositonal hisotry of selected sequences within the southern California continental borderland: Cushman Foundation Special Publication 19, p. 163-195.

Ise, F. T., 1985, Washington and Oregon-are there other rocks to explore: Oil and Gas Journal, August 12, p. 112-115.

Johnson, S.Y., 1984, Evidence for a margin-truncating transcurrent fault (pre-Late Eocenel in western Washington; Geology, v. 12, p. 538-541.

Johnson, S.Y., 1985, Eocene strike-slip faulting and nonmarine basin formation in Washington, in Biddle, K.T., and Christie-Blick, Nicholas (eds.), Strike-slip deformation, basin formation, and sedimentation: Society of Economic Paleontologists and Mineralogists, Special Publication 37, p. 283-302.

Johnson, S.Y., 1992, Stratigraphy and sedimentology of the Raging River Formation (ẹarly? and middle Eocene), King County, Washington: U.S. Geological Survey Open-File report 92-581, $38 \mathrm{p}$.

Johnson, S.Y., and.Yount, J.C., Toward a better udnerstanding of the Paleogene paleogeography of the Puget Lowland, western Washington. Geological Society of America Abstracts with Programs, v. 24, p. 36.

Johnson, S.Y., 1993, Analysis of Cenozoic subsidence at three sites in the Seattle basin area, Washington: U.S. Geological Survey Open-File Report 93-332, 17 p.

Johnson, S.Y., Potter, C.J., and Armentrout, J.M., 1994 (in press), Origin and evolution of the Seattle basin and Seattle fault: Geology, v. 24, p.

Kleinhous, L. C., E. A. Balcells-Baldwin, and Jones, R. E., 1984, A paleogeographic reinterpretation of some middle Cretaceous units, north-central Oregon: Evidence for a submarine turbidite system: in Nilsen, T. H., ed., Geology of the Upper Cretacéous Hornbrook Formation, Oregon and California: Society of Economic Paleontologists and Mineralogists, Pacific Section, Field Trip Guidebook 42, p. 239-257.

Krehbiel, S., 1993a, Seismic, maturity data point to S.W. Washington potential: Oil and Gas Journal, 91, no. 12, p. 107-111.

Krehbiel, S., 1993b, Depth estimates of seismic reflection data in SW Washington: The Leading Edge, p. 1076-1081.

Kvenvolden, K. A. and P. D. Snavely, Jr., 1987, Hydrocarbon generation at the convergent margin of coastal Washington and Oregon: in Procedings of the Unconventioanl Gas Recovery Contractors Review Meetin, ed. C. A. Komar, U.S. Department of Energy, Morgantown Energy Technology Center Report 87/6080, p. 137-148.

Lee, C. D., F. D. Vine, and R. G. Ross, 1983, Electrical conductivity models for the continental crust based upon laboratory measurements on high grade metamorphic rocks: Geophysical Journal of the Royal Astronomical Society, $v$. 72, p. 353-371.

Magill, J., A. Cox, and R. Duncan, 1981, Tillamook volcanic series: further evidence for tectonic rotation of the Oregon Coast Range: Journal of Geophysical 

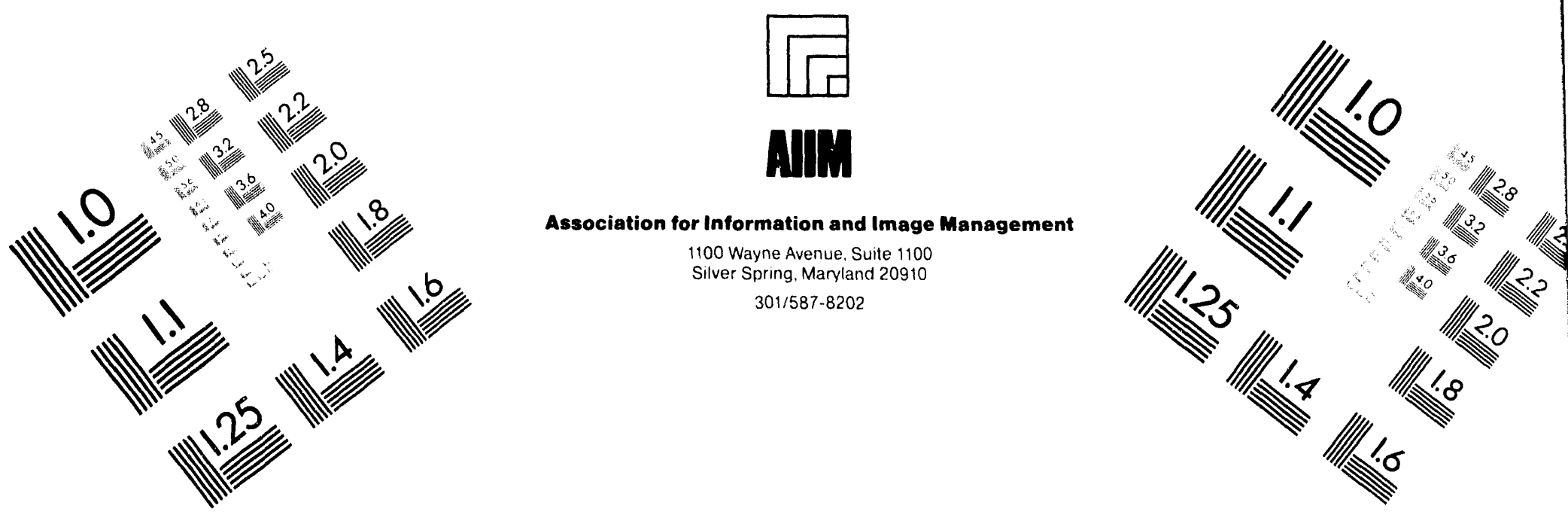

\section{Centimeter}

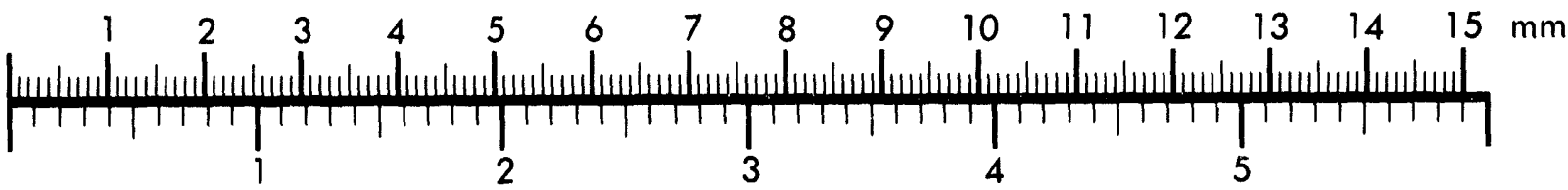
Inches
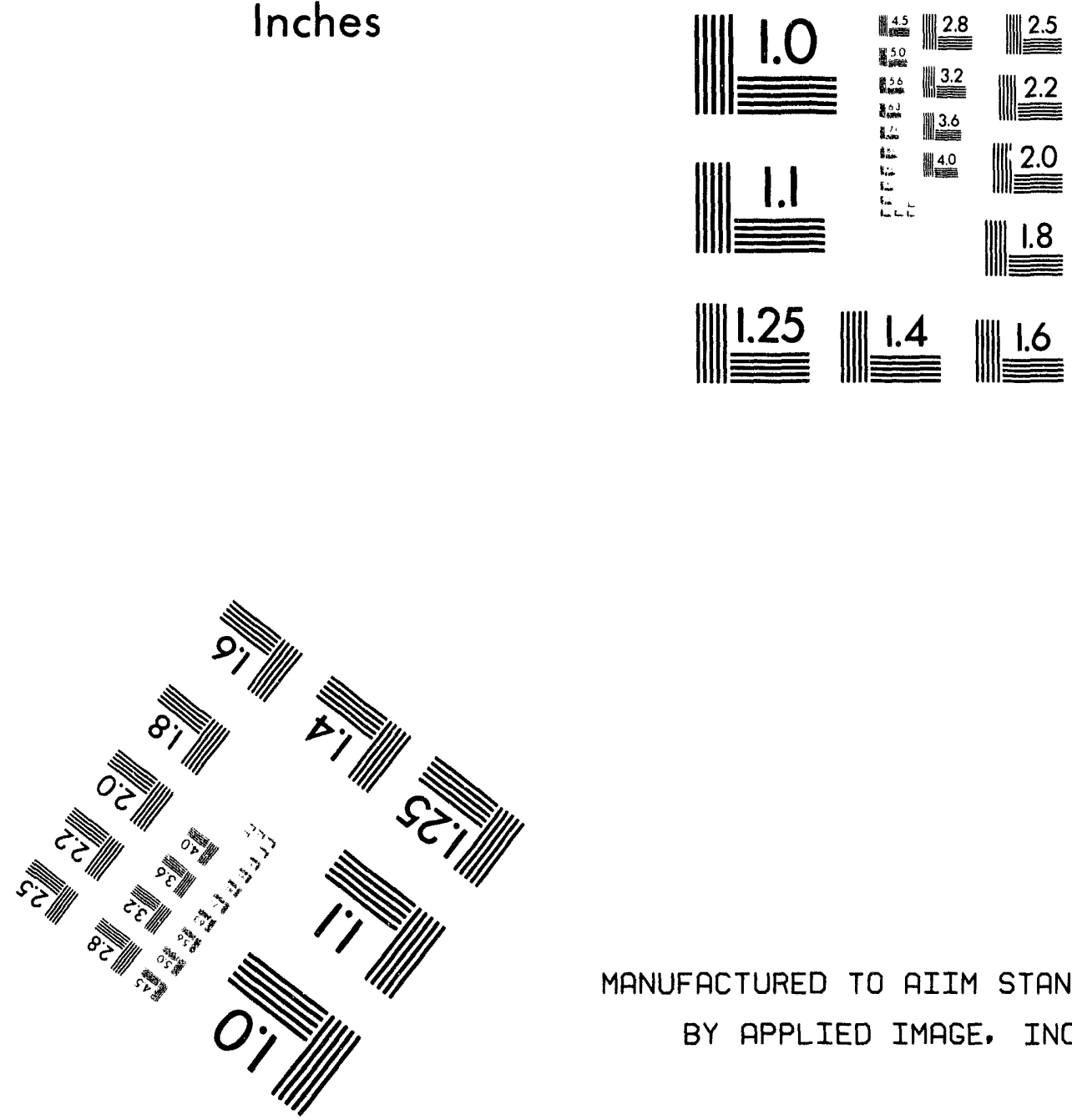

MANUFACTURED TO AIIM STANDARDS BY APPLIED IMAGE. INC.

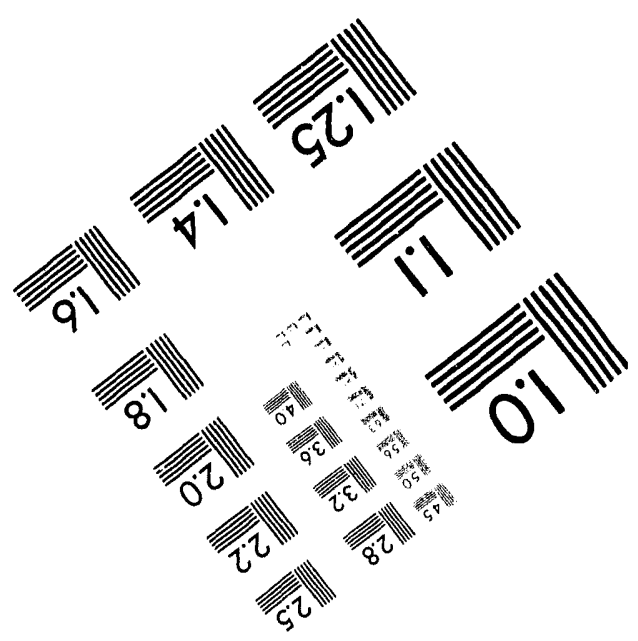



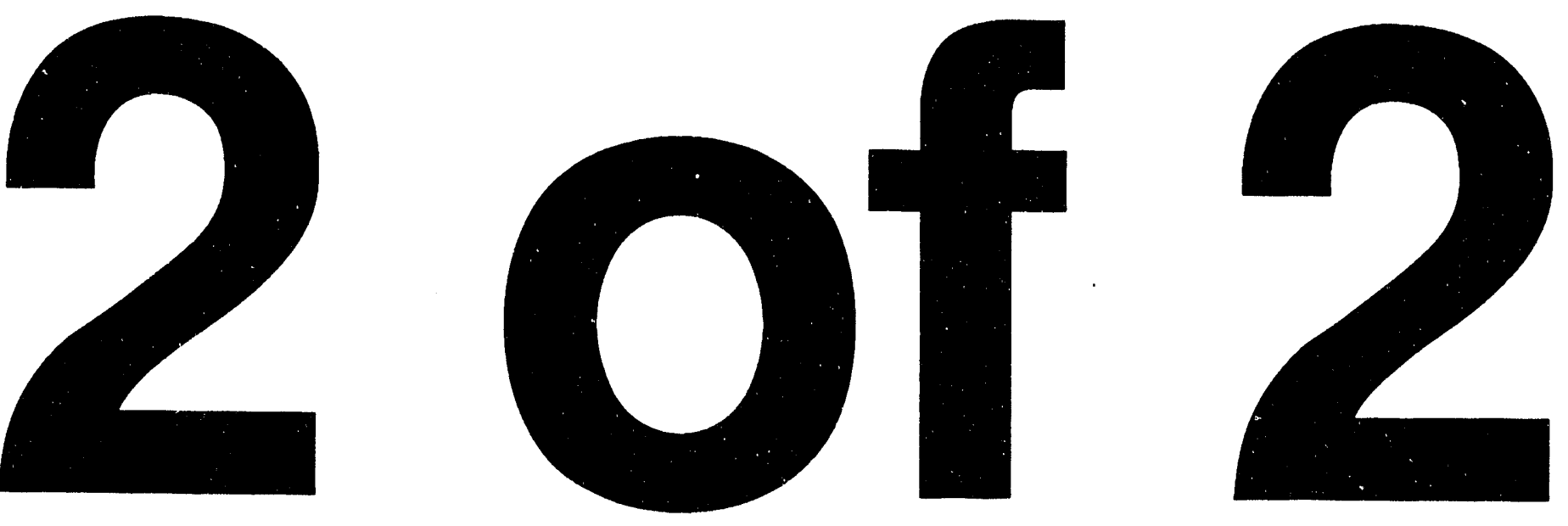
Research, 86, 2953-2970.

McKee, E. H., D. A. Swanson, and T. L. Wright, 1977, Duration and volume of Columbia River Basalt volcanism, Washington, Oregon, and Idaho: (abs) Geological Society of America Abs. with Programs, 9, 463-464.

Michon, D., 1993, Reconnaissance profiles with WLP in complex geological regions: Journal of Applied Geophysics, 29, 285-300.

Miller, R.B., 1989, The Mesozoic Rimrock Lake inlier, southern Washington Cascades implications for the basement to the Columbia embayment: Geological Society of America Bulletin, v. 101, p. 1289-1305.

Miller, R.B., Mattinson, J.M., Funk, S.A.G., Hopson, C.A., and Treat, C.L., 1993, Tectonic evolution of Mesozoic rocks in the southern and central Washington Cascades, in Dunn, E.G., and McDougall, K., eds., Mesozoic paleogeography of the western United States - II: Pacific Section SEPM, Book 71, p. 81-98.

Misch, Peter, 1977, Dextral displacements at some major strike faults in the North Cascades: (abs), Geological Society of Canada. Programs with Abstracts, p. 37.

Mitchum, R. M., Jr., P. R. Vail, and J. B. Sangree, 1977, Stratigraphic interpretation of reflection patterns in depositional sequences: in Seismic Stratigraphy Applications to Hydrocarbon Exploration, p. 117-134, ed. C. E. Payton, AAPG, Tulsa, Memoir 26.

Muller, J. E., 1977, Evolution of the Pacific margin, Vancouver Island, and adjacent regions: Canadian Journal of Earth Sciences, v. 14, no. 9, p. 2062-2085.Geological Survey of Canada, Paper 69-25, 77 p.

Mullineaux, D. R., 1970, Geology of the Renton, Auburn, and Black Diamond quadrangles, King County, Washington: U.S. Geological Survey Professional Paper no. 672, 92 p.

Nicholsen, Craig, L. Seeber, P. Williams, and L. R. Sykes, 1986, Seismicity and fault kinematics through the eastern Transverse Ranges, California: block rotation, strikeslip faulting and low-angle thrusts: Journal of Geophysical Research, 91, B5, 4891 4908.

Northwest Oil Report, 1983, Shell confirms Saddle Mountain Flaring: v. 25, no. 19, Portland, Oregon.

Olhoeft, G. R., 1985, Low-frequency electrical properties: Geophysics, 50, no. 12 , 2492-2503.

Olmstead, D. L., 1989, Hydrocarbon exploration and occurrences in Oregon: Oregon Department of Geology and Mineral Industries, Oil and Gas Investigation No. 15. Portland, $78 \mathrm{p}$.

Peters, K.E., 1986, Guidelines for evaluating petroleum source rock using programmed pyrolysis: American Association of Petroleum Geologists Bulletin, v. 70, p. 318329.

Phillips, W. M. and T. J. Walsh, 1989, Eocene transition from oceanic to arc volcanism, southwest Washington: in Proceedings of Workshop XLIV, Geological, Geophysical, and Tectonic Setting of the Cascade Range, U.S. Geological Survey Open-File Report No. 89-178 p. 199-256.

Price, R. A., J. W. H. Monger, and J. A. Roddick, 1985, Cordilleran cross-section; 
Calgary to Vancouver: Trip No. 3 in Field Guides to Geology and Mineral Deposits in the Southern Canadian Cordillera, Geological Survey of America, Cordilleran Section Meeting, Vancouver, B.C., Edited by Dirk Tempelman-Kluit.

Rau, W.W., and Armentrout, J.M., 1983, Grays Harbor basin, in Armentrout, J.M., Hull, D.A., Beaulieu, J.D., and Rau, W.W., eds., Correlation of Cenozoic stratigraphic units of western Oregon and Washington: Oregon Department of Geology and Mineral Industries Oil and Gas Inestigation 7, p. 56-59.

Rau, W.W., Armentrout, J.M., and Easterbrook, D.J., 1983, Centralia Chehalis area, in Armentrout, J.M., Hull, D.A., Beaulieu, J.D., and Rau, W.W., eds., Correlation of Cenozoic stratigraphic units of western Oregon and Washington: Oregon Department of Geology and Mineral Industries Oil and Gas Inestigation 7, p. 60-63.

Sangree, J.B., and Widmier, J.M., 1977, Seismic interpretation of depositional facies, in Payton, C.E., ed., Seismic stratigraphy - applications to hydrocarbon exploration: American Association of Petroleum Geologists Bulletin, Memoir 26, p. 165-184

Schasse, H.W., 1987, Geologic map of the Centralia Quadrangle, Washington: Washington Divsion of Geology and Earth Sciences Open-File Report 87-11, 27 p. text, scale, 1:100,000.

Sheriff, R. E., 1984, Encyclopedic Dictionary of Exploration Geophysics: Soc. Explor. Geophys., Tulsa, 2nd ed., 323 pp.

Simpson, R. W., and A.V. Cox, 1977, Paleomagnetic evidence for tectonic rotation of the Oregon Coast Range: Geology, 5, 585-589.

Snavely, P.D., Jr., 1987, Tertiary geologic framework, neotectonics, and petroleum potential of the Oregon-Washington continental margin, in Scholl, E.W., Grantz, A., and Vedder, J.G., eds., Geology and resource potential of the continental margin of western North America and adjacent ocean basins, Beaufort Sea to Baja California: Circum-Pacific Council for Energy and Mineral Resources, Earth Science Series, v. 6, p. 305-335.

Snavely, P. D., Jr., N. S. MacLeod, and H. C. Wagner, 1968, Tholeitic and alkalic basalts of the Eocene Siletz River Volcanics, Oregon Coast Range: American Journal of Science, v. 266, p. 454-481.

Snavely, P.D., Jr., Brown, R.D., Jr., Roberts, A.E., and Rau, W.W., 1958, Geology and coal resources of the Centralia-Chehalis district, Washington: U.S. Geological Survey Bulletin 1053, $159 \mathrm{p}$.

Snavely, P.D., Jr., Rau, W.W., Hoover, L. Jr., and Roberts, A.E., 1951, Mclntosh Formation, Centralia-Chehalis coal district, Washington: American Association of Petroleum Geologists Bulletin, v. 35, p. 1052-1061.

Stanley, W. D., D. B. Jackson, and A. A. R. Zohdy, 1976, Deep electrical investigations in the Long Valley geothermal area, California: Journal of Geophysical Research, 81, p. 810-820.

Stanley, W. D. and Tinkler, R. D., 1983, A practical, low-noise coil system for magnetotellurics: U.S. Geological Survey Open-File Report 83-85, 18 pp.

Stanley, W.D., Finn, C., and Plesha, J.L., 1987, Tectonics and conductivity structures in the southern Washington Cascades: Journal of Geophysical Research, v. 81, p. 810-820. 
Stanley, W. D., G. S. Fuis, and W. D. Mooney, 1989, Details of crustal structure in the Cascade Range and surrounding regions from seismic and magnetotelluric data: in Proceedings of Workshop XLIV, Geological, Geophysical, and Tectonic Setting of the Cascade Range, U.S. Geological Survey Open-File Report. 89-178.

Stanley, W.D., Gwilliam, W.J., Latham, F., and Westhusing, K., 1992, The southern Washington Cascade conductor -- A previously unrecognized thick sedimentary sequence? American Association of Petroleum Geologists Bulletin, v. 76, p. 1569 1585.

Stanley, W. D., V. F. Labson, W. J. Nokleberg, Bela Csejtey, Jr., and M. A. Fisher, 1990, The Denali fault system and Alaska Range of Alaska: evidence for underplated Mesozoic flysch from magnetotelluric surveys: Geological Society of America Bulletin, 102, 160-173.

Sternberg, B. K., J. C. Washburne, and L. Pellerin, 1988, Correction for the static shift in magnetotellurics using transient electromagnetic soundings: Geophysics, v. 53, p. 1459-1468.

Stockwell, John, 1993, Complete listing of CWP Public Domain Program SelfDocumentation: Center for Wave Phenomiena, Colorado School of Mines, Golden, Colorado.

Tabor, R. W., R. B. Waitt, V. A. Frizzell, D. A. Swanson, G. R. Byerly, R. D. Bentley, 1982, Geologic map of the Wenatchee 1:100,000 quadrangle, Washington: U.S. Geological Survey, Miscellaneous Investigation Series Map i-1311, 26 p., 1 plate.

Tabor, R. W., V. A. Frizzell, Jr., J. A. Vance, and C. W. Naeser, 1984, Ages and stratigraphy of lower and middle Tertiary sedimentary and volcanic rocks of the central Cascades, Washington: application to the tectonic history of the Straight Creek fault: Geological Society of America Bulletin, 95, no. 1, 26-44.

Tissot, B.P., and Welte, D.H., 1978, Petroleum formation and occurrence: New york, Springer-Verlag, $538 \mathrm{p}$.

Vail, P. R., R. M. Mitchum, Jr., R. G. Todd, J. M. Widmier, S. Thompson, III, J. B. Sangree, J. N. Bubb, and W. G. Hatfield, 1977, Seismic stratigraphy and global changes in seal level: in Seismic Stratigraphy-Applications to Hydrocarbon Exploration, p. 49-205, ed. C. E. Payton, AAPG, Tulsa, Memoir 26.

Vine, J.D., 1969, Geology and coal resources of the Cumberland, Hobart, and Maple Valley quadrangles, King County, Washington: U.S. Geological Survey Professional Paper 624, $67 \mathrm{p}$.

Vozoff, Keeva, The magnetotelluric method in the exploration of sedimentary basins, Geophysics, 37, 98-141, 1972.

Walsh, T.J., Korosec, M.A., Phillips, W.M., Logan, R.L., and Schasse, H.W., 1987, Geologic Map of Washington - southwest quadrant: Washington Division of Geology and Earth Resources, Geologic Map GM-34, 28 p., scale 1:250,000.

Walsh, T.J., and Lingley, W.S. Jr., 1991, Coal maturation and the natural gas potential of western and central Washington: Washington Division of Geology and Earth Resources Open-File Report 91-2, 26 p.

Walsh, T. J. and W. M. Phillips, 1983, Rank of Eocene coals in western and central 
Washington State: a reflection of Cascade plutonism: Washington Dept. of Natural Resources, Open-File Report 83-16.

Weaver, C.S., and Smith, S.W., 1983, Regional tectonic and earthquake hazard implications of a crustal fault zone in southwestern Washington: Journal of Geophysical Research, v. 88, p. 10,371-10,383.

Wells, R.E., 1981, Geologic map of the eastern Willapa Hills - Cowlitz, Lewis, Pacific, and Wahkiakum Counties, Washington: U.S. Geological Survey Open-File Report 81 674, scale, 1:62,500.

Wells, R.E., and Rau, W.W., 1983, South flank Willapa Hills, in Armentrout, J.M., Hull, D.A., Beaulieu, J.D., and Rau, W.W., eds., Correlation of Cenozoic stratigraphic units of western Oregon and Washington: Oregon Department of Geology and Mineral Industries Oil and Gas Inestigation 7, p. 51-55.

Wells, R.E., Engebretson, D.C., Snavely, P.D., Jr., and Coe, R.S., 1984, Cenozoic plate motions and the volcano-tectonic evolution of western Oregon and Washington: Tectonics, v. 3, p. 274-294.

Wells, R. E., Engebretsorı, D. C., Snavely, P. D., Jr., and R. S. Coe, 1984, Cenozoic plate motions and the volcano-tectonic evolution of western Oregon and Washington: Tectonics, 3, 275-294.

Willis, Bailey, 1898, Some coal fields of Puget Sound, in U.S. Geological Survey, 18th Annual Report, part 3-C, p. 393-436.

Wolfe, J. A., 1978, A paleobotanical interpretation of Tertiary climates in the northern hemisphere: American Scientist, v. 66, p. 694-703.

Yorath, C. J., 1987, Petroleum geology of the Canadian Pacific continental margin: in Geology and Resource Potential of the Continental Margin of Western North America and Adjacent Ocean Basins-Beaufort Sea to Baja California, eds., D. W. Scholl, Arthur Grantz, and J. G. Vedder, Circum-Pacific Council for Energy and Mineral Resources Earth Science Series, v. 6, p. 283-304.

Zilman, F. N., 1993, U. S. Department of Energy Morgantown Energy Technology Center Deep Seismic Reflection Studies in the Pacific Northwest U.S.: U.S. Geological Survey Open File Rept. 92-714.

Zoback, M. D. and C. M. Wentworth, 1986, Crustal tudies in central California using and 800-channel reflection recording system: in eds. Brazangi, Muawia and Brown, Larry, Reflection Seismology: A Global Perspective, 183-196. 


\section{Appendix A}

Detailed Stratigraphic Data for Surface Sections and Wells

The following sections contains detailed stratigraphic information from measured sectins at locations indicated in Figures 4 and 29. An explanation for the patterns on the section is shown in Figure A1.

Figure Al-Explanation for pattern symbols on measured sections in following illustrations.

AMOCO WC-83-5 stratigraphic section

Figure A2-Index map with locations of AYOCO WC-83-5 well and

"Mineral" measured section.

The AMOCO WC-83-5 borehole site (Fig. A2) is located in SW 1/4. sec. 29, T. 14 N., R. 5 E. (Mineral 7.5' U.S.G.S. topographic quadrangle). The measured section (Fig. A3) is based on description of nearly continuous core, collected in the borehole from a depth of $156.1 \mathrm{~m}$ to the total depth of $608.7 \mathrm{~m}(1,996.5 \mathrm{ft})$. The lowest $25.2 \mathrm{~m}(82.6 \mathrm{ft})$ of core consists of medium-grained intrusive rock and the mean

Figure A3-Core section description for AYOCO WC-83-5 well.

structural dip in cored strata is about $20^{\circ}$ thus the section thickness $(\sim 401 \mathrm{~m})$ is smaller than the total length of the core. The core included three intervals ( $\sim 47$ percent of the core) interpreted as shallow- to marginal-marine deposits, and two intervals $1 \sim 53$ percent of the core) interpreted as nonmarine deposits. Vitrinite reflectance was analyzed for four samples. 
Explanation for measured sections

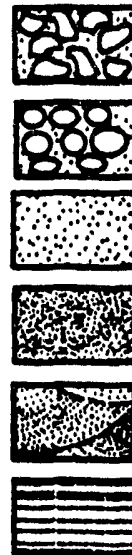

breccia-conglomerate

conglomerate

massive arkosic sandstone, siltstone

massive volcano-lithic sandstone, siltstone

crossbedded sandstone

horizontal to low-angle bedded sandstone

sandstone with mudstone partings

mudstone with sandstone partings

laminated siltstone, mudstone

carbonaceous shale

coal

volcanic tuff or flow

$\because \because \vdots$ igneous intrusion

T ripple mark and

mo $\prod_{m} c \infty$

$8 s$

grain size

ma - mudstone

$v$ - very fine grained sandstone

m - medium-grained sandstone

c - coarse-grained sandstone

col - conglomerate

$\rightarrow$ paleocurrent indicator

fault

$\sim$ scour surface

$\mathrm{nm}$ - mainly nonmarine depositional environment

msm - mainly marginal or shallow marine depositional environment 


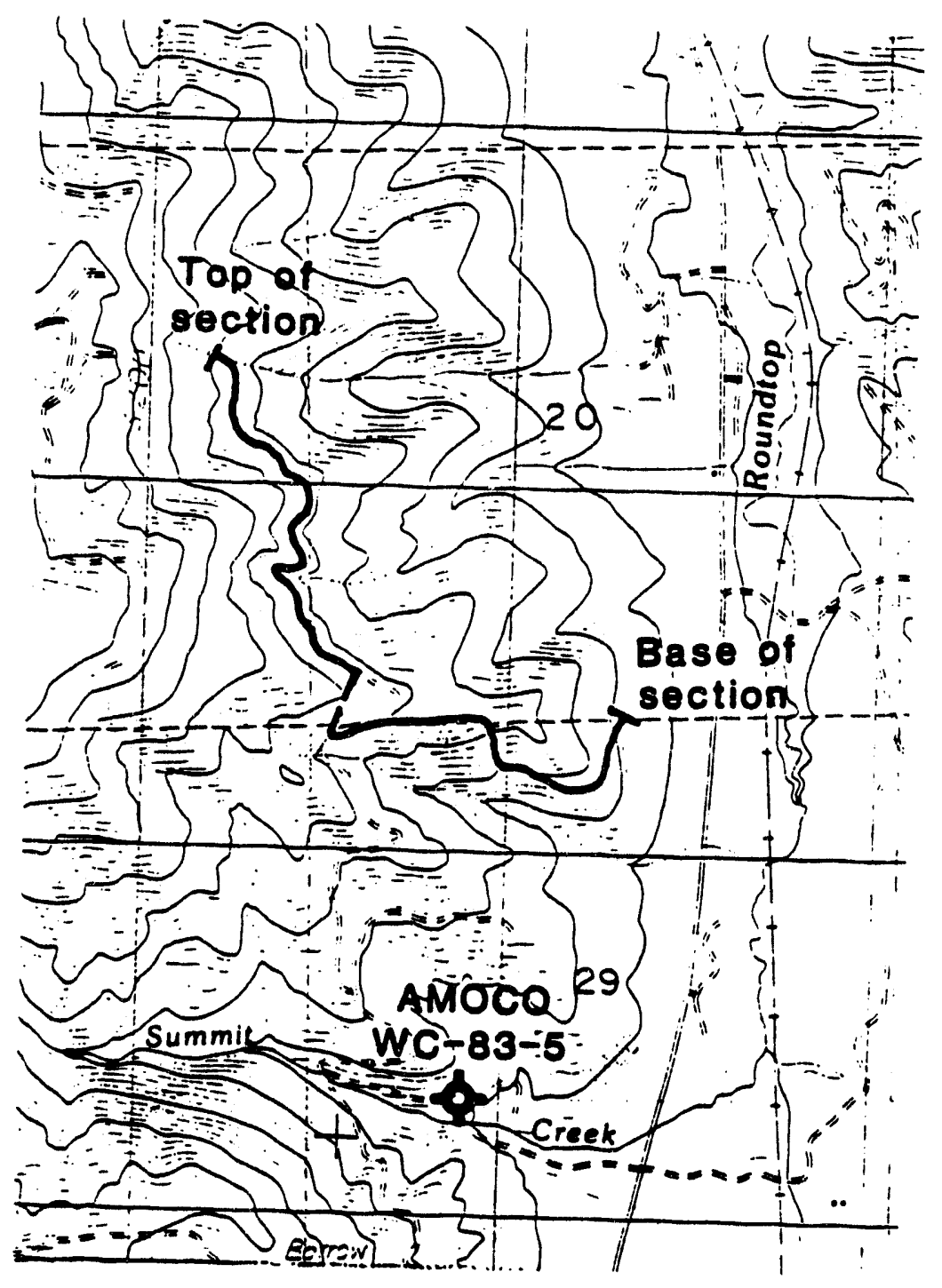

Figure A2 
$\varepsilon \forall \operatorname{\theta sn} B ! J$

ss

100 0 u A pur $\begin{aligned} & \text { nem } \\ & L 1\end{aligned}$

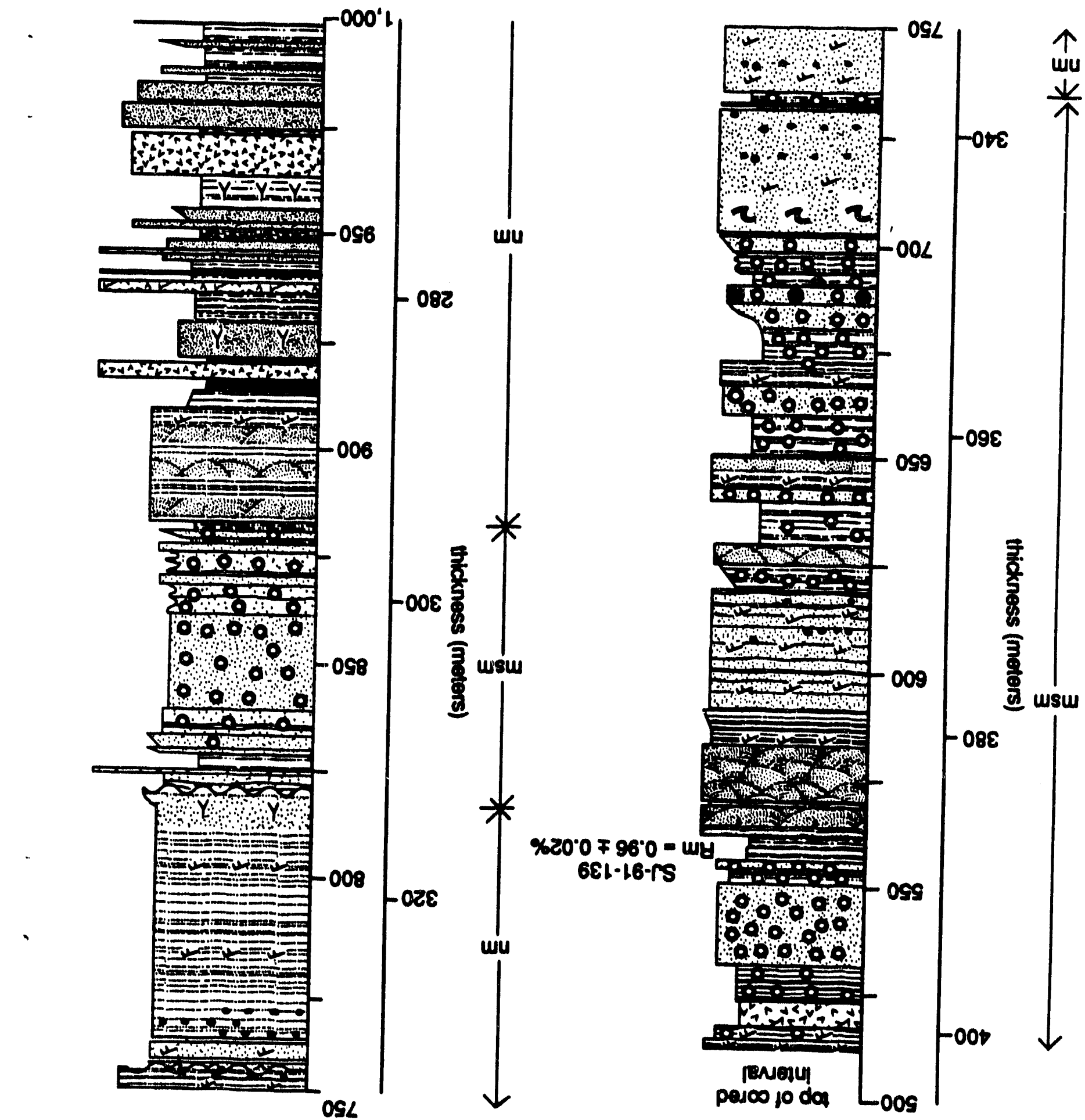

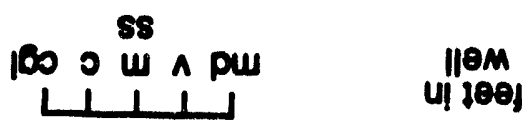




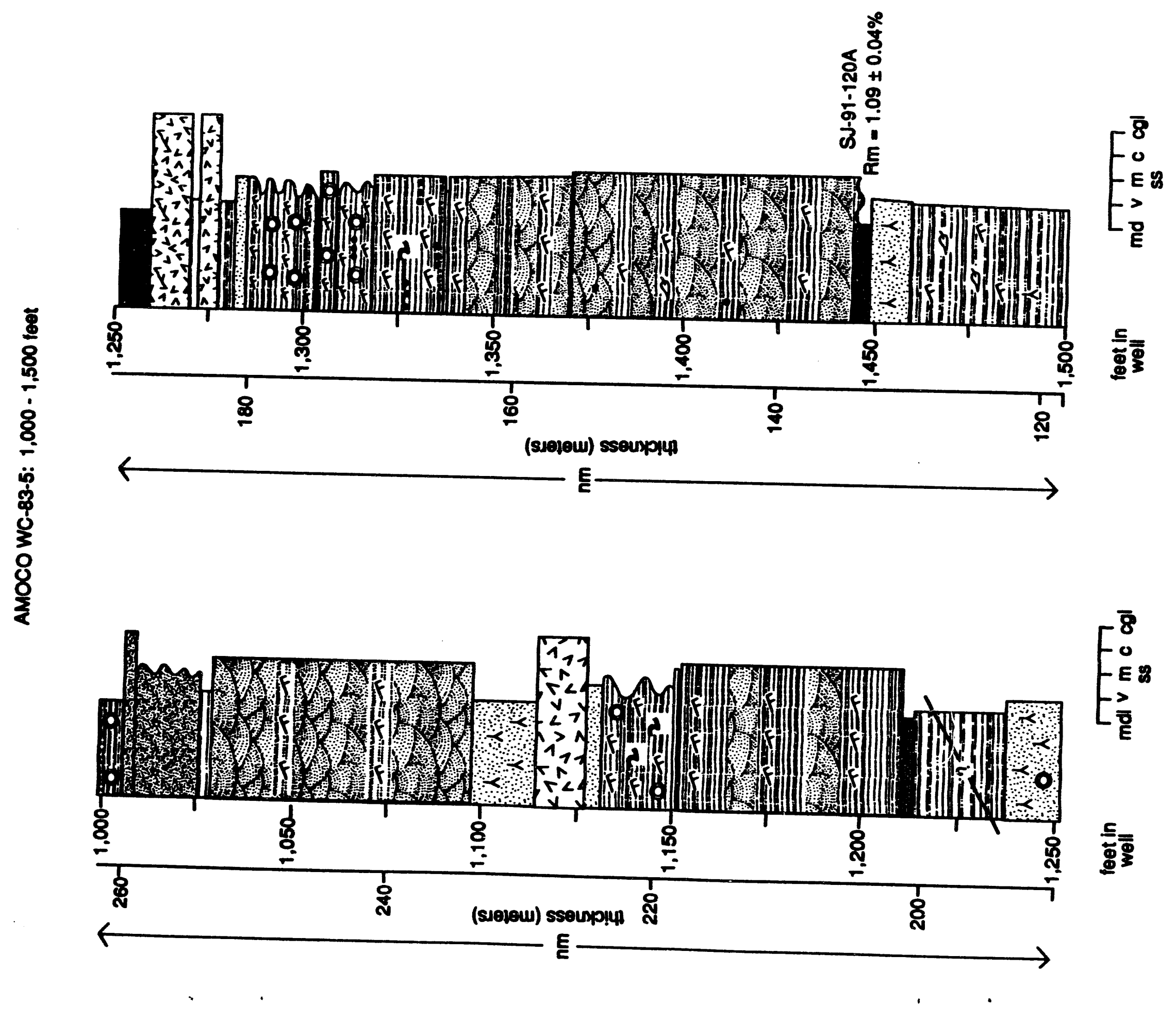



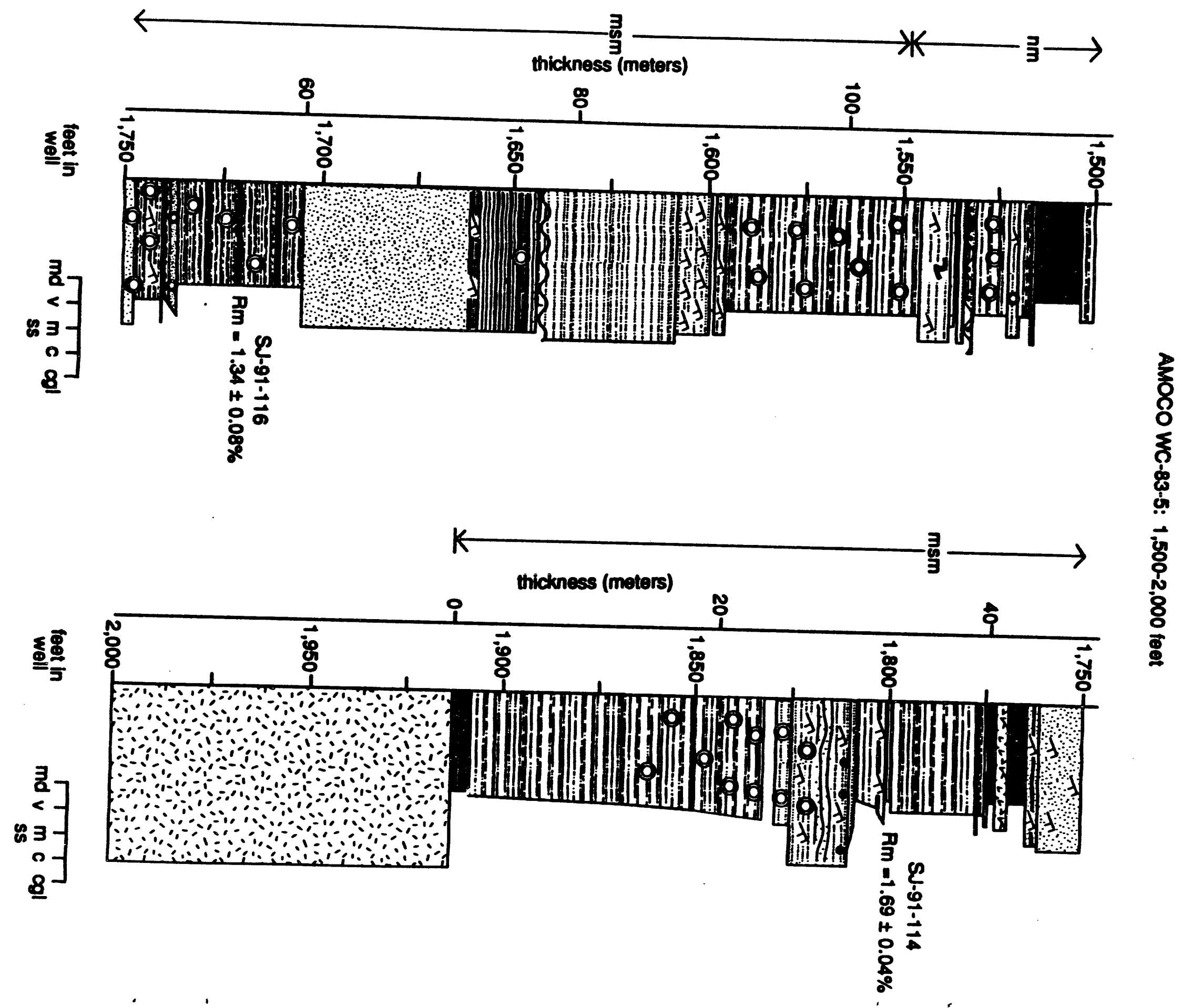
Table AI- Vitrinite Reflectance data for AxOCO wC-83-5 well. 
File Name: SJ-91114

Channol Name: SJ-91-114

Description: core, coal, good sample

Comment 1:

Comment 2:

Comment 3:

Comment 4:

Comment 5:

Comment 6:

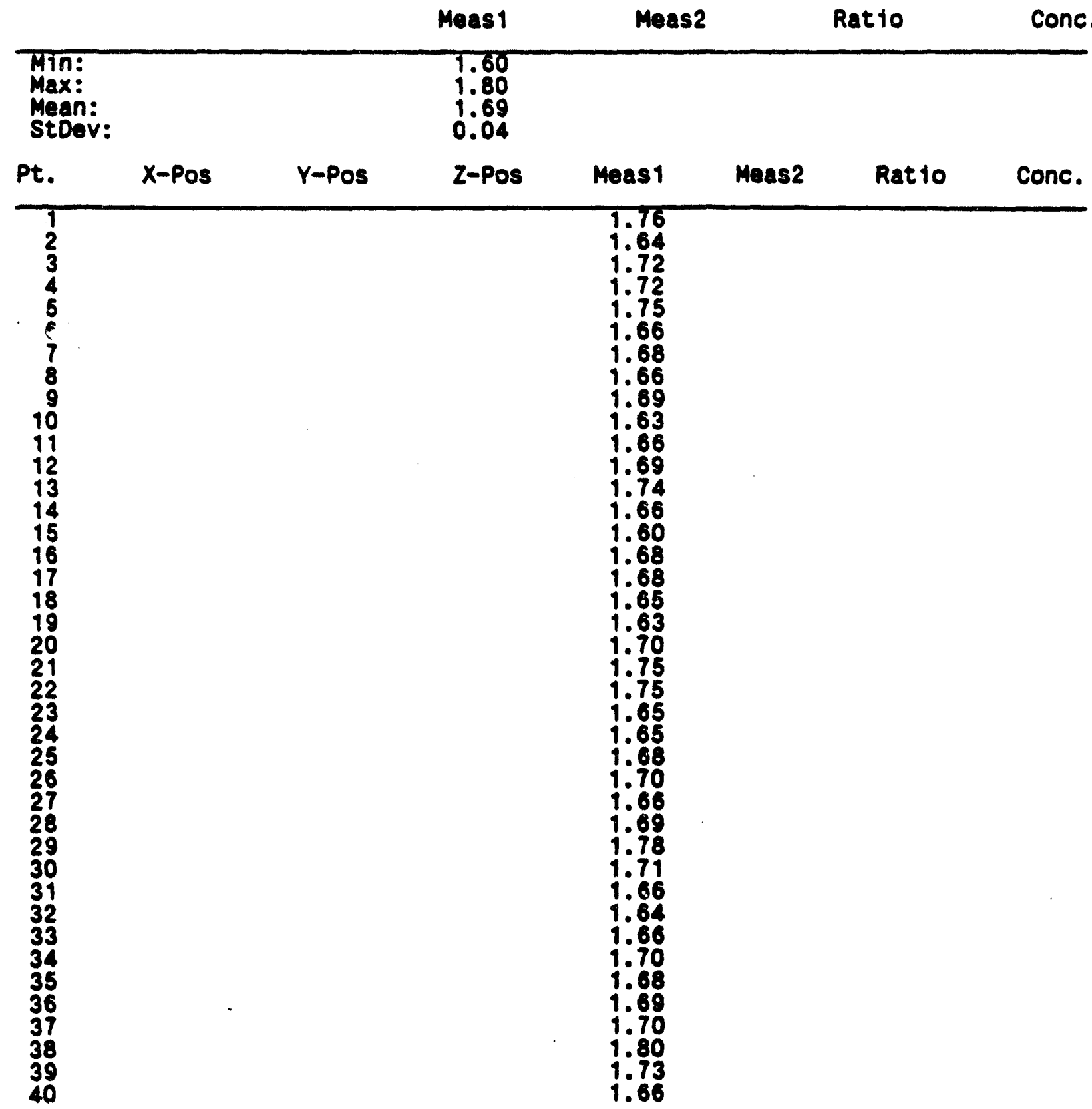




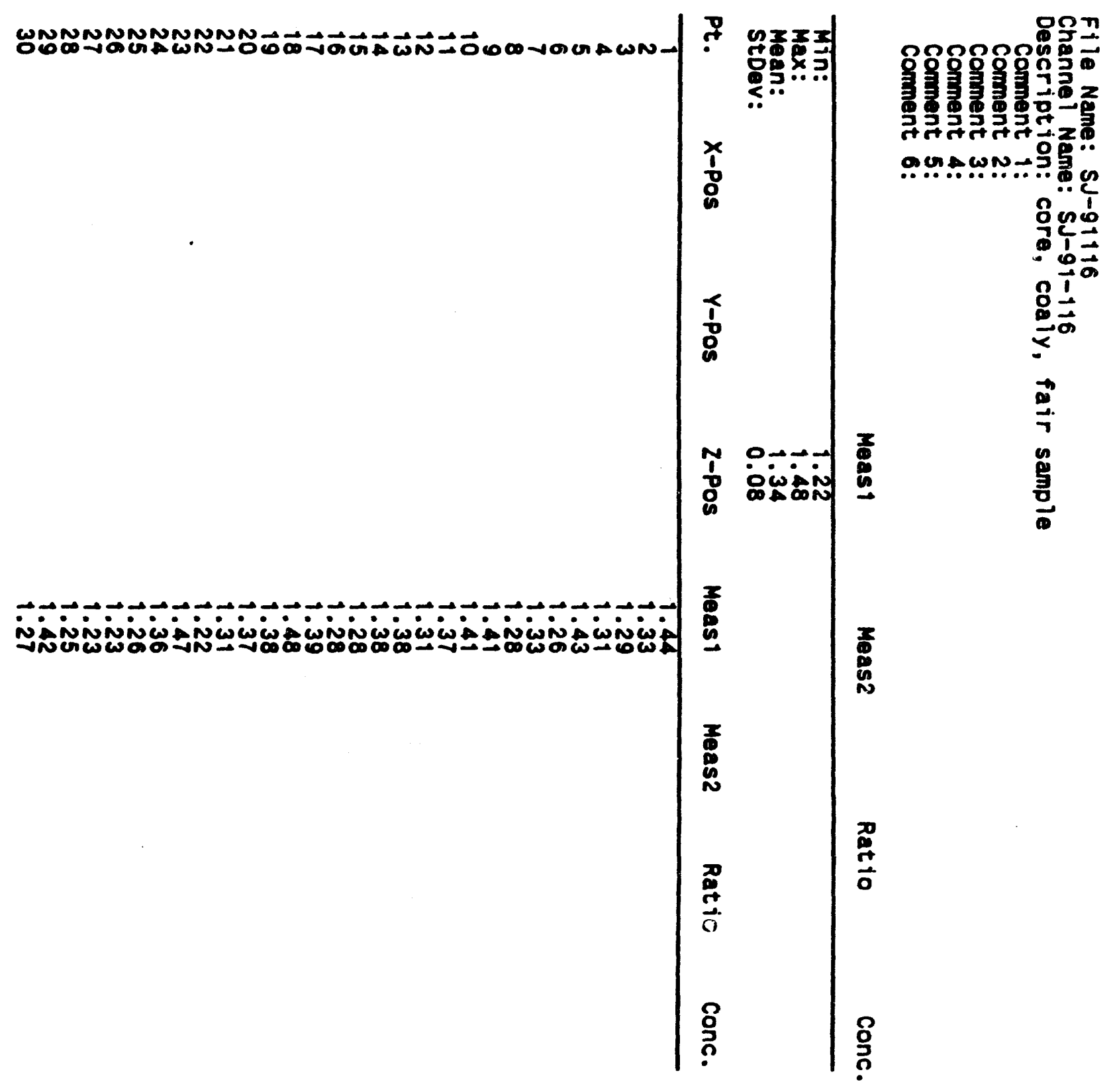




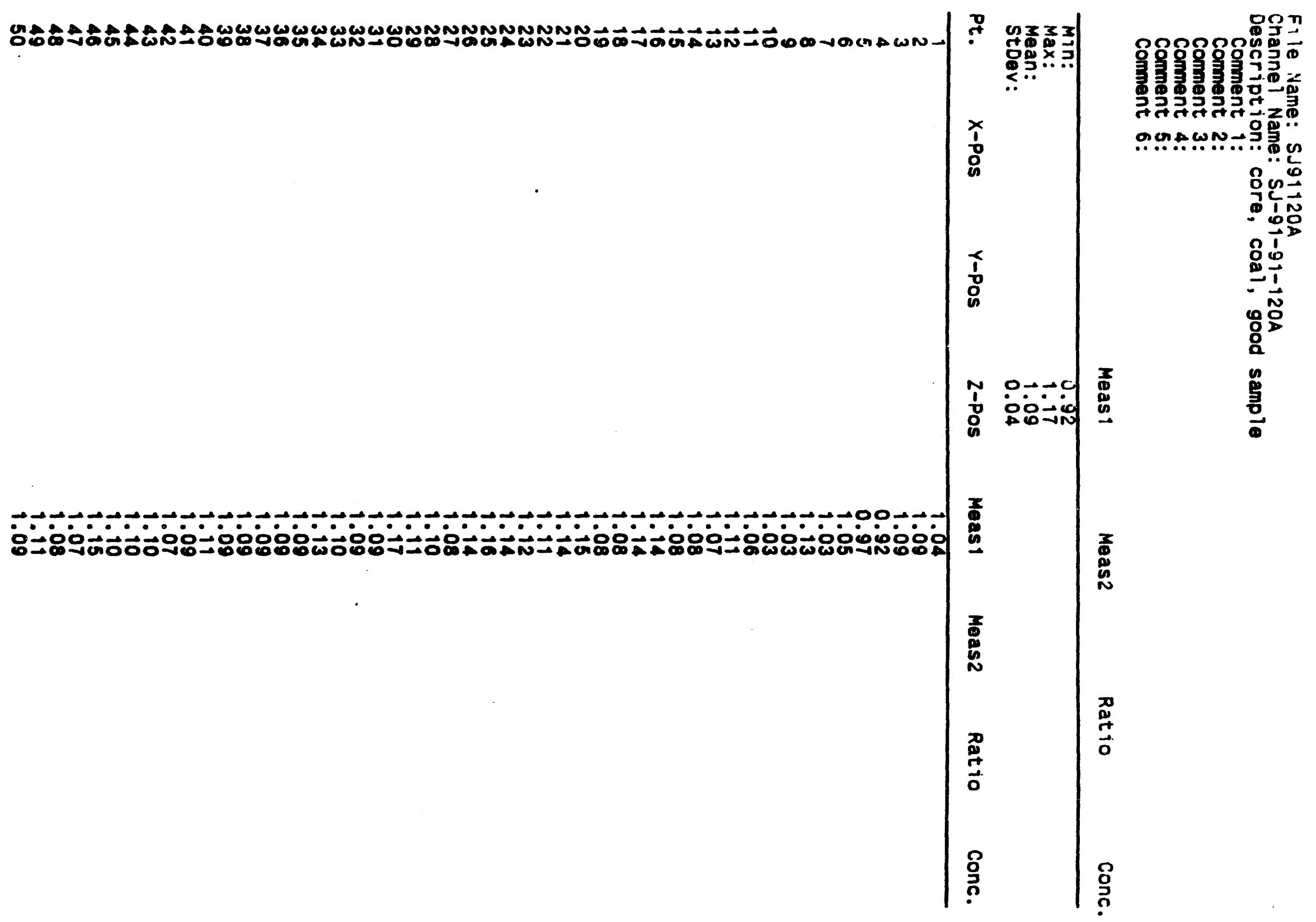


File Nane: SJ91-139

Channel Name: SJ-91-139

Comment 1: core, coal, good sample

Comment

Comment 3:

Comment 4:

Comment 5:

Comment 6:

$\begin{array}{lcccc} & \text { Meas1 } & \text { Meas2 } & \text { Ratio } & \text { Conc. } \\ \text { Min: } & 0.90 & & \\ \text { Max: } & 1.00 & & \\ \text { StDev: } & 0.96 & & \\ \text { Pt. } & 0.02 & & \end{array}$

Pt. $X$-Pos $Y$-Pos

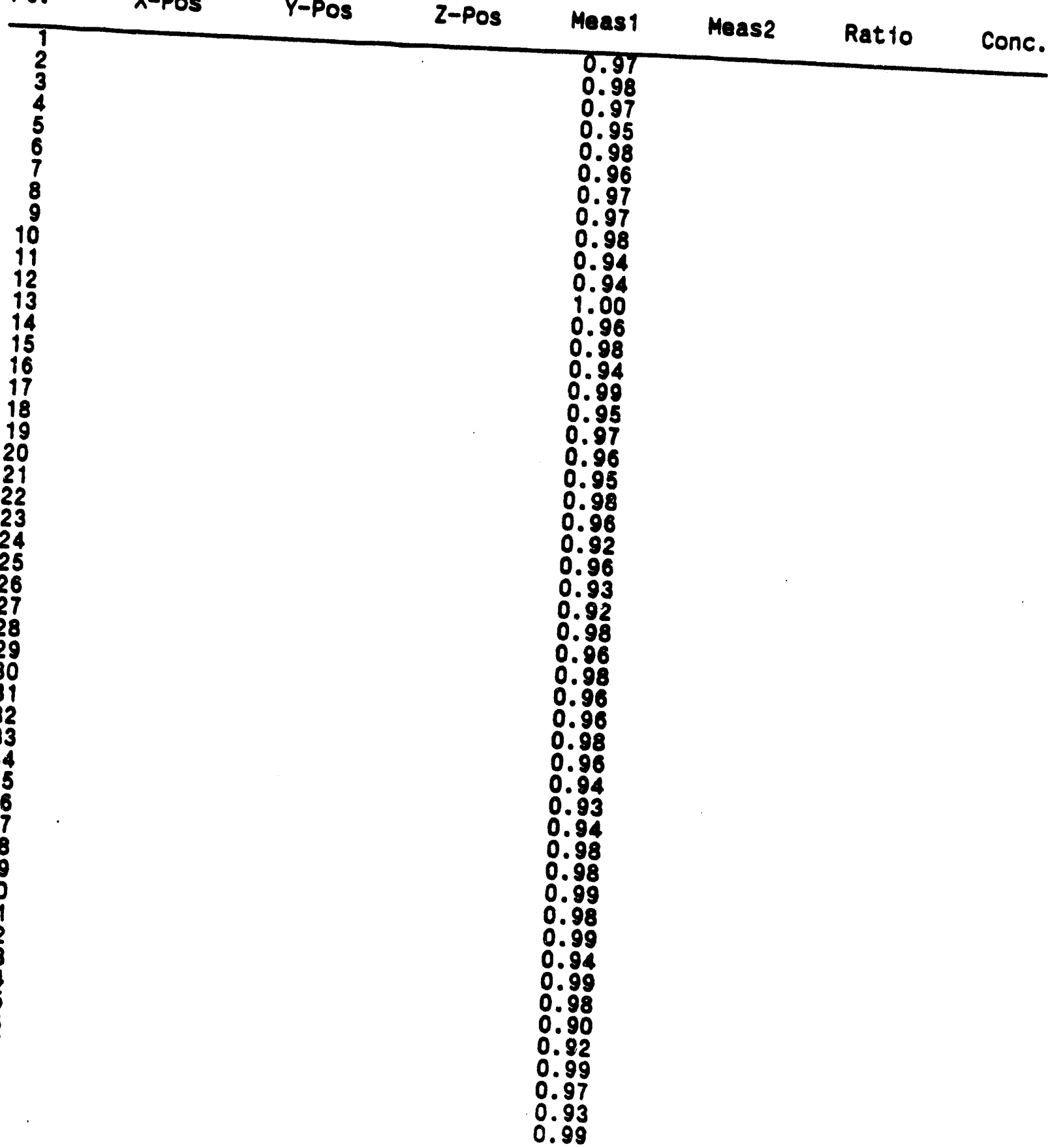


Mineral stratigraphic section

The Mineral stratigraphic section (location on Fig. A4) of the Carbonado Formation was measured in NE 1/4, NW 1/4, sec. 29; SW 1/4 sec. 20; and SE 1/4, NE 1/4, sec. 19, T. 14 N., R. 5 E. (Mineral 7.5' U.S.G.S. topographic quadrangle), on the western

Figure A4-Location of wuineral" stratigraphic section.

slopes of the valley between the towns of Morton and Mineral. The base of this section (Fig. A5) is located approximately 1,000 m north-northeast of the AMOCO WC-83-5 borehole. The section is approximately $494 \mathrm{~m}$ thick (Fig. A4). The lower $80 \mathrm{~m}$ of the section is exposed in cuts on logging roads low on the valley flank. This lowest part of the section was pieced together from several discontinuous outcrops

Figure A5-Measured section along "Mineral" profile, location in Fig. A4).

of variable quality with relatively similar structural dips. These outcrops are cut by several faults, however, which might have disrupted primary stratigraphic order. The portion of the measured section between $80 \mathrm{~m}$ and $131 \mathrm{~m}$ is mostly covered and corresponds to recently logged terrain above the lower road. The upper part of the section (130 to $494 \mathrm{~m}$ ) was measured in nearly continuous, excellent exposures along a north-trending log road higher on the valley flank.

At the top of the Mineral measured section, sedimentary rocks with an increasingly large component of volcanic and volcaniclastic rocks are overlain by massive volcanic rocks. Schasse (1987) included these volcanic rocks as one of several volcanic interbeds within the Puget Group (Carbonado Formation), well below the contact with the volcanic Northcraft Formation. Based on reconnaissance surveys, my observation is that the rocks above the top of the Mineral measured section and below the mapped contact with the Northcraft Formation are predominantly volcanic in origin. Hence, I would place the contact between the Carbonado Formation and the Northcraft Formation at the top of the Mineral section.

Nonmarine deposition is interpreted for three thick intervals comprising about 91 percent of the measured section; shallow- to marginal-marine deposition is inferred for two thin intervals comprising about 9 percent of the section. Vitrinite reflectance was analyzed for three samples. 


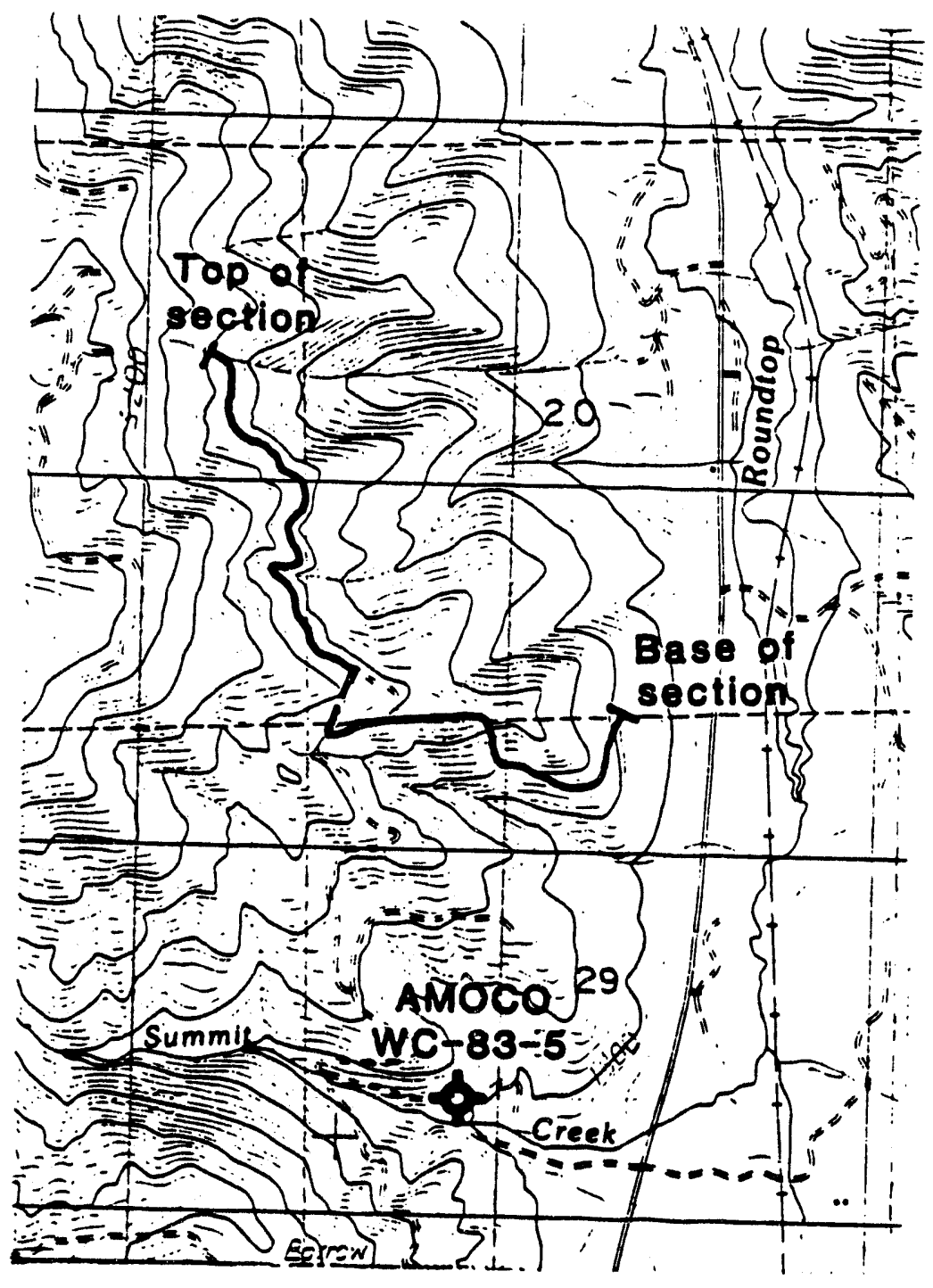

Figure $\mathrm{A}_{4}$ 

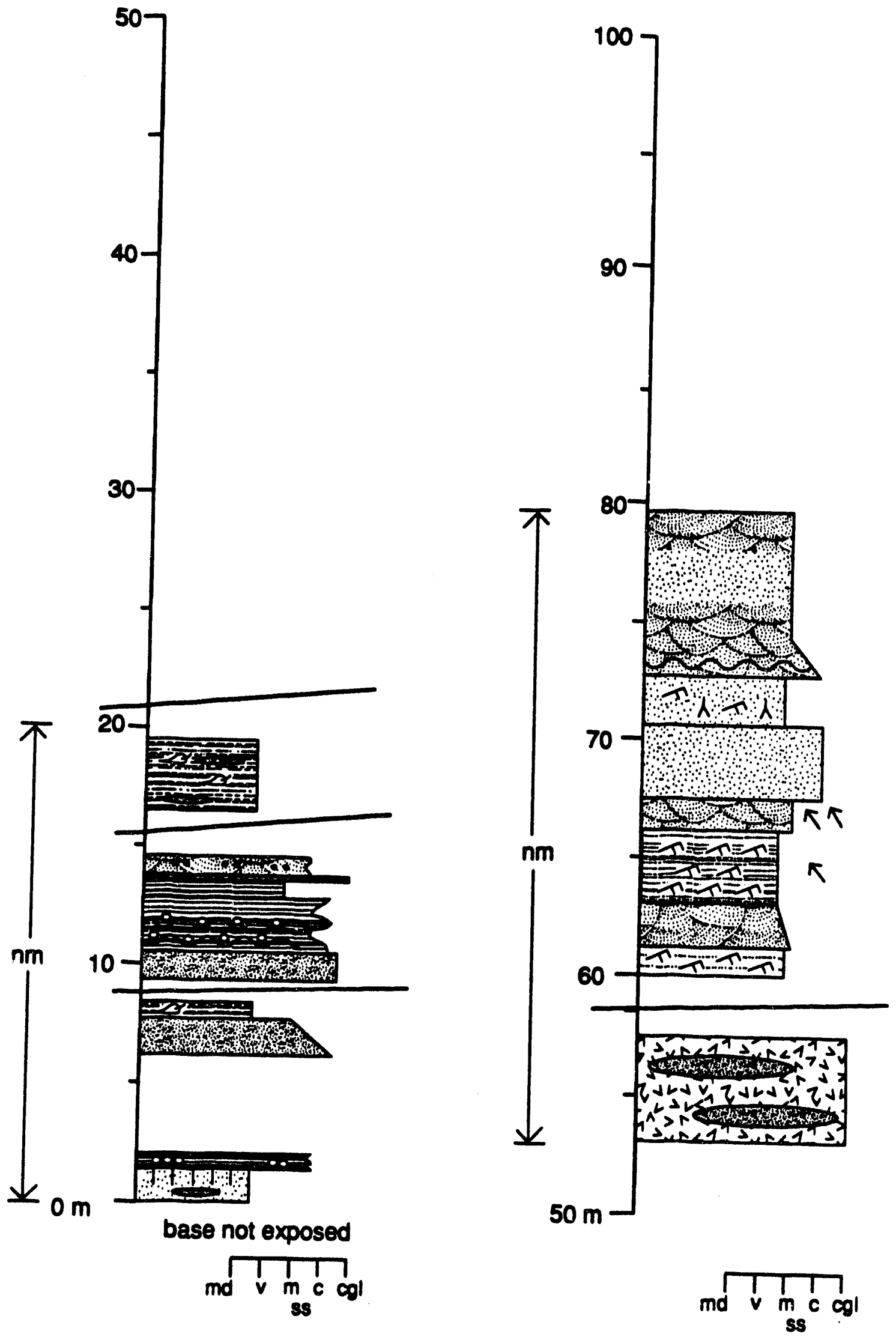

Figure A5 


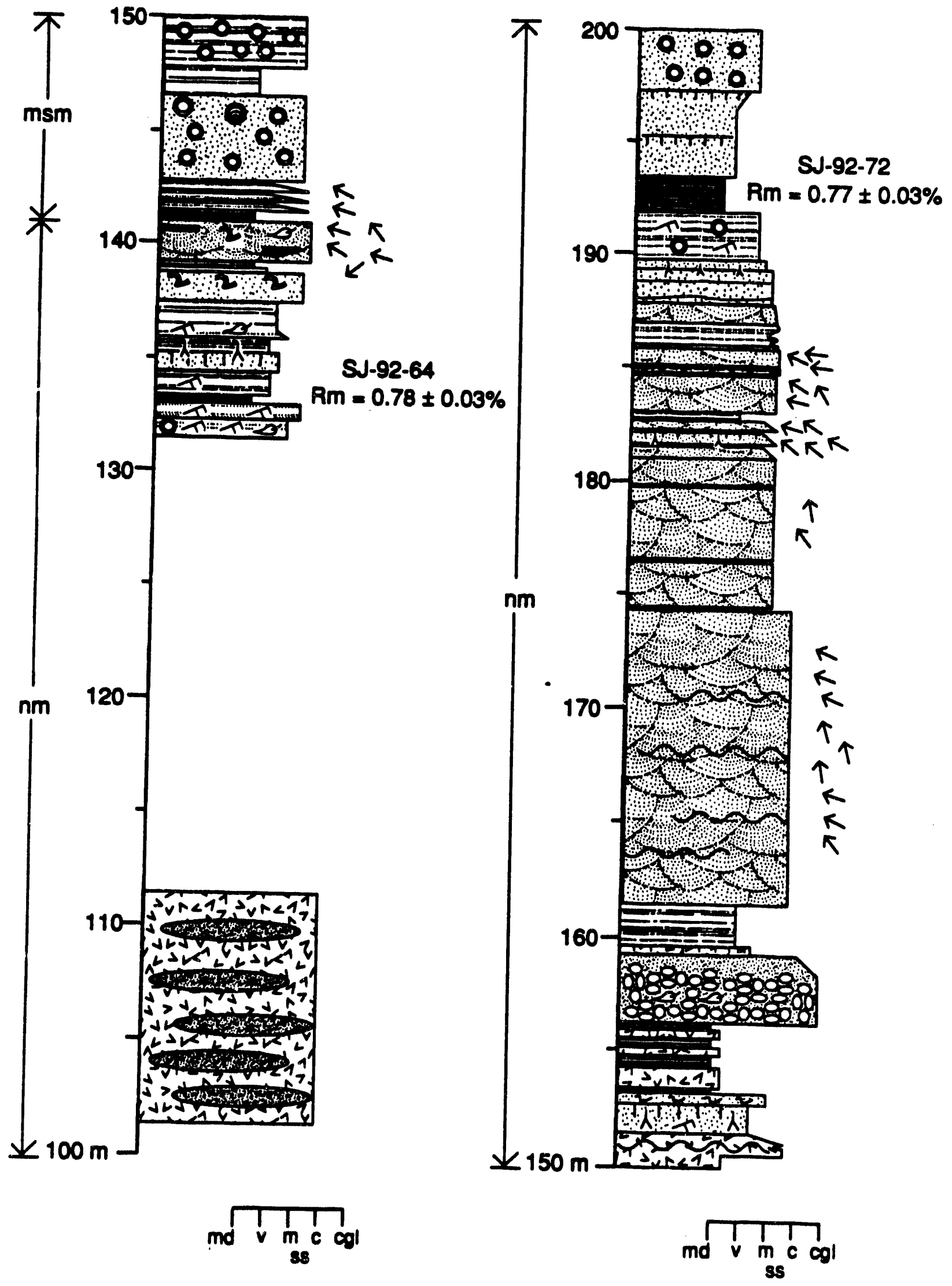



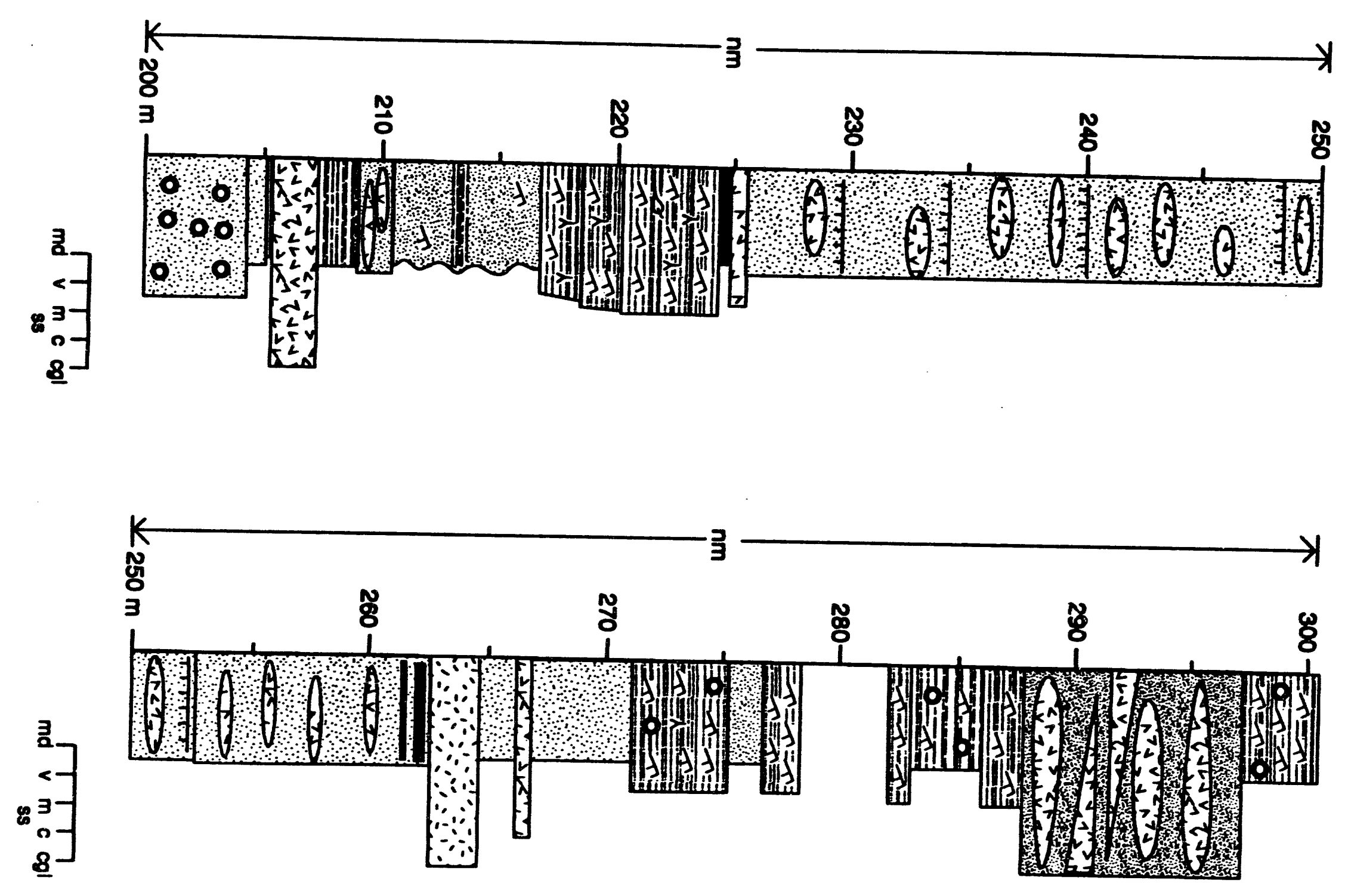

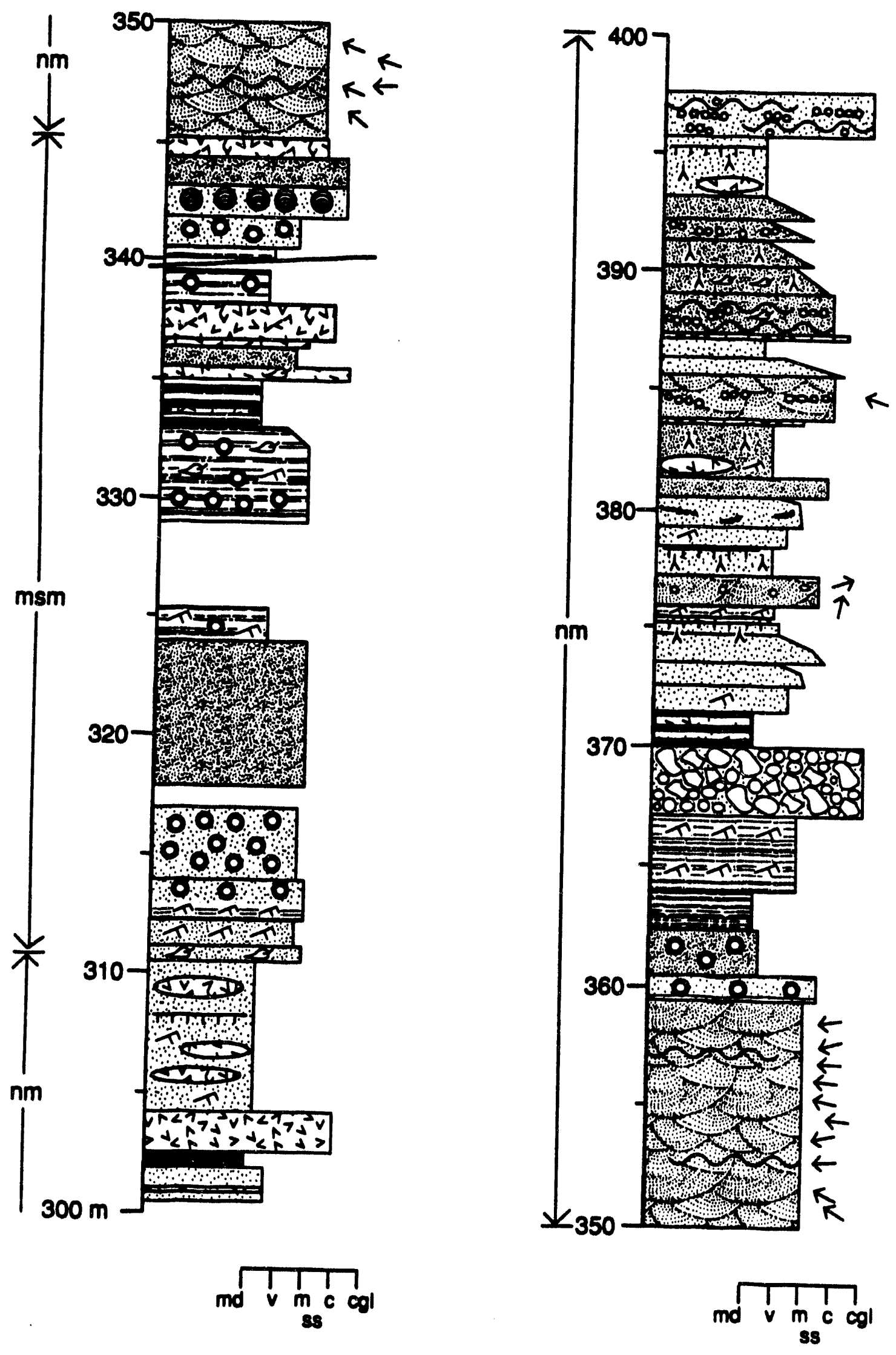


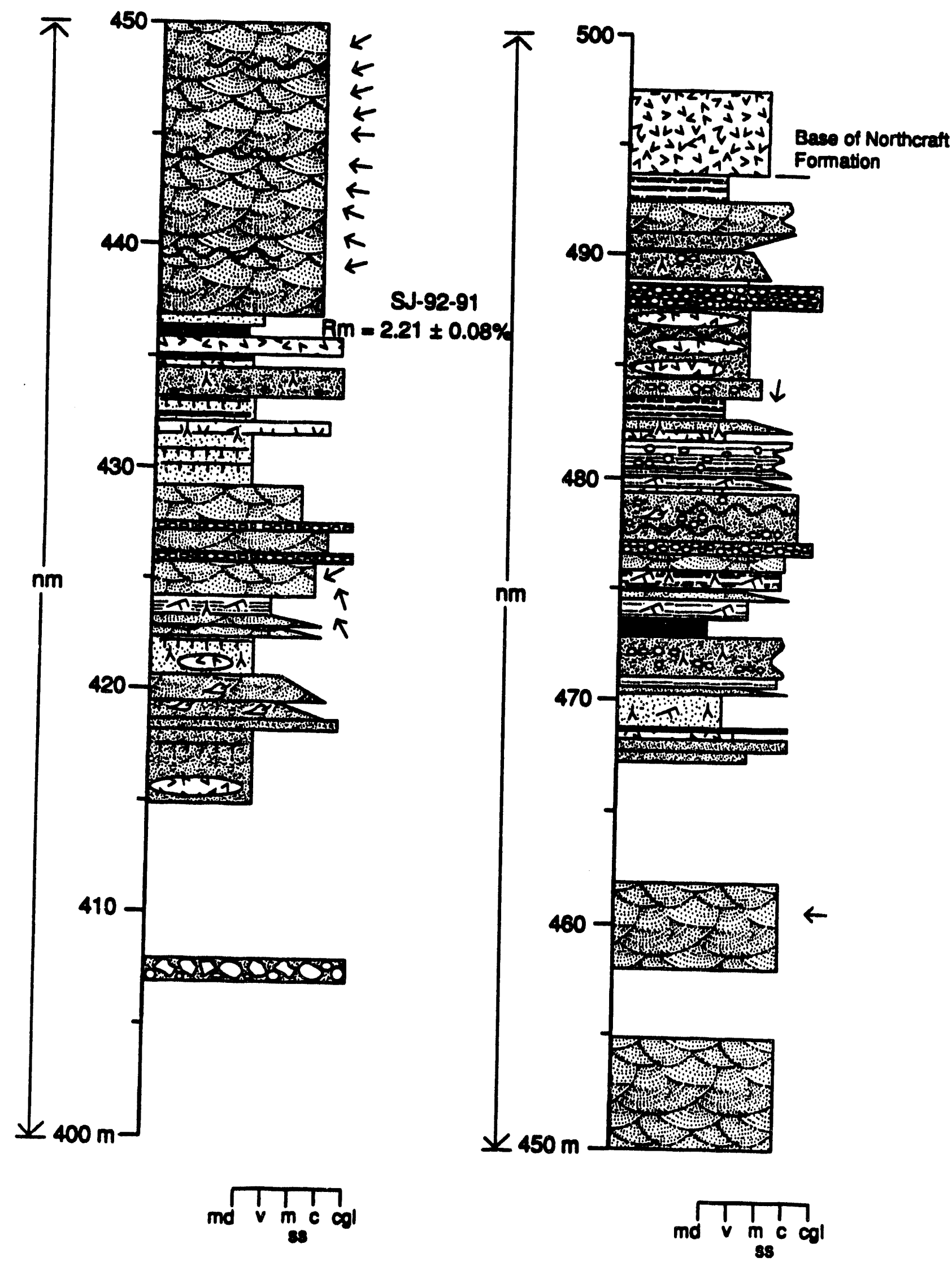


Table A2-vitrinite reflectance data for Mineral stratigraphic section. 


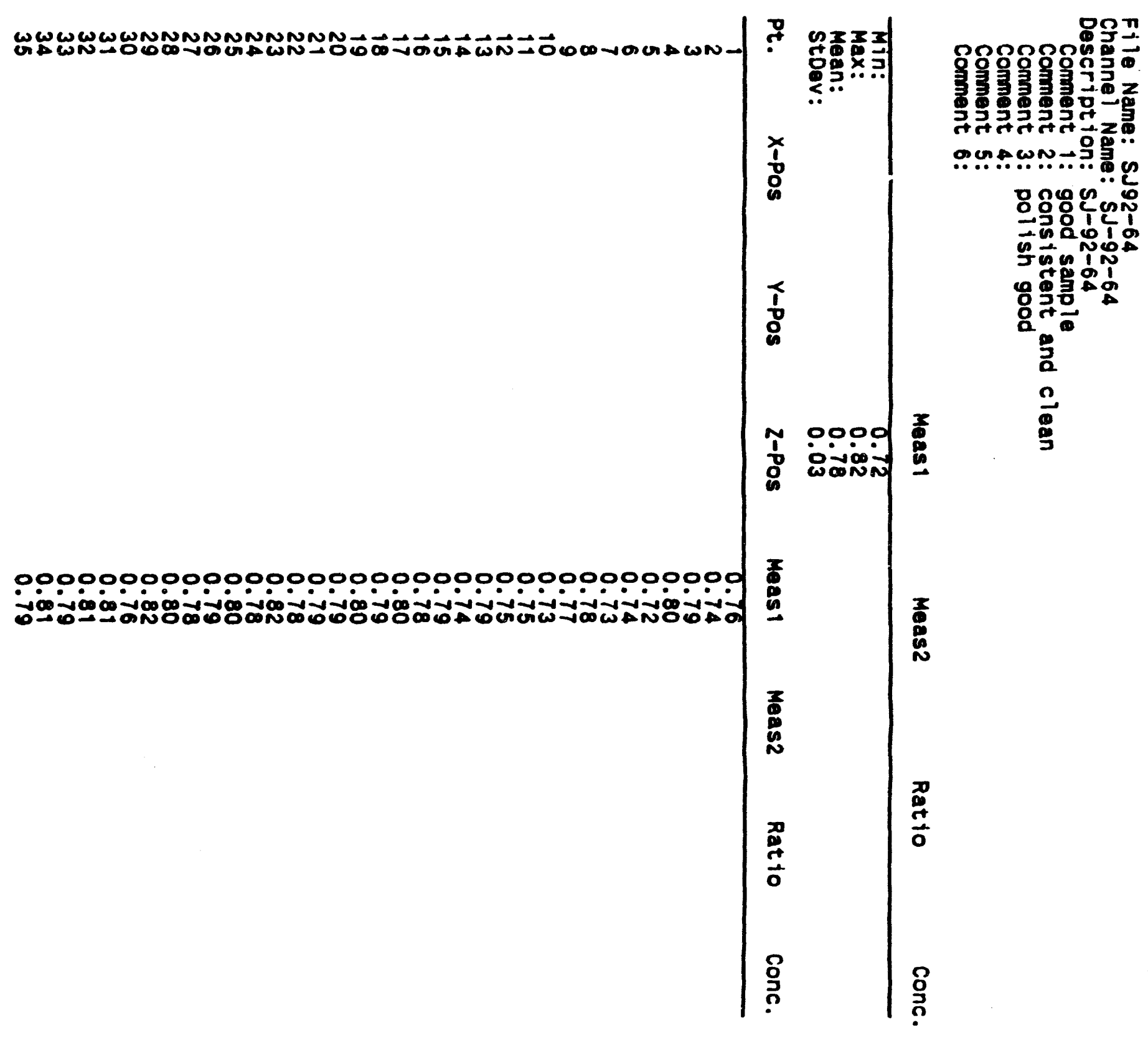




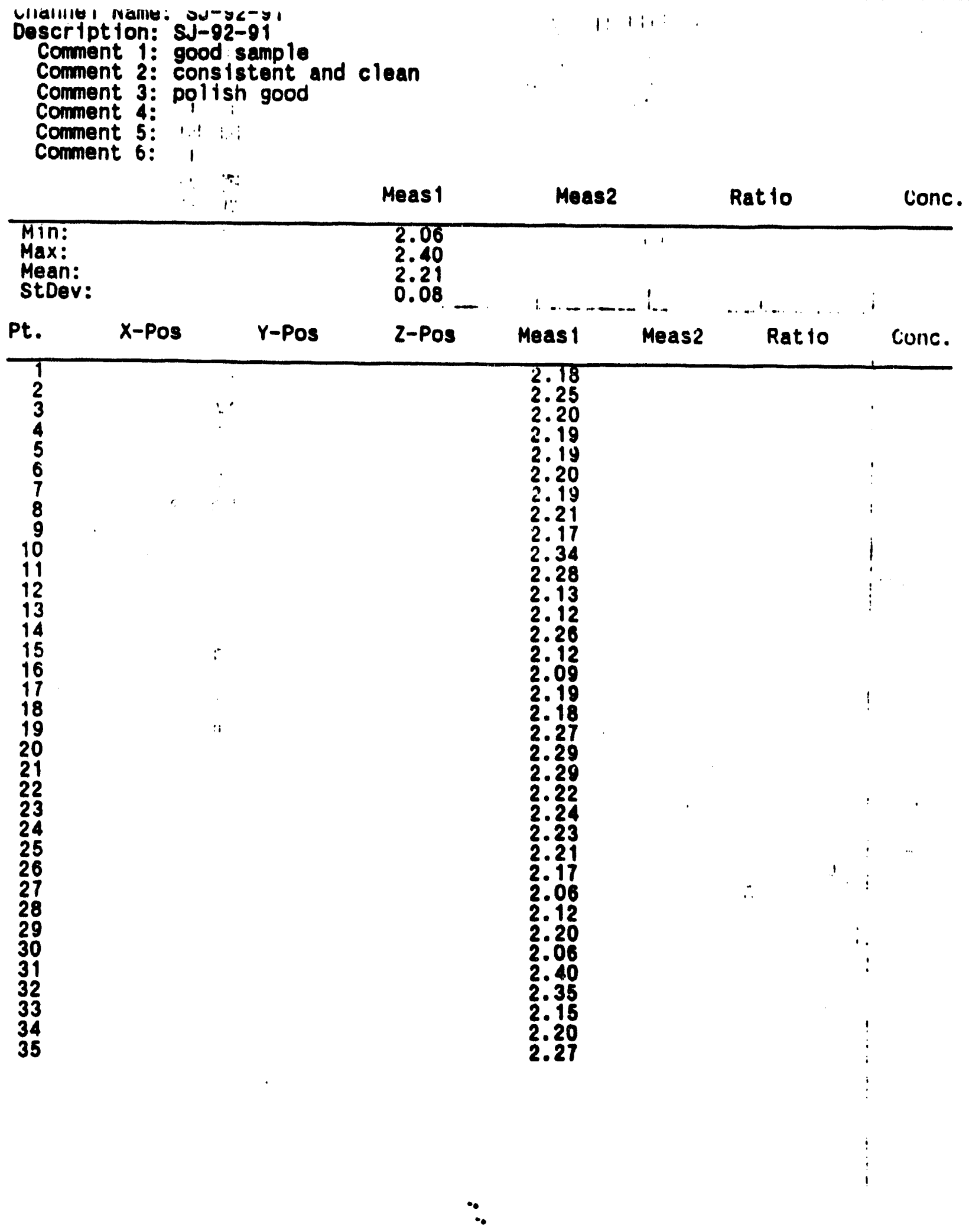


Fi ie Name: $5 j-9:-72$

Gonne i vame: Sj- $:-: 2$

Jes:-icion: $z_{0}-3-\cdots$

ominen: 1: joce s am $=$ ڤ

Commer: 3: clean, consiszent vitrinite

Comment 3 :

Comment 4:

Comment 5:

Comment 5 :

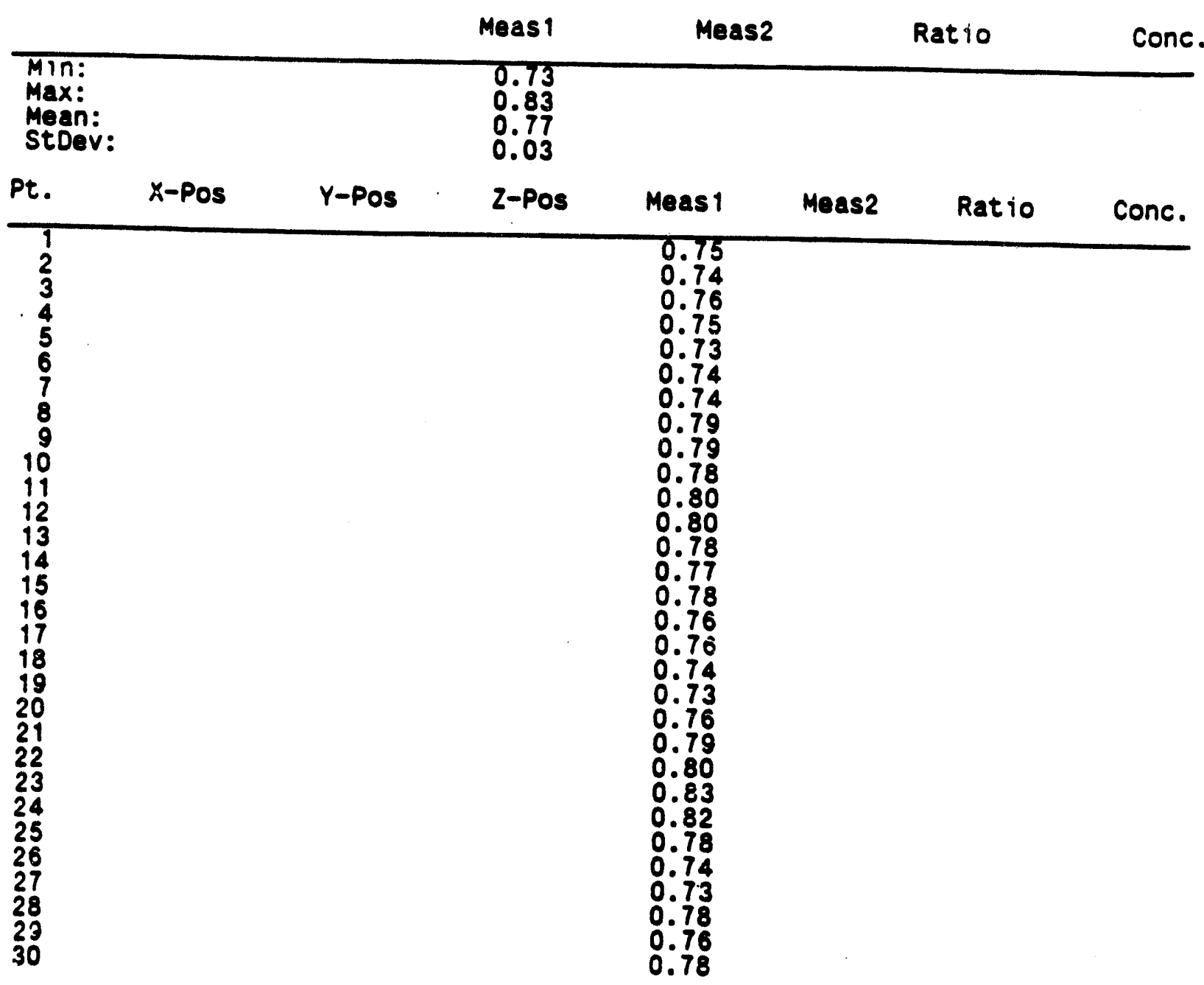


Bergen Mountain stratigraphic section

The Bergen Mountain stratigraphic section (Fig. A6) of the Carbonado Formation was measured in SW 1/4, sec. 9; SE 1/4, sec. 8; and NE 1/4, sec. 17, T. 13 N., R.

Figure 16-Location of Bergen Mountain stratigraphic section.

4 E. (Morton 7.5' U.S.G.S. topographic quadrangle). The section is $424 \mathrm{~m}$ thick and was measured in cuts on a logging road about 700 to $1,700 \mathrm{~m}$ northeast of Bergen Mountain. The measured section includes significant cover (about 23 percent) but only a few small faults were recognized and it is inferred to be stratigraphically intact. The base of the section corresponds to the first good outcrops along the road. At the top of the section (Fig. A7), the highest Carbonado strata are cut by a mediumgrained, andesitic dike or sill. Based on bedding-plane attitudes in underlying and

Figure A7-Yeasured section at Bergen yountain location.

overlying rocks, this intrusive body is about $\mathbf{4 6} \mathrm{m}$ thick. Rocks exposed above the intrusion include volcanic flows, tuffs, and associated intrusions assigned to the Northcraft Formation.

The lower $168 \mathrm{~m}$ of the section consists of three (7 to $24 \mathrm{~m}$ thick) intervals of inferred nonmarine origin and four intervals (5 to $63 \mathrm{~m}$ thick) of inferred shallow- to marginal-marine origin. The upper $256 \mathrm{~m}$ of the section has an inferred nonmarine origin. Overall, the section is inferred to include about 70 percent nonmarine strata and 30 percent shallow to marginal marine strata. Vitrinite reflectance was analyzed for four samples. 


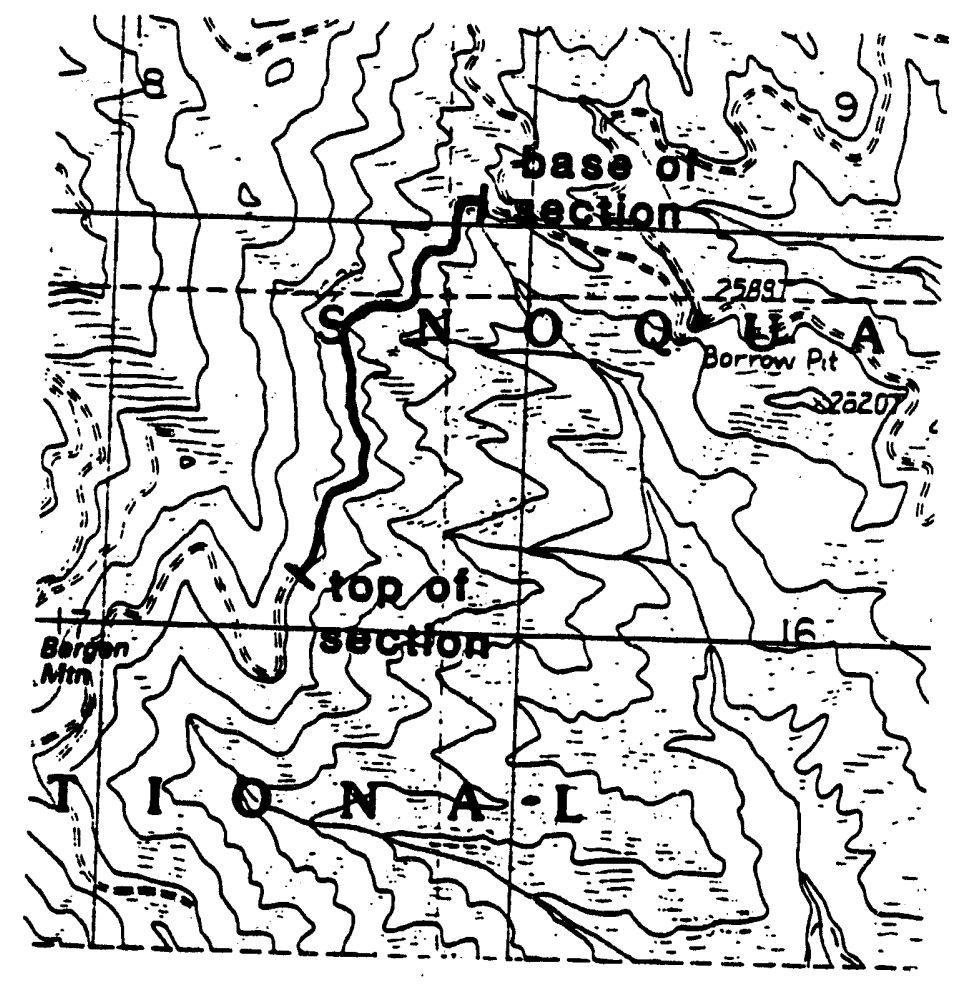

Figure A 6 

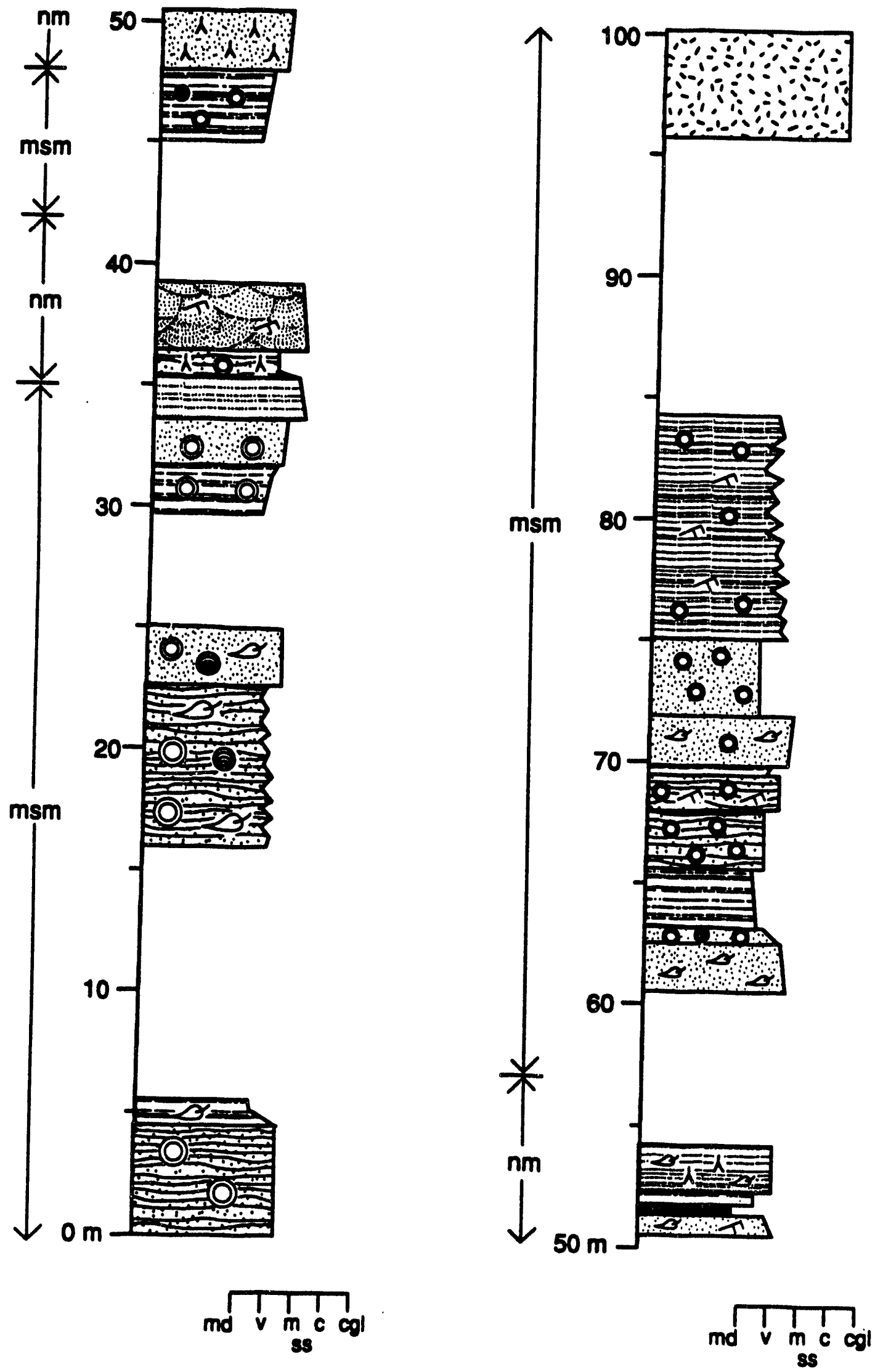

Figure AT 


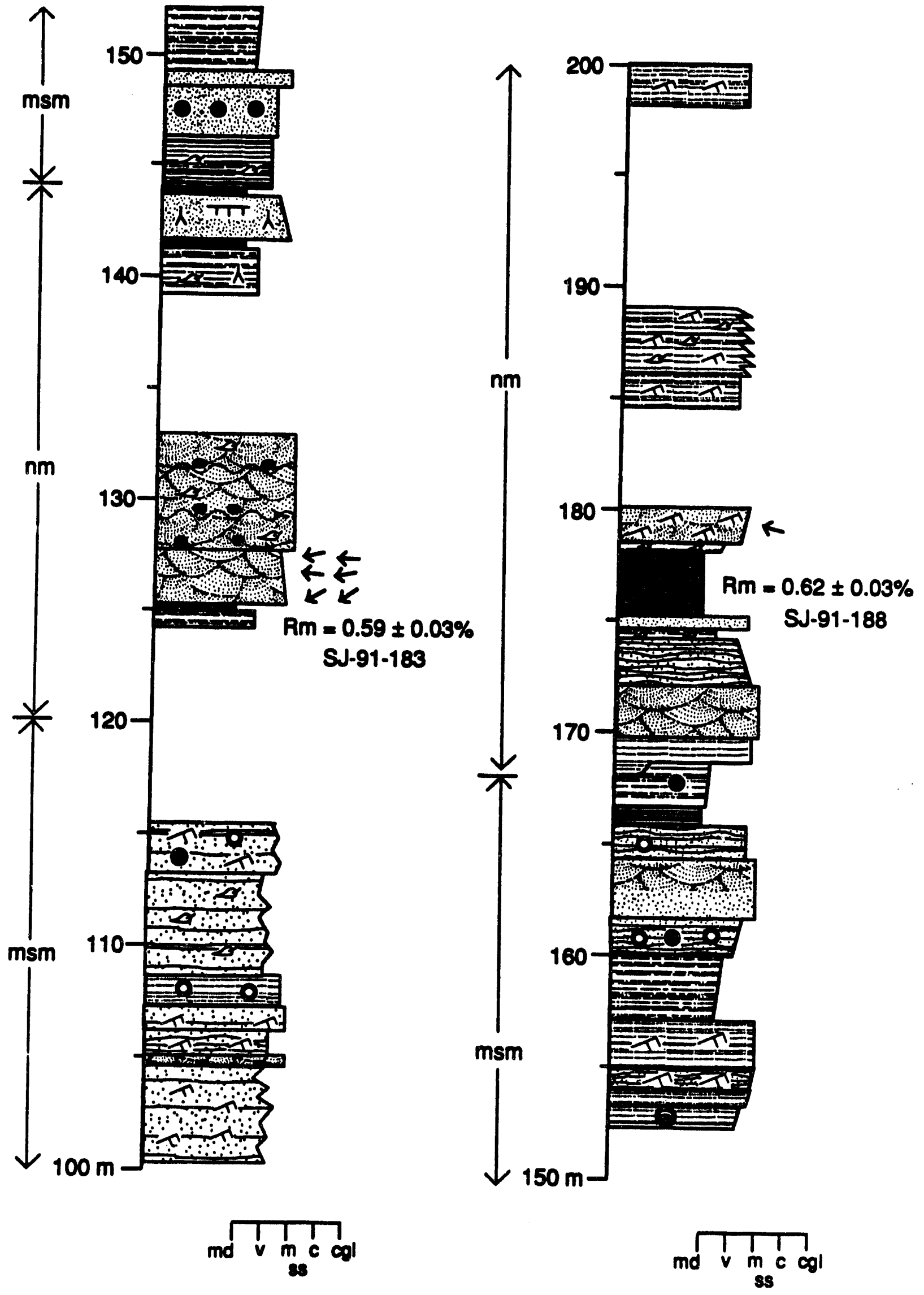



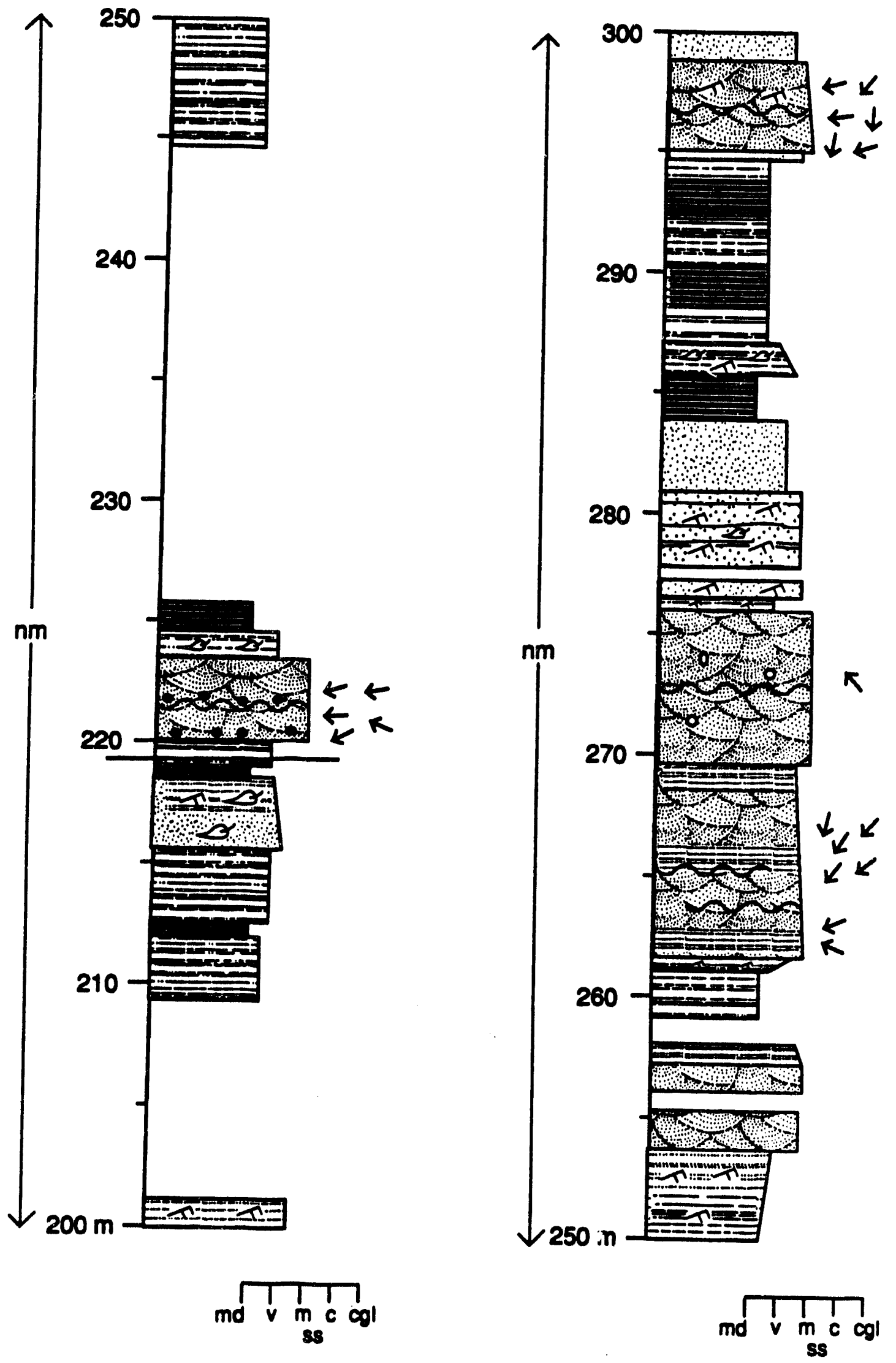


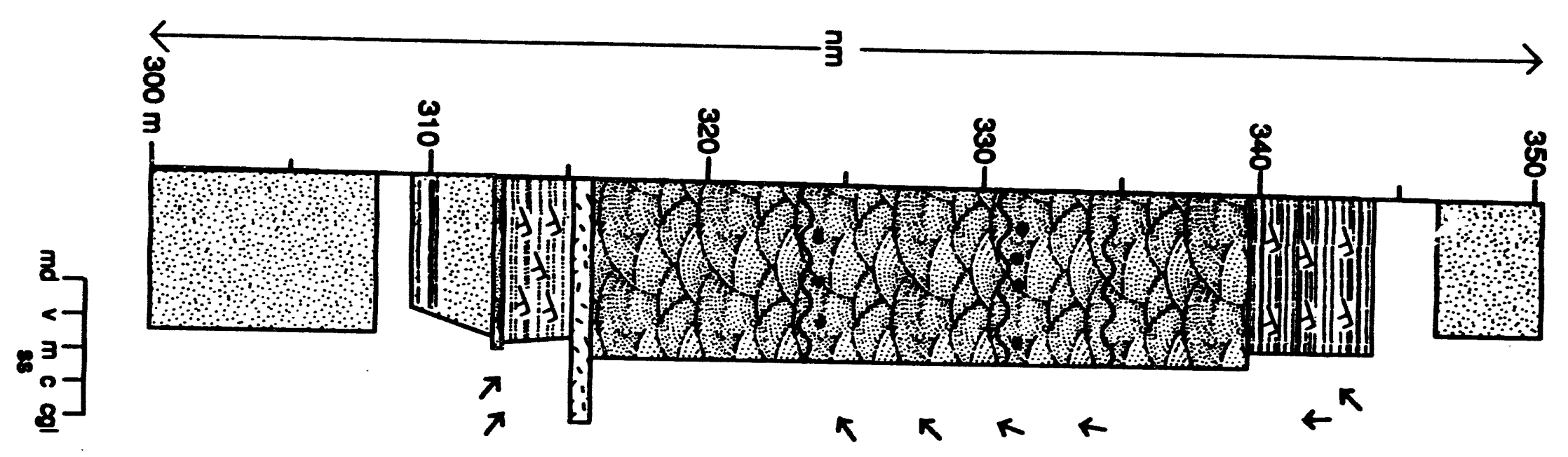

蓑

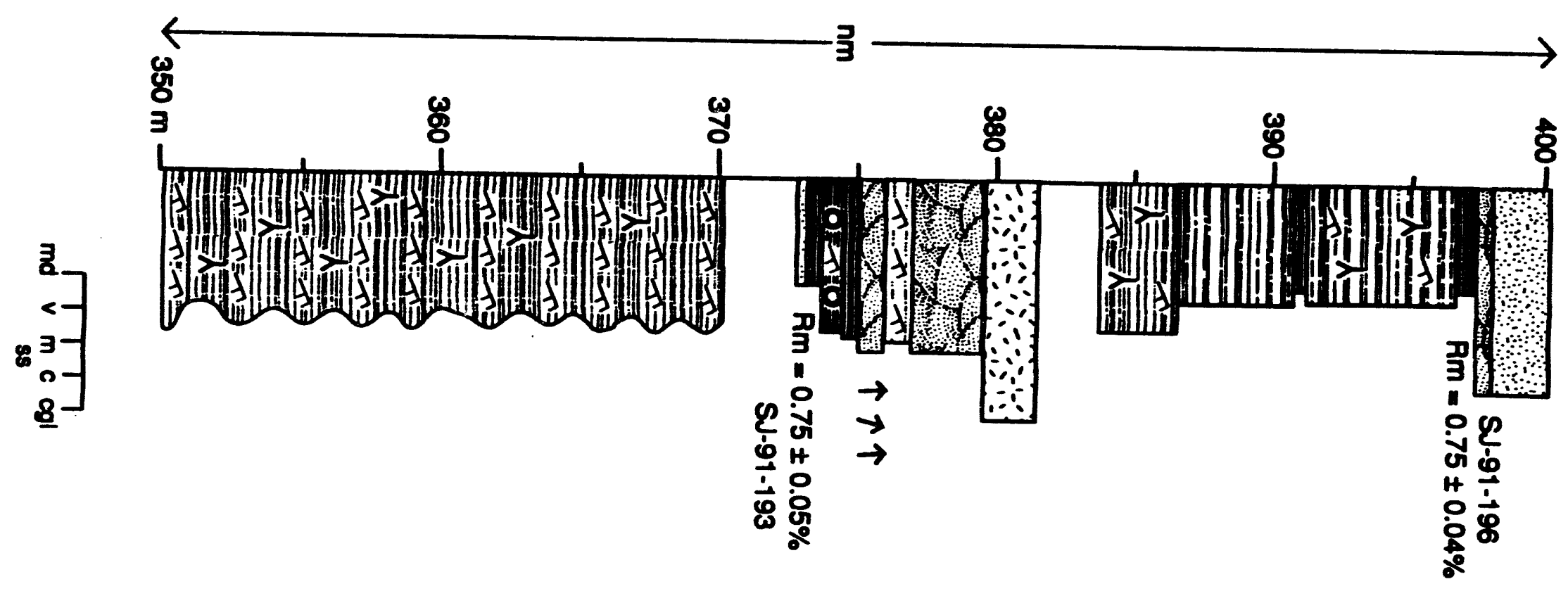



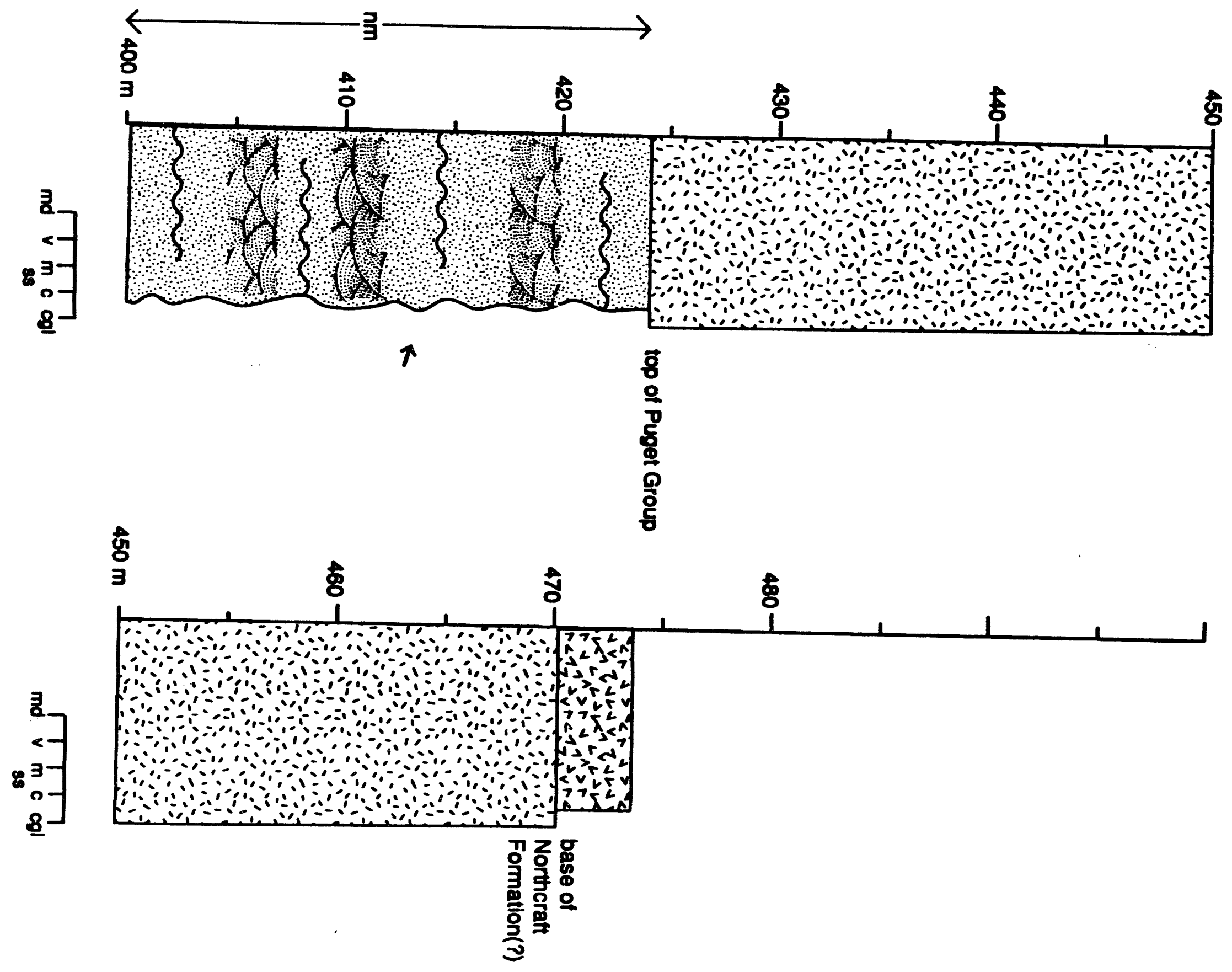


\section{Table A3-Vitrinite reflectance data for Bergen Mountain section.}


File Name: SJ $91-183$

Channe I Name: SJ-91-183

Descrtption: outcrop, coa1, good sample

Comment 1:

Comment 2:

Comment 3:

Comment 4:

Comment 5:

Comment 8:

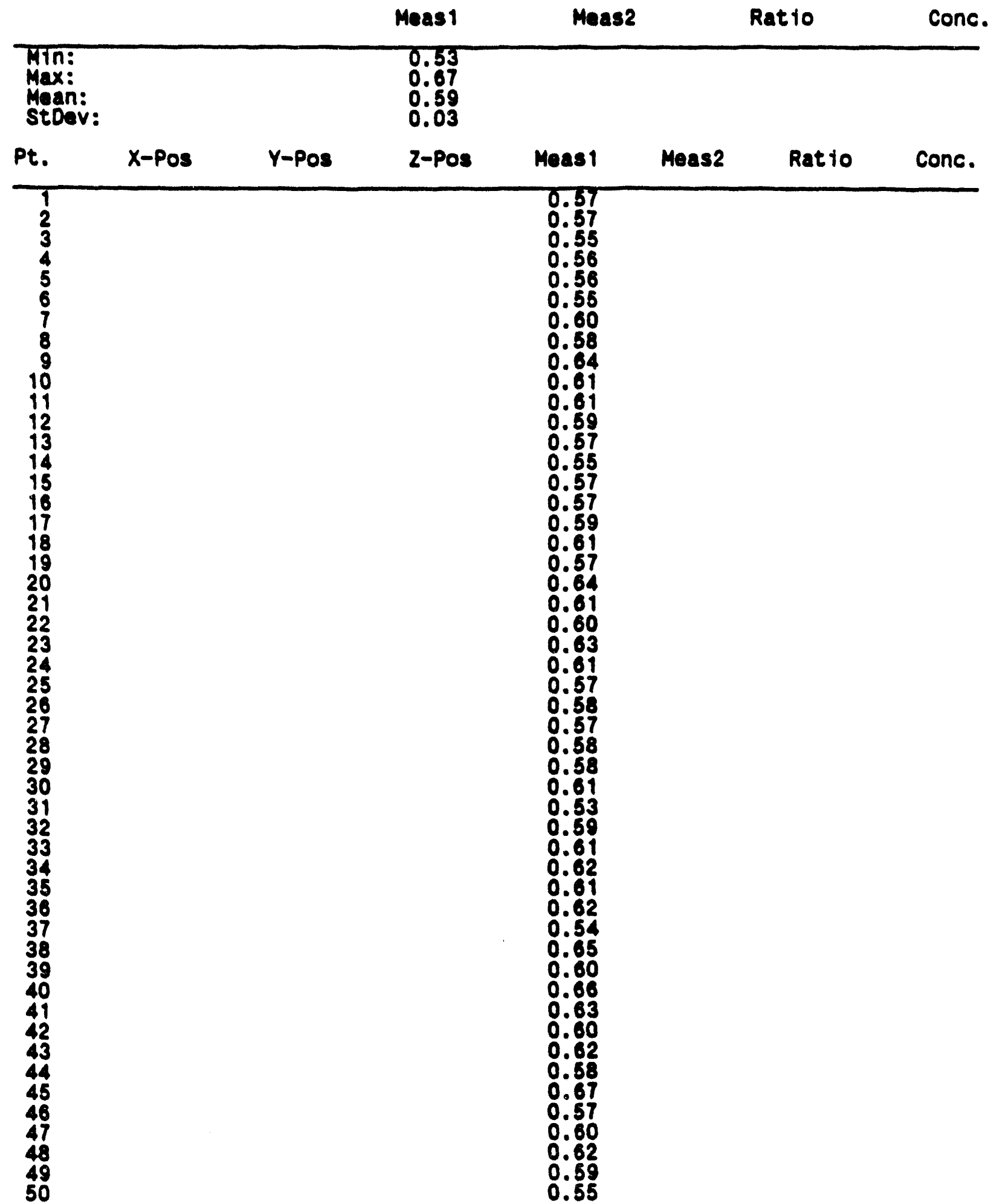


File Name: SJ-91188

Channel Name: SJ-91-188

Description: outcrop, coal good sample

Comment 1:

Comment 2:

Comment 3:

Comment 4:

Comment 5:

Comment 6:

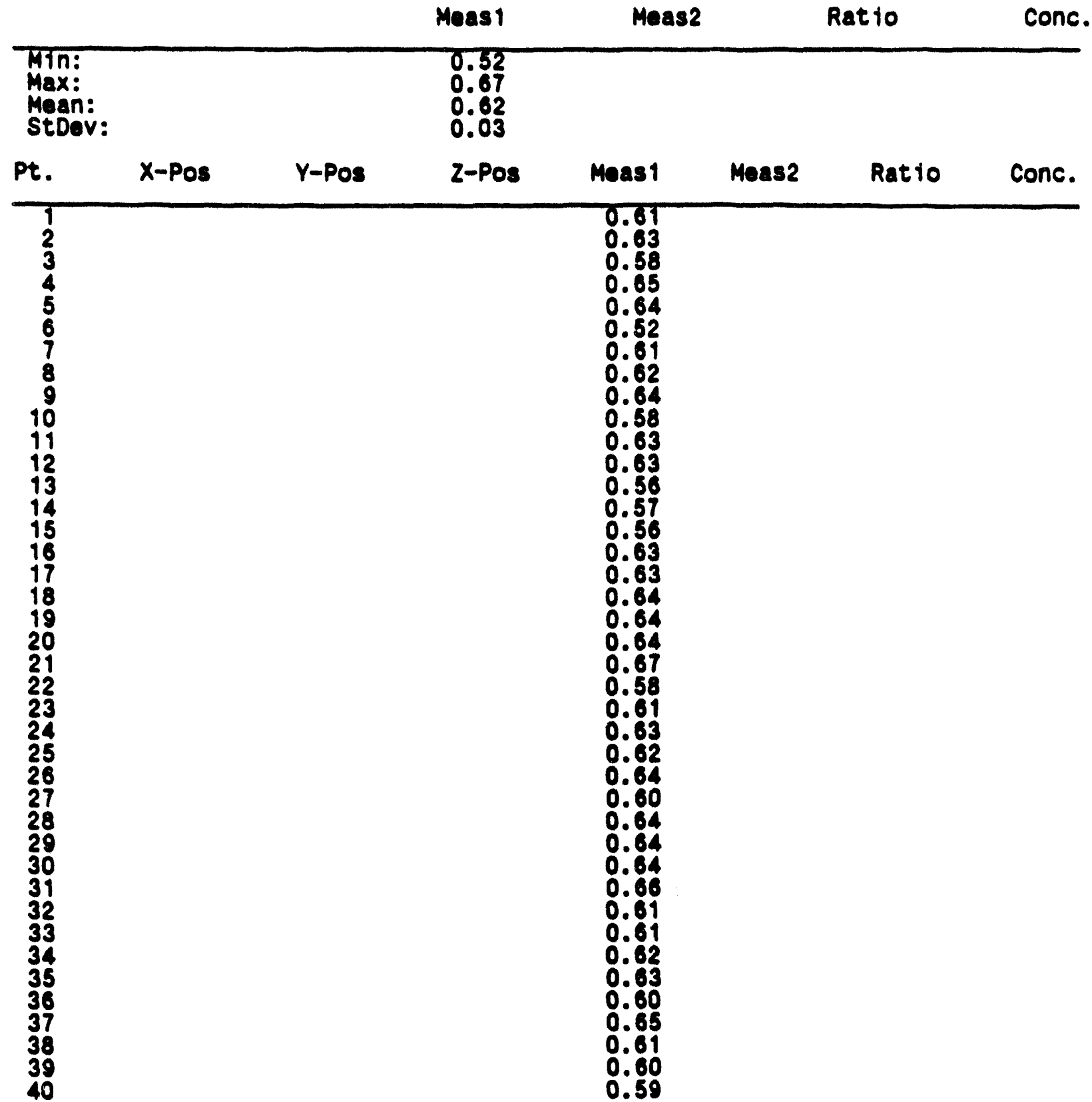


Flle Name: SJ-91193

Channel Nane: SJ-91-193

Description: outcrop, coal good sample

Comment 1:

Comment 2:

Comment 3:

Comment 4:

Comment 5:

Comment 6:

$\begin{array}{lcccc} & \text { Meas1 } & \text { Meas2 } & \text { Rat to } & \text { Conc. } \\ \text { Man: } & 0.67 & & \\ \text { Max: } & 0.83 & & \\ \text { Mean: } & 0.75 & & \\ \text { StDov: } & 0.05 & & \end{array}$

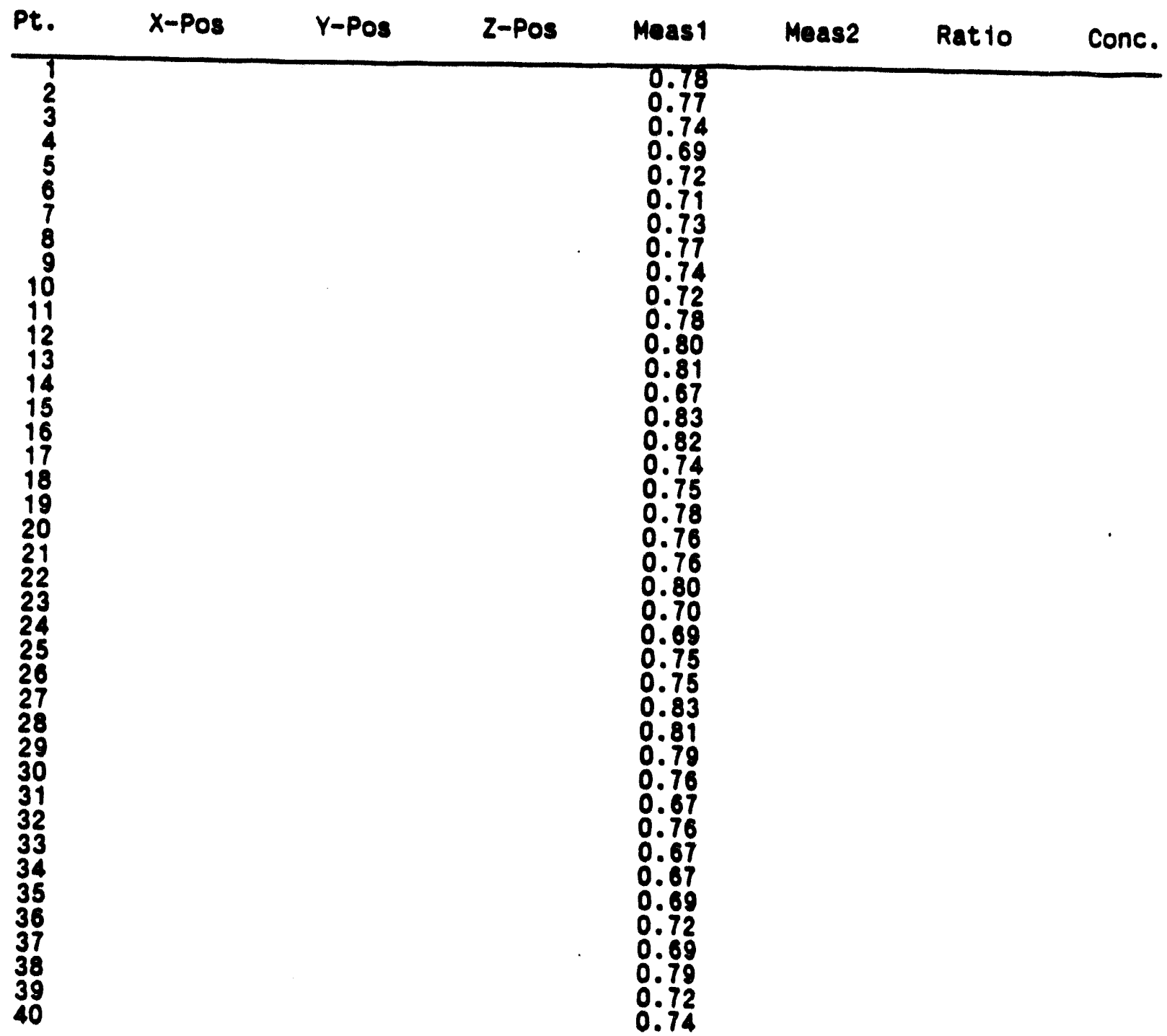




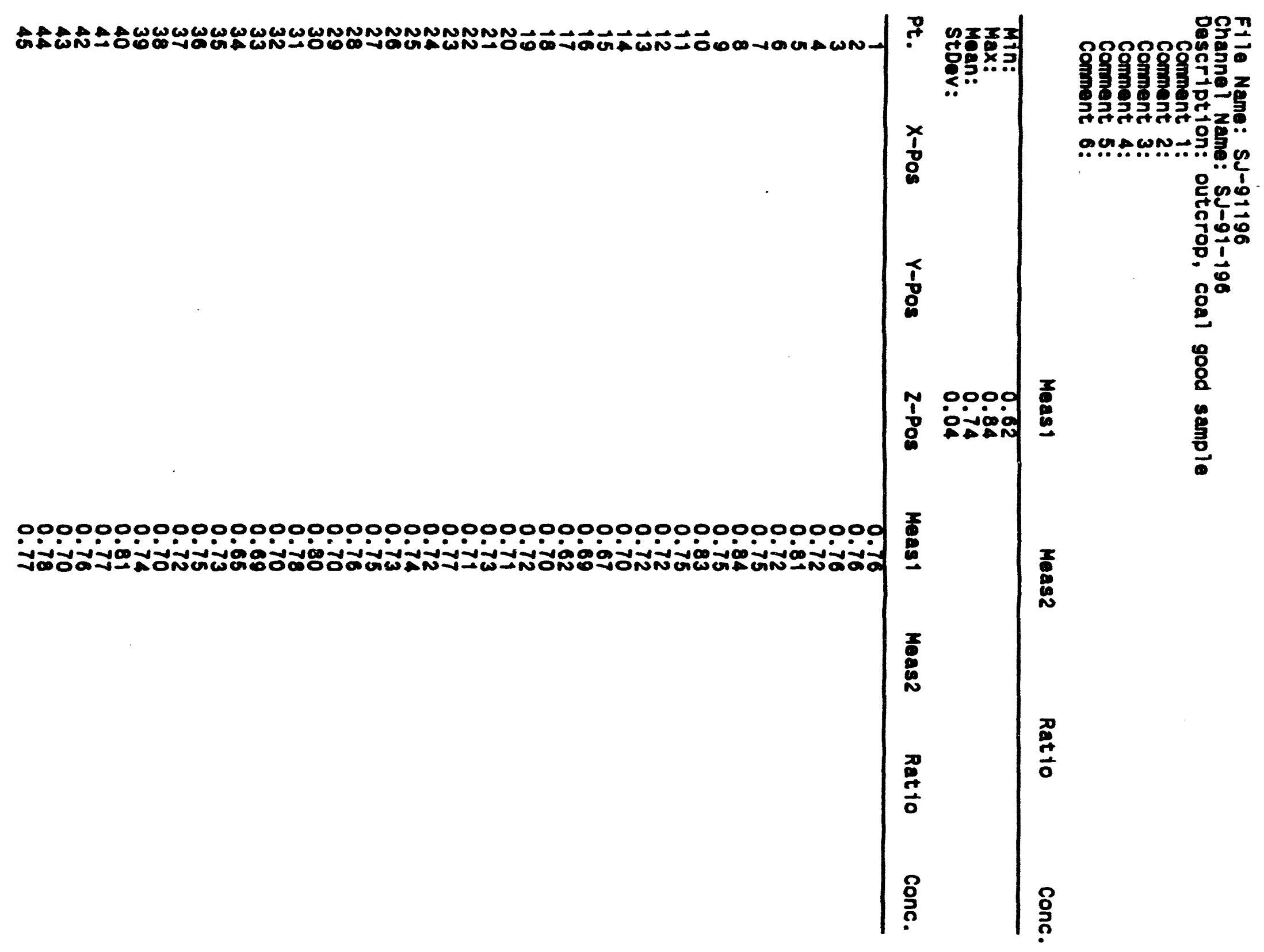


Snow Creek stratigraphic section

The Snow Creek stratigraphic section (Fig. A8) of the Carbonado Formation was measured in W 1/2, sec. 11 and NE 1/4, sec. 10, T. 13 N., R. 4 E. (The Rockles 7.5'

Figure A8-Location of snow Creek stratigraphic section.

U.S.G.S. topographic quadrangle). The section is nearly continuous, about $108 \mathrm{~m}$ thick, and was measured in the bed of Snow Creek late in the summer during low discharge. The base of the section corresponds to the lowest good creek-bed exposures in this area. The section (Fig. A9) is overlain by a thick (> $130 \mathrm{~m}$ )

Figure A9-Measured Snow Creak section lithology.

porphyritic intrusion. Strata of inferred nonmarine origin occur between 0-63 $\mathrm{m}$ and 73-79 $\mathrm{m}$ in the section. Strata of inferred shallow- to marginal-marine origin occur between $63-73 \mathrm{~m}$ and $79-108 \mathrm{~m}$ in the section. Vitrinite reflectance was analyzed for two samples. 


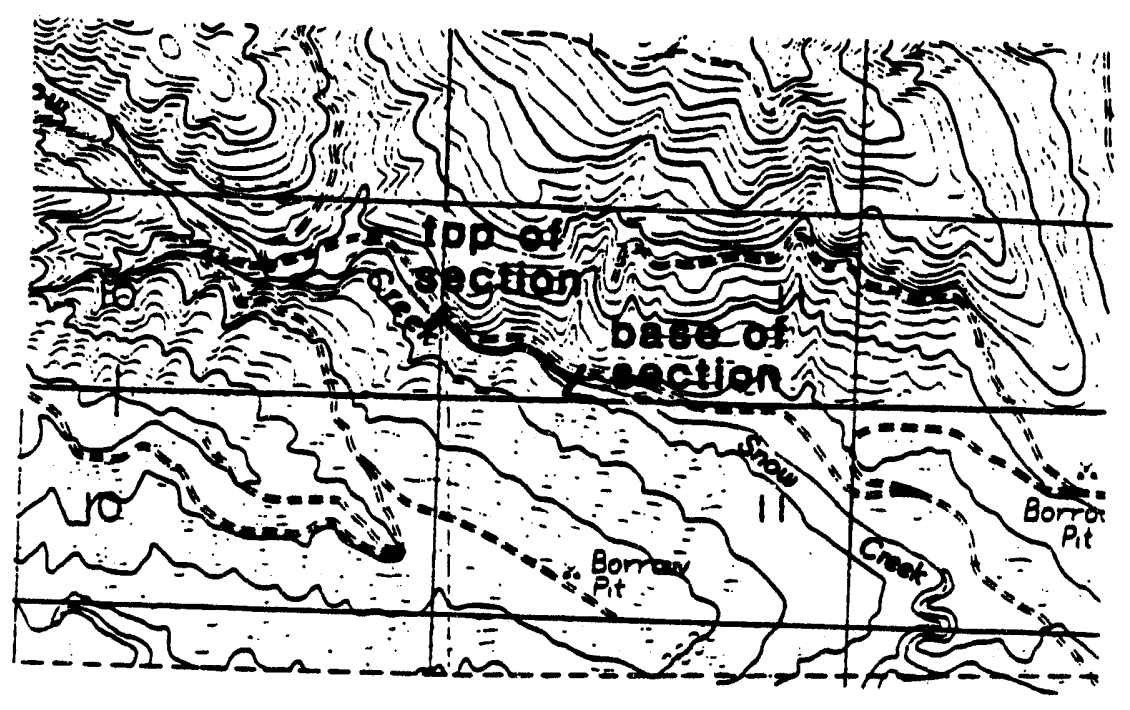

Figure A 8 

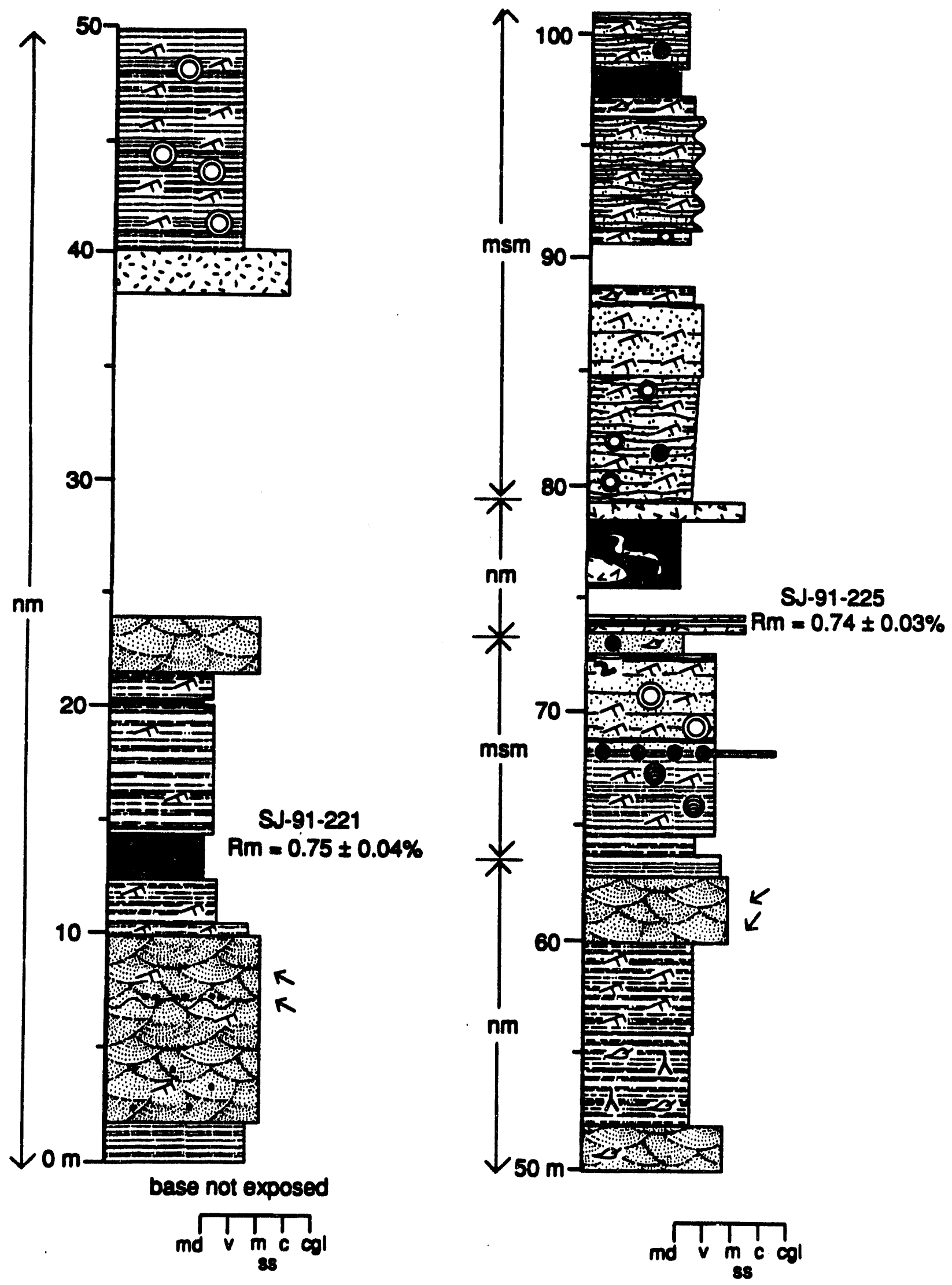

Figure A 9 


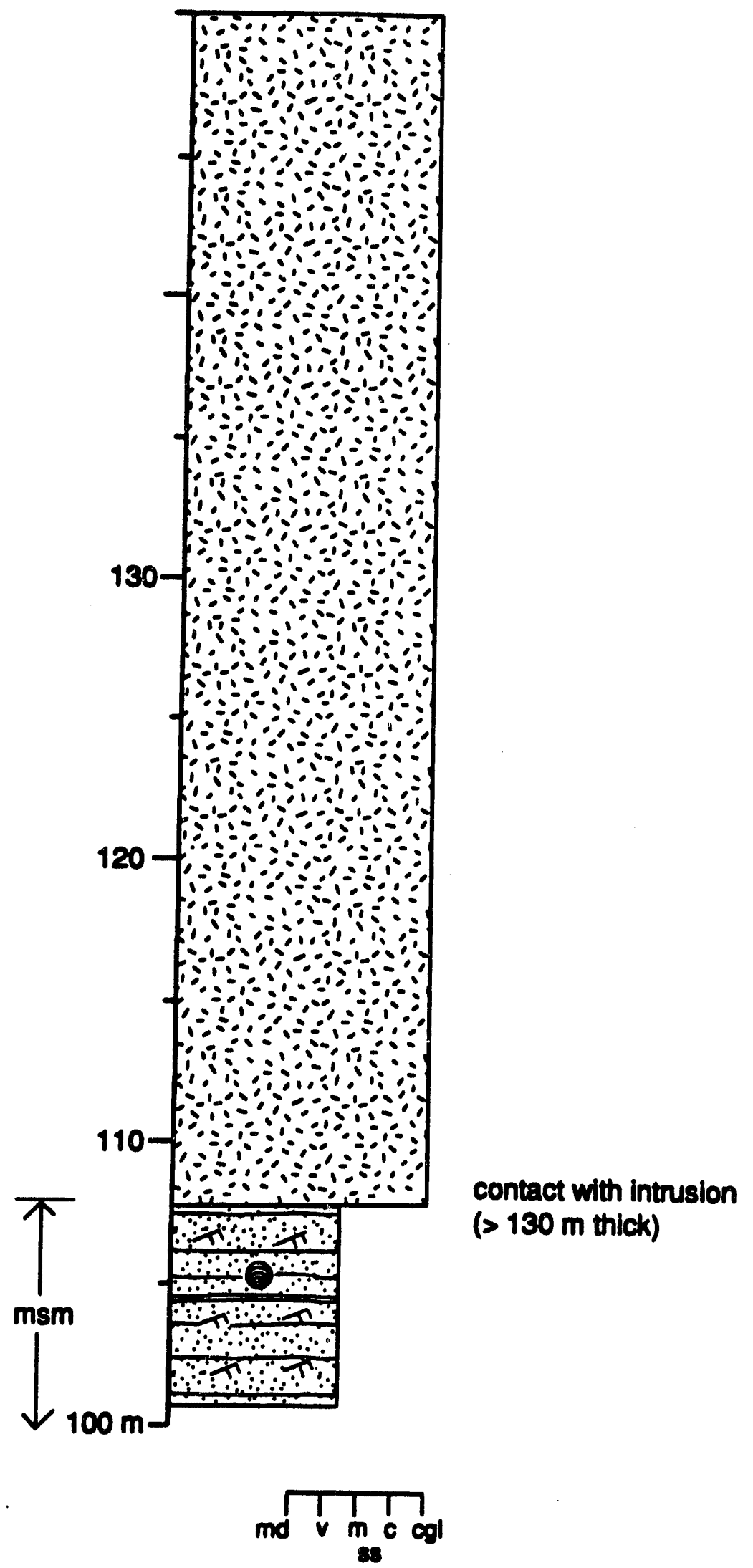


Table A4-Vitrinlte reflectance data for snow creek section. T... $+2$ 
File Name: SJ91-221

Channel Name: SJ-91-221

Description: outcrop, coal, good sample Comment $1:$

Comment 2:

Comment 3:

Comment 4:

Comment 5:

Comment 6:

\begin{tabular}{lc} 
& Meas \\
\hline Mrn: & 0.65 \\
Max: & 0.84 \\
Mean: & 0.75 \\
StDev: & 0.04
\end{tabular}

Pt.

X-Pos Y-Pos Z-Pos

Meas2

Rat to

Conc.

\begin{tabular}{|c|c|}
\hline $\begin{array}{r}1 \\
2 \\
3 \\
4 \\
5 \\
6 \\
7 \\
8 \\
9 \\
10 \\
11 \\
12 \\
13 \\
14 \\
15 \\
16 \\
17 \\
18 \\
19 \\
20 \\
21 \\
22 \\
23 \\
24 \\
25 \\
26 \\
27 \\
28 \\
29 \\
30 \\
31 \\
32 \\
33 \\
34 \\
35 \\
36 \\
37 \\
38 \\
39 \\
40 \\
41 \\
42 \\
43 \\
44 \\
45 \\
46 \\
47 \\
48 \\
49 \\
50\end{array}$ & $\begin{array}{l}0.79 \\
0.76 \\
0.75 \\
0.76 \\
0.77 \\
0.69 \\
0.73 \\
0.80 \\
0.81 \\
0.72 \\
0.79 \\
0.77 \\
0.80 \\
0.79 \\
0.79 \\
0.70 \\
0.68 \\
0.70 \\
0.80 \\
0.75 \\
0.70 \\
0.70 \\
0.89 \\
0.78 \\
0.76 \\
0.76 \\
0.88 \\
0.79 \\
0.76 \\
0.76 \\
0.76 \\
0.71 \\
0.73 \\
0.75 \\
0.76 \\
0.70 \\
0.76 \\
0.77 \\
0.71 \\
0.72 \\
0.65 \\
0.71 \\
0.84 \\
0.83 \\
0.78 \\
0.70 \\
0.71 \\
0.70 \\
0.68 \\
0.73\end{array}$ \\
\hline
\end{tabular}


File Name: SJ91-225

Channe1 Name: SJ-91-225

Description: outcrop, coal, good sample

Comment 1:

Comment 2:

Comment 3:

Comment 4:

Comment 5:

Comment 6:

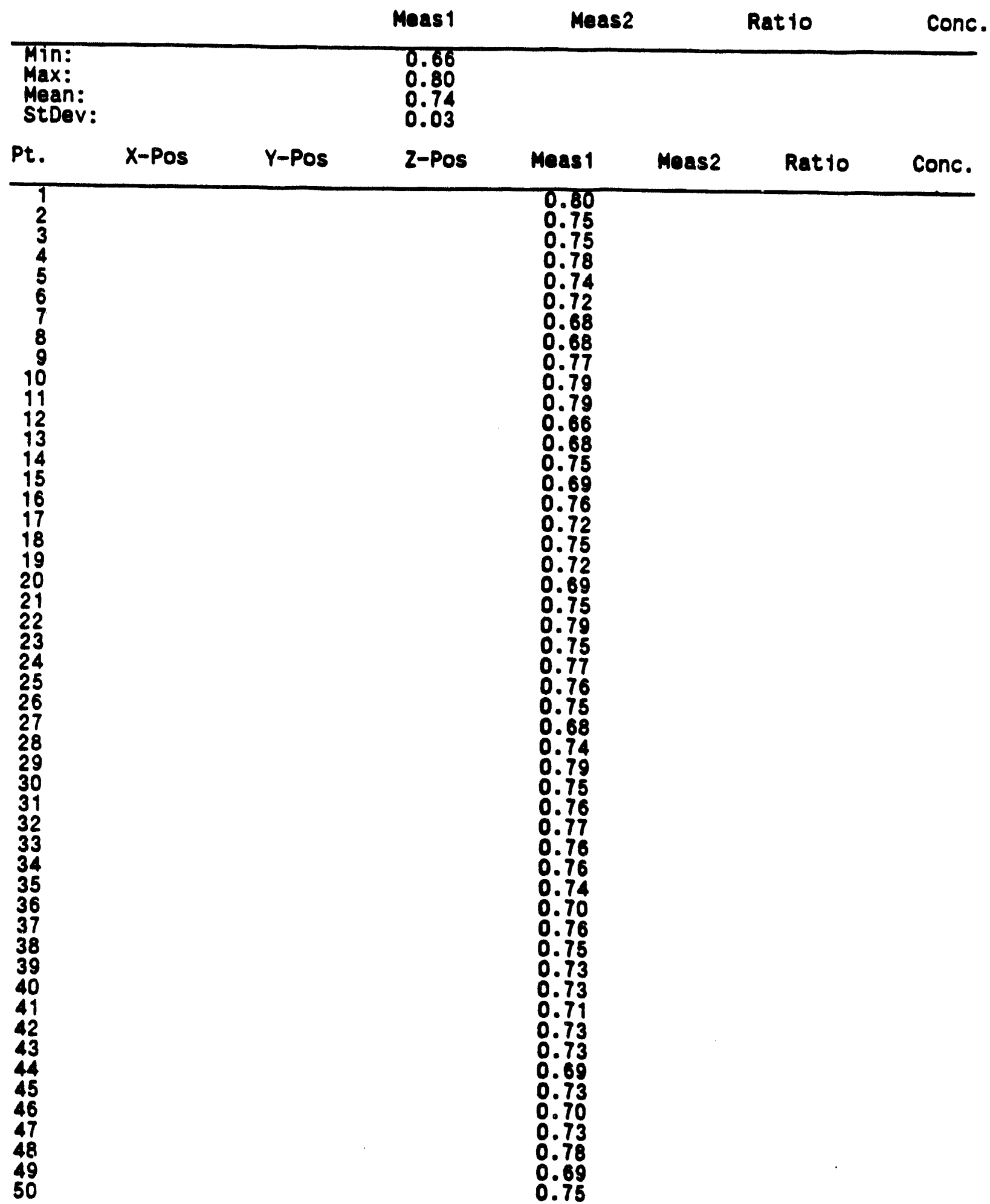


South Fork of Tilton River stratigraphic section

The Coal Creek stratigraphic section (Fig. A10) of the Carbonado Formation was measured in NW 1/4, sec. 32, T. 13 N., R. 5 E. (Glenoma 7.5' U.S.G.S. topographic quadrangle). The section is approximately $272 \mathrm{~m}$ thick. The lower $134 \mathrm{~m}$ of the

Figure A10-Location of south Fork Tilton River (Coal Creek) stratigraphic section.

section were measured in well-exposed cuts along logging roads on the south flank of the valley of the South Fork of the Tilton River; the base of the section corresponds to the lowest exposures on this road network. Strate (Fig. A11) of inferred nonmarine origin occur between 0-20 m, 62-78, and 126-134 $\mathrm{m}$ in this lower interval. Strata of inferred shallow- to marginal-marine origin occur between $20-68 \mathrm{~m}$ and $78-126 \mathrm{~m}$ in

Figure All-South Fork Tilton River measured section data.

this lower interval. The section is covered from approximately 134 to $204 \mathrm{~m}$. The upper $70 \mathrm{~m}$ are poorly exposed in the steep flanks of a small drainage. This upper interval consists entirely of sandstone and has an inferred nonmarine origin. This section is overlain by poorly exposed, fine-grained volcanic rocks considered here as part of the Northcraft Formation. This contact is lower on tine valley flank than mapped by Schasse (1987). Two samples were analyzed for vitrinite reflectance. 


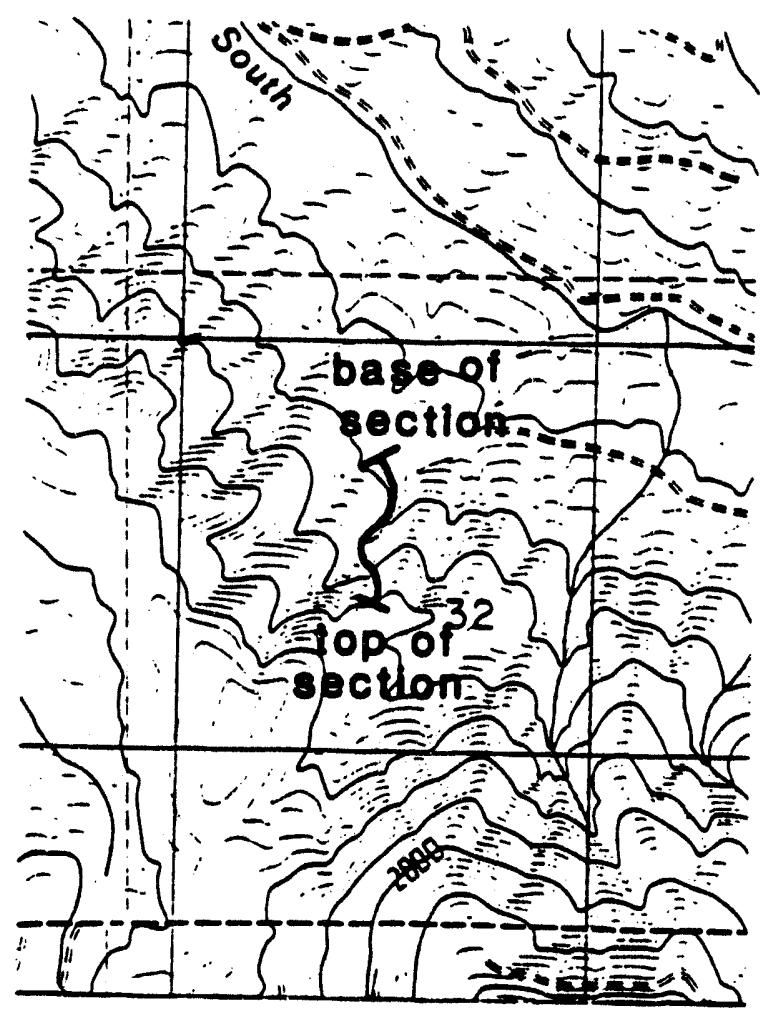

Figure A10 

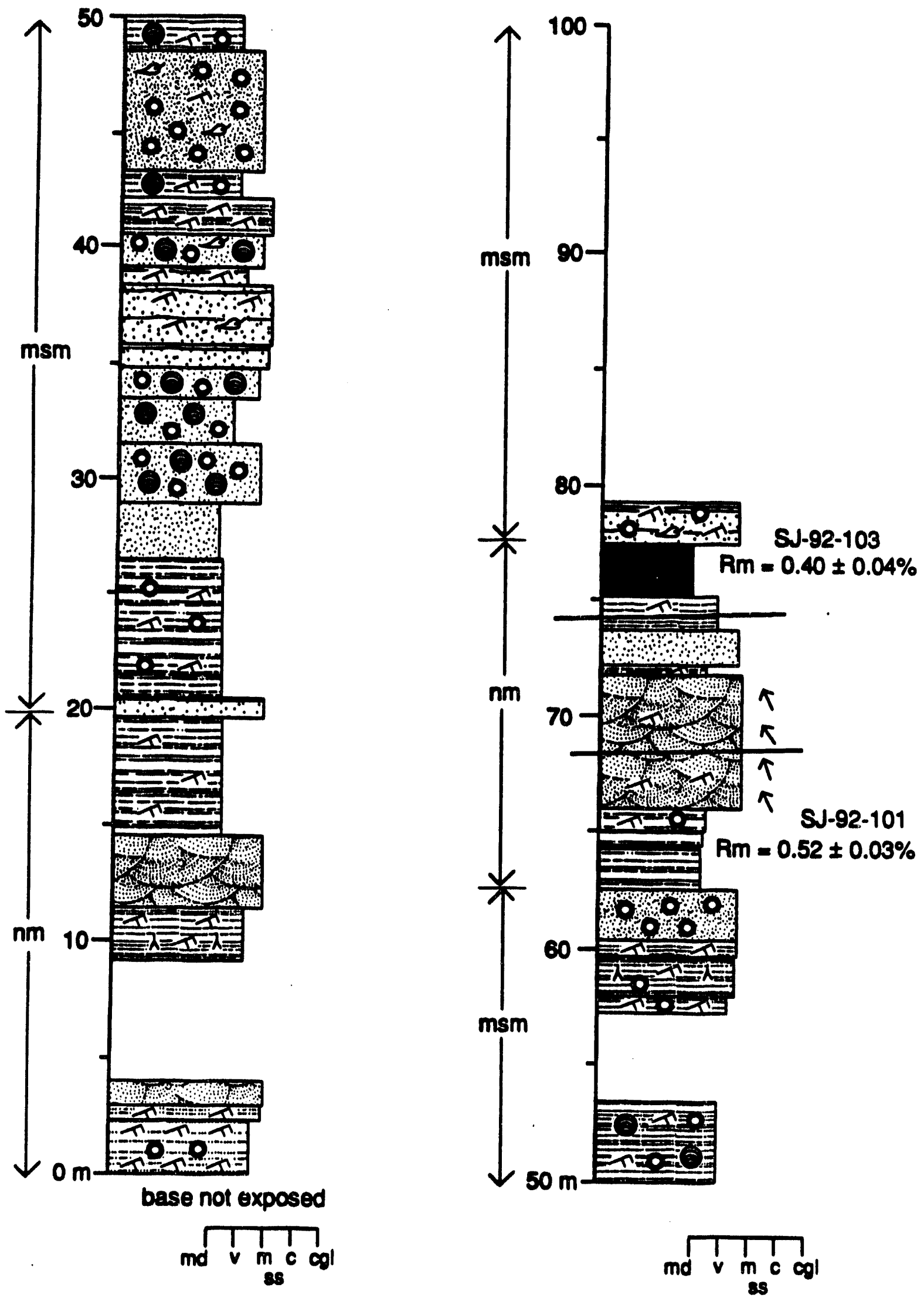

Figure A11 

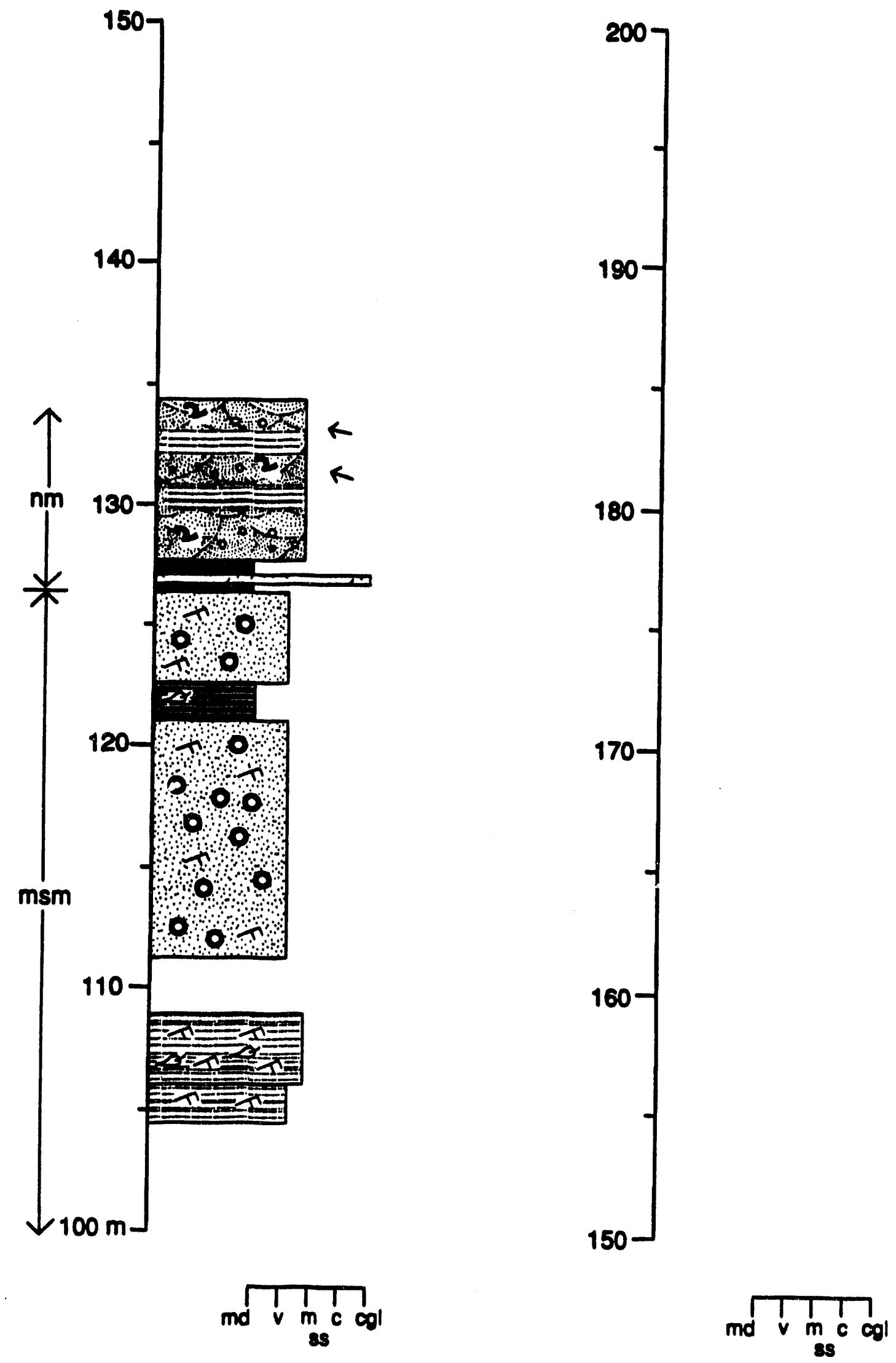

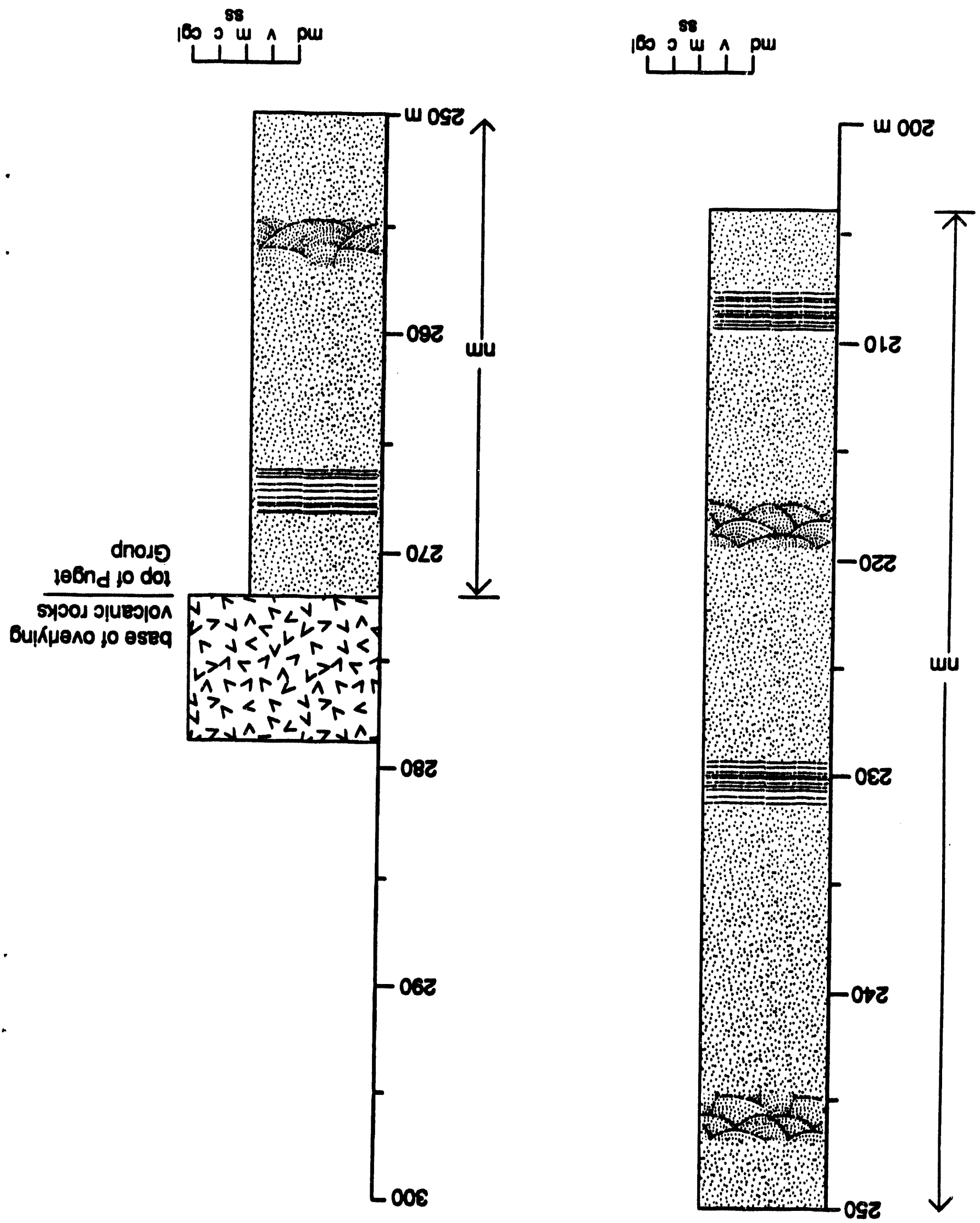
Table A5-Vitrinite reflectance data for south Fork Tilton River eamples. 
F1le Name: SJ92-101

Channe 1 Name: SJ-92-101

Description: SJ-92-101

Comment 1: good sample

Comment 2: consistent and clean

Comment 3: polish good

Comment 4:

Comment 5:

Comment 6:

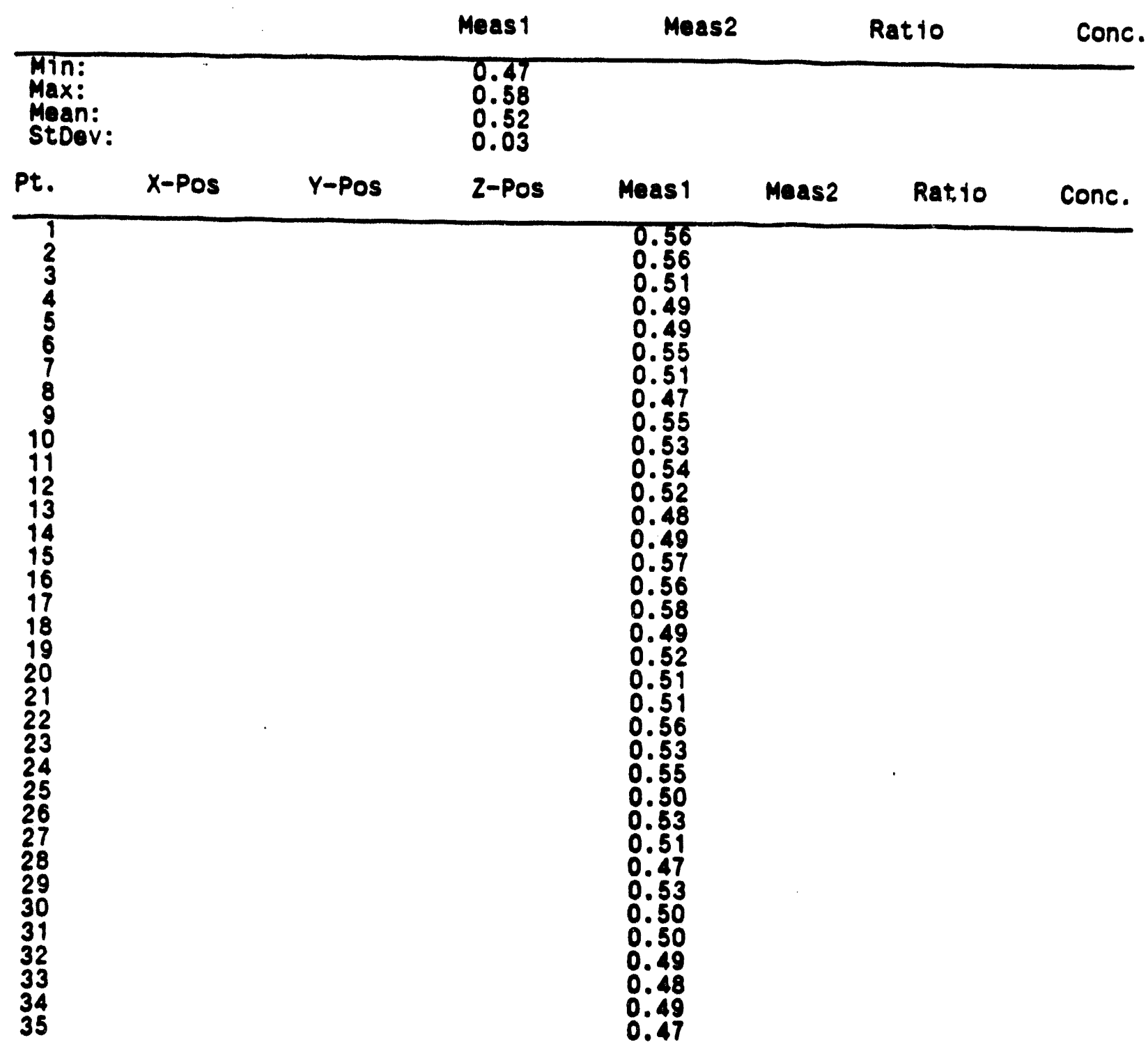


File Name: SJ92-103

Channel Name: SJ-92-103

Description: SJ-92-103

Comment 1: good sample

Comment 2: consistent and clean

Comment 3: polish fair

Comment 4:

Comment 5:

Comment 6:

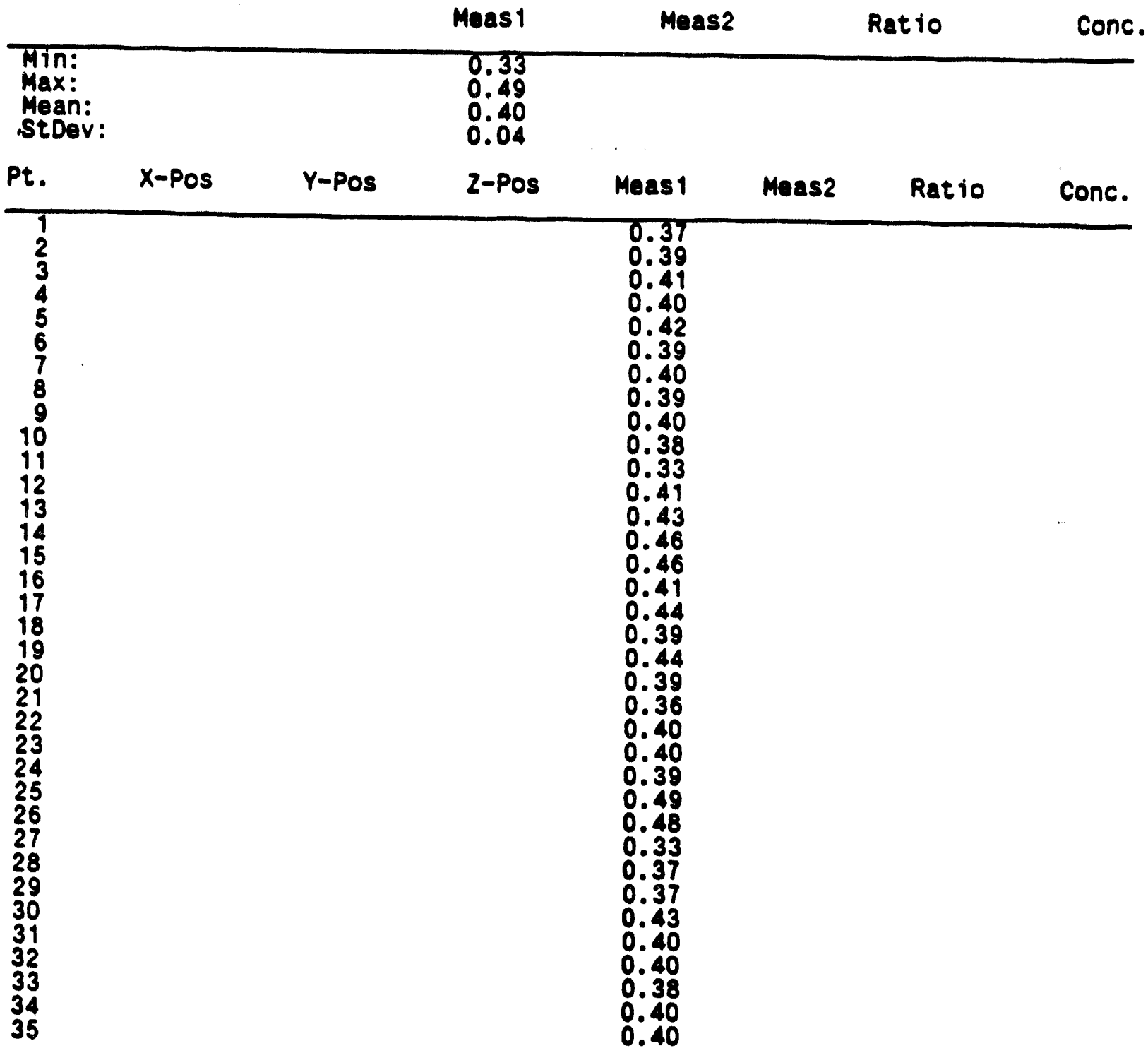




\section{Bear Canyon stratigraphic section}

The Bear Canyon stratigraphic section (Fig. A12) of the Carbonado Formation was measured in SE 1/4, sec. 18, T. 13 N., R. 3 E. (Mossyrock 7.5' U.S.G.S.

\section{Figure a12- Bear Canyon measured section location.}

topographic quadrangle). The section is about $33 \mathrm{~m}$ thick. Exposures are on the east flank of Bear Canyon, beginning with a Highway 508 roadcut and ending with exposures on steep valley walls north of the Highway. Neither top or base of the section are exposed. The lower $11 \mathrm{~m}$ of the section (Fig. A13) are of inferred shallow- to marginal-marine origin. The upper $22 \mathrm{~m}$ of the section are of inferred nonmarine origin. No vitrinite reflectance data is available for this section as of this

Figure A13-yeasured section at Bear Canyon.

date. 


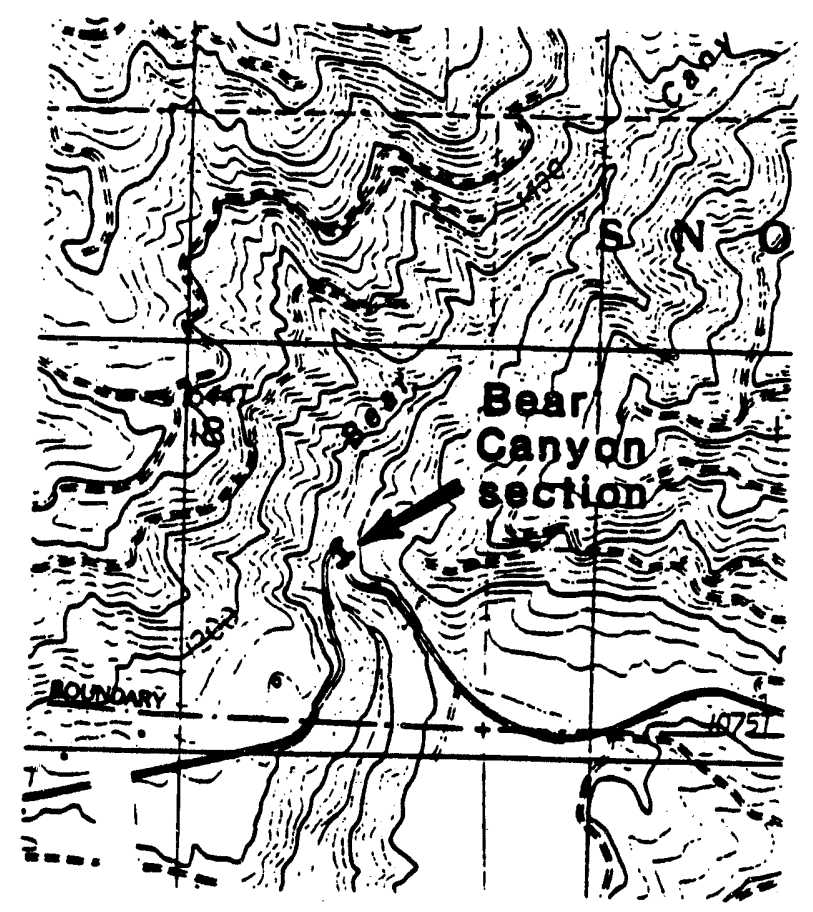

Figure A12 


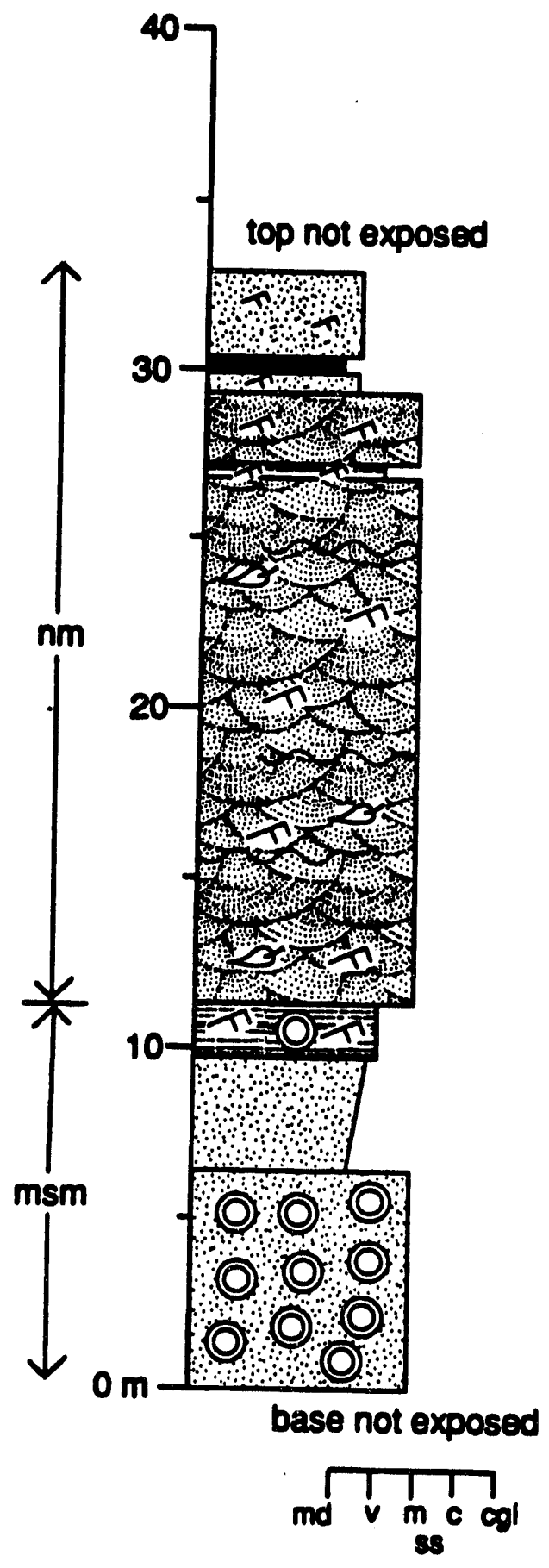

Figure A13 


\section{Appendix B}

Velocity Information

The sonic logs on the following pages are from selected wells in the Chehalis Basin used to assess the velocities of the sedimentary and volcanic rocks. These were compared to stacking velocities and empirical velocity estimates for sedimentary rocks as shown in Figure 15. 


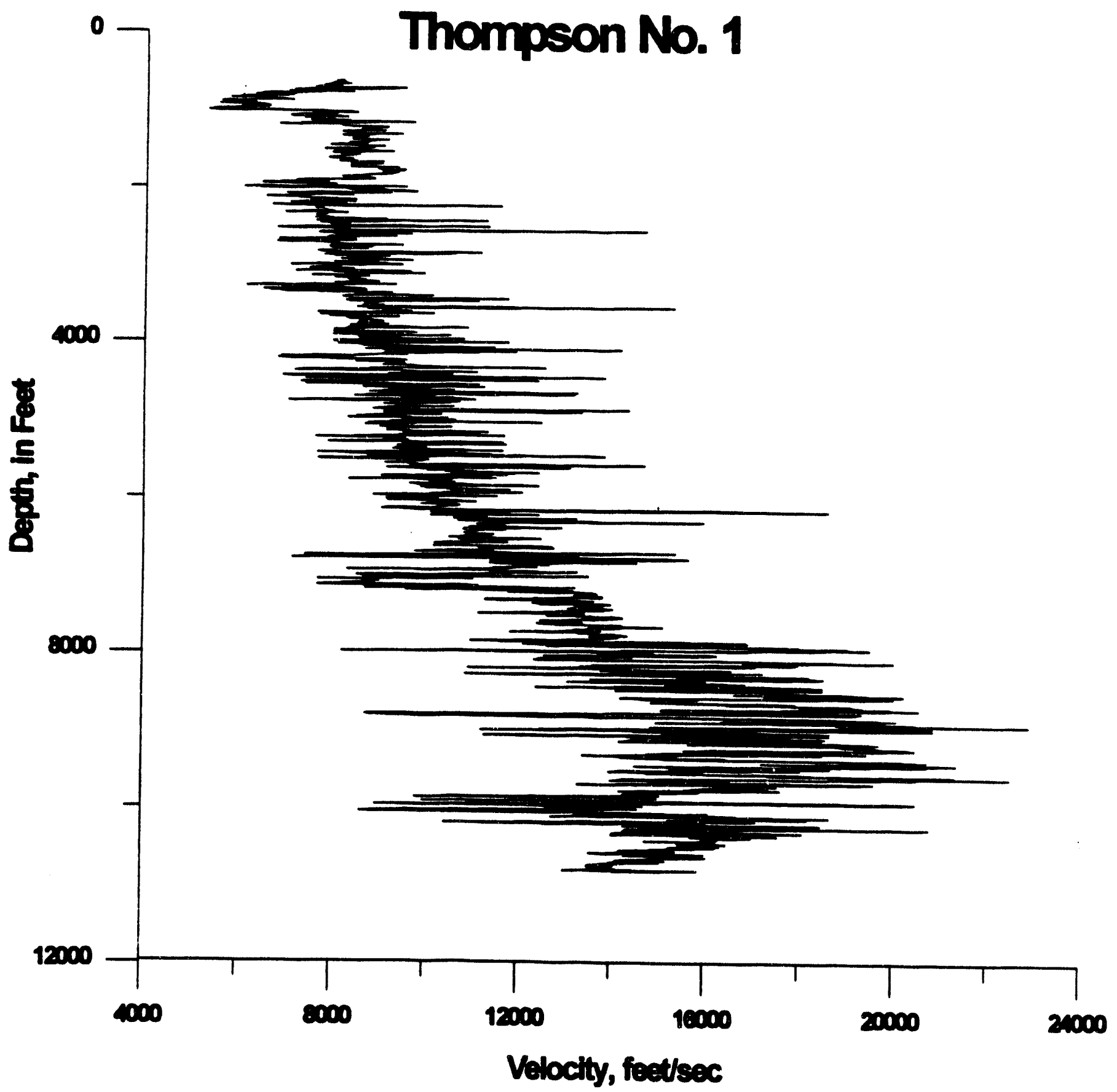




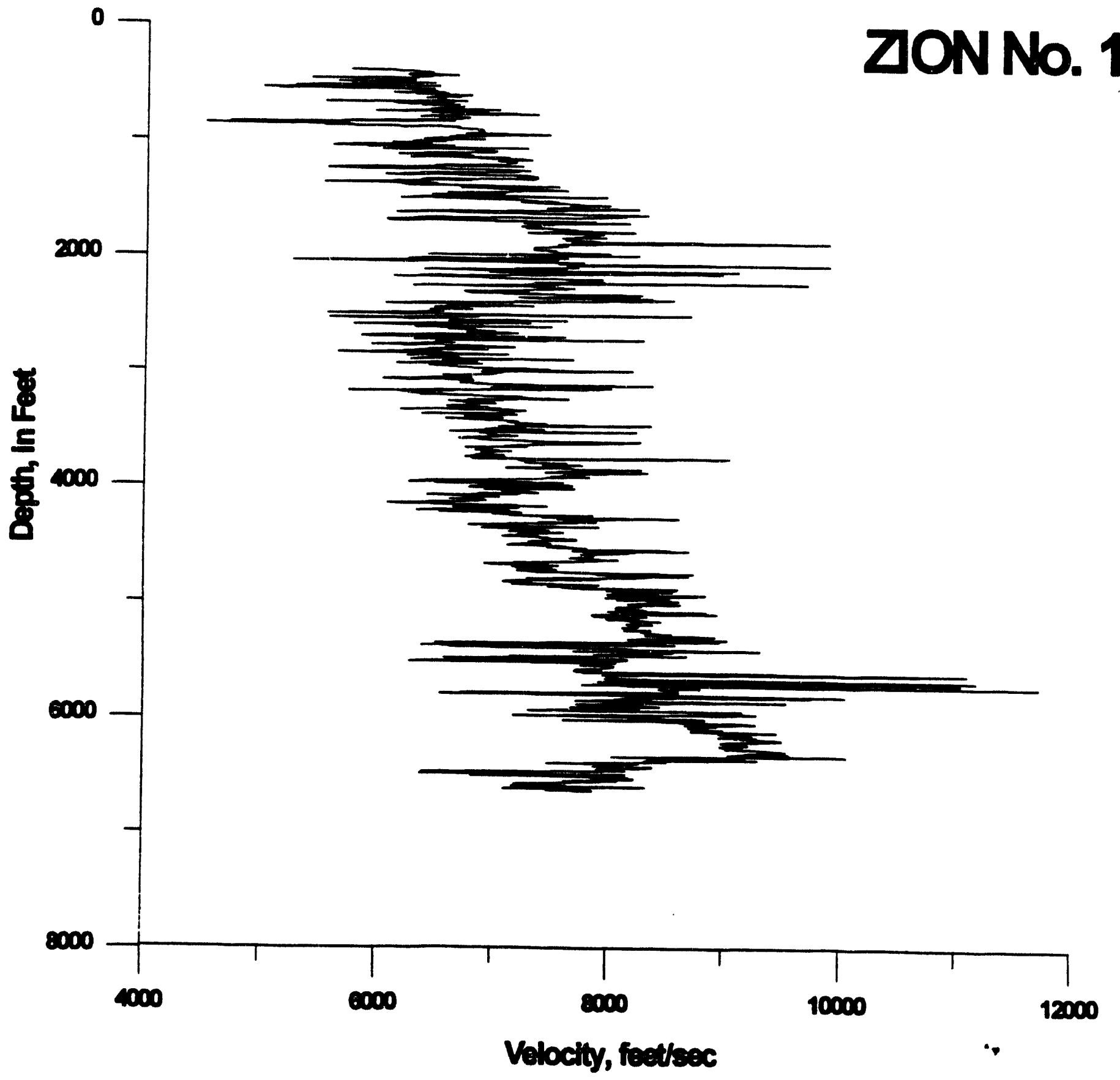




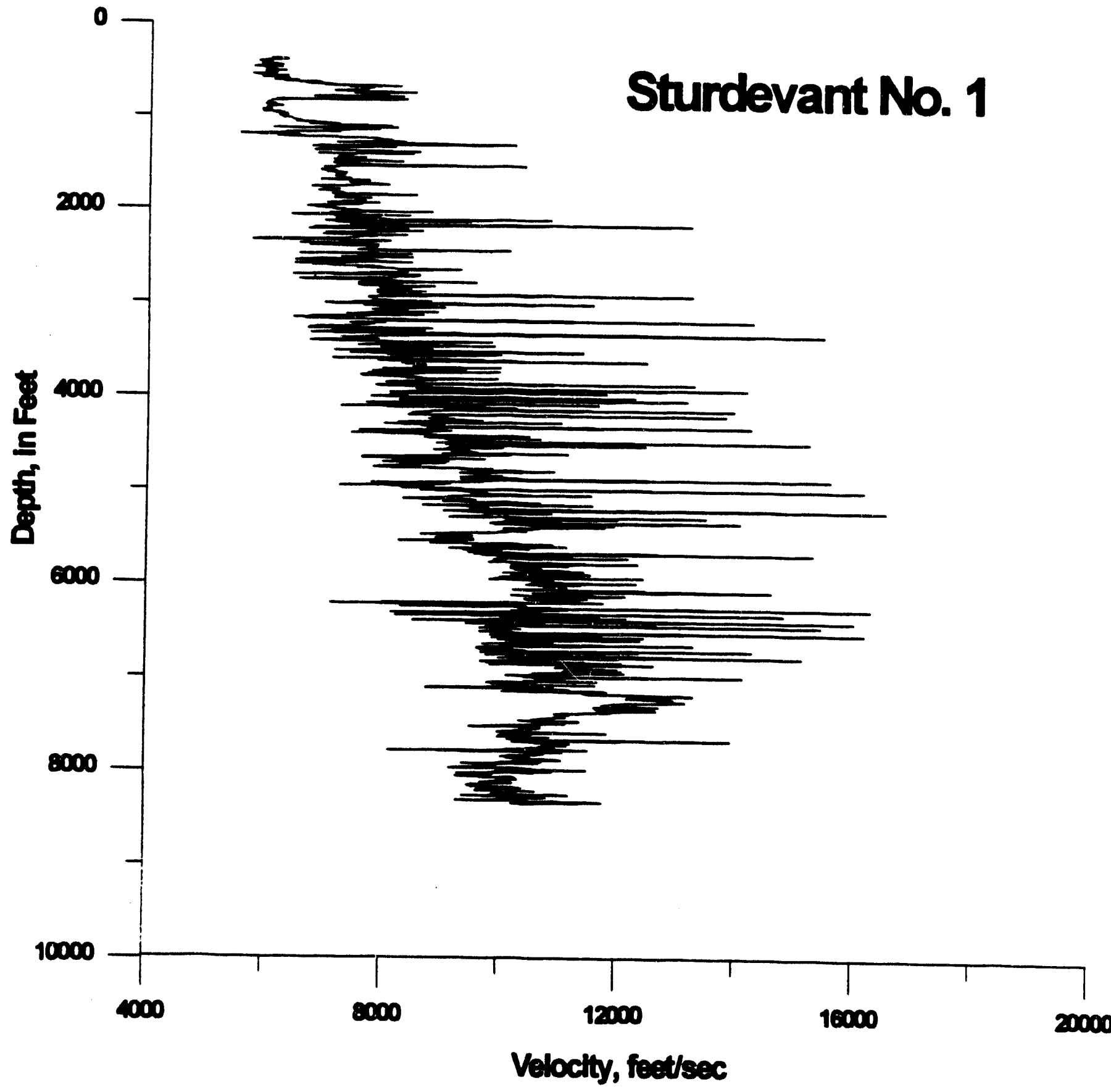




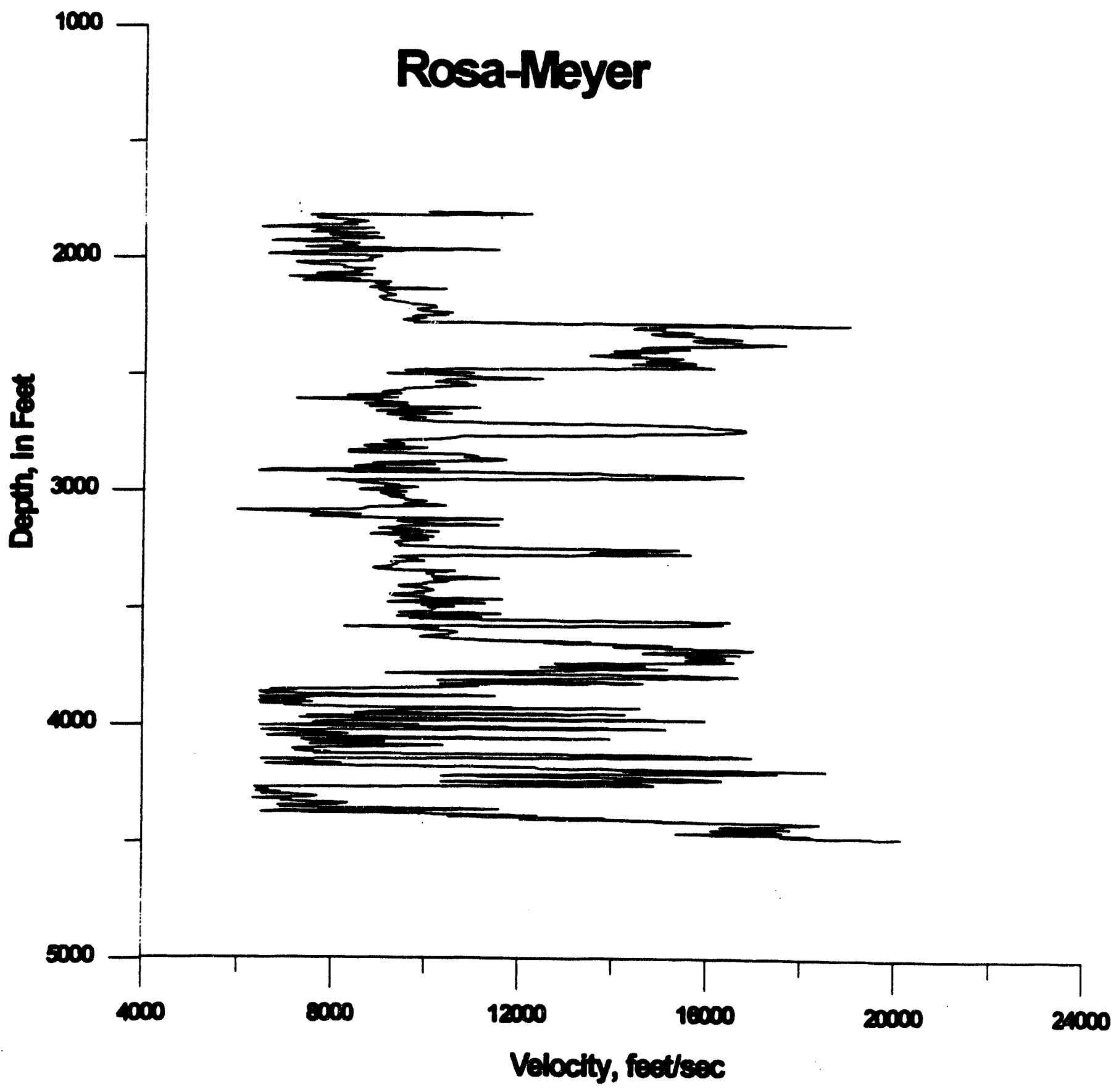




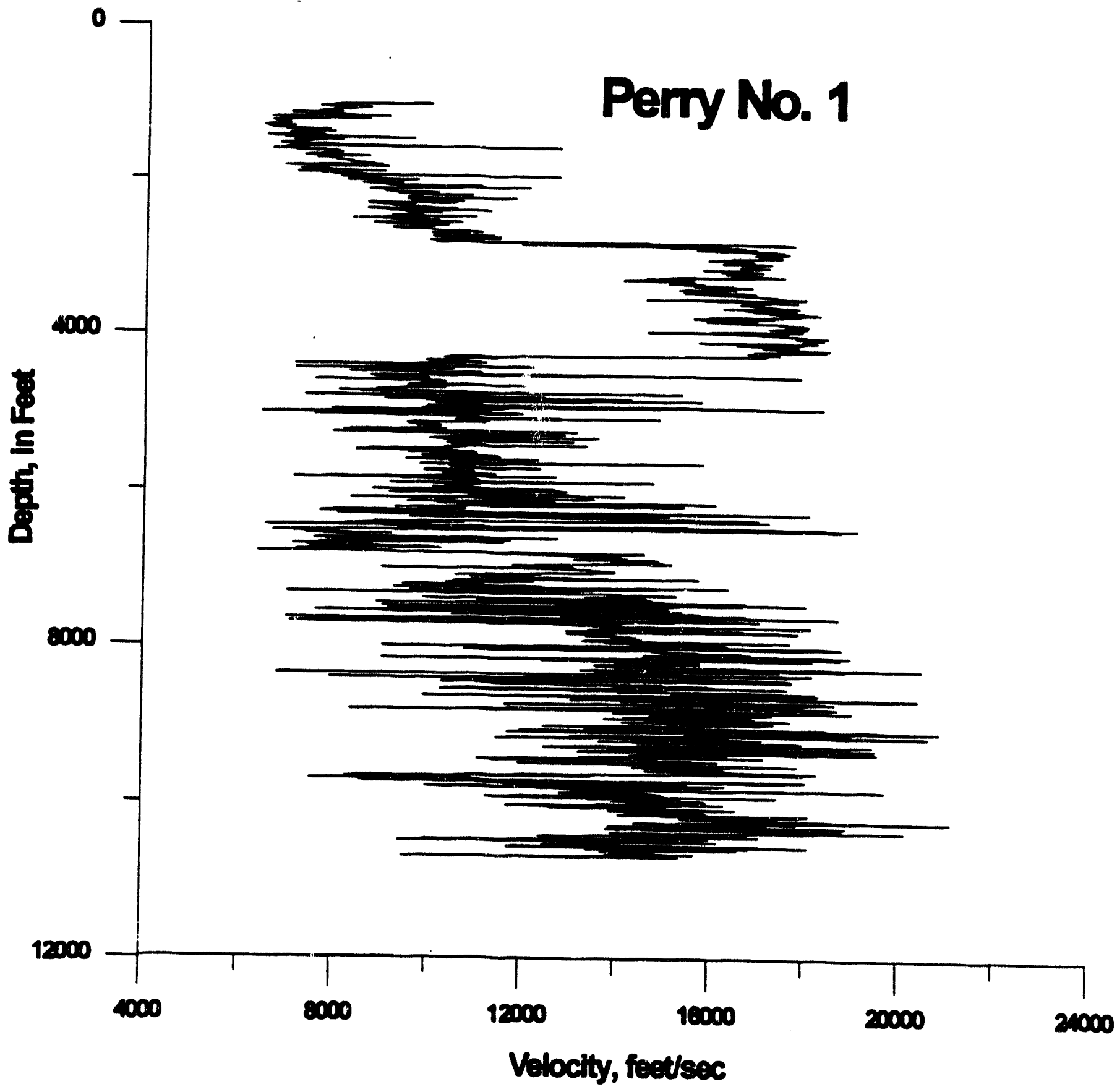




\section{Shotooint Locations}

Shotpoint location table for the DOE seismic lines follow. Exact shotpoint locations can be keyed to the geologic map of Figure 2 by counting off by tens. Line 4 shotpoints run from east to west, line 5 from south to north, and the remainder run from east to west. 
<line id > < spt > U UTM x > U UTM y > <longitude > <latitude >

LINE-1\&2

LINE-1\&2

LINE-1\&2

LINE-1 22

LINE-182

LINE-1 22

LINE-1\&2

LINE-1\&2

LINE-1\&2

LINE-1 22

LINE-1\&2

LINE-1 22

LINE-1 22

LINE-1 \&2

LINE-1\&2

LINE-1\&2

LINE-1\&2

LINE-1\&2

LINE-1\&2

LINE-1\&2

LINE-1\&2

LINE-1\&2

LINE-1\&2

LINE-1\&2

LINE-1\&2

LINE-1\&2

LINE-1\&2

LINE-1\&2

LINE-1\&2

LINE-1\&2

LINE-1\&2

LINE-1\&2

LINE-1\&2

LINE-1\&2

LINE-1\&2

LINE-1\&2

LINE-1\&2

LINE-1\&2

LINE-1\&2

LINE-1\&2

LINE-1\&2

LINE-1\&2

LINE-1\&2

LINE-1\&2
$101538210.6250005153621 .500000-122.501701$

$110538478.6250005153611 .000000-122.498207$

$120538781.125000 \quad 5153600.500000-122.494263$

$130539054.1875005153627 .000000-122.490700$

$140539352.187500 \quad 5153679.000000-122.486809$

$150539645.375000 \quad 5153761.500000-122.482979$

$160539938.6250005153828 .000000-122.479149$

$\begin{array}{llll}170 & 540236.625000 & 5153890.500000 & -122.475258\end{array}$

$180540514.3750005153998 .500000-122.471626$

$190540781.312500 \quad 5154153.500000-122.468132$

$200 \quad 541033.3750005154324 .500000-122.464828$

$210 \quad 541296.187500 \quad 5154475.000000-122.461388$

$220 \quad 541562.8125005154582 .500000-122.457901$

$230541861.312500 \quad 5154644.500000 \quad-1.22 .454002$

$240542159.500000 \quad 5154665.500000-122.450111$

$250542458.0000005154645 .500000-122.446220$

$260542756.3750005154630 .000000-122.442329$

$270543053.8750005154588 .500000-122.438454$

$280543347.1250005154485 .000000-122.434639$

$290543588.8125005154314 .500000-122.431503$

$\begin{array}{llll}300 & 543825.875000 & 5154123.000000 & -122.428429\end{array}$

$310 \quad 544093.125000 \quad 5153983.500000-122.424957$

$320544385.500000 \quad 5133921.500000-122.421150$

$330544689.500000 \quad 5153875.000000-122.417191$

$340544992.5000005153874 .500000-122.4 i 3239$

$350545295.687500 \quad 5153937.000000-122.409279$

$360545584.125000 \quad 5153942.500000-122.405518$

$370545845.6250005153782 .000000-122.402122$

$380546092.812500 \quad 5153601.000000-122.398918$

$390546360.625000 \quad 5153466.000000-122.395439$

$400546643.125000 \quad 5153399.500000-122.391762$

$410546946.312500 \quad 5153389.500000-122.387810$

$420547249.875000 \quad 5153399.500000-122.383850$

$430 \quad 547507.312500 \quad 5153549.500000-122.380478$

$440547763.500000 \quad 5153699.000000-122.377121$

$450547989.500000 \quad 5153905.500000-122.374153$

$460 \quad 548226.687500 \quad 5154097.500000-122.371040$

$\begin{array}{llll}470 & 548468.500000 & 5154289.500000 & -122.367867\end{array}$

$480548735.3750005154418 .000000-122.364372$

$490549038.500000 \quad 5154413.000000-122.360420$

$500549327.3125005154366 .000000-122.356659$

$510 \quad 549624.6250005154351 .000000-122.352783$

$520549871.6875005154536 .500000-122.349541$

$530 \quad 550124.125000 \quad 5154713.000000 \quad-122.346230$
46.537041

46.536930

46.536819

46.53704:

46.537491

46.538219

46.538799

46.539341

46.540298

46.541679

46.543201

46.544540

46.545490

46.546028

46.546200

46.546001

46.545841

46.545448

46.544498

46.542950

46.541210

46.539940

46.539360

46.538921

46.538898

46.539440

46.539471

46.538010

46.536362

46.535130

46.534512

46.534401

46.534470

46.535801

46.537128

46.538971

46.540680

46.542389

46.543530

46.543461

46.543018

46.542858

46.544510

46.546082 
LINE-1\&2

LINE-1\&2

LINE-1\&2

LINE-1\&2

LINE-1 82

LINE-1 22

LINE-182

LINE-1\&2

LINE-1\&2

LINE-1\&2

LINE-1\&2

LINE-1 \&2

LINE-1\&2

LINE-1\&2

LINE-182

LINE-1\&2

LINE-1\&2

LINE-1\&2

LINE-1\&2

LINE-1\&2

LINE-1\&2

LINE-1\&2

LINE-1\&2

LINE-1\&2

LINE-1\&2

LINE-1\&2

LINE-1\&2

LINE-1\&2

LINE-1\&2

LINE-1\&2

LINE-1\&2

LINE-1\&2

LINE-1\&2

LINE-1\&2

LINE-1\&2

LINE-1\&2

LINE-1\&2

LINE-1\&2

LINE-1\&2

LINE-1\&2

LINE-1\&2

LINE-1\&2

LINE-1\&2

LINE-1\&2

LINE-1\&2

LINE-1\&2
$540550386.312500 \quad 5154836.000000 \quad-122.342796$

$550 \quad 550683.875000 \quad 5154857.500000 \quad-122.338913$

$560 \quad 550982.312500 \quad 5154785.500000 \quad-122.335030$

$570 \quad 551270.312500 \quad 5154691.500000 \quad-122.331284$

$580 \quad 551568.375000 \quad 5154645.000000-122.327400$

$590 \quad 551856.187500 \quad 5154713.500000 \quad-122.323639$

$600552124.1250005154852 .000000-122.320129$

$610552381.3750005155002 .000000-122.316757$

$620552642.6250005155163 .000000-122.313332$

$630552905.1250005155312 .500000 \quad-122.309891$

$640553157.6250005155467 .500000-122.306580$

$650553419.5000005155622 .000000-122.303146$

$\begin{array}{lllll}660 & 553593.312500 & 5155815.000000 & -122.300858\end{array}$

$670553891.6875005155865 .500000 \quad-122.296959$

$680554194.6875005155855 .000000 \quad-122.293007$

$690554487.0000005155804 .000000 \quad-122.289200$

$700 \quad 554785.375000 \quad 5155734.500000 \quad-122.285316$

$\begin{array}{lllll}710 & 555062.875000 & 5155704.000000 & -122.281700\end{array}$

$\begin{array}{lllll}720 & 555339.812500 & 5155673.000000 & -122.278091\end{array}$

$\begin{array}{lllll}730 & 555628.375000 & 5155582.500000 & -122.274338\end{array}$

$740555910.8750005155461 .500000 \quad-122.270668$

$750556136.125000 \quad 5155274.500000 \quad-122.267754$

$760556363.1875005155067 .500000-122.264816$

$770556547.3750005154825 .000000-122.262444$

$780556728.0000005154588 .000000-122.260117$

$790556994.3125005154451 .500000 \quad-122.256660$

$800557251.5000005154290 .500000-122.253326$

$810557441.6250005154052 .500000 \quad-122.250877$

$820557631.6875005153811 .000000 \quad-122.248428$

$830557796.6875005153563 .000000 \quad-122.246307$

$840558037.687500 \quad 5153386.500000-122.243187$

$850558284.6250005153209 .000000-122.239990$

$860558495.5000005152997 .500000-122.237267$

$870558732.0000005152811 .500000-122.234207$

$880558988.375000 \quad 5152674.500000 \quad-122.230881$

$890559234.687500 \quad 5152508.500000 \quad-122.227692$

$900559440.5000005152291 .500000 \quad-122.225037$

$910 \quad 559707.375000 \quad 5152165.000000 \quad-122.221573$

$920559953.687500 \quad 5151998.500000 \quad-122.218384$

$930560118.3125005151745 .500000-122.216270$

$940560293.3125005151508 .500000-122.214020$

$950560478.3750005151266 .000000-122.211639$

$960560709.6875005151079 .000000-122.208649$

$970560997.187500 \quad 5151008.500000-122.204910$

$980561300.1250005150927 .500000-122.200974$

$990561567.8125005150797 .000000 \quad-122.197502$
46.547169

46.547340

46.546669

46.545799

46.545361

46.545952

46.547180

46.548512

46.549938

46.551262

46.552639

46.554008

46.555729

46.556160

46.556042

46.555561

46.554909

46.554611

46.554310

46.553471

46.552361

46.550659

46.548779

46.546581

46.544430

46.543179

46.541710

46.539551

46.537361

46.535118

46.533508

46.531891

46.529968

46.528271

46.527020

46.525501

46.523529

46.522369

46.520851

46.518559

46.516411

46.514210

46.512508

46.511848

46.511089

46.509892 
LINE-1 $\$ 2$

LINE-1\&2

LINE-1 \&2

LINE-1\&2

LINE-1\&2

LINE-1\&2

LINE-1\&2

LINE-1\&2

LINE-1 \&2

LINE-182

LINE-1 22

LINE-182

LINE-182

LINE-1\&2

LINE-1\&2

LINE-1\&2

LINE-1\&2

LINE-1\&2

LINE-1\&2

LINE-1\&2

LINE-1\&2

LINE-1\&2

LINE-1\&2

LINE-1\&2

LINE-1\&2

LINE-1\&2

LINE-1\&2

LINE-1\&2

LINE-182

LINE-1\&2

LINE-1\&2

LINE-1\&2

LINE-1\&2

LINE-1\&2

LINE-182

LINE-1\&2

LINE-1\&2

LINE-1\&2

LINE-1\&2

LINE-1\&2

LINE-1\&2

LINE-1 \&2

LINE-1\&2

LINE-1822

LINE-182

LINE-1\&2
$1000561845.1250005150756 .000000-122.193893$

$1010562132.8125005150847 .000000-122.190132$

$1020562441.0000005150867 .000000-122.186111$

$1030562729.1875005150857 .500000-122.182358$

$1040562995.8750005150988 .000000-122.178864$

$1050563227.5000005151181 .000000-122.175819$

$1060563484.3750005151346 .500000-122.172447$

$1070563751.1875005151473 .000000-122.168953$

$1080564018.5000005151604 .500000-122.165451$

$1090564285.6875005151736 .000000-122.161949$

$1100564547.3125005151857 .000000-122.158524$

$1110564825.6250005151988 .500000-122.154877$

$1120565061.3125005152164 .500000-122.151779$

$1130565298.1250005152357 .000000-122.148666$

$1140565523.687500 \quad 5152544.500000-122.145699$

$\begin{array}{lllll}1150 & 565785.875000 & 5152700.000000 & -122.142258\end{array}$

$1160566048.187500 \quad 5152852.500000 \quad-122.138817$

$1170566309.812500 \quad 5153008.000000 \quad-122.135384$

$1180566566.8750005153150 .000000 \quad-122.132011$

$1190566833.8125005153306 .500000-122.128510$

$1200567086.1250005153457 .000000-122.125198$

$1210567342.500000 \quad 5153604.000000 \quad-122.121834$

$1220567610.625000 \quad 5153755.000000 \quad-122.118317$

$1230567867.0000005153897 .000000-122.114952$

$1240568134.1875005154017 .500000-122.111450$

$1250568421.687500 \quad 5154104.500000-122.107689$

$1260568714.6250005154179 .500000-122.103859$

$1270568997.3750005154261 .000000-122.100159$

$1280569285.3750005154350 .500000-122.096390$

$1290569542.1875005154503 .000000-122.093018$

$1300569798.5000005154659 .000000-122.089653$

$1310570025.0000005154846 .000000-122.086670$

$\begin{array}{lllll}1320 & 570280.687500 & 5154996.000000 & -122.083313\end{array}$

$1330570537.5000005155146 .500000 \quad-122.079941$

$1340570814.6250005155260 .500000 \quad-122.076309$

$1350571117.3750005155285 .500000 \quad-122.072357$

$\begin{array}{llll}1360 & 571409.625000 & 5155211.500000 & -122.068558\end{array}$

$1370571696.3750005155145 .500000-122.064827$

$\begin{array}{lllll}1380 & 571993.875000 & 5155071.500000 & -122.060959\end{array}$

$1390572280.8750005154991 .500000 \quad-122.057228$

$1400572557.875000 \quad 5154916.000000 \quad-122.053627$

$1410572854.8750005154836 .000000 \quad-122.049767$

$1420573131.6250005154742 .000000-122.046173$

$1430573398.8750005154606 .000000-122.042709$

$1440573675.3750005154477 .000000-122.039124$

$1450573973.1250005154437 .500000 \quad-122.035248$
46.509499

46.510288

46.510441

46.510330

46.511478

46.513191

46.514660

46.515770

46.516930

46.518089

46.519150

46.520309

46.521870

46.523579

46.525242

46.526619

46.527962

46.529339

46.530590

46.531971

46.533298

46.534599

46.535931

46.537182

46.538239

46.538990

46.539639

46.540340

46.541119

46.542461

46.543839

46.545502

46.546822

46.548149

46.549149

46.549339

46.548641

46.548019

46.547321

46.546570

46.545860

46.545109

46.544231

46.542980

46.541790

46.541401 
$\begin{array}{llllll}\text { LINE-1\&2 } & 1460 & 574265.000000 & 5154396.500000 & -122.031448 & 46.541000\end{array}$

LINE-1\&2 $1470574567.3750005154357 .000000-122.027512$ 46.540611

LINE-1\&2 1480574854.187500 $5154297.000000-122.023781$

LINE-1\&2

LINE-1\&2

LINE-182

LINE-122

LINE-1\&2

LINE-1\&2

LINE-1\&2

1490575141.625000

$1500575433.6250005154192 .000000-122.016243$

$1510575731.6875005154172 .000000-122.012360$

$1520576018.8750005154082 .500000-122.008629$

46.540039

$1530576311.000000 \quad 5154027.500000-122.004829$

46.539509

46.539028

46.538818

46.537979

$1540576607.500000 \quad 5154082.500000-122.000954$

46.537449

$1550576874.500000 \quad 5154207.000000-121.997452$

46.537910

LINE-1 82

1560

$5154277.000000-121.993690$

46.539001

LINE-1\&2

LINE-1\&2

LINE-1\&2

LINE-1\&2

1570

577162.125000

46.539600

$1580577756.1875005154352 .500000-121.985931$

46.540058

$1590578043.8750005154272 .000000-121.982193$

46.540211

$1600578320.6250005154187 .500000-121.978600$

46.539452

LINE-1\&2

1604

$578439.1250005154167 .000000-121.977058$

46.538658

46.538460 


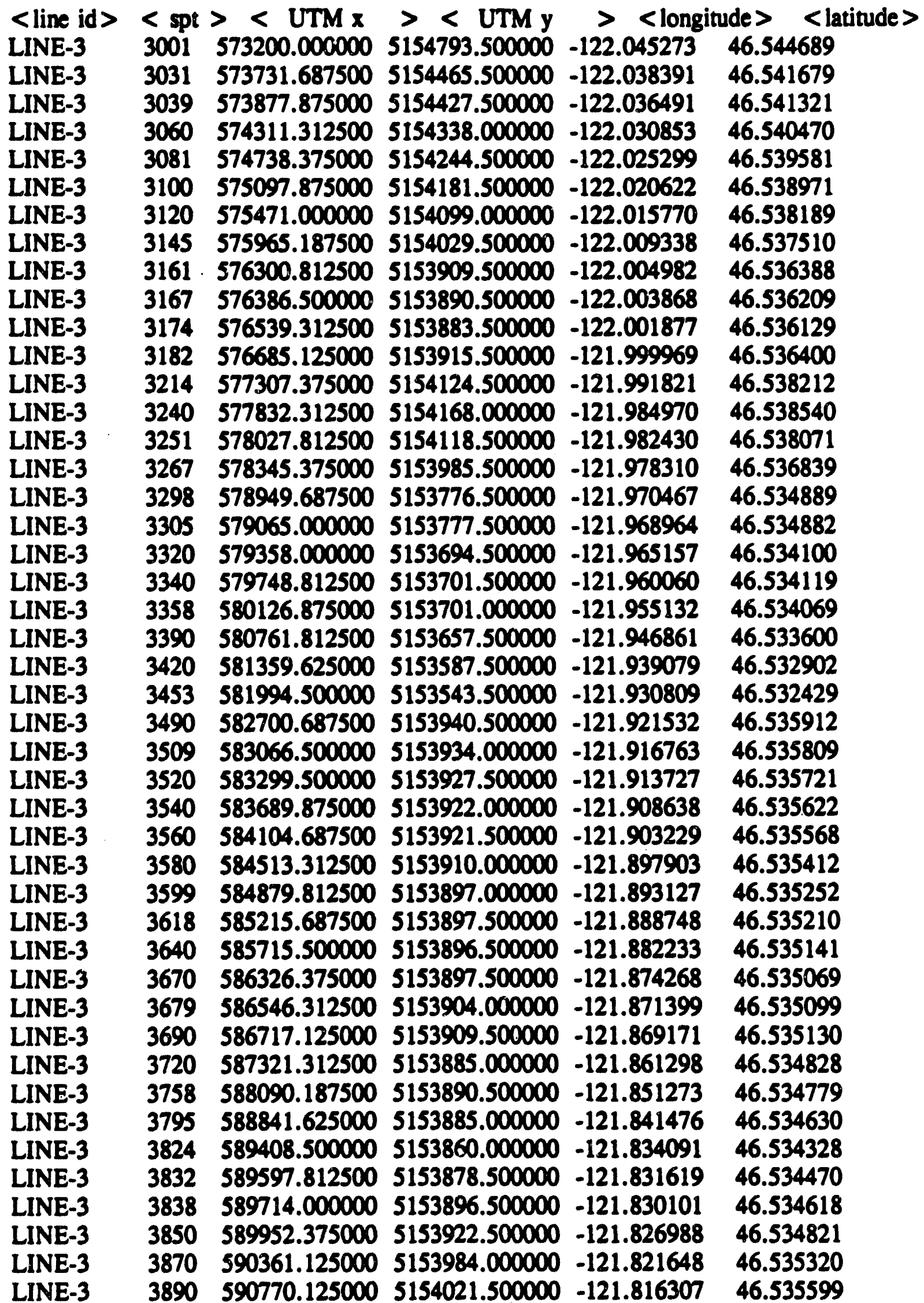




\begin{tabular}{|c|c|c|c|c|c|}
\hline $\begin{array}{l}\text { LINE-3 } \\
\text { LINE-3 }\end{array}$ & $\begin{array}{l}3913 \\
3917\end{array}$ & $\begin{array}{l}591227.187500 \\
59130050000\end{array}$ & 5154058.000000 & -121.810341 & $\begin{array}{l}46.535870 \\
46536 n 01\end{array}$ \\
\hline LINL-S & 3916 & 591300.500000 & 5154084.000000 & -121.809380 & 46.536091 \\
\hline LINE-3 & 3930 & 591563.375000 & 5154114.500000 & -121.805946 & 46.536331 \\
\hline LINE-3 & 3951 & 591978.187500 & 5154158.500000 & -121.800529 & 46.536671 \\
\hline LINE-3 & 3971 & 592381.187500 & 5154095.500000 & -121.795288 & 46.536049 \\
\hline LINE-3 & 3982 & 592594.875000 & 5154047.000000 & -121.792511 & 46.535580 \\
\hline LINE-3 & 4016 & 593272.687500 & 5153923.000000 & -121.783699 & 46.534370 \\
\hline INE-3 & 4025 & 593461.500000 & 5153897.500000 & -121.781242 & 46.534119 \\
\hline LINE-3 & 4044 & 593846.125000 & 5153928.500000 & -121.776222 & 46.534340 \\
\hline LINE-3 & 4054 & 594034.687500 & 5153884.500000 & -121.773773 & 46.533920 \\
\hline LINE-3 & 4076 & 594402.187500 & 5154298.000000 & -121.768898 & 46.537590 \\
\hline LINE-3 & 4080 & 594499.000000 & 5154316.000000 & -121.767632 & 46.537739 \\
\hline LINE-3 & 4109 & 595034.187500 & 154518.000000 & -121.760612 & 46.539478 \\
\hline LINE-3 & 4120 & 595235.000000 & 54626.500000 & -121.757973 & 46.540428 \\
\hline LINE-3 & 4130 & 595398.375000 & 5154761.500000 & -121.755814 & 46.541618 \\
\hline LINE-3 & 4148 & 595684.875000 & 500000 & -121.752029 & 46.543720 \\
\hline LINE-3 & 4155 & 595782.125000 & 5155103.500000 & -121.750740 & 46.544640 \\
\hline LINE-3 & 4170 & 596001.125000 & 5155317.000000 & -121.747841 & 46.546532 \\
\hline LINE-3 & 4193 & 596299.125000 & 5155671.000000 & -121.743881 & 46.549671 \\
\hline LINE-3 & 4205 & 596505.375000 & 5155829.500000 & -121.741158 & 46.551071 \\
\hline LINE-3 & 4236 & 596955.625000 & 5156213.500000 & -121.735207 & 46.554459 \\
\hline LINE-3 & 4250 & 597198.312500 & 56396.000000 & -121.732002 & 46.556068 \\
\hline LINE-3 & 4267 & 597465.875000 & 5156635.500000 & -121.728462 & 46.558182 \\
\hline LINE-3 & 4297 & 597928.500000 & 157007.000000 & -121.722351 & 46.561459 \\
\hline LINE-3 & 4315 & 598195.687500 & 5157226.000000 & -121.718819 & 46.563389 \\
\hline LINE-3 & 4331 & 598445.125000 & 5157428.000000 & -121.715523 & 46.565170 \\
\hline LINE-3 & 4360 & 598907.125000 & 5157788.000000 & -121.709419 & 46.568340 \\
\hline LINE-3 & 4383 & 599277.687500 & 5158087.500000 & -121.704521 & 46.570980 \\
\hline LINE-3 & 4394 & 599454.625000 & 5158209.000000 & -121.702187 & 46.572048 \\
\hline LINE-3 & 4424 & 599964.875000 & 5158612.000000 & -121.695442 & 46.575600 \\
\hline LINE-3 & 4445 & 600263.187500 & 5158856.000000 & -121.691498 & 46.577751 \\
\hline LINE-3 & 4457 & 600408.625000 & 5159044.000000 & -121.689560 & 46.579418 \\
\hline LINE-3 & 4464 & 600493.500000 & 5159179.000000 & -121.688423 & 46.580620 \\
\hline LINE-3 & 4475 & 600548.812500 & 5159367.500000 & -121.687660 & 46.582310 \\
\hline LINE-3 & 4481 & 600554.687500 & 5159509.000000 & -121.687553 & 46.583580 \\
\hline LINE-3 & 450 & 600518.125000 & 5159880.500000 & -121.687950 & 46.586929 \\
\hline LINE-3 & 4524 & 600506.125000 & 000 & -121.688004 & 46.591209 \\
\hline LINE-3 & 4530 & 600542.625000 & 5160479.000000 & -121.687500 & 46.592312 \\
\hline LINE-3 & 4546 & 600688.375000 & 5160784.000000 & -121.685532 & 46.595032 \\
\hline LINE-3 & 4554 & 600798.625000 & 5160905.500000 & -121.684067 & 46.596111 \\
\hline LINE & 458 & 601114.000000 & 161302.000000 & -121.679863 & 46.599628 \\
\hline LINE-3 & 460 & 601430.625000 & 61735.500000 & -121.675636 & 46.603481 \\
\hline LINE-3 & 462 & 601588.000000 & 162003.500000 & -121.673523 & 46.605869 \\
\hline LINE-3 & 4632 & 601735.000000 & 5162125.000000 & -121.671577 & 46.606941 \\
\hline LINE-3 & 4660 & 601935.625000 & 5162668.500000 & -121.668839 & 46.611801 \\
\hline LINE & 469 & 602184.187500 & $63273 \mathrm{mmm}$ & -121.665459 & 46.617199 \\
\hline
\end{tabular}




\begin{tabular}{|c|c|c|c|c|c|}
\hline $\begin{array}{l}\text { LINE-3 } \\
\text { LINE-3 }\end{array}$ & $\begin{array}{l}4710 \\
4713 \\
4778\end{array}$ & $\begin{array}{l}602300.000000 \\
602336.125000 \\
600182\end{array}$ & $\begin{array}{l}5163614.000000 \\
5163688.000000 \\
516301050000\end{array}$ & $\begin{array}{l}-121.663872 \\
-121.663383 \\
-121.661330\end{array}$ & $\begin{array}{l}46.620251 \\
46.620911 \\
46.620071\end{array}$ \\
\hline LINE-3 & 4743 & 602652.625000 & 5164182.500000 & -121.659142 & $\begin{array}{l}40.022811 \\
46.625309\end{array}$ \\
\hline LINE-3 & 4770 & 603072.187500 & 5164517.500000 & -121.653587 & 46.628262 \\
\hline LINE-3 & 4794 & 603461.625000 & 5164809.500000 & -121.648438 & 46.630829 \\
\hline LINE-3 & 4821 & 603868.187500 & 5165145.500000 & -121.643051 & 46.633789 \\
\hline LINE-3 & 4826 & 603965.687500 & 5165218.500000 & -121.641762 & 46.634430 \\
\hline LINE-3 & 4850 & 604 & 5165554.500000 & -121.637321 & \\
\hline LINE-3 & 4870 & 604 & 5920.000000 & -121.634613 & 10659 \\
\hline LINE-3 & 4877 & 604616.375000 & 5166030.000000 & -121.633080 & 46.641628 \\
\hline LINE-3 & 4900 & 87500 & 5166341.500000 & -121.628563 & 1379 \\
\hline LINE-3 & 4920 & 605515.3 & 5166057.000000 & -121.621330 & 1731 \\
\hline LINE-3 & 4940 & 605740.687500 & 5166266.500000 & -121.618340 & 46.643581 \\
\hline LINE-3 & 4954 & 605953. & 5166533.500000 & -121.615494 & 46.645950 \\
\hline INE-3 & 4962 & 605911.000000 & 5166975.000000 & -121.615952 & 46.649929 \\
\hline LINE-3 & 4965 & 886.500000 & 67000.000000 & -12 & \\
\hline LINE-3 & 4980 & 606245.687500 & 5167140.000000 & -121.611542 & 46.651 \\
\hline LINE-3 & 4994 & 606478.687500 & 5167304.500000 & -121.608459 & 46.652802 \\
\hline LINE-3 & 5016 & 606757.000000 & 5167682.500000 & -121.604736 & 46.656158 \\
\hline LINE-3 & 5028 & 606819.625000 & 5167903.000000 & -121.603867 & 1 \\
\hline LINE-3 & 5030 & 606819.187500 & 5167958.500000 & -121.603859 & 46. \\
\hline LINE-3 & 5051 & 606883.000000 & 5168378.500000 & -121.602928 & 46.662399 \\
\hline LINE-3 & 5079 & 607254.625000 & 5168824.500000 & -121.597969 & 00035 \\
\hline LINE-3 & 5097 & 607387.312500 & 516914 & -121.596161 & \\
\hline LINE-3 & 5113 & 607627.187500 & 5169373.000000 & -121.592972 & 46.671230 \\
\hline LINE-3 & 5133 & 608005.500000 & 5169502.000000 & -121.587997 & 46.672 \\
\hline LINE-3 & 5154 & 608321.000000 & 5169782.500000 & -121.583809 & 46.674801 \\
\hline LINE-3 & 5168 & 608598.687500 & 5169916.500000 & -121.580147 & 75 \\
\hline LINE-3 & 5177 & 608718.125000 & 5170063.000000 & -121.578552 & 677 \\
\hline LINE-3 & 5189 & 608787.875000 & 5170301.000000 & -121.577583 & 670 \\
\hline LINE-3 & 5195 & 608825.875000 & 5170429.500000 & -121.577057 & 46.680 \\
\hline LINE-3 & 5209 & 608901.812500 & 5170716.500000 & -121.575996 & 46.68310 \\
\hline LINE & 5218 & 608907.687500 & 5170874.500000 & -121.575882 & \\
\hline LINE. & 5219 & 608908.187500 & 5170911.500000 & -121.575867 & \\
\hline LINE-3 & 5232 & 608661.812500 & 5171112.500000 & -121.579041 & 40.080110 \\
\hline
\end{tabular}




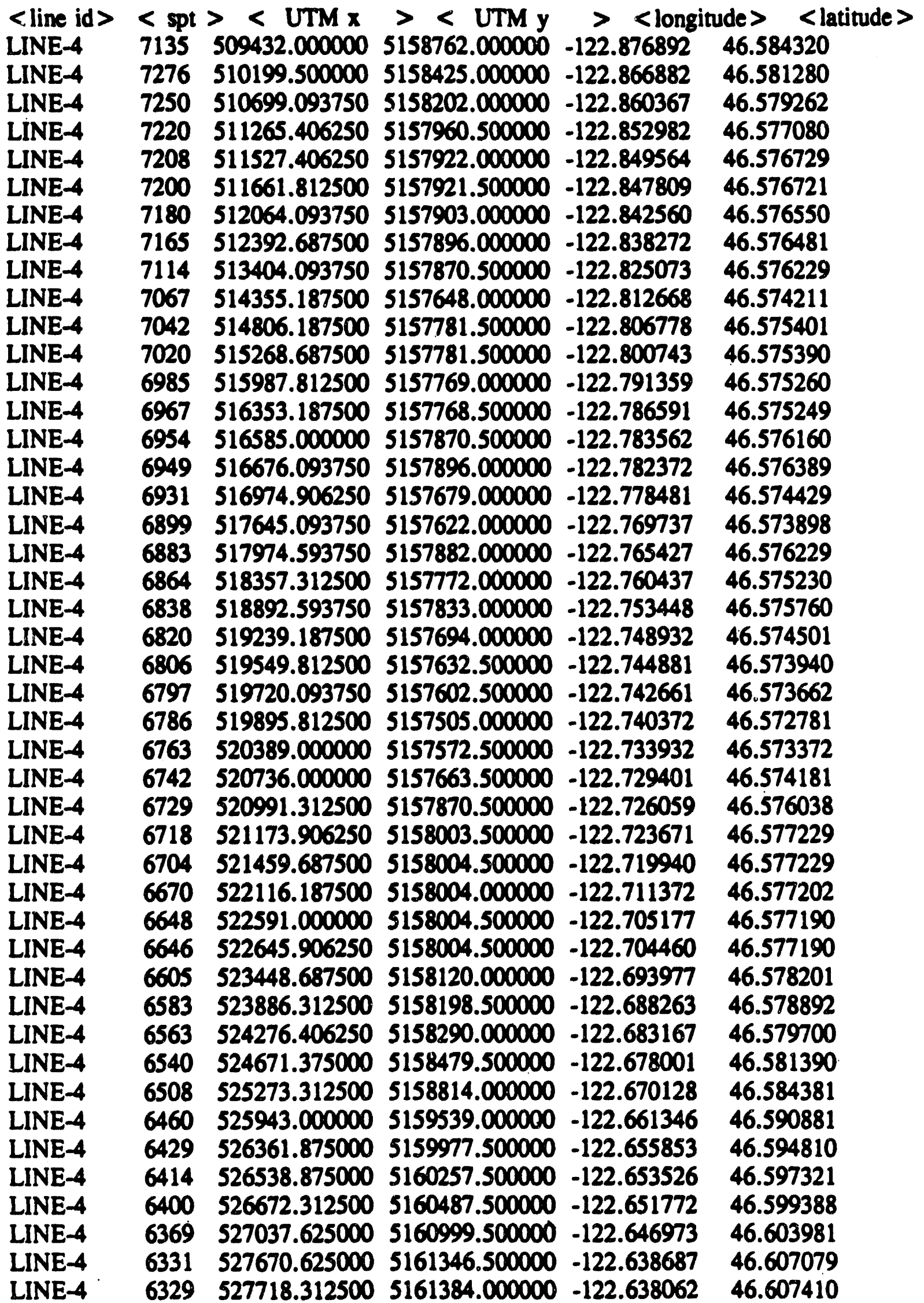




\begin{tabular}{|c|c|c|c|c|c|}
\hline $\begin{array}{l}\text { LINE-4 } \\
\text { LINE-4 }\end{array}$ & 6320 & $\begin{array}{l}527858.625000 \\
528046.875000\end{array}$ & $\begin{array}{l}5161505.500000 \\
5161718.500000\end{array}$ & $\begin{array}{l}-122.636223 \\
-122.633751\end{array}$ & $\begin{array}{l}46.608501 \\
46.610409\end{array}$ \\
\hline LINE-4 & 6284 & 528357.375000 & 5162036.000000 & -122.629677 & 46.613251 \\
\hline LINE-4 & 6266 & 528698.375000 & 5162084.000000 & -122.625221 & 46.613670 \\
\hline LINE-4 & 6250 & 529008.625000 & 5162078.000000 & -122.621170 & 3602 \\
\hline LINE-4 & 6230 & 529415.812500 & 5162077.500000 & -122.615852 & 46.613579 \\
\hline LINE-4 & 6200 & 530110.687500 & 5162154.000000 & -122.606773 & 46.614239 \\
\hline LINE-4 & 6173 & 530652.875000 & 5162141.500000 & -122.599693 & 46.614101 \\
\hline LINE-4 & 6167 & 530762.687500 & 5162142.000000 & -122.598259 & 46.614101 \\
\hline LINE-4 & 6143 & 531257.000000 & 5162243.500000 & -122.591797 & 46.614990 \\
\hline LINE-4 & 6129 & 531549.312500 & 5162211.500000 & -122.587982 & 46.614689 \\
\hline LINE-4 & 6111 & 531884.500000 & 5162129.000000 & -122.583611 & 46.613930 \\
\hline LINE-4 & 6090 & 250.687500 & 5161924.000000 & -122.578842 & 46.612068 \\
\hline LINE-4 & 6067 & 532665.187500 & 5161669.500000 & -122.573448 & 46.609760 \\
\hline LINE-4 & 6056 & 532847.875000 & 5161592.500000 & -122.571068 & 46.609058 \\
\hline LINE-4 & 6009 & 533780.375000 & 5161599.000000 & -122.558891 & 46.609070 \\
\hline LINE-4 & 5984 & 534274.687500 & 5161388.500000 & -122.552452 & 46.607151 \\
\hline INE-4 & 5954 & 534865.687500 & 5161337.500000 & -122.544739 & 46.606659 \\
\hline LINE-4 & 5939 & 535140.125000 & 5161287.000000 & -122.541161 & 46.606190 \\
\hline LINE-4 & 5931 & 535335.375000 & 5161261.500000 & -122.538612 & 46.605949 \\
\hline LINE-4 & 5922 & 535493.500000 & 5161203.500000 & -122.536552 & 46.605419 \\
\hline LINE-4 & 5890 & 536152.625000 & 000 & -122.527946 & 46.605331 \\
\hline LINE-4 & 5852 & 536896.000000 & 5161184.000000 & -122.518242 & 46.605171 \\
\hline LINE-4 & 5810 & 537743.187500 & 61184.500000 & -122.507179 & 46.605129 \\
\hline LINE-4 & 5771 & 538542.125000 & 5161165.500000 & -122.496750 & 04912 \\
\hline LINE-4 & 5766 & 538633.312500 & 5161166.000000 & -122.495560 & 46.604912 \\
\hline LINE-4 & 5754 & 538871.687500 & 5161165.000000 & -122.492447 & 46.604889 \\
\hline LINE-4 & 5741 & 539102.812500 & 5161038.000000 & -122.489441 & 46.603729 \\
\hline LINE-4 & 5724 & 539419.875000 & 5160891.000000 & -122.485313 & 46.602390 \\
\hline LINE-4 & 5714 & 9578.000000 & 5160833.000000 & -122.483253 & 46.601860 \\
\hline LINE-4 & 5695 & 539949.812500 & 5160903.500000 & -122.478394 & 46.602470 \\
\hline LINE-4 & 5676 & 10273.625000 & 5160981.000000 & -122.474159 & 46.603149 \\
\hline LINE-4 & 5670 & 540383.375000 & 5161158.500000 & -122.472710 & 46.604740 \\
\hline LINE-4 & 5665 & 540365.125000 & 5161274.000000 & -122.472939 & 46.605782 \\
\hline LINE-4 & 5654 & 540487.125000 & 5161376.000000 & -122.471336 & 46.606689 \\
\hline LINE-4 & 5639 & 540664.000000 & 5161140.500000 & -122.469048 & 46.604561 \\
\hline LINE-4 & 5629 & 540810.312500 & 5161019.000000 & -122.467148 & 46.603458 \\
\hline LINE-4 & & 540980.500000 & 5161005.500000 & -122.464928 & .603329 \\
\hline LINE-4 & 5616 & 541053.875000 & 5161032.000000 & -122.463966 & 46.603561 \\
\hline LINE-4 & 5607 & 541260.812500 & 5161114.500000 & -122.461258 & 504290 \\
\hline LINE-4 & 5600 & 541382.500000 & 5161088.500000 & -122.459671 & 604050 \\
\hline LINE-4 & & 541644.875000 & 5161006.000000 & -122.456253 & 603291 \\
\hline LINE-4 & 5582 & 541706.125000 & 5161032.000000 & -122.455452 & 46.603519 \\
\hline LINE-4 & & 542041.187500 & 5161076.500000 & -122.451073 & 46.603901 \\
\hline LINE-4 & 5556 & 542286.625000 & 5161413.000000 & -122.44783 & \\
\hline LINE-4 & 5537 & 542639.000000 & 5161238.500000 & -122.443253 & 46.605320 \\
\hline
\end{tabular}




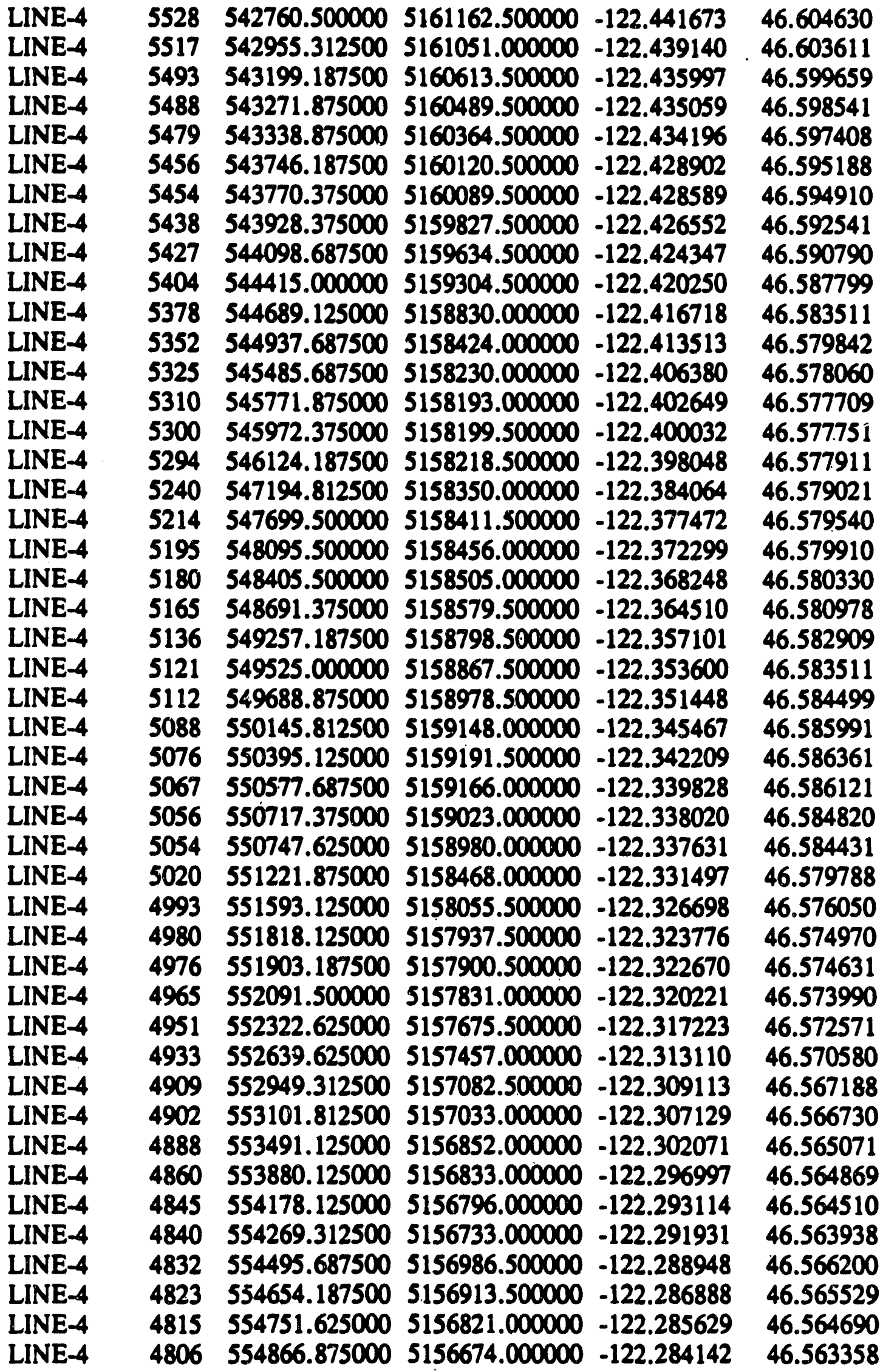




\begin{tabular}{|c|c|c|c|c|c|}
\hline LINE-4 & 4803 & 554891.375000 & 5156625.500000 & -122.283829 & 46.562920 \\
\hline LINE-4 & 4800 & 554940.687500 & 5156600.500000 & -122.283188 & .562691 \\
\hline LINE-4 & 4792 & 555044.187500 & 5156661.500000 & -122.281830 & 46.563229 \\
\hline LINE-4 & 4782 & 555269.375000 & 5156594.500000 & -122.278900 & 46.562611 \\
\hline LINE-4 & 4772 & 555409.312500 & 5156649.500000 & -122.277069 & 46.563091 \\
\hline LINE-4 & 4769 & 555482.875000 & 5156650.000000 & -122.276108 & 46.563091 \\
\hline LINE-4 & 4757 & 555683.812500 & 5156557.500000 & -122.273499 & 46.562241 \\
\hline LINE-4 & 4749 & 555763.312500 & 5156435.000000 & -122.272476 & 46.561131 \\
\hline LINE-4 & 4744 & 75000 & 5156374.500000 & -122.271530 & 46.560581 \\
\hline LINE-4 & 4733 & 87500 & 5156331.000000 & -122.270187 & 560181 \\
\hline LINE-4 & 4720 & 12500 & 5156177.000000 & -122.265678 & 46.558769 \\
\hline LINE-4 & 4710 & & 5156104.500000 & -122.263542 & 46.558102 \\
\hline LINE-4 & 4687 & & 55871.500000 & -122.258400 & 46.555969 \\
\hline LINE-4 & 4669 & 12500 & 155637.500000 & -122.254623 & 53841 \\
\hline LINE-4 & 4654 & .187500 & 5155594.500000 & -122.250809 & 46.553429 \\
\hline LINE-4 & 4638 & 557742.687500 & 5155484.500000 & -122.246773 & 46.552410 \\
\hline LINE-4 & 4623 & & 00.000000 & -122.243530 & 0732 \\
\hline LINE-4 & 4610 & 687500 & 5155129.000000 & -122.241638 & 46.549179 \\
\hline LINE-4 & 4580 & 812500 & 767.500000 & -122.234940 & 45879 \\
\hline LINE-4 & 4565 & 0000 & .500000 & -122.232903 & 46.543598 \\
\hline LINE-4 & 4557 & .125000 & 5154393.000000 & -122.231880 & 42488 \\
\hline LINE-4 & 4528 & .812500 & 5153871.500000 & -122.227737 & 46.537769 \\
\hline LINE-4 & 4518 & 187500 & 12.500000 & -122.226410 & 46.536331 \\
\hline LINE-4 & 4500 & $0 / 4.8 / 5000$ & 5153620.500000 & -122.221809 & 46.535469 \\
\hline LINE-4 & 4485 & 5 & .000000 & -122.219299 & 3630 \\
\hline LINE-4 & 4480 & 559918.312500 & 5153331.500000 & -122.218674 & 46.532848 \\
\hline LINE-4 & 4460 & 0186.687500 & 5152994.500000 & -122.215218 & 46.529789 \\
\hline LINE-4 & 4451 & se & .500000 & -122.214996 & 46.528412 \\
\hline NE-4 & 4441 & 560150.187500 & 5152657.500000 & -122.215736 & 46.526760 \\
\hline LINE-4 & 4433 & 5 & 0000 & -122.215523 & 46.525379 \\
\hline LINE-4 & 4423 & 560321.000000 & 5152376.000000 & -122.213547 & 46.524212 \\
\hline LINE-4 & 4418 & 14.000000 & 5152252.500000 & -122.213654 & 46.523102 \\
\hline LINE-4 & 4400 & 5603 & 51891.500000 & -122.213463 & 46.519852 \\
\hline LINE-4 & 4389 & 0289.875000 & 5151682.000000 & -122.214043 & 46.517971 \\
\hline LINE-4 & 4386 & 560277 & 5151615.000000 & -122.214211 & 46.517368 \\
\hline LINE-4 & 4380 & 560339.187500 & 5151548.000000 & -122.213417 & 46.516762 \\
\hline LINE-4 & 4370 & 56 & 5151369.000000 & -122.211777 & 15141 \\
\hline LINE-4 & 4364 & 560533.31 & 1272.000000 & -122.210922 & 46.514259 \\
\hline LINE-4 & 4355 & 56 & 51149.000000 & -122.209099 & 46.513142 \\
\hline LINE-4 & 4350 & $0765012 \mathrm{~cm}$ & 1088.0000 & -122.207916 & 46.512581 \\
\hline LINE-4 & 4340 & $560954.31250 \mathrm{C}$ & 5151033.000000 & -122.205467 & 46.51207 \\
\hline LINE-4 & 4330 & & 0000 & -122.202690 & 46.511662 \\
\hline LINE-4 & 4302 & 561661.125000 & 5150768.500000 & -122.196289 & 46.509628 \\
\hline LINE-4 & 4297 & & 0756.5000 & -122.195023 & 46.509510 \\
\hline LINE-4 & 4292 & 561856.1875 & 5150756.500000 & -122.193748 & 46.509499 \\
\hline LINE-4 & 4280 & 562087.812500 & 5150836.500000 & -122.190720 & 46.510201 \\
\hline
\end{tabular}




$\begin{array}{lllllll}\text { LINE-4 } & 4276 & 562148.875000 & 5150873.000000 & -122.189919 & 46.510521 \\ \text { LINE-4 } & 4267 & 562356.000000 & 5150879.500000 & -122.187218 & 46.510559 \\ \text { LINE-4 } & 4265 & 562367.500000 & 5150848.500000 & -122.187073 & 46.510281 \\ \text { LINE-4 } & 4263 & 562380.125000 & 5150817.000000 & -122.186913 & 46.509998 \\ \text { LINE-4 } & 4258 & 562441.125000 & 5150744.500000 & -122.186127 & 46.509338 \\ \text { LINE-4 } & 4251 & 562557.125000 & 5150799.000000 & -122.184608 & 46.509819 \\ \text { LINE-4 } & 4245 & 562672.125000 & 5150769.500000 & -122.183113 & 46.509541 \\ \text { LINE-4 } & 4233 & 562800.312500 & 5150541.500000 & -122.181473 & 46.507481 \\ \text { LINE-4 } & 4212 & 562897.875000 & 5150168.000000 & -122.180252 & 46.504108 \\ \text { LINE-4 } & 4210 & 562934.687500 & 5150118.500000 & -122.179779 & 46.503658 \\ \text { LINE-4 } & 4180 & 563099.000000 & 5149518.000000 & -122.177719 & 46.498241 \\ \text { LINE-4 } & 4164 & 563166.375000 & 5149236.500000 & -122.176880 & 46.495701 \\ \text { LINE-4 } & 4146 & 563026.000000 & 5148880.500000 & -122.178757 & 46.492512 \\ \text { LINE-4 } & 4130 & 562824.812500 & 5148635.000000 & -122.181412 & 46.490318 \\ \text { LINE-4 } & 4116 & 562696.875000 & 5148377.000000 & -122.183113 & 46.488010 \\ \text { LINE-4 } & 4111 & 562721.187500 & 5148285.000000 & -122.182808 & 46.487179 \\ \text { LINE-4 } & 4104 & 562837.187500 & 5148168.000000 & -122.181313 & 46.486118 \\ \text { LINE-4 } & 4095 & 563001.687500 & 5148119.000000 & -122.179176 & 46.485661 \\ \text { LINE-4 } & 4084 & 563154.500000 & 5147959.500000 & -122.177208 & 46.484211 \\ \text { LINE-4 } & 4077 & 563288.375000 & 5147923.000000 & -122.175468 & 46.483871 \\ \text { LINE-4 } & 4069 & 563428.000000 & 5147850.000000 & -122.173660 & 46.483200 \\ \text { LINE-4 } & 4050 & 563805.875000 & 5147837.500000 & -122.168739 & 46.483051 \\ \text { LINE-4 } & 4045 & 563915.625000 & 5147813.000000 & -122.167313 & 46.482819 \\ \text { LINE-4 } & 4037 & 564000.375000 & 5147715.000000 & -122.166222 & 46.481930 \\ \text { LINE-4 } & 4033 & 564037.500000 & 5147640.500000 & -122.165749 & 46.481258 \\ \text { LINE-4 } & 4027 & 564080.500000 & 5147512.500000 & -122.165207 & 46.480099 \\ \text { LINE-4 } & 4018 & 564202.000000 & 5147371.500000 & -122.163643 & 46.478821 \\ \text { LINE-4 } & 4012 & 564256.875000 & 5147279.000000 & -122.162941 & 46.477982 \\ \text { LINE-4 } & 4001 & 564244.625000 & 5147052.000000 & -122.163132 & 46.475941\end{array}$


<line id > $<\mathrm{spt}>\langle$ UTM x > UTM y > <longitude> <latitude> LINE-5

LINE-5

LINE-5

LINE-5 $-1 \quad 544885.500000 \quad 5153789.500000-122.414642$ $961544924.687500 \quad 5153784.000000-122.414131$

LINE-5 $992 \quad 545540.6250005153884 .500000-122.406090$ $1001 \quad 545724.000000 \quad 5153847.000000-122.403702$

LINE-S

LINE-5

1011

545891.687500

$5153731.500000-122.401527$

1025

$546150.312500 \quad 5153579.000000-122.398170$

1046

$546592.875000 \quad 5153389.000000-122.392418$

LINE-S

1085

LINE-5

LINE-5

1089

LINE-5

1108

547395.812500

$5153362.000000-122.381950$

$547492.1875005153388 .500000-122.380692$

LINE-5

1110

547858.125000

$5153575.500000-122.375900$

LINE-S

1161

547915.187500

$5153612.500000-122.375153$

1171

LINE-5

548768.812500

$5154264.000000-122.363953$

1176

LINE-5

LINE-5

LINE-5

1185

1220

1228

LINE-5

1250

LINE-5

1253

LINE-5

1255

LINE-5

1260

LINE-5

1279

LINE-5

LINE-5

1313

1330

LINE-5

1334

LINE-5

1348

LINE-5

1380

LINE-5

LINE-5

LINE-5

LINE-5

548948.187500

$5154364.500000-122.361603$

$549057.8750005154396 .000000-122.360168$

$549226.1250005154438 .000000-122.357971$

$549985.0000005154344 .000000-122.348083$

$550145.812500 \quad 5154425.500000-122.345978$

$550521.3750005154702 .000000-122.341049$

$550566.187500 \quad 5154733.500000-122.340462$

$550604.625000 \quad 5154758.000000-122.339958$

$550687.875000 \quad 5154802.000000-122.338867$

$551102.375000 \quad 5154895.500000-122.333450$

$551810.875000 \quad 5154748.000000-122.324226$

$552163.375000 \quad 5154709.000000-122.319633$

$552248.687500 \quad 5154724.500000-122.318520$

$552558.5000005154814 .500000-122.314468$

1415

$553160.3750005155152 .500000-122.306580$

$553698.1875005155457 .000000-122.299530$

1436

$554204.687500 \quad 5155719.500000-122.292892$

1456

$554613.3750005155800 .500000-122.287552$

1464

$554834.187500 \quad 5155836.000000-122.284668$

LINE-5

1473

554983.187500 5155852.000000 -122.282.722

LINE-5

1495

$555428.8750005155787 .000000-122.276917$

LINE-5

1513

LINE-5

LINE-5

LINE-5

LINE-5

LINE-5

LINE-5

LINE-5

LINE-5

LINE-5

LINE-5

1520

$554840.125000 \quad 5155700.500000-122.284607$

1529

$554969.1875005155715 .500000-122.282921$

$54980.6250005155745 .000000-122.282768$

$\begin{array}{llll}-3 & 555393.625000 & 5155740.000000 & -122.277382\end{array}$

$\begin{array}{lllll}1578 & 556107.687500 & 5155748.000000 & -122.268066\end{array}$

$\begin{array}{lllll}-1 & 556105.312500 & 5155813.500000 & -122.268089\end{array}$

$\begin{array}{lllll}-1 & 556590.687500 & 5155952.500000 & -122.261742\end{array}$

$\begin{array}{llll}1606 & 554970.375000 & 5156295.500000 & -122.282837\end{array}$

$1614554960.5000005156413 .000000-122.282951$

46.538139

46.538090

46.538952

46.538601

46.537552

46.536160

46.534420

46.534119

46.534351

46.536011

46.536339

46.542141

46.543030

46.543308

46.543671

46.542770

46.543491

46.545952

46.546230

46.546452

46.546841

46.547649

46.546268

46.545891

46.546021

46.546810

46.549801

46.552502

46.554821

46.555519

46.555820

46.555950

46.555328

46.554600

46.554722

46.554989

46.554909

46.554920

46.555511

46.556721

46.559940

46.561001

46.561710

46.562168

46.562729 


\begin{tabular}{|c|c|c|c|c|c|}
\hline LINE-5 & 1642 & 555427.000000 & 5156634.000000 & -122.276840 & 46.562950 \\
\hline LINE-5 & 1647 & 555482.000000 & 5156564.500000 & -122.276131 & 46.562321 \\
\hline LINE-S & 1658 & 555677.625000 & 5156535.000000 & -122.273582 & 46.562038 \\
\hline LINE-5 & 1690 & 555991.812500 & 5157089.500000 & -122.269417 & 46.567001 \\
\hline LINE-S & 1727 & 556346.312500 & 5157702.500000 & -122.264717 & 46.572491 \\
\hline LINE-5 & 1730 & 556391.500000 & 5157739.500000 & -122.264122 & 46.572819 \\
\hline LINE-5 & 1734 & 556455.500000 & 5157771.500000 & -122.263283 & 46.573101 \\
\hline LINE-5 & 1738 & 556544.375000 & 5157767.500000 & -122.262123 & 46.573059 \\
\hline LINE-5 & 1749 & 556739.375000 & 5157744.000000 & -122.259583 & 46.572830 \\
\hline LINE-5 & 1756 & 556880.312500 & 5157806.500000 & -122.257736 & 46.573380 \\
\hline LINE-S & 1770 & 556966.812500 & 5158058.500000 & -122.256577 & 46.575642 \\
\hline LINE-5 & 1773 & 557001.625000 & 158088.500000 & -122.256119 & 46.575909 \\
\hline LINE-5 & 1775 & 557030.500000 & 5158119.000000 & -122.255737 & 46.576180 \\
\hline LINE-5 & 1790 & 557316.000000 & 5158223.000000 & -122.251999 & 46.577091 \\
\hline LINE-5 & 1801 & 557464.625000 & 5158398.500000 & -122.250038 & 46.578659 \\
\hline LINE-5 & 1814 & 557516.625000 & 5158648.000000 & -122.249329 & 46.580898 \\
\hline LINE-5 & 1852 & 557904.375000 & 5159304.000000 & -122.244186 & 46.586769 \\
\hline LINE-5 & 1869 & 073.000000 & $\$ 581.000000$ & -122.241951 & 46.589249 \\
\hline LINE-5 & 1896 & 558307.375000 & 5160061.500000 & -122.238831 & 46.593552 \\
\hline LINE-5 & 1930 & 558668.000000 & 5160664.000000 & -122.234047 & 6.598942 \\
\hline LINE-5 & 1932 & 558690.625000 & 5160688.500000 & -122.233749 & 46.599159 \\
\hline LINE-5 & 1946 & 558759.187500 & 5160962.500000 & -122.232819 & 46.601620 \\
\hline LINE-5 & 1978 & 558824.500000 & 5161580.000000 & -122.231888 & 46.607170 \\
\hline LINE-5 & 2008 & 558971.687500 & 5162182.500000 & -122.229889 & 46.612579 \\
\hline LINE-S & 2038 & 559108.687500 & 5162755.500000 & -122.228027 & 46.617722 \\
\hline LINE-5 & 2053 & & & -122.228249 & 20209 \\
\hline LINE-5 & 2058 & 559133.000000 & 5163134.500000 & -122.227661 & 46.621132 \\
\hline LINE-5 & 2064 & 559201.812500 & 5163207.500000 & -122.226753 & 46.621780 \\
\hline LINE-5 & 2067 & 559259.875000 & 5163238.000000 & -122.225990 & 46.622051 \\
\hline LINE-S & 2082 & & 63423.000000 & -122.222649 & 46.623692 \\
\hline LINE-5 & 2092 & 559695.687500 & 5163470.000000 & -122.220268 & 46.624100 \\
\hline LINE-5 & 2098 & 559806.375000 & 5163509.000000 & -122.218819 & 46.624439 \\
\hline LINE-5 & 2110 & 560015.375000 & 5163639.000000 & -122.216072 & 46.625591 \\
\hline LINE-5 & 2122 & 560067.375000 & 5163865.000000 & -122.215363 & 46.627621 \\
\hline LINE-5 & 2136 & 560232.125000 & 5164106.500000 & -122.213181 & 46.629780 \\
\hline LINE-5 & 2144 & 0358.312500 & 5164216.5 & -122.211517 & 46.630760 \\
\hline LINE-5 & 2151 & 560407.812500 & 5164348.000000 & -122.210854 & 46.631939 \\
\hline LINE-5 & 2172 & 560447.687500 & 5164800.000000 & -122.210274 & .636002 \\
\hline IJINE-5 & 2175 & 560458.312500 & 5164847.500000 & -122.210129 & 46.636429 \\
\hline INE-5 & 2200 & 966.000000 & 5165309.500000 & -122.216499 & 46.640629 \\
\hline LINE-5 & 2216 & 0080.812500 & 5165628.500000 & -122.214958 & 46.643490 \\
\hline LINE-S & 2224 & 560146.500000 & 5165779.500000 & -122.214081 & $\$ 6.644840$ \\
\hline LINE-5 & 2248 & 560517.000000 & 5166156.500000 & -122.209190 & 46.648201 \\
\hline LINE-S & 2250 & 560544.000000 & 5166198.500000 & -122.208832 & 46.648579 \\
\hline LINE & 2277 & 560758.375000 & 166712.000000 & -122.205963 & 46.653179 \\
\hline LINE & 2297 & 560800.875000 & 5167128.500000 & -122.205353 & 46.656921 \\
\hline
\end{tabular}




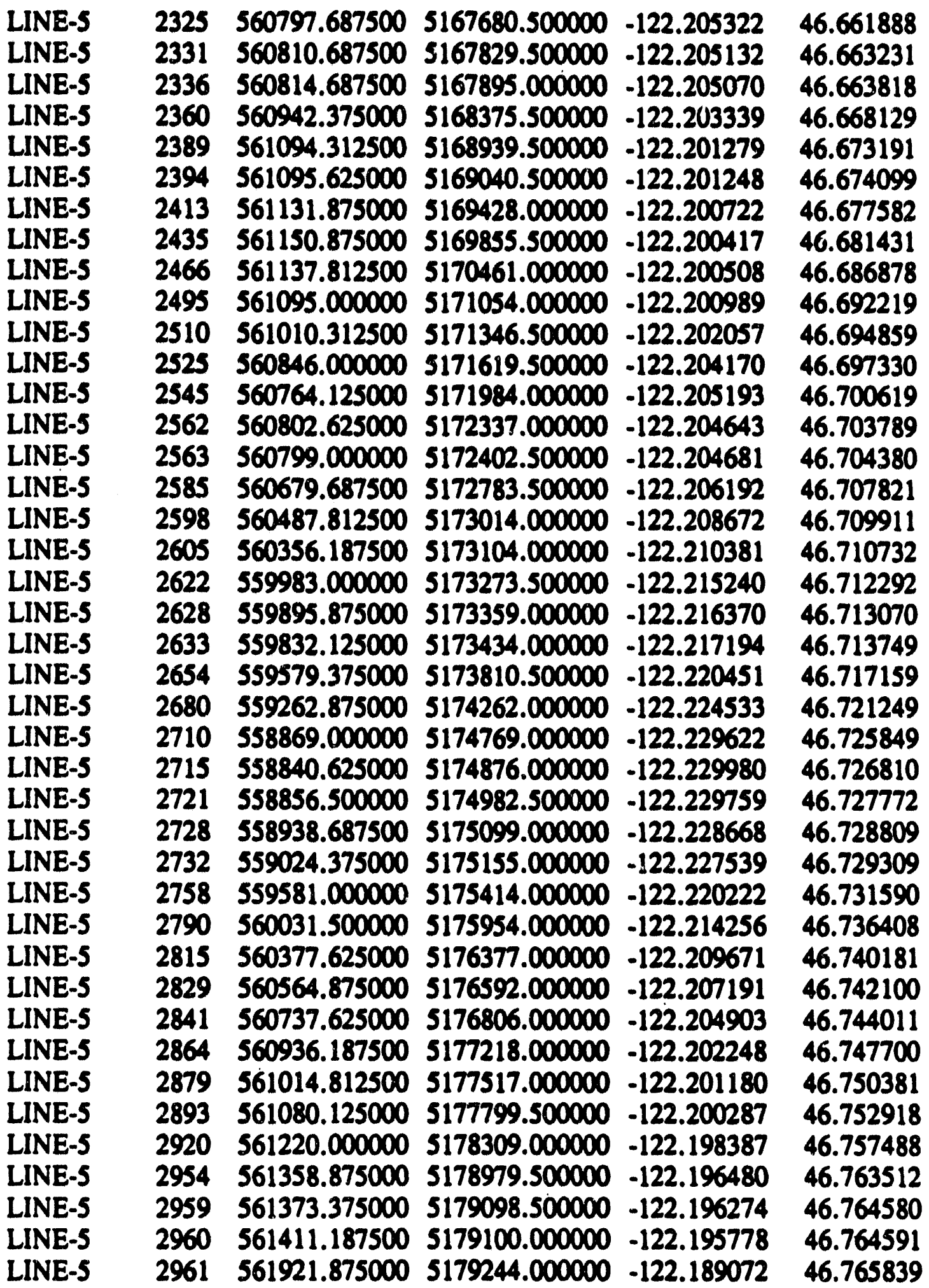




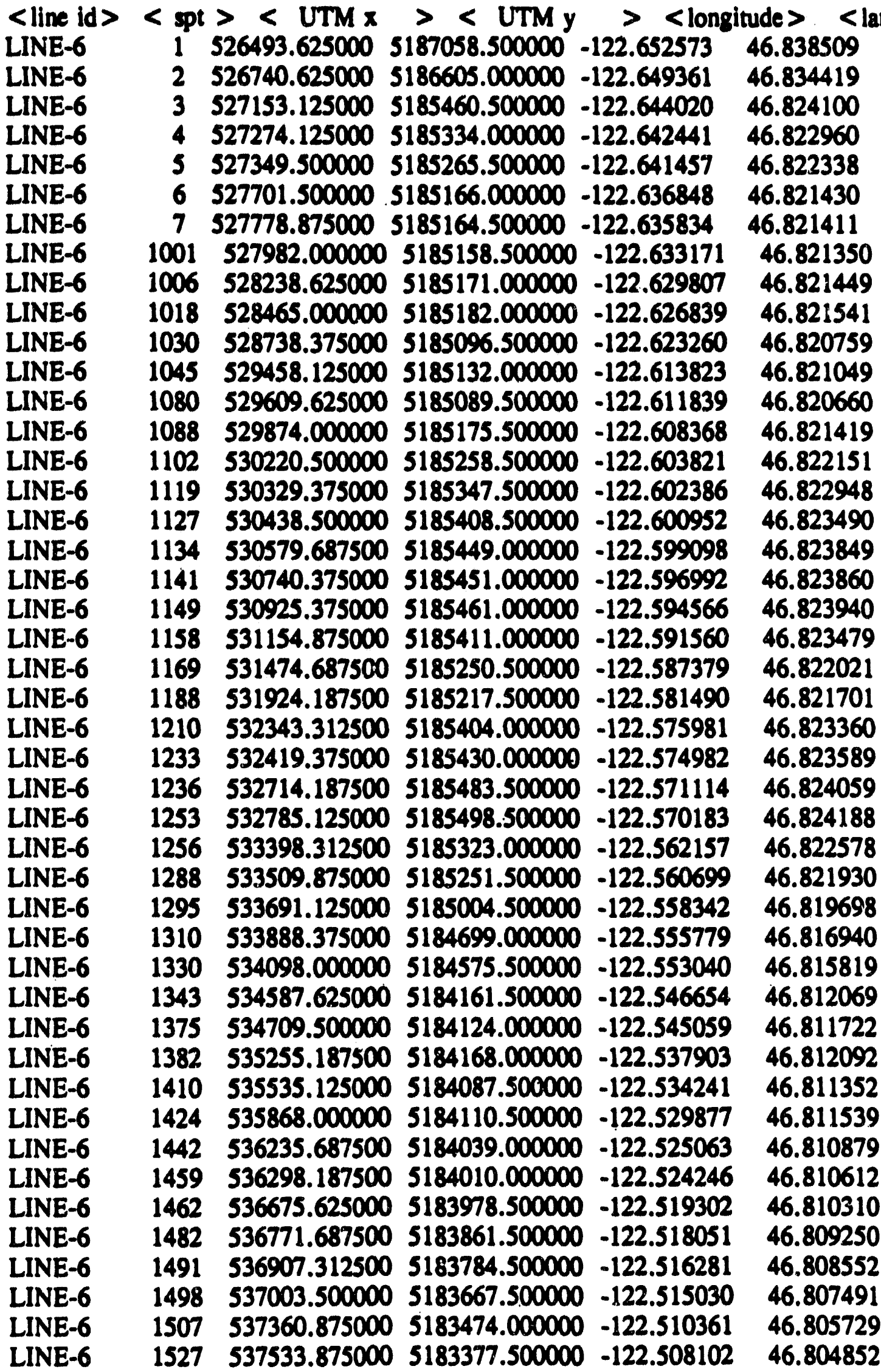




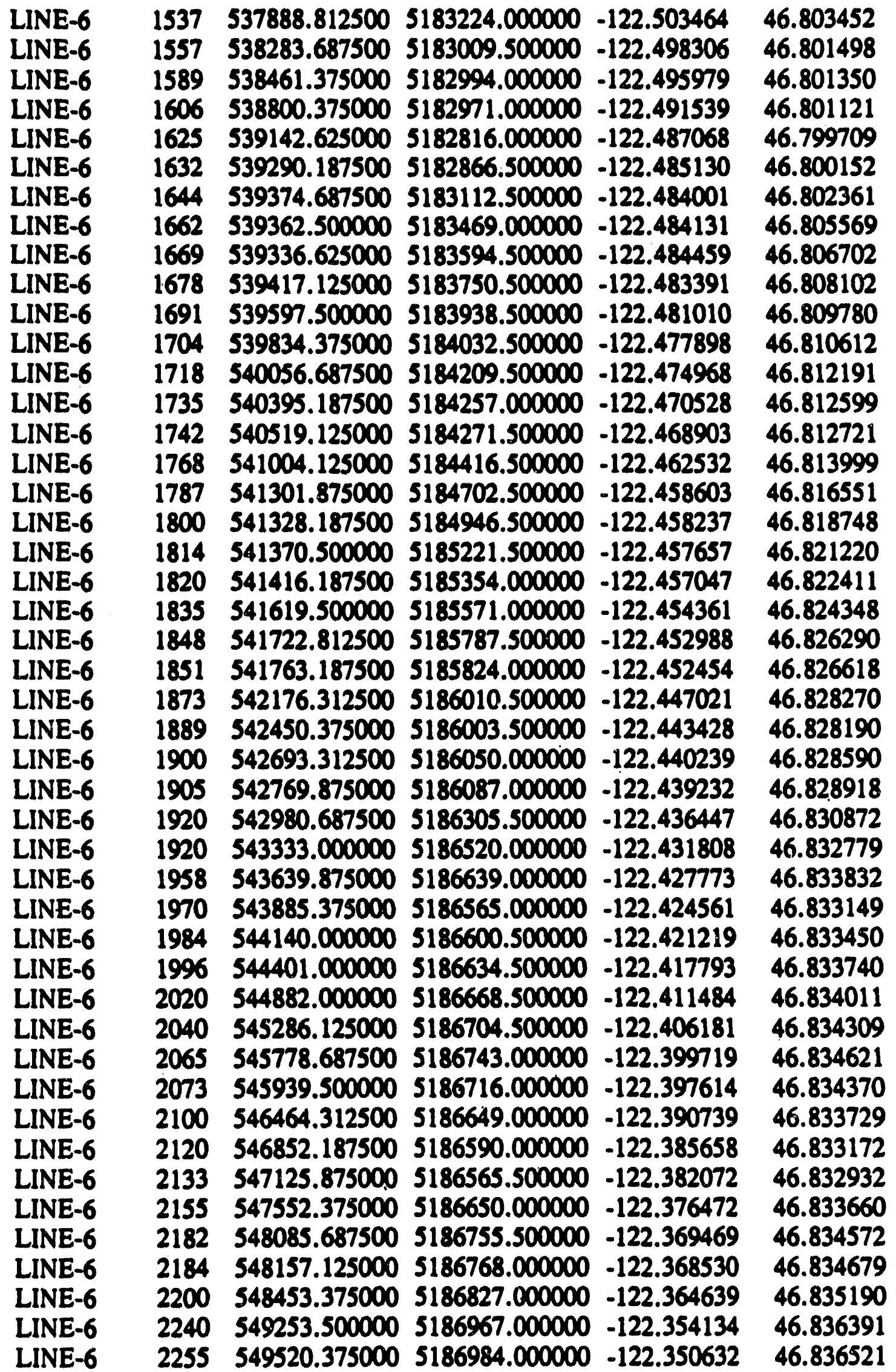




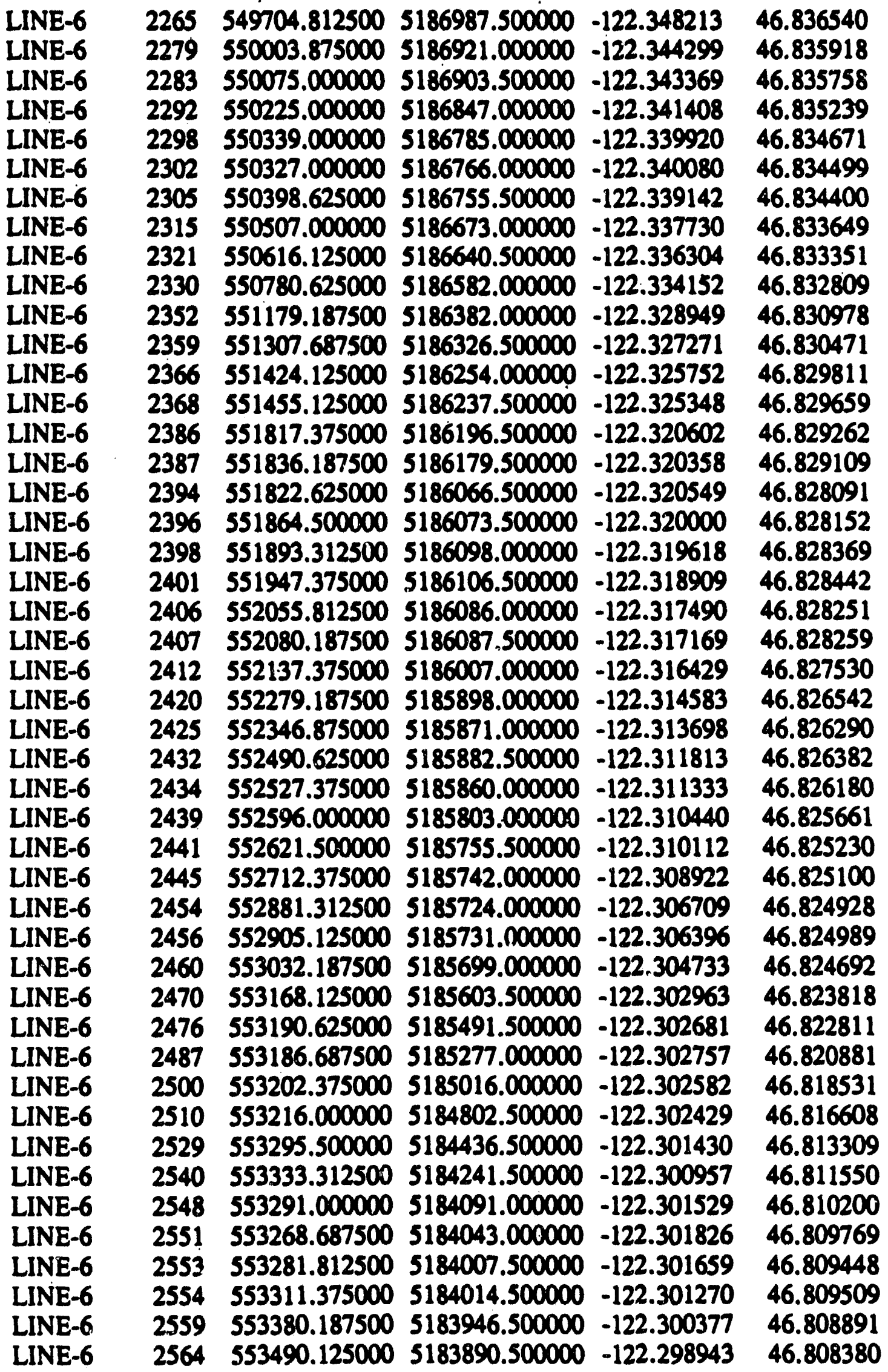




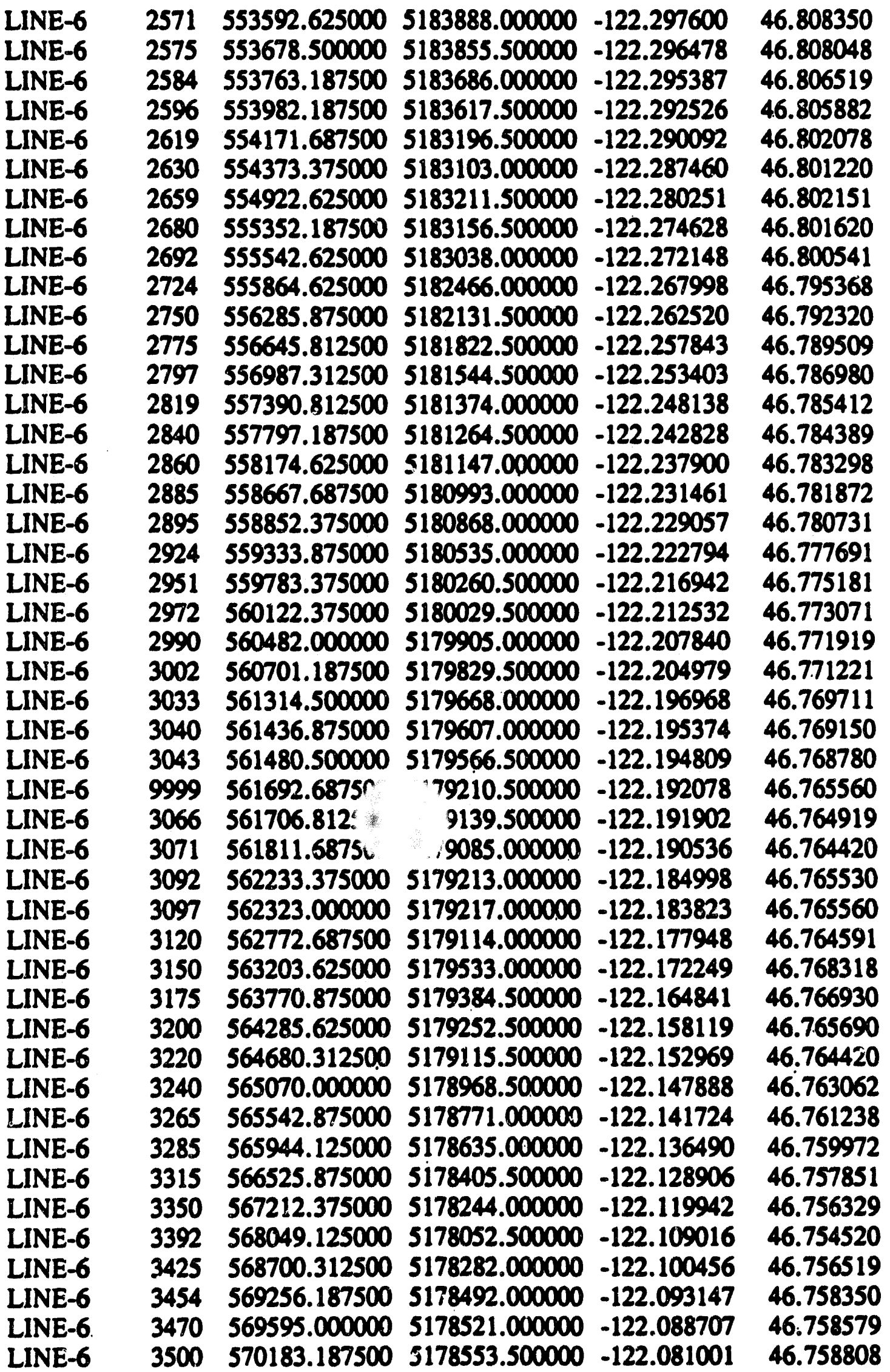


$\begin{array}{lllllll}\text { LINE-6 } & 3525 & 570676.875000 & 5178589.500000 & -122.074532 & 46.759079\end{array}$

$\begin{array}{lllllll}\text { LINE-6 } & 3550 & 571170.812500 & 5178609.000000 & -122.068062 & 46.759201\end{array}$

$\begin{array}{llllll}\text { LINE-6 } & -1 & 571391.125000 & 5178608.000000 & -122.065178 & 46.759171\end{array}$ 
Appendix C

\section{MT AND SEISMIC-REFLECTION DATA AND PHYSICAL PROPERTIES}

\section{Physical Properties}

The ability to interpret lithology from the MT and seismic data sets is dependent upon our understanding of the electrical and acoustic properties of rocks under the temperatures and pressures encountered in the Cascade Range and surrounding region. The following, short discussion of rock properties is included to provide a background for statements concerning lithological correlations of various MT and seismic models in this paper.

Electrical resistivity vary over an extremely large dynamic range, with common rock resistivities typically ranging from 1 to $10,000 \mathrm{ohm}-\mathrm{m}$. Rock-forming minerals are normally very resistive at surface pressures and temperatures, with the exception of metallic minerals and graphitic carbon, which are very low in resistivity. For most rocks, resistivity is controlled by ionic conduction through fluids in pore spaces or intergranular coatings, rather than electronic conduction through the mineral matrix. This ionic-controlled resistivity is a function of salinity of the pore fluids, temperature, and pressure, and is important for sedimentary and other rocks with connected porosities of greater than fow tenths of a percent. Ionic mobility increases and resistivity decreases as temperature is increased, but the effect on resistivity reaches a maximum at temperatures around $200-250^{\circ} \mathrm{C}$ for depths of a few $\mathrm{km}$.

As porous rocks are buried to depths greater than a few $\mathrm{km}$, porosities are decreased due to lithostatic loading until the rocks normally become highly resistive. In shales, ionic conduction also occurs in trapped water in clays and zeolites; as a result, the resistivity of shales will be low $(1-20 \mathrm{ohm}-\mathrm{m})$ and varies less than other sedimentary rocks as porosity decreases. As shales are metamorphosed, both porosity and layered clays are destroyed, but low resistivities can be maintained due to formation of carbonaceous or iron mineral films along fissile planes in the metashales. Intrusive rocks have very low porosity and thus are normally very resistive, typically in the range of $500-20,000 \mathrm{ohm}-\mathrm{m}$. Fracture porosity and intense alteration of intrusive rocks can lower their resistivity well below this range. Unaltered volcanic rocks have very high resistivities when pore waters are very fresh; however, es volcanic rocks increase in age, development of authigenic minerals (clays and zeolites) dramatically decreases their resistivity. Typical values for tuffaceous-rich (non-welded tuff and ash alters very fast) flows and volcaniclastic rocks of Tertiary age in the Oregon Cascades are less than $20 \mathrm{ohm}-\mathrm{m}$. Metamorphism of crustal rocks beyond zeolite facies generally increases resistivities, except for metamorphosed shales in which carbonaceous and/or metallic-mineral coatings may develop. Another exception to high resistivities in metamorphic rocks occurs upon dehydration of greenschist or amphibolite facies minerals in the rocks, as demonstrated by Lee and others (1983); their laboratory measurements on high-grade metamorphic rocks at temperatures up to $300^{\circ} \mathrm{C}$ and pressures of $0.4 \mathrm{GPa}$ indicated lowered resistivities that they attributed to high-pore-pressure fluids from mineral dehydration. As temperature and pressure increases, partial melting may occur, leading to a decrease in resistivity of the rocks by up to two orders of magnitude if there is sufficient interconnection 
between intergranular melt films.

Accuracies in the MT models are. influenced largely by data quality, selection of strike direction, frequency-independent shifts of curves due to near-surface complexities (similar to weathering problems in seismic reflection surveys; Sternberg and others, 1989/ and oversimplified model geometry.

Seismic compressional-wave velocities in crustal rocks vary. over a much narrower range than do resistivities, typically ranging from $2-7.4 \mathrm{~km} / \mathrm{s}$. Velocities for Tertiary sedimentary rocks are typically $3-5 \mathrm{~km} / \mathrm{s}$. Compressional velocities for Cascades volcanic rocks range from $4-6 \mathrm{~km} / \mathrm{s}$, controlled by porosity, weathering, and proportion of mafic minerals. The velocity of intrusive rocks is influenced by the proportion of mafic to quartz minerals in the rocks, with felsic rocks such as granite having velocities of about $5-6 \mathrm{~km} / \mathrm{s}$ and intermediate to mafic intrusive rocks ranging higher than $6.3 \mathrm{~km} / \mathrm{s}$. Approximate velocities for the formations of interest to our study determined from sonic logs, stacking velocities, and analogy with similar geologic units. The recording of reflections from geologic formations is dependent upon sufficient acoustic contrast and favorable geometry of the reflecting surfaces (Anstey, 1977).

The seismic reflection data outlines two key pieces of structural information: (1) folding corresponding to mapped anticlines and synclines and (2) basal dipping reflectors on the west and east ends of. a long profile through the study area. Migration of the reflection data has only been done for the western part of this long profile because poor data quality for much of the profile did not warrant migration of the whole data set. Interpretation of unmigrated data will not affect general structural analyses for the anticlinal structures, but use of unmigrated data for the dipping reflectors on the west and east ends of the profile had to be handled cautiously. Because no wells were available along the reflection profiles, velocity information from wells in the nearby Chehalis basin, in combination with stacking velocities and empiral curves were used to aid processing and interpretation of the data. Approximate depth conversions used in the subsequent discussions and figures assume average velocities of $5 \mathrm{~km} / \mathrm{s}$. 


\section{Appendix D}

\section{Detalls of The Magnetotelluric Method}

MT data consist of measurements of the orthogonal components of time-varying. surface magnetic fields and their associated electric fields. These fields occur naturally as a result of electromagnetic induction in the Earth from magnetic variations originating in the ionosphere and atmosphere. In our surveys, horizontal electric fields were sensed using an L-shaped, 3-electrode array with dipole lengths of $37.5 \mathrm{~m}$. The orthogonal, horizontal magnetic fields in the direction of the electric-field measurement array were sensed using permalloy-cored induction coils (Stanley and Tinkler, 1983 ). The vertical magnetic field was measured only at selected sounding sites when a ringcore fluxgate magnetometer (Acuna, 1973) was deployed for magnetic field sampling instead of the induction coils. Time-series recordings of the electrical and magnetic field data were acquired using a computer-controlled data-acquisition system, with the computer and other electronics powered by marine storage batteries. The acquisition system used an analog signal-conditioning system for pre-whitening of the input spectrum and post-amplification, combined with a 12-bit analog-to-digital convertor. Data were recorded to disk for pass-bands at the three frequency ranges of $2-300 \mathrm{~Hz}$, 0.05-3 Hz, and 0.002-0.2 Hz. The measurements spanned a period of about 2-3 hours and included 3 to 6 recordings of the higher frequency bands and 1-4 recordings of the lowest frequency band. At selected sounding sites, the ring-core fluxgate magnetometer was used instead of the induction coils for magnetic field measurement to obtain vertical magnetic field data and to extend the MT data to frequencies of $.0002 \mathrm{~Hz}$ lone decade lower than that obtainable with the three standard bands above). An automated, battery-powered, data-acquisition system designed by $\mathbf{V}$. $F$. Labson, U.S.G.S. (pers. comm., 1989) was used with the ring-core magnetometer system and associated electric field sensors (identical to that used for the three standard bands). The automated system was deployed for at least 9 hours to record the lower frequency data .

The time-series data were converted to complex cross-spectra using FFT (FastFourier-transform) techniques. Least-squares, cross-spectral analysis (Bendat and Piersol, 1971) were used to solve for a tensor transfer function relating the observed electric fields to the magnetic fields, under the assumption that the Earth consists of a two-input, two-output linear system with the magnetic fields as input and the electric field as outputs:

$$
Z_{\mathbf{j}}=E_{1}+H_{1}
$$

Where $Z_{1}$ is the impedance tensor, $E_{1}$ are the two horizontal electric fields, and $H_{1}$

the two horizontal magnetic fields. 
When the vertical magnetic field was measured, the vertical field transfer function (or "ipper") was solved for, with the assumption that the vertical field is the output of a two -input, one-output system (with the vertical field as the output):

$$
H_{z}=A H_{x}+B H_{y}
$$

Where $H_{x}$ and $H_{y}$ are the horizontal magnetic fields, $H_{z}$ is the vertical magnetic field, and $A$ and $B$ are the transfer function elements.

The impedance tensor, $Z_{\mu}$ is treated as amplitude and phase quantitites. The amplitude of the tensor is converted to "apparent resistivities" using the relationship between the resistivity of a homogeneous earth to the tensor impedance relationship

$$
\rho_{a}=\frac{1}{\omega \mu_{0}}\left[\frac{E_{1}}{H_{j}}\right]^{2}
$$

between surface electric and magnetic fields:

Where $E_{1}$ and $H_{1}$ are the orthogonal electric and magnetic field pairs, $w$ is the radian frequency, and $\mu_{0}$ is the magnetic permeability lassumed to be the same as free space at MT frequencies).

The phase of the impedance tensor is given by the arctangent of the amplitude of the real part of the tensor to the imaginary part:

$$
\phi=\arctan \frac{z_{0}}{z_{8}}
$$

The measured resistivity and phase values are plotted versus frequency for computer modeling. Both the resistivity and phase data are normally used in the modeling, although it can be dernonstrated that they are not independent through the Hilbert transform (Bendat and Piersol, 1971). Prior to conversion to resistivity and phase, the tensor is normally rotated into principal directions that usually correspond to the direction of maximum and minimum resistivity. For a two-dimensional (2-D) earth the MT fields can be decoupled into transverse electric (TE) and transverse magnetic (TM) modes; two-dimensional modeling is generally done to fit both modes. When the geology satisfies the 2-D assumption, the MT data for the TE mode is assumed to represent the situation when the electric field is along the geologic strike and the TM mode for the electric field across strike. A measure of the correctness of the 2D assumption for MT data is provided by the skew of the impedance tensor, defined as the ratio of the magnitude of the diagonal elements over the off-diagonal elements (Vozoff, 1972). If the geology is truly 2D, then the skew will be zero. Remote or local reference sensors can be used to help reduce bias in the impedance determinations due to instrument or environmental noise [Gamble and others, 1979; Clark and others, 1983]. Although reference techniques were not used in our survey, 
we did sort cross-power files to select optimal signal-to-noise data sets.

Man-made electrical noise, such as powerlines and irrigation pumps can have a negative effect on MT data quality. In the survey area, there are numerous small powerlines that did not affect data quality as long as the soundings were done about $0.4 \mathrm{~km}$ distance from them. Large sprinkler systems driving by electric irrigation pumps were more of a problem and were not approached closer than 1 mile for soundings. Local lightning, wind and rainstorms can also degrade data quality, but these can be generally avoided by planning surveys to miss the most active thunderstorm periods. The MT signals that originate in the ionisphere and from equatorial lightning belts vary in spectral densities (amplitudes) from several factors. The lower frequency ionispheric signals $(.0001$ to $1 \mathrm{~Hz})$ are related to sunspor activity and the last three years have been ores of high sunspot activity and good signal levels, but even in low sunspot activity, the MT signals are adequate for year-round MT surveys. Higher frequency MT signals $(1 \mathrm{~Hz}$ to $10,000 \mathrm{~Hz}$ ) generated largely from equatorial lightning storms that propagates in the earth-ionispheric waveguide have minimums in amplitude in the northern hemisphere winter; this amplitude minimum does cause problerns with some wintertime MT surveys using the higher frequency ranges. An exceilent introduction to the MT method and references for a more advanced understanding are contained in Dobrin and Savit (1988). 

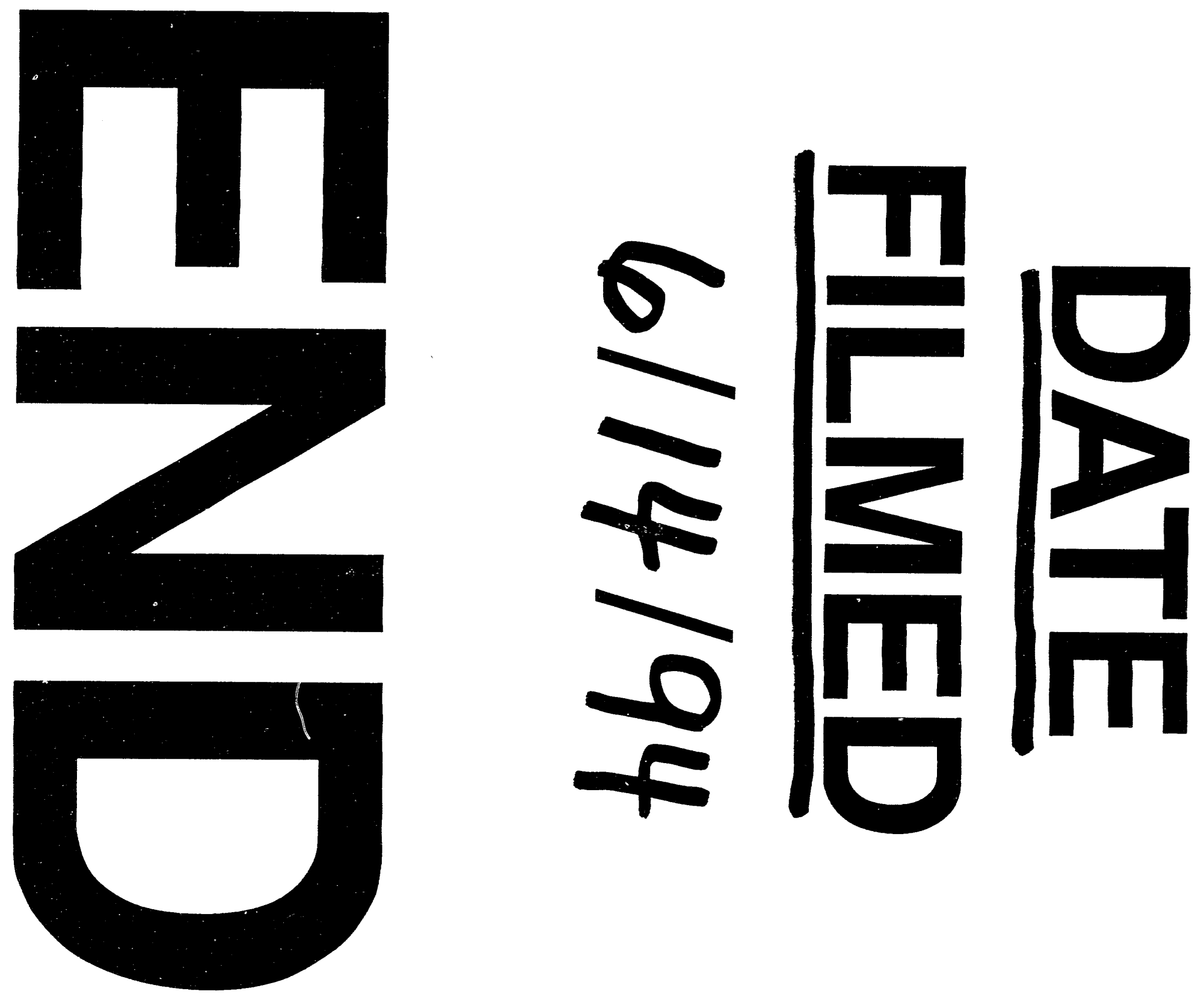
